PAULO DE TARSO BILARD DE CARVALHO

\title{
O CONCEITO JURÍDICO DO PRINCÍPIO DE IMPESSOALIDADE NO DIREITO ADMINISTRATIVO BRASILEIRO: UMA RELEITURA
}

\author{
DisSertação de Mestrado
}

Orientadora: Profa. Dra. Maria Sylvia Zanella Di Pietro

Faculdade de Direito da Universidade de São Paulo - USP São Paulo 


\title{
O CONCEITO JURÍDICO DO PRINCÍPIO DE IMPESSOALIDADE NO DIREITO ADMINISTRATIVO BRASILEIRO: UMA RELEITURA
}

\author{
Dissertação de mestrado apresentada \\ como requisito parcial para a conclusão \\ do curso de Mestrado em Direito, Área \\ Direito do Estado, Subárea Direito \\ Administrativo, sob orientação da \\ Profa. Dra. Maria Sylvia Zanella Di \\ Pietro.
}

Faculdade de Direito da Universidade de SÃo PaUlo - USP SÃo PAULO 2014 


\section{O CONCEITO JURÍDICO DO PRINCÍPIO DE IMPESSOALIDADE NO DIREITO ADMINISTRATIVO BRASILEIRO: UMA RELEITURA}

em de de 2014 . 


\section{Agradecimentos}

À professora Maria Sylvia Zanella Di Pietro, pela oportunidade da experiência acadêmica. À minha mãe, interlocutora universal!

À querida Raquel e à insondável Mariana: convívio inestimável.

Aos caros amigos Gustavo Dall'Olio, Luis Manuel Fonseca Pires, Cândido Alexandre Munhoz Perez e Carlos Eduardo Reis de Oliveira, cujo auxílio e companhia fraternos fizeram com que chegássemos até aqui.

A todos que, direta ou indiretamente, me auxiliam e me inspiram todos os dias. 


\section{RESUMO}

Esta tese trata do princípio de impessoalidade expresso no art. 37, caput, da Constituição da República de 1988. Parte-se da ideia de que toda construção jurídica pressupõe uma concepção de mundo. Mesmo passados 25 anos da outorga da Constituição, a doutrina não revela consenso sobre o significado jurídico deste princípio. A partir desta realidade, busca-se investigar para saber se o princípio existe, qual sua razão de ser, para quê ele serve, como ele se dá e, por fim, o que é, afinal, este princípio. Parte-se da premissa de que o léxico tem contribuído para a falta de consenso. O termo impessoal faz confundir o ser impessoal com o agir de modo impessoal, conforme parece dizer o dispositivo constitucional. Após algumas considerações sobre o contexto constitucional - que inverte o ponto de referência para o ser humano -, sobre o Direito Administrativo - dados históricos, características etc. -, faz-se uma pesquisa bibliográfica para saber o que pensam os autores que escreveram sobre ele. Em seguida, após o exame dos termos impessoal e impessoalidade e algumas considerações sobre a visão de intérpretes da experiência administrativa do Brasil, chegamos ao que parece significar o princípio de impessoalidade: uma nova concepção de mundo para a função administrativa - a processualidade e o controle finalísticos. 


\section{RÉSUMÉ}

Cette thèse porte sur le principe d'impersonnalité exprimé à l'article 37, caput, la Constitution de la République en 1988. Il commence avec l'idée que toute construction juridique présuppose une conception du monde. Même après 25 ans de l'octroi de la Constitution, la doctrine ne révèle pas un consensus sur la portée juridique de ce principe. De cette réalité, qui cherchent à mener une enquête afin de déterminer si le principe est là, quelle est votre raison d'être, pour qui il sert, comme il est et, enfin, ce qui est, après tout, ce principe. L'hypothèse que le lexique a contribué à l'absence de consensus. Le terme impersonnel fait confondre l'être impersonnel avec l'actuar impersonnellement, comme semble dire la disposition constitutionnelle. Après quelques considérations concernant le contexte constitutionnel - qui inverse le point de référence pour être humain -, sur le Droit administratif - les données historiques, les caractéristiques, etc. -, c'est une recherche bibliographique pour découvrir ce qu'ils pensent les auteurs qui ont écrit sur lui. Puis, après l'examen des termes impersonnel et impersonnalité et certaines considérations au sujet de la vision d'interprètes de l'expérience administrative du Brésil, nous sommes arrivés ce qui semble signifier le principe d'impersonnalité: une nouvelle conception du monde pour la fonction administrative - la processualité et le contrôle finalistiques. 


\section{SUMÁRIO}

APRESENTAÇÃ

I - INTRODUÇÃ O .................................................................................................................... 15

II - CONSIDERAÇÕES SOBRE A CONSTITUIÇÃO DA REPÚBLICA DE 1988.. 27

2. 1. Uma premissa antropológica do direito compatível com a Constituição vigente........27

2. 2. Uma noção de Estado compatível com a ordem constitucional vigente ...................... 28

2. 3. A Constituição da República e o processo de constitucionalização ............................ 32

2. 4. A Constituição de 1988: Estado Democrático de Direito e a sociedade ..................... 35

2.4.1. Ainda sobre o Estado Democrático: a complexidade do princípio democrático .......40

2.5. A Administração Pública na Constituição de 1988 ........................................................ 41

2.5.1. A Administração Pública como um dos integrantes da relação política..................... 45

2.6. A novidade constitucional do princípio de impessoalidade ............................................ 46

III - CONSIDERAÇÕES SOBRE O DIREITO ADMINISTRATIVO ........................51

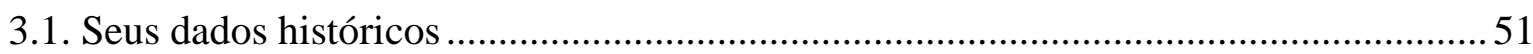

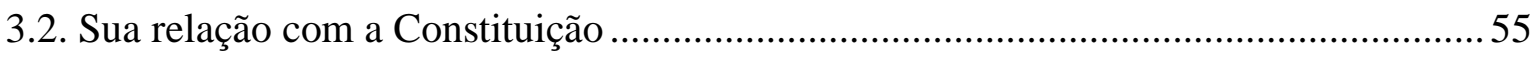

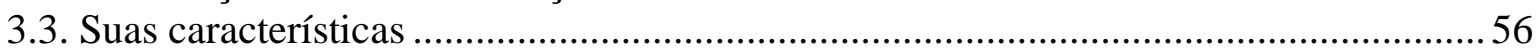

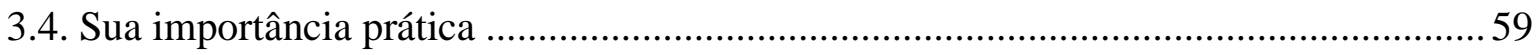

3.5. Sua função ontem e nos dias atuais: três visões de mundo......................................... 62

\section{IV - O PRINCÍPIO DE IMPESSOALIDADE NA DOUTRINA BRASILEIRA ........64}

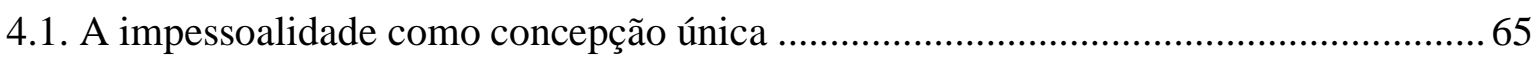

4.1.1. A impessoalidade como finalidade (ou interesse público) ......................................65

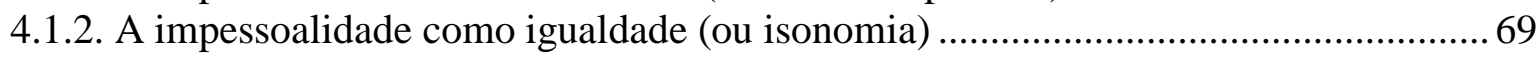

4.1.3. A impessoalidade como imparcialidade ................................................................ 71

4.1.3.1. A influência europeia para a concepção do princípio de imparcialidade ............... 76

4.2. A impessoalidade mesclada: concepções dúplices ou múltiplas ...................................77

4.2.1. A impessoalidade como finalidade e imputação......................................................... 77

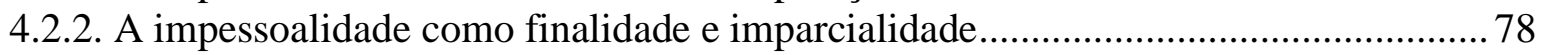

4.2.3. A impessoalidade como igualdade e legalidade ................................................. 79

4.2.4. A impessoalidade como isonomia e finalidade...................................................... 79

4.2.5. A impessoalidade como imparcialidade e objetividade .......................................... 81

4.2.6. A impessoalidade como imputação e objetividade .................................................. 83

4.2.7. A impessoalidade como moralidade, publicidade, finalidade e imparcialidade........ 84

4.2.8. A impessoalidade como isonomia, finalidade e imputação ....................................... 86

4.2.9. A impessoalidade como igualdade, finalidade e imparcialidade .............................. 89

4.2.10. A impessoalidade como isonomia, imputação e objetividade ................................ 91

4.2.11. A impessoalidade como neutralidade, finalidade e legalidade ...............................91

4.2.12. A impessoalidade como imparcialidade, finalidade e imputação...........................92 


\section{$\mathrm{V}$ - CONSIDERAÇÕES SOBRE DOIS TERMOS: IMPESSOAL E}

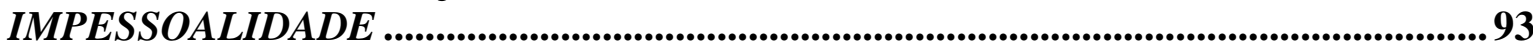

5. 1. Uma Razão Jurídica crítica como um predicado do princípio de impessoalidade ......97

\section{VI - ALGUNS INTÉRPRETES DO BRASIL E A EXPERIÊNCIA ADMINISTRATIVA: A RELAÇÃO ENTRE ESTADO, DIREITO E SOCIEDADE}

6.1 - Considerações iniciais: a ideia de Patrimonialismo 101

6.2. O início do Direito Administrativo no Brasil: algumas ideias.................................... 102

6.3. O registro de alguns intérpretes do período pós-imperial até a Constituição de 1988: a fase preponderantemente de ampliação do Estado

VII - UM CONCEITO DO PRINCÍPIO DE IMPESSOALIDADE

7.1. Considerações iniciais: a noção de Formalismo .... 126

7.2. O princípio de impessoalidade, nos termos do art. 37, da Constituição de 1988 ........ 128

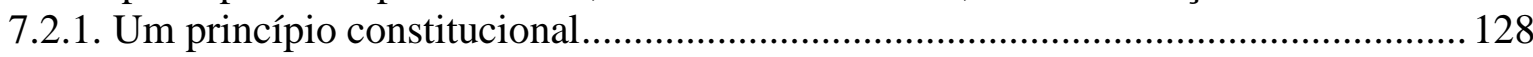

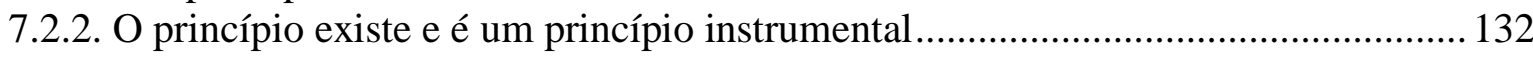

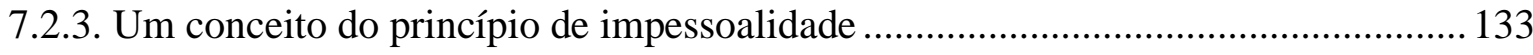

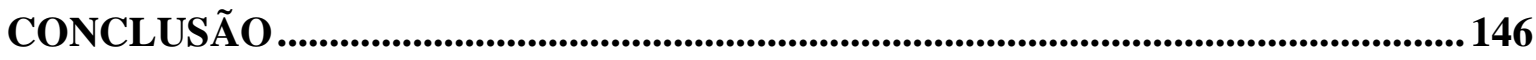

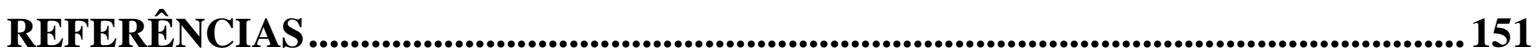


O conceito jurídico do princípio de impessoalidade no Direito Administrativo brasileiro: uma releitura ${ }^{1}$.

\section{APRESENTAÇÃO}

Maria Sylvia Zanella Di Pietro² afirma que "não existe um novo direito administrativo, no sentido de que seus institutos básicos estão sendo substituídos por outros antes inexistentes. Os temas fundamentais do direito administrativo continuam sendo objeto de estudo e tratados em praticamente todos os manuais pertinentes a esse ramo do direito, inclusive no direito europeu continental. O que existe, na feliz expressão de Odete Medauar, é um direito administrativo em evolução (...) O direito administrativo humaniza-se".

Esta poderosa humanidade vem surgindo, em evolução, e, nos dias de hoje, rompe - e não apenas substitui uma categoria do Direito Administrativo -, um clássico princípio $^{3}$ do Direito Administrativo de que o rei não pode errar, contido nas expressões the king can do no wrong ou Le roi peut mal faire.

É, pois, o que se nota da manchete do jornal El país ${ }^{4}$, de Madri, em que se registrou que o Rei pede perdão: “A história conta que os reis não pedem perdão. Quando muito, retificam sem reconhecê-lo expressamente. Mas a história, não apenas espanhola, mas as das monarquias ocidentais, deu ontem um avanço inesperado em Madri. Com olhar compungido, um tom de voz baixíssimo, e uma clara intenção de recuperar o

\footnotetext{
${ }^{1}$ Ao escrever sobre o tema da atividade contratual da Administração Pública, Maria João Estorninho (ESTORNINHO, Maria João. Requiem pelo Contrato Administrativo. Coimbra: Almedina, 2003. pp. 13-14), faz menção a dois sentimentos que inspiram aqueles que estudam este assunto: "um esforço de aprofundamento" ou "um mero exercício de "arejamento periódico"”. Entretanto, a autora registra que a escolha dela pelo tema de seu mestrado não era ditado por nenhum destes sentimentos. Comparando, então, o tema dos contratos da Administração com um “"velho sótão', terreno propício a descobertas inesperadas e onde, sob a aparente quietude, tudo continua em desordem", ela dizia, "neste trabalho" esperar "poder descobrir uma ou outra dessas 'relíquias' e, em alguma medida, contribuir para repor a ordem" e que se conseguisse "afastar algumas das "teias de aranha", já se dava por satisfeita. Parafraseando a professora portuguesa, pode-se comparar o tema "princípio de impessoalidade" como um "velho porão". E tal como o daquela professora, este trabalho de dissertação de mestrado também não é inspirado pelos dois referidos sentimentos. Abordando o tema sobre uma perspectiva distinta, esperamos poder contribuir para uma releitura do princípio de impessoalidade; e se conseguirmos afastar a porta deste sótão o suficiente para que um pouco de luz ou ar passe por ela, a ponto de ao menos chamar a atenção à importância do tema e cumprir as exigências acadêmicas, já nos daremos por satisfeito. (grifos do autor)

${ }^{2}$ DI PIETRO, Maria Sylvia Zanella; RIBEIRO, Carlos Vinícius Alves (coords). Supremacia do interesse público e outros temas relevantes do direto administrativo. São Paulo: Atlas, 2010. p. 9.

${ }^{3}$ Maria Sylvia Zanella Di Pietro, sobre Teoria da irresponsabilidade, na época dos Estados Absolutos, referese à expressão ideia como um princípio (DI PIETRO, Maria Sylvia Zanella. Direito Administrativo. $25^{\mathrm{a}}$ ed. São Paulo: Atlas, 2012. p. 699).

4 Disponível em <http://politica.el.pais.com/politica/2012/04/18/actualidad/1334782548_184215.html>. Acesso em 20.05.2012. (tradução nossa).
} 
favor perdido da opinião pública, o Rei da Espanha rompeu em onze palavras uma das tradições mais arraigadas em qualquer monarquia: Sinto muito, equivoquei-me e não voltará a ocorrer".

A evolução não cessa! O Brasil e seu Direito Administrativo evoluem e são construídos a cada dia ${ }^{5}$. E evidentemente não são construídos por uma única pessoa. Aliás, em relação ao Brasil, poder-se-ia dizer que ele tem sido (re)construído várias vezes e por e para milhões de pessoas.

Na introdução de A construção do Brasil, de Jorge Couto ${ }^{6}$, há a seguinte afirmação: "A adoção dos sistemas de arrendamento e, posteriormente, de <<capitanias de mar e terra > - formas de integração do Brasil no Império Português no decurso das três primeiras décadas de Quinhentos - é interpretada no contexto das opções estratégicas globais definidas pela Corte de Lisboa". (p.16)

Este dissertação de Mestrado trata de um tema que poderia ser incluído entre mais uma destas múltiplas opções estratégicas globais adotadas pelo Poder. Com uma pequena diferença: agora não mais definida pela Corte de Lisboa para o Brasil, mas pelo próprio Brasil para si mesmo.

Diz ainda o autor daquela introdução que tendo "o Brasil resultado de um processo de construção empreendido pelos Portugueses em cooperação ou conflito com outros grupos étnicos, ou seja, Ameríndios e Africanos, destacam-se os aspectos relacionados com os intercâmbios civilizacionais euro-afro-americanos - da Lingüística à Zoologia e da Gastronomia às doenças - que deram origem a uma criação profundamente original e distinta de cada uma das suas componentes".

É mesmo assim, o Brasil: único. Único, mas não surgiu ex nihilo.

O princípio de impessoalidade, expresso no art. 37, caput, da Constituição da República, fruto da contínua experiência de (re)construção políticoadministrativa do país, é o tema deste trabalho de dissertação de Mestrado aqui na Universidade de São Paulo - USP.

Mais especificamente, pretende-se fazer uma releitura deste princípio, levando-se em conta a nova ordem constitucional oficialmente estabelecida em 1988. Dizse releitura porquanto a doutrina brasileira o tem interpretado sobre inúmeros enfoques, trazendo ambiguidade a seu sentido.

\footnotetext{
${ }^{5}$ Aliás, frise-se que temos como objetivo fundamental "construir uma sociedade livre, justa e solidária" (CR, art. $3^{\circ}$, inc. I)

${ }^{6}$ COUTO, Jorge. A Construção do Brasil. Lisboa: Edições Cosmos, 1995. p. 16.
} 
O trabalho é dividido em introdução, seis capítulos e conclusão.

$\mathrm{Na}$ introdução tentamos trazer a ideia do princípio de impessoalidade como uma concepção (nova) de mundo. Uma nova forma de compreender e agir no mundo, de nos relacionarmos no mundo administrativo. E isso felizmente se faz com o auxílio de ideias de outros autores que, em suas áreas de autuação (distintas do Direito, por vezes), contribuíram para que pudéssemos estabelecer pontos de apoio ao caminho seguido para apreender nossa realidade. Foi, na verdade, a reafirmação de que não estamos sozinhos e não fazemos nada sozinhos. Algo que, em se tratando de uma tese acadêmica, Humberto $\mathrm{Eco}^{7}$ chamaria de humildade científica.

Prossegue-se com considerações sobre a Constituição da República de 1988, tentando estabelecer algumas de suas premissas: sua preocupação com o ser humano, os fins do Estado, o processo de constitucionalização, a Democracia e o papel da Administração Pública como um dos integrantes da nova relação político-administrativa surgida desta nova ordem - o princípio parece ser uma novidade.

O segundo capítulo cuida de considerações sobre o Direito Administrativo: alguns dados históricos, sua relação com a Constituição, características, importância e função. Informações relevantes e que parecem contribuir para a compreensão do princípio estudado.

Adiante, fez-se uma pesquisa bibliográfica na doutrina nacional para investigar a compreensão que alguns autores têm sobre este princípio constitucional. Pululam interpretações. Mas, em síntese, poder-se-ia reduzi-las a basicamente três concepções: aqueles que o identificam com o princípio de finalidade (ou interesse público), com o princípio de igualdade (ou isonomia) ou com o princípio de imparcialidade. Nesta última, ao que parece, o ponto de partida é o direito estrangeiro: o princípio de imparcialidade concebida por países que adotam o contencioso administrativo, diversamente do que ocorre entre nós.

No quarto capítulo a preocupação era compreender os termos impessoal e impessoalidade. E aqui um dos pontos de apoio foi a lição de Hannah Arendt sobre o termo persona e a do administrativista Alejandro Nieto sobre razão jurídica crítica. Parece-nos que o léxico tem contribuído para a interpretação que os autores pesquisados têm feito deste princípio constitucional do Direito Administrativo.

\footnotetext{
${ }^{7}$ ECO, Humberto. Como se faz uma tese. Gilson Cesar Cardoso de Souza (Trad.). São Paulo: Perspectiva, 2006. p. 10-12 e 112-113.
} 
Em seguida, passamos a examinar - sem a pretensão de exaurir o tema alguns dados que nos pareceram pertinentes sobre o sistema jurídico-administrativo do período imperial e o registro doutrinário feito por alguns autores de Direito Administrativo da época e de administrativistas e sociólogos que surgiram no curso do período que se seguiu até chegarmos em 1988. Cremos que a sociedade se desenvolve como que por uma luta de poderes e interpretações do mundo, interpretações e construções de categorias jurídicas para o exercício do poder. Uma simbiose, v.g., entre construções de direito substantivo e de direito adjetivo que sustentavam o interessante período imperial. Hoje temos o reconhecimento de direitos fundamentais, uma tendência ao amplo acesso à Justiça com as garantias respectivas e a inafastabilidade de jurisdição (CR, art. $5^{\circ}$, inc. $\mathrm{XXXV);} \mathrm{ontem,} \mathrm{v.g.,} \mathrm{a} \mathrm{distinção} \mathrm{entre} \mathrm{interesses} \mathrm{e} \mathrm{direitos} \mathrm{e} \mathrm{uma} \mathrm{processualidade} \mathrm{graciosa}$ e contenciosa. Um mundo cujo ponto de referência era o Estado (rectius: os ocupantes, os donos do poder) e em que a Sociedade não era senão um coadjuvante nesta trama políticojurídico-administrativa.

O novel princípio parece contribuir para a inversão desta referência.

No sexto capítulo chegamos ao princípio de impessoalidade. Aqui, trazendo a noção de formalismo de Fred W. Riggs, por intermédio do sociólogo Alberto Guerreiro Ramos, sustentamos a existência deste princípio, sua natureza instrumental e sua identidade dúplice: um princípio jurídico que impulsiona a processualidade e o controle finalísticos para o adequado agir administrativo na República Federativa do Brasil.

A realidade é construída socialmente. Sua apreensão é fundamental para que possamos continuar construindo coletivamente e nos guiando neste ambiente coletivo: é preciso conversar ${ }^{8}$ para construir!

Sobre construir, ocorreram-me três episódios nacionais. O primeiro vem da época do império, do pensamento de Joaquim Manuel de Macedo. O outro é mais recente, vem de Paulo Mendes Campos. O outro, por fim, vem de Carlos Drummond de Andrade. Ideias que nos parecem afins do ambiente e do espírito do princípio em questão.

\footnotetext{
${ }^{8}$ Floriano de Azevedo Marques Neto, por exemplo, fala sobre o fato de que o ato administrativo tem "um brutal déficit de comunicação com o meio cultural, social, econômico" e uma "absoluta indiferença para com os administrados e com a sociedade que, em última instância, são destinatários e razão de ser da prática destes atos". (MARQUES NETO, Floriano de Azevedo. A superação do ato administrativo autista. In MEDAUAR, Odete; SCHIRATO, Vitor Rhein (orgs). Os caminhos do ato administrativo São Paulo: Revista dos Tribunais, 2012).
} 
Em seu livro Memórias do sobrinho do meu tio ${ }^{9}$, Joaquim Manuel de Macedo conta que o protagonista da história em A carteira de meu tio ${ }^{10}$, que se refere à Constituição do Império como a defunta, herda parte do patrimônio do tio, com três condições: a primeira era "nunca se afastará da Constituição do Império". Segue o episódio de entrega da Constituição: vão ao jardim e nele existe um túmulo em que ela está enterrada, cujo epitáfio é o seguinte: “Aqui já quem nunca nasceu”.

Para auxiliar o sobrinho na interpretação do país, o tio dá-lhe a Constituição do Império. E há duas passagens interessantes. Em uma, o sobrinho exclama: "a Constituição contém palavras mortas". Noutra, o tio observa, ao entregar-lhe a Constituição e uma carteira: "vai e viaja com ela; observa o que se passa em nossa terra, e compara o que observares com o que ela te disser em seus sábios preceitos: escreve tudo; porque quando a Carteira de teu tio estiver cheia das tuas impressões de viagem, e enfim voltares a ter comigo, terás já aprendido a grande verdade, a única tábua de salvação do Estado, remédio santo e exclusivo para curar todos os nossos sofrimentos políticos; isto é, terás reconhecido por experiência que a Constituição nunca foi e não é ainda hoje executada; e que, quando o for, o Brasil será feliz e apreciará devidamente e mais que até agora a sua bela monarquia".

Em O mais estranho dos países ${ }^{11}$, numa crônica intitula Dar um jeitinho, Paulo Mendes Campos registra que há duas constantes na maneira de ser do brasileiro: a capacidade de adiar e a capacidade de dar um jeito. Duas ideias interdependentes: "há uma forma de vencer a interminável procrastinação: é dar um jeito”. Conta-nos o escritor mineiro uma crônica em que observa que a teoria de dar um jeito "se difundida a tempo na Europa, teria evitado umas duas guerras carniceiras".

No poema Mundo Grande ${ }^{12}$, aqui sintetizado, Carlos Drummond de Andrade expressa a liberdade, não a da ilusão do posso tudo, tampouco no conformismo de nada posso, mas uma disposição para interpretar e decifrar as direções e os sentidos:

"Não, meu coração não é maior que o mundo (...) Só agora vejo que nele não cabem os homens. Os homens estão cá fora, estão na rua. A rua é enorme (...) Só agora descubro como é triste ignorar as coisas. (Na solidão de indivíduo desaprendi a linguagem

\footnotetext{
9 MACEDO, Joaquim Manuel de. Memórias do sobrinho do meu tio. Organização e notas de Flora Süssekind.São Paulo: Penguin Classics Companhia das Letras, 2001.

${ }^{10}$ Idem. A carteira de meu tio. Introdução, posfácio e notas de Fábio Bortolazzo Pinto. Porto Alegre: L\&PM, 2010.

${ }^{11}$ CAMPOS, Paulo Mendes. O mais estranho dos países: crônicas e perfis. Seleção e apresentação de Flávio Pinheiro; posfácio de Sérgio Augusto. São Paulo: Companhia das Letras, 2013.

${ }^{12}$ ANDRADE, Carlos Drummond de. Poesia Completa e prosa. $4^{\text {a }}$ ed. Petrópolis: Nova Aguilar, 1977.
} 
com que os homens se comunicam) (...) Nunca ouvi voz de gente (...) Ilhas perdem o homem. Entretanto alguns se salvam e trouxeram a notícia de que o mundo, o grande mundo está crescendo todos os dias, entre o fogo e o amor. Então, meu coração também pode crescer. Entre o amor e o fogo, entre a vida e o fogo, meu coração cresce dez metros e explode. - Ó vida futura! Nós te criaremos".

O princípio de impessoalidade é uma exclamação impositiva de que a função administrativa é obra conscientemente coletiva e tem o ser humano como o fim: o Direito é comunicação, a impessoalidade, a forma com que as pessoas de Estado e as da Sociedade se dialogam e decidem. Um diálogo que tanto pode ser iniciado por estes quanto por aqueles: não há distinção entre atos praticados por provocação do interessado e aqueles praticados de ofício pela Administração Pública (em que se insere, aliás, a maior parte dos atos discricionários). Já se escreveu o seguinte:

"A discricionariedade está - doutrina Fleiner - em permitir o legislador que a autoridade administrativa escolha, 'entre as várias possibilidades de solução, aquela que melhor corresponda, no caso concreto, ao desejo da lei ${ }^{31}$. Mas deverá sempre estrita observância à lei, porque a exorbitância do poder discricionário constitui ato ilícito, como toda ação voluntária carente de direito.

A esse propósito escreveu Goodnow que o poder discricionário não autoriza nem legitima 'medidas arbitrária, caprichosas, inquisitórias ou opressivas ${ }^{, 32}$, o que corresponde à afirmativa de Nunes Leal: 'Se a Administração, no uso de seu poder discricionário, não atende ao fim legal, a que está obrigada, entende-se que abusou do poder'. 33

Qual será, entretanto, o fim legal a que o jurista pátrio se refere? Bielsa e Bonnard nos respondem, quase com as mesmas palavras: o fim legal é o que vem expresso ou subentendido na lei. ${ }^{34} \mathrm{E}$, na realidade, assim é. A lei administrativa é sempre finalística: almeja um objetivo a ser atingido pela Administração, através de ato ou atos jurídicos que constituem meios para a consecução de tais fins. A atividade do administrador público vinculada ou discricionária - há de estar sempre dirigida para o fim legal, que em última análise, colima o bem comum.

Discricionários, portanto, só podem ser os meios e modos de administrar; nunca os fins a atingir. Em tema de fins - a lição é de Bonnard - não existe jamais, para a Administração, um poder discricionário. Porque não lhe é nunca deixado poder de livre 
apreciação quanto ao fim a alcançar. O fim é sempre imposto pelas leis e regulamentos, seja explícita, seja implicitamente"13.

Será isso mesmo?

Enfim, ontem, L'État c'est moi; hoje, L'État sont nous pour de vrai.

${ }^{13}$ MEIRELLES, Hely Lopes. Direito Administrativo Brasileiro. $21^{\mathrm{a}}$ ed. atualizada por Eurico de Andrade Azevedo, Délcio Balestero Aleixo e José Emmanuel Burle Filho. São Paulo: Malheiros, 1996. pp. 152-153. Observe-se que as notas de rodapé fazem menção a obra dos autores citados. 


\section{I - INTRODUÇÃO}

Toda construção jurídica, observa Jean Rivero ${ }^{14}$, pressupõe uma concepção de mundo, "resposta dada à indagação de Pascal: ‘Afinal, que é o homem'?”. Esta resposta, explícita, implícita ou mesmo inconscientemente, como ensina o professor francês, "não pode deixar de ser dada, necessariamente. Eis o motivo pelo qual todo trabalho jurídico sério pressupõe cultura geral que dá acesso às principais respostas dadas pelo homem aos problemas de seu destino".

Em se tratando de Direito Administrativo brasileiro ${ }^{15}$, uma destas respostas é a concepção do princípio de impessoalidade, expressamente inscrito no art. 37, caput, da Constituição da República ${ }^{16}$.

${ }^{14}$ RIVERO, Jean. Curso de Direito Administrativo Comparado. $2^{\mathrm{a}}$ ed. J. Crettela Jr (Trad.). São Paulo: RT, 2004. pp. 98-99. A compreensão daquilo que a doutrina apresenta para o princípio de impessoalidade não responde às necessidades e desafios da nova ordem constitucional em matéria de atuação da Administração Pública, dando a impressão de que tal compreensão reflete um padrão de comportamento arraigado numa concepção de mundo de que o Estado é o todo-poderoso, onipotente, onisciente e onipresente, e prescinde da sociedade para agir administrativamente. Isso, por certo, gera consequências nefastas para a coletividade, ora impedindo a concreção de objetivos constitucionais, ora fragilizando a atividade administrativa e, por conseguinte, mantendo um status quo indesejável e perpetuando débeis mecanismos de controle.

${ }^{15}$ Este trabalho pressupõe o Direito Administrativo como um ramo do direito que tem por objeto a função administrativa. Embora não seja objeto deste trabalho, sobre ela, a seguinte lição: "Quanto à função administrativa, existem basicamente duas ópticas através das quais se pode proceder à sua definição. Tradicionalmente, era adoptado um critério negativo: a função administrativa abrangia as actividades públicas que não se pudessem reconduzir às restantes funções do Estado. Mas a função administrativa pode ser definida de modo positivo: ela compreende a actividade pública contínua tendente à satisfação das necessidades colectivas em cada momento seleccionado, mediante prévia opção constitucional e legislativa, como desígnios da colectividade política - ou seja, os interesses públicos contingentes. A actividade em que se consubstancia a função administrativa é multiforme, abrangendo designadamente a produção de bens e a prestação de serviços, bem como as actuações que visem a obtenção e gestão dos recursos materiais e humanos a alocar ao seu desenvolvimento; o seu âmbito concreto varia em função dos interesses públicos que, em momento histórico, sejam constitucional e legislativamente considerados relevantes, o que por sua vez depende de diversos factores sócio-culturais e políticos: por exemplo, se, no estado social atual, se entende caber na função administrativa a efectivação de prestações de tipo assistencial ou de solidariedade social aos cidadãos, já no Estado liberal, pelo contrário, se entendia que cabia essencialmente à função administrativa apenas a preservação da ordem e da segurança públicas" (conforme o original). (RIVERO, Jean. Direito Administrativo Geral - Introdução e princípios fundamentais. $3^{\mathrm{a}}$ ed. Portugal: D. Quixote, 2010 p. 41. T. 1).

16 "A administração pública direta e indireta de qualquer dos poderes da União, dos Estados, do Distrito Federal e dos Municípios obedecerá aos princípios de legalidade, impessoalidade, moralidade, publicidade e eficiência e, também, ao seguinte: (...)". A Constituição do Estado de São Paulo também faz menção a este princípio em seu art. 111, nos seguintes termos: "A administração pública direta, indireta ou fundacional, de qualquer dos Poderes do Estado, obedecerá aos princípios de legalidade, impessoalidade, moralidade, publicidade, razoabilidade, finalidade, motivação, interesse público e eficiência". A Lei n. 8.666/93 também faz menção à impessoalidade: "A licitação destina-se a garantir a observância do princípio constitucional da isonomia e a selecionar a proposta mais vantajosa para a Administração e será processada e julgada em estrita conformidade com os princípios básicos da legalidade, da impessoalidade, da moralidade, da igualdade, da publicidade, da probidade administrativa, da vinculação ao instrumento convocatório, do julgamento objetivo e dos que lhes são correlatos". 
Passados $25 \operatorname{anos}^{17}$ desde a outorga desta Constituição, em 5.10.1988, a doutrina brasileira não revela consenso sobre o que significa este princípio constitucional da Administração Pública. Ou seja, é ainda um incógnito entre nós. Ora ele é compreendido como sendo o princípio de igualdade; ora como o princípio de finalidade; ora como a combinação destes com outros adjetivos; outras vezes, e agora com influência do direito europeu, como o princípio de imparcialidade. Aliás, há quem sustente que ele nem mesmo é um princípio ${ }^{18}$.

A despeito de se conceber divergências conceituais no âmbito do Direito - e no Direito Administrativo há muitas ${ }^{19}$-, admitir esta realidade em relação ao princípio de impessoalidade é o mesmo que lhe conferir o estatuto de um nada ${ }^{20}$ : ele nada significa, não pode ser considerado como uma realidade para nossa consciência; sua multiformidade gera-lhe multivocidade e, assim, seu conceito se mantém indefinido e incerto.

Quando muito, poder-se-ia utilizá-lo como expressão sinônima daqueles princípios mais consagrados. A propósito, não seria de todo estranho agregar às inúmeras

17 Lívia Maria Armentano Koenigstein Zago inicia sua monografia fazendo menção ao tempo decorrido desde a outorga da Constituição e a realidade deste princípio: "Mas o princípio da impessoalidade constituise em novidade no Direito pátrio, foi dado à luz com a Constituição de 1988. E, decorridos mais de dez anos de vigência da Constituição, o princípio da impessoalidade continua a ser uma incógnita, estampado na Carta, mas sem que lhe tenha sido dada a devida atenção e a necessária análise”. (ZAGO, Lívia Maria Armentano Koenigstein. O princípio da impessoalidade. Rio de Janeiro: Renovar, 2001. p. 2).

${ }^{18}$ STRECK, Lênio Luiz. Verdade e Consenso: constituição, hermenêutica e teorias discursivas. , $4^{\mathrm{a}}$ ed. São Paulo: Saraiva, 2011. pp. 582-583. Acrescente-se que José Afonso da Silva refere-se ao princípio como "O princípio ou regra da impessoalidade da Administração Pública" (SILVA, José Afonso da. Curso de Direito Constitucional Positivo. 22a ed. revista e atualizada nos termos da Reforma Constitucional - até a Emenda Constitucional n. 39, de 19.12.2002.São Paulo: Saraiva, 2011.p. 647).

19 A título de exemplo, o professor J. Cretella Júnior (CRETELLA JÚNIOR, J. Curso de Direito Administrativo de acordo com a Constituição de $1998.11^{\mathrm{a}}$ ed. revista e atualizada, Rio de Janeiro: Forense, 1991) traz inúmeras situações de divergências conceituais no direito administrativo: falta de uniformidade sobre o conceito de autarquia administrativa (p. 41), desencontros sobre um conceito de fonte de direito administrativo (p. 169), controvérsia sobre o conceito de Administração Pública (p. 138), desencontros sobre a definição de ato administrativo (p. 190), problemas de definição sobre atos políticos (p. 232), imprecisão na individuação terminológica do tema desvio de poder (p. 291).

${ }^{20}$ Apontando as distintas interpretações que a doutrina faz do princípio de impessoalidade, Fábio Lins de Lessa Carvalho (CARVALHO, Fábio Lins de Lessa. O princípio da impessoalidade nas licitações. Maceió: EDUFAL, 2005. p. 57) anota que "boa parte da doutrina brasileira preferiu equiparar o princípio da impessoalidade a outros princípios já consagrados nos manuais de Direito Administrativo. Esta atitude, além de repreensível sob o ponto de vista científico, desconsidera todo o avanço conquistado com a inserção da impessoalidade na Constituição de 1988". Também apresentando impressões e ponderações sobre o tema, Fábio Medina Osório (OSÓRIO, Fábio Medina. Teoria da improbidade administrativa: má gestão pública; corrupção; ineficiência - prefácio de Eduardo Garcia de Enterría. $3^{a}$ ed. São Paulo: Editora Revista dos Tribunais, 2013. p. 134) observa que "é necessário, inclusive, redimensionar a impessoalidade (...) Isto equivale a dizer que a impessoalidade pode ensejar a construção e a consolidação de uma máquina administrativa eficiente e estável, contínua e objetiva, ao mesmo tempo em que pode e deve ditar novos critérios para distribuição de cargos públicos de confiança dos administradores. Lamentavelmente, tais funções não têm sido desempenhadas por esse princípio constitucional, certamente porque seus conteúdos resultam absolutamente empobrecidos de abordagens e falas recheadas de obviedades distantes da realidade organizacional da vida administrativa. A impessoalidade, como princípio jurídico, tem apresentado um conteúdo que, de um lado, discrepa da realidade funcional da Administração Pública e, de outro, fica aquém de suas potencialidades transformadoras mais radicais". 
compreensões citadas que se cogitasse de que este princípio não fosse, na verdade, o próprio princípio de legalidade ${ }^{21}$. E novamente sua sinonímia evitaria o incômodo de se repetir os nomes daqueles ao que ele tem sinonímia. Enfim, seu signo integraria o conjunto de possibilidades léxicas, muito comum na literatura ou na poesia, que não exige tanta precisão terminológica como a que se impõe à ciência jurídica.

Afinal de contas, existe o princípio de impessoalidade? Qual o porquê deste princípio? Para quê este princípio? Como se dá este princípio? Que é, enfim, o princípio de impessoalidade?

Quando o homem formula problemas sobre a realidade de sua vida, ele não mais pretende a significação da realidade, porquanto para formular a realidade como problema, ele já precisa que esta tenha significação. Assim, depois de resolvido “o problema no campo da inteligência, o homem tem a interpretação, que então precisa ser confrontada com a realidade para que adquira graus de certeza e de confiança. O homem precisa confiar em suas interpretações para poder utilizá-las como guias seguros de sua ação sobre a realidade. A confiança em uma interpretação se chama crença. Uma interpretação para se tornar objeto de crença deve gozar de algum grau de certeza. Neste caso dizemos que a realidade recebeu uma apropriação pelo homem. Ou seja, o homem se apropria da realidade quando elabora interpretações em que tem razões para acreditar que sejam guias seguros e eficazes de sua ação no mundo" 22 .

Esta "apropriação da realidade" 23 se manifesta em três planos: no plano da consciência, no plano da linguagem e no plano da vida social do homem. Naquele, a apropriação se dá com a crença; neste outro, com a interpretação; e, neste último, como ação programada e consciente sobre as coisas e a natureza.

A interpretação da realidade, anota José Auri Cunha ${ }^{24}$, permite que possamos compreender o significado das coisas que acontecem, por que acontecem, para que acontecem e como poderemos agir para tirar proveito da ordem desses acontecimentos. Assim, enquanto uma significação da realidade alimenta a nossa compreensão sobre esta

\footnotetext{
${ }^{21}$ Discorrendo sobre a atividade pública, Roberto Dromi (DROMI, Roberto. Derecho Administrativo. $12^{\mathrm{a}}$ ed. atualizada. Buenos Aires, Madrid/México: Ciudad Argentina: Hispania Libros, 2009. p. 169) afirma que ela está regulada juridicamente e que sua tarefa é regida por certos princípios jurídicos de ponderação política, como o princípio de legalidade, "que assegura ao indivíduo o respeito à normatividade e prelação jurídica, a igualdade, a razoabilidade, o controle e a responsabilidade jurídicos, como consequência da adoção do Estado de direito como modelo para a organização pública". Vale dizer, toda a principiologia estaria inserida no princípio de legalidade.

${ }^{22}$ CUNHA, José Auri. Filosofia - iniciação à investigação filosófica - prefácio de Celso Favaretto. São Paulo: Atual Editora, 1992. pp. 66-67.

${ }^{23}$ Idem, ibidem. p. 68.

${ }^{24}$ Idem, ibidem. p. 60.
} 
realidade, uma interpretação dela suscita e instrumentaliza a nossa necessidade de ação sobre ela.

A Constituição da República de 1988, no que diz respeito ao Direito Administrativo, é esta nossa realidade ${ }^{25}$ : é o que faz sentido para nós, é o que é valor ${ }^{26}$ para nós, é o que se pretende seja realizado. Todos os dispositivos dela de alguma forma exigem interpretação que precisa ser confrontada com esta realidade e passe a possibilitar a ação sobre esta realidade.

O trabalho jurídico, na lição de Agustín Gordillo ${ }^{27}$, não é possível sem uma imaginação criativa. De uma criatividade que recebe contribuição de experiências de outros autores ou de uma série de outros ramos do conhecimento. Vale dizer, é, de fato, um impulso criativo que surge do conhecimento dos fatos, mas é essencialmente um salto de imaginação.

É inspirado por esta lição - cremos, própria da academia - que se propõe, superando a semântica, dar respostas aos problemas acima formulados e descobrir, atento a sua sintaxe constitucional, a partir da noção da pragmática ${ }^{28}$, o significado jurídico do princípio de impessoalidade inscrito no art. 37, caput, da Constituição da República.

${ }^{25}$ Discorrendo sobre movimento e desconstrução do Direito Administrativo, Luís Filipe Colaço Antunes lembra Léon Duguit (1913) e Otto Mayer (1923): “Em resumo, enquanto para um dos construtores de catedrais do direito administrativo francês o direito público-administrativo passava por profundas transformações, um dos fundadores do direito administrativo alemão, uma década depois, afirmava peremptoriamente que o Direito Constitucional passa enquanto o Direito Administrativo permanece". Para este nosso trabalho, quando uma Constituição surge, o Direito Administrativo deve se conformar a ela. Ou, na expressão de Fritz Werner (1959), também lembrado pelo administrativista português: "o direito administrativo é direito constitucional concretizado" (WERNER, Fritz. O Direito Administrativo sem Estado: crise ou fim de um paradigma? Coimbra: Coimbra Editora, 2008. p. 34).

${ }^{26}$ Sobre uma distinção interessante sobre valor, a lição de André Comte-Sponville no verbete respectivo: "é preciso distinguir o que tem valor (...) e o que é um valor, que não tem preço e não poderia ser trocado validamente por dinheiro, nem por outro valor (...) os valores não tem preço: têm uma dignidade, como dizia Kant, que não admite o equivalente e não pode ser trocado por outra coisa. Devemos considerá-lo um absoluto, então? De maneira nenhuma, parece-me, pois resta compreender de onde vem esse valor que lhe prestamos ou que ele é. Um valor é o que vale, dizia eu; mas o que é valer? É ser desejável ou desejado (...) Como a justiça seria um valor, se ninguém desejasse a justiça? Como a verdade poderia valer, se ninguém a apreciasse ou a desejasse? É o que Espinosa, num escólio abissal da Ética, nos convida a pensar: 'Não nos esforçamos por nada, não queremos, não apetecemos nem desejamos coisa alguma porque a julgamos boa; ao contrário, julgamos que uma coisa é boa porque nos esforçamos por ela, a queremos, apetecemos e desejamos' (III, 9, escólio)". (DICIONÁRIO FILOSÓFICO. Eduardo Brandão (Trad.). São Paulo: Martins Fontes, 2003).

${ }^{27}$ GORDILLO, Agustín. El Metodo em Derecho - Aprender, enseñar, escribir, crear, hacer. Madri: Civitas Ediciones, 1988. p. 100. (tradução nossa).

${ }^{28}$ Segundo o Dicionário de Filosofia (ABBAGNANO, Nicola. Dicionário de Filosofia. Alfredo Bosi (Trad. e rev. da $1^{\mathrm{a}}$ ed. Brás. Ivone Castilho Benedetti (revisão da tradução e tradução dos novos textos). $6^{\mathrm{a}}$ ed. São Paulo: WFM Martins Fontes, 2012), o termo PRAGMÁTICA, "No âmbito das ciências contemporâneas da linguagem (...) indica as pesquisas que estudam a língua do ponto de vista do uso que os falantes fazem dela para comunicar-se, portanto, entre coisas, do ponto de vista dos contextos, das atividades, das interações sociais em que a língua é usada, das intenções e das crenças dos falantes. Os estudos pragmáticos, nascidos em área filosófica, hoje dizem respeito, sobretudo, à linguística, mas utilizam conceitos e métodos 
Baseando-se na definição tradicional encontrada em Morris e Carnap, o professor Danilo Marcondes ${ }^{29}$ ensina que "a sintaxe examina as relações entre os signos; a semântica estuda a relação dos signos com os objetos a que se referem; e a pragmática diz respeito à relação dos signos com seus usuários e como estes os interpretam e os empregam". Para ele, pode-se considerar que há duas linhas de desenvolvimento para a compreensão da pragmática na filosofia da linguagem: a que a considera uma extensão da semântica, em que, para ter significado, as expressões dependem do contexto, "sem o que não podem ter a sua referência determinada", e a que consiste em considerar o significado como determinado pelo uso, "mesmo que originariamente os autores que formularam essas concepções não tenham utilizado este termo em relação às suas propostas. Essas concepções acrescentam à consideração do contexto a ideia de que a linguagem é uma forma de ação e não de descrição do real". Em relação àquelas linhas de desenvolvimento da Pragmática, com base na lição do filósofo austríaco Ludwig Wittgenstein (1889-1951), em Investigações filosóficas, o professor Danilo Marcondes acrescenta que a primeira alternativa é representada pela concepção de significado de uma palavra como seu uso em um determinado contexto, "o significado não deve ser entendido como algo fixo e determinado, como uma propriedade imanente à palavra, mas sim como a função que as

provenientes também da sociologia (...), da psicologia (...), da antropologia (...). O termo foi cunhado como nome para uma disciplina de Ch. W. Morris, que chamou de 'P' a parte da semiótica (...) que trata das relações entre os signos e seus intérpretes, ou seja, estuda os signos nas situações concretas em que os intérpretes os usam para comunicar-se (...) Era muito amplo o conceito de P. que Morris definiu pela primeira vez em 1938 (...) A definição de Morris foi retomada por R. Carnap (...) A ideia carnapiana de P. estava, próxima da de Morris. Ao contrário deste porém, Carnap considerava a P. uma disciplina essencialmente linguística, enquanto Morris a pensava como uma disciplina mais amplamente semiótica, orientada para a consideração, também, do uso dos signos não-verbais (...)". Os conceitos de linguagem e significação estudados por ambos foram desenvolvidos por filósofos, dentre eles L. Wittgenstein, cujas reflexões "determinaram em filosofia uma mudança radical no modo de olhar os fenômenos da linguagem e da significação. Para Wittgenstein, a língua não é feita de enunciados que representam ou descrevem o mundo como queria a concepção tradicional que Wittgenstein fazia remontar a Agostinho e à qual ele mesmo aderira no Tratactus (1922) -, nem o significado das palavras que compõem os enunciados é dado pelo objeto que eles denota (...) 'o significado de uma palavra é o seu uso na linguagem'. Isso significava focalizar a reflexão filosófica e linguística naquilo que os falantes fazem com a língua, na atividade com que os indivíduos, inseridos em contextos sociais regulados e interagindo entre si de modo coordenado, produzem e interpretam significados". (grifos do autor)

${ }^{29}$ MARCONDES, Danilo. A pragmática na filosofia contemporânea. Rio de Janeiro: Jorge Zahar Ed., 2005. pp. 8-12. ((Filosofia passo a passo, v. 59). Cláudio Costa (COSTA, Cláudio. Filosofia da linguagem . Rio de Janeiro: Zahar, 2002. pp. 38-39. (Filosofia passo a passo, v. 5). observa que "o significado de uma expressão (palavras, frase) é o seu uso ou aplicação na linguagem. As palavras, escreveu Wittgenstein, 'só adquirem significado de suas aplicações no fluxo da vida; o signo, considerado separadamente de suas aplicações, parece morto, sendo no uso que ele ganha seu sopro vital'. As nossas expressões adquirirem diferentes funções, de acordo com o contexto no qual elas são empregadas, modificando-se, assim, o que se quer dizer com elas. A ideia fica mais clara pela comparação que Wittgenstein faz da linguagem com as ferramentas ou com as alavancas de uma locomotiva. Embora suas formas sejam semelhantes, as suas funções podem ser muito diversas. As ferramentas e alavancas só adquirem para nós um 'significado se soubermos para que servem, se soubermos como usá-las'. E uma mesma ferramenta pode ser usada de diferentes maneiras, de acordo com as circunstâncias". 
expressões linguísticas exercem em um contexto específico e com objetivos específicos. O significado pode, por conseguinte, variar dependendo do contexto em que a palavra é utilizada e do propósito deste uso. As palavras não são utilizadas primordialmente para descrever a realidade, como a semântica tradicional parecia supor, mas para realizar algum objetivo (...) A linguagem é sempre comunicação e a determinação do significado de uma palavra ou expressão depende da interpretação do objetivo de seu uso nesses contextos, não sendo, portanto, determinada de modo definitivo. Não podemos, então, generalizar e a ênfase na análise do contexto são alguns dos traços fundamentais que levam a classificar a concepção wittgensteiniana como pragmática (...) Quando se examina o uso concreto das expressões, percebe-se que em grande parte dos casos os equívocos resultam de confusões, falsas analogias, semelhanças superficiais, incapacidades de perceber distinções" 30 .

Esta concepção da linguagem como forma de ação, a título de registro, não é estranha ao Direito Administrativo.

Ao escrever sobre os fundamentos das primeiras elaborações teóricas do ato administrativo, Odete Medauar ${ }^{31}$, baseando-se na lição de Juan Alfonso Santamaria Pastor, Michel Stassinopoulos, Massimo Severo Giannini e de Eberhard SchmidtAssmann, aponta três linhas de pensamento como justificativa para o agir administrativo:

\footnotetext{
${ }^{30}$ MARCONDES, Danilo.A pragmática na filosofia contemporânea. Rio de Janeiro: Zahar, 2002, pp. 12-15. (Filosofia passo a passo, v. 5).

${ }^{31}$ Odete Medauar registra que para a primeira linha de entendimento, "o ato administrativo decorreria da separação de poderes, no sentido de que deveria haver um meio de exteriorização para cada um dos poderes estatais; o Poder Executivo, como Administração, se expressaria e diante o ato administrativo, que não se confunde com a lei, nem com a sentença. Nos primórdios da elaboração francesa, o ato administrativo decorreria da separação entre jurisdição e administração, no sentido de fugir à apreciação dos tribunais judiciários". Para a segunda orientação, segundo ela, "a base da concepção de ato administrativo se encontra no Estado de direito. A Administração, encartada no Pode Executivo, age submetendo-se à lei; as normas para edição dos atos administrativos refletem, em boa parte, a sujeição à lei. Para Stassinopoulos 'a sujeição do executivo à lei só se realiza com o advento do Estado de Direito (...) desde aí a ação do executivo recebe o nome de ato administrativo e adquire interesse jurídico especial, tornando-se objeto de um novo ramo jurídico; (...) precisando a noção de Estado de direito se pode definir o ato administrativo e determinar sua posição no conjunto das manifestações jurídicas do Estado atual'. Outra vertente dessa orientação, continua a autora, situa-se nas ideias de Otto Mayer, de elevada repercussão. O autor alemão, segundo ela, entrelaçava o ato administrativo ao principio da legalidade, decorrente do estado de Direito, em oposição aos atos emanados no período do Estado de Polícia ou Estado Absoluto. "E procurou efetuar um paralelo com a sentença judicial (...) Ainda como decorrência do Estado de Direito, veio a ideia de ato administrativo ser meio prévio à concretização de um intuito do governante (...) Na doutrina contemporânea, o alemão SchmidtAssmann se alinha a esta diretriz, afirmando que o ato administrativo 'proporciona, aos cidadãos, uma expectativa clara do que se vai leva a cabo sob a responsabilidade da Administração; refere-se à segurança jurídica do destinatário do ato (...)". Para a terceira linha de pensamento, ela conclui que "Ao mesmo tempo em que se apresenta como privilégio da Administração, dotado de força coativa, constitui via de acesso aos tribunais, possibilitando a defesa dos participantes quanto às atuações lesivas aos seus direitos. Harmut Maurer sublinha tal vínculo, notando que, na Alemanha, o ato administrativo só emergiu como noção individualizada nas leis sobre os tribunais administrativos, promulgadas após a Segunda Guerra mundial, as quais asseguravam a proteção jurisdicional contra todos os atos da administração". (MEDAUAR, Odete. Ato administrativo: origem, concepções, abrangência. In MEDAUAR, Odete; SCHIRATO, Vitor Rhein (coords). Os caminhos do ato administrativo. São Paulo: Revista dos Tribunais, 2012. pp. 18-19).
} 
aquelas que se sustentavam na noção de separação de poderes, aquelas que se orientavam pela ideia de Estado de Direito e uma outra que se elaborava na ideia da possibilidade de controle pelos tribunais judiciários ou administrativos. Vale dizer, para cada uma das precitadas linhas de pensamento sobre a teoria do ato administrativo a doutrina tinha em conta um fundamento para o agir administrativo.

É com o auxílio da noção da pragmática ${ }^{32}$ e a partir de uma verificação da experiência jurídico-administrativa da Administração Pública no Brasil, feita por alguns intérpretes do Brasil ${ }^{33}$, que o signo princípio de impessoalidade será confrontado com esta realidade constitucional com a finalidade de propor um significado jurídico deste princípio, reposicionando sua normatividade e distinguindo-o dos demais princípios constitucionais da Administração Pública.

Pode-se dizer, inicialmente, numa primeira intuição, que o princípio de impessoalidade parece tentar "dar sentido" 34 ao Brasil.

\footnotetext{
${ }^{32}$ Ainda sobre o tema, reporta-se à lição de Eros Roberto Grau: "A textura aberta da linguagem jurídica decorre do fato de nutrir-se da linguagem natural, na qual aqueles fenômenos se manifestam. Cumpre, ainda lembrar, todavia, que as línguas naturais não sobrevivem fundando-se exclusivamente em uma sintática e em uma semântica, mas também sobre uma pragmática. Isto é - como observa Umberto Eco [2001:43-44] 'baseando-se em regras de praxe, que levam em consideração as circunstâncias e os contextos de emissão, e estas mesmas regras de praxe estabelecem a possibilidade dos usos retóricos da língua, graças aos quais as palavras e construções sintáticas podem adquirir significados múltiplos (como ocorre, por exemplo, com as metáforas)" (GRAU, Eros Roberto. Porque tenho medo dos juízes (a interpretação/aplicação do direito e dos princípios). $6^{\mathrm{a}}$ edição refundida do ensaio e discurso sobre a interpretação/aplicação do direito. São Paulo: Malheiros, 2013. p. 144). Ainda sobre o tema, o mesmo autor: "O fato é que - como observa Karl Larenz [1983:83] - 'a linguagem jurídica deve ser considerado como um 'jogo de linguagem', no sentido que a essa expressão atribui Wittgenstein. O papel das palavras neste 'jogo' não é captável mediante uma definição, visto que, ao defini-las, estaremos a nos remeter ao seu significado em um outro 'jogo' de linguagem'”. O papel delas no jogo de linguagem, nestas condições, só poderá ser desvendado na medida em que passemos a participar do mesmo jogo. Desta participação no jogo decorre a possibilidade de compreendermos a linguagem jurídica - tarefa que é instrumentada pela dogmática -, o que importa, segundo Larenz, que, de fato, as palavras e expressões ganhem na linguagem jurídica sentidos mais precisos do que aqueles que tem na linguagem usual. É certo, pois, que, ainda que ambíguas e imprecisas, as palavras e expressões jurídicas expressam significações sempre determináveis" (Idem, ibidem. p. 145. grifos do autor).

${ }^{33}$ HOLANDA, Sério Buarque de. Raízes do Brasil. $26^{a}$ ed. São Paulo: Companhia das Letras, 1995.

${ }^{34}$ A palavra sentido é usada principalmente com três significados: como sensibilidade, como direção e como significação. Ou seja, é o que se sente, segue ou persegue, enfim o que se compreende. Estes dois últimos sentidos - aplicáveis ao nosso texto - estão ligados: o objetivo de uma ação também lhe dá um significado; ter um sentido é querer dizer ou querer fazer; o sentido supõe uma exterioridade, uma relação com outra coisa que não si mesmo (ideias colhidas do verbete Sentido - COMTE-SPONVILLE, André. Dicionário Filosófico .Eduardo Brandão (Trad.). São Paulo: Martins Fontes, 2003). O Brasil (ou melhor, a República Federativa do Brasil), nos termos da CR/1988, constituído como Estado Democrático de Direito, com seus fundamentos de cidadania, de dignidade da pessoa humana etc., tem objetivos, dentre eles, de construir uma sociedade livre, justa e solidária. Vale dizer, não estávamos sendo livres, justos e solidários. "Dar sentido" ao Brasil, no âmbito da atuação da Administração Pública, significa agir nessa direção preestabelecida pela Constituição de 1988, acompanhando o desenvolvimento desta atividade estatal, corrigindo erros e excessos, aprimorando-a finalisticamente. O professor JJ. Gomes Canotilho observa que "A constituição pretende 'dar forma', 'construir', 'conformar' um dado esquema de organização política. Mas conformar o quê? O Estado? A sociedade? Afinal qual é o referente da constituição?". Diz ele que o "artigo $16^{\circ}$ da Declaração dos Direitos do Homem e do Cidadão de 1789 é reiteradamente citado para identificar o 'núcleo duro' de uma constituição em sentido moderno". Entretanto, continua ele, que, "em geral, os autores deixam na sombra o
} 
Este trabalho acadêmico, a propósito, apresenta o problema do "sentido" do princípio de impessoalidade, segundo uma concepção finalística ou teleológica ${ }^{35}$, levando em conta elementos do conjunto histórico-jurídico-administrativo que o envolve. E nesta perspectiva a questão a ser examinada - o princípio - deixa de ser sobre dados de fatos a descrever, narrar ou alinhar no tempo, mas sim de apontar sinais ou indícios reveladores de um processo de mudança, no sentido de uma direção preestabelecida.

Sobre dar sentido às coisas, Alejandro Nieto ${ }^{36}$ observa que no interior do direito pulsa uma Razão Jurídica, “que não é um simples método, mas uma atitude cultural: algo assim como um código genético que permite a compreensão dele e que, ademais, programa seu desenvolvimento e condiciona sua operatividade". Essa expressão Razão Jurídica em seu sentido ordinário "tem um alcance causal: a razão de uma ação ou comportamento é a causa ou motivo que o produz, explica e justifica". Entretanto, pondera o professor espanhol que os especialistas manejam o sintagma por perspectivas muito distintas: objetiva, subjetiva ou ainda o conjunto das duas.

Este administrativista espanhol observa que para muitos o termo Razão Jurídica é a expressão de concreta racionalidade do direito, que o direito deve ser racional e se manifesta na Razão Jurídica. Entretanto, para ele, a Razão Jurídica tem uma natureza subjetiva, e que “inicialmente não forma parte do sistema, mas é uma 'reflexão' sobre o sistema, seguindo assim de perto o modelo kantiano da Razão e aproximando-se do que em termos modernos se chama também 'pensamento' ou 'discurso'. A Razão Jurídica, enquanto toma consciência ou reflexão, costuma ser racional certamente, mas não exclui elementos mais ou menos importantes de intuição e desde logo não prejulga a

referente da constituição". Aquele dispositivo, segundo o professor português, não fala em Estado, mas em sociedade: "A sociedade 'tem' uma constituição; a constituição é a constituição da sociedade" (CANOTILHO, J. J. Gomes. Direito Constitucional e Teoria da Constituição. $7^{\mathrm{a}}$ edição. Coimbra: Edições Almedina, 2003. pp. 87-88). (grifos do autor).

35 "O homem é um animal teleológico, que atua geralmente em função de finalidades projetadas no futuro. Somente quando se leva em conta a finalidade de uma ação é que se pode compreender o seu 'sentido"'. (BOBBIO, Norberto. A era dos direitos. Carlos Nelson Coutinho (Trad.) e apresentação de Celso Lafer. Rio de Janeiro: Elsevier, 2004. p. 68).

${ }^{36}$ ALEJANDRO NIETO. Crítica de la Razón Jurídica. Madrid: Editorial Trotta, 2007. pp. 22-24 (tradução nossa). Para o francês Jean-Andrès Arnaud, pondera Alexandro Nieto, "a razão jurídica é um referente: um dado externo que proporciona unidade e coerência a um sistema jurídico e que explica a racionalidade dele mesmo, de tal maneira que um sistema jurídico não racional é o que carece de razão (jurídica) ou não é congruente com ela. Inserida em um sistema jurídico, uma ou outro inseparáveis e interdependentes, com a consequência de que quando o sistema muda, tem de mudar também a Razão, e quando esta muda por causas externas, tem de mudar consequentemente o sistema jurídico como se transforma os frutos de uma parreira quando se introduz nela um enxerto novo (a imagem é minha, não de Arnaud). Em definitivo, portanto, a Razão Jurídica deste autor é rigorosamente objetiva, como um elemento a mais do sistema em que se integra". E para Giuseppe Carraci, "a Razão jurídica tem um sentido mais metodológico: é uma forma de entender e aplicar o Direito". 
racionalidade do sistema, já que nem sequer influencia diretamente sobre ele mesmo (...) Razão Jurídica (...) é uma faculdade humana que capacita para entender as coisas ou fenômenos, para dar-lhes sentido e para formar e ordenar os sistemas. Opera, portanto, com uma luz que facilita a compreensão do mundo exterior. Mas facilitar não significa necessariamente compreender. Mas todavia, quando a Razão Jurídica se desvia, termina dificultando e ainda impedindo a compreensão. Daí a importância da crítica da Razão Jurídica, que vem a ser (...) como uma tarefa de limpeza dos óculos que impedem a visão clara ou, se se quiser, como um ajuste da lente de observação".

Parafraseando Alejandro Nieto, no Direito Administrativo brasileiro pulsa uma Razão Jurídica crítica ${ }^{37}$ : o princípio de impessoalidade.

Continuando seu raciocínio, Alejandro Nieto faz, então, uma distinção entre a Razão Jurídica reta e a Razão Jurídica desviada. Aquela é "a que se autocrítica e critica a Razão Jurídica desviada, que se caracteriza, entre outras coisas, por sua indiferença diante da realidade e diante da história (...) vive, com efeito, fora da realidade como consequência de duas qualidades que a caracterizam: o normativismo e a dogmática (...) para esta Razão Jurídica unicamente existem normas, ainda que logo sejam classificadas, sistematizas e reelaboradas pela dogmática. Em definitivo, para ela, o Direito está formado, pois, pelas normas jurídicas estatais gerais e abstratas devidamente tratadas pela dogmática. A realidade não conta e os únicos que importam são as leis e os sistemas normativos.

Os juristas têm de se ocupar exclusivamente, por tanto, com as normas sem preocupar-se com o que acontece fora delas. Estudam, por exemplo, as regras do processo, sua coerência interna e suas eventuais contradições sem indicar nunca a realidade para comprovar se tais regras se cumprem ou não e passa por alto o fato de que as sentenças tardam em ditar-se seis anos e não os seis meses que determinam as leis; analisam cuidadosamente a legislação fiscal e não comprovam quem paga e quem não paga os impostos. A realidade, em suma, é para eles coisa de sociólogo ou de historiadores, não de juristas" ${ }^{38}$.

\footnotetext{
37 "Em geral, julgamos que a palavra 'crítica' significa ser do contra, dizer que tudo vai mal, que tudo está errado, que tudo é feio ou desagradável. Crítica é mau humor, coisa de gente chata ou pretensiosa que acha que sabe mais que os outros. Mas não é isso que essa palavra quer dizer. A palavra 'crítica' vem do grego e possui três sentidos principais: 1) capacidade para julgar, discernir corretamente; 2) exame racional de todas as coisas sem preconceito e sem pré-julgamento; 3 ) atividade de examinar e avaliar detalhadamente uma ideia, um valor, um costume, um comportamento, uma obra artística ou científica". (CHAUI, Marilena. Convite à Filosofia. $13^{\mathrm{a}}$ edição. São Paulo: Ática, 2006. p. 18).

${ }^{38}$ ALEJANDRO NIETO. Crítica de la Razón Jurídica. Madrid: Editorial Trotta, 2007. pp. 30-31 (tradução nossa). Antonio Cândido, na apresentação da $26^{a}$ edição de Raízes do Brasil de Sérgio Buarque de Holanda,
} 
Em outras palavras, o princípio de impessoalidade parece ser uma razão jurídica crítica que tende a aproximar a realidade constitucional da realidade fática ${ }^{39}$, possibilitando o conhecimento e o controle da atuação administrativa e o contínuo aprimoramento desta atividade e de seu controle para a concreção legitimada ${ }^{40}$ das finalidades públicas.

registra uma realidade nacional exemplificativa desta visão que poderíamos chamar de suficiência das leis: "Os modelos políticos do passado continuam como sobrevivência, pois antes se adequavam à estrutura rural e agora não encontram apoio na base econômica. Daí o aspecto relativamente harmonioso do Império, ao contrário da república, que não possui um substrato íntegro, como era de tipo colonial, Cria-se então um impasse, que é resolvido pela mera substituição dos governantes ou pela confecção de leis formalmente perfeita. Oscilando entre um extremo e outro, tendemos de maneira contraditória para uma organização administrativa ideal, que deveria funcionar automaticamente pela virtude impessoal da lei, e para o mais extremo personalismo, que a desfaz a cada passo". (HOLANDA, Sério Buarque de. Raízes do Brasil. $26^{\mathrm{a}}$ ed. São Paulo: Companhia das Letras, 1995. p. 18-19).

${ }^{39}$ Observa Carlos Roberto Siqueira Castro que, "De fato, segundo a tendência prevalente nos anos 70 e 80 do século passado, que ampliou a agenda intervencionista do Estado Social Democrático, o casuísmo constituinte, quase sempre solícito à catarse de aflições e interesses da sociedade civil, acolheu incontáveis proposições da social democracia participativa e pluralista - o que transformou o receituário constitucional, num conjunto assistemático de normas, princípios e programas, sujeitos a variadas possibilidades exegéticas e esquemas de aplicabilidade que animam a controvérsia entre os estudiosos e executores da Constituição. Com o alargamento da positivação constitucional das aspirações humanas em termos de mais liberdade e de mais igualdade, o grande desafio dos ordenamentos nacionais passou a ser o da efetividade das normas constitucionais - ou seja, a superação da distância a mediar o Direito da Constituição e a realidade que vigora à sombra da Constituição, vale dizer, entre o sein e solen constitucional. Tal se aplica com especial relevo às nações com paisagem social típica de Terceiro Mundo (concentração de renda, bolsões de miséria, analfabetismo, subnutrição, desleixo ambiental, dependência econômica e tecnológica, deficiência dos serviços públicos etc.) mas que, com justificada magnanimidade, incorporam em suas Leis Supremas o catálogo ampliado de direitos humanos segundo a tendência contemporânea, conforme exemplifica o caso brasileiro. Este desafio, consoante já pudemos observar, retrata a luta sem tréguas entre os valores da liberdade e os valores da igualdade, que constitui - na feliz expressão de Legas Y Lacamba - a essência do drama político de nossos dias. Aí residem as ilusões e virtudes do Estado de direito nos dias presentes, de acordo com a emblemática figuração de Jean-Louis". Sobre essa figuração, na nota de rodapé n. 31, acrescenta Carlos Roberto: "Para esse ilustre colega da Universidade de Montpellier, na França, o desafio da transformação em realidade do modelo constitucionalista idealizado do Estado contemporâneo condiciona sua própria legitimidade histórica e conceitual: 'Trata-se de adotar um procedimento crítico que se articula em torno de duas proposições: a vontade de criar um Estado de Direito representa uma utopia que constituiu um poderoso fator de legitimação do Estado, mas também um elemento gerador de desastrosas ilusões porque a realidade nunca correspondeu e não pode sem dúvida corresponder ao modelo ideal; a verdade é, em compensação, que a ideologia do Estado de Direito graças aos efeitos induzidos que ela produz, as necessidades que ela suscita, contém exigências que pressionam o Estado a dar alguma consistência à representação que ela oferece, sob pena de depor contra sua própria legitimidade" (CASTRO, Carlos Roberto Siqueira. Estudos de Direito Público em homenagem a Celso Antônio Bandeira de Melo. In FIGUEIREDO, Marcelo; PONTES FILHO, Valmir (orgs). ___. São Paulo: Malheiros, 2006. pp. 178179, tradução nossa).

${ }^{40}$ Poder acompanhar o agir administrativo, participar dele, controlá-lo, contribuir para seu aperfeiçoamento finalístico, poderá ser uma maneira eficaz de não apenas obter coesão social, mas conscientização dos deveres e poderes da Administração Pública na ordem constitucional democrática vigente. O Estado não é um fim em si mesmo. O Estado, "como sociedade política, tem um fim geral, constituindo-se em meio para que os indivíduos e as demais sociedades possam atingir seus respectivos fins particulares. Assim, pois, pode-se concluir que o fim do Estado é o bem comum, entendido este como o conceituou o Papa João XXIII, ou seja, o conjunto de todas as condições de vida social que consintam e favoreçam o desenvolvimento integral da personalidade humana (...) este busca o bem comum de um certo povo, situado em determinado território" (DALLARI, Dalmo de Abreu. Elementos de teoria geral do Estado. 26 a ed. São Paulo: Saraiva, 2007. p. 108). Diogo Freitas do Amaral sobre a encíclica deste Papa: “O que é, então, necessário - segundo o Papa João XXIII, a um mês e meio de sua morte - para que reine a paz na terra (pacem in terris)? De acordo 
Insistir no conceito deste princípio a partir de uma descrição do real - ser impessoal é ser imparcial, neutro, objetivo, não privilegiar gostos ou interesses pessoais, é não se desviar do fim público etc. - é manter o novel princípio constitucional da Administração Publica sem normatividade constitucional adequada ${ }^{41}$.

Em Teoria do Estado e da Constituição, Jorge Miranda afirma que o "Direito constitucional é a parcela da ordem jurídica que rege o próprio Estado enquanto comunidade e enquanto poder. É o conjunto de normas (disposições e princípios) que recortam o contexto jurídico correspondente à comunidade política como um todo e aí situam os indivíduos e os grupos uns em face dos outros e frente ao Estado-poder e que, ao mesmo tempo, definem a titularidade do poder, os modos de formação e manifestação da vontade política, os órgãos de que esta carece e os actos em que se concretiza"42.

Pois bem, este princípio parece estar diretamente ligado aos modos de formação e manifestação da vontade política em sua vertente administrativa.

Mais adiante, no item intitulado Perspectiva Metodológica, o professor português argumenta que o "maior vício do positivismo consiste na rendição do jurista perante o legislador, conjuntural ou não. O maior vício do formalismo reside em pedir à lógica mais do aquilo que pode dar. Pelo contrário, o Direito está acima e para além da lei; há valores suprapositivos a atender, únicos que lhe podem imprimir razão e permanência; a elaboração científica implica o apuramento de conceitos, mas não se esgota na sua concatenação; o sistema é confrontado com a mediação do problema; a lógica fornece processos de raciocínio, não fornece soluções.

De resto, o Direito é uma realidade cultural, indesligável das demais experiências humanas, e existe uma comunicação constante e dialéctica entre normas e fatos (...) No que à nossa disciplina em especial importa, haverá que contar com a directa

com o seu pensamento, são indispensáveis três condições: a subordinação dos homens e dos Estados ao Direito (cap. 1); uma relação das pessoas com os poderes públicos que salvaguarde e respeite os Direitos Humanos (cap. 2); e uma Comunidade Internacional baseada na verdade, na justiça, na caridade e na liberdade (caps. 3 e 4) (...) Tudo isto nos pode parecer, hoje em dia, um conjunto de valores e princípios óbvios: mas não o eram em 1963 (...) O problema de fundo que aqui se coloca é o de saber se é possível, ou não, continuar a acreditar na força política das ideais políticas. Por nós, entendemos sem qualquer dúvida que sim. Mas essa força irradia mais depressa ou mais devagar conforme o "espírito da época", conforme a capacidade de comunicação dos líderes e, ainda, conforme o grau de resistência de cada povo à inovação e à mudança" (AMARAL, Diogo Freitas do. História do Pensamento Político Ocidental. Coimbra: Almedina, 2011. p. 704).

${ }^{41}$ Em última análise, poder-se-ia dizer que manter o conceito ligado à descrição do real é conferir-lhe um sentido jurídico muito fraco. É, v.g., confundir-lhe com aquilo que se pretende (o cumprimento da lei). É imaginar que o agir administrativo preexiste (como presunção absoluta, a priori) ao ato propriamente praticado. É como se pudesse conceber a lei sendo suficiente para o agir administrativo, visão esta de conotação preconceituosa e prepotente, para não dizer tendenciosa, manipuladora, dominadora, arbitrária.

${ }^{42}$ MIRANDA, Jorge. Teoria do Estado e da Constituição. Coimbra: Editora Coimbra, 2002. p. 9. 
relação entre a Constituição e aquilo que se tem chamado realidade constitucional, ou realidade política, econômica, social e cultural que lhe subjaz, a que pretende aplicar-se e de que depende, em maior ou menor medida, o seu modo de vigorar (...)

Por último, sendo da função do Direito ajudar a resolver os problemas sociais (socioculturais, econômicos, políticos), a Ciência jurídica se torna uma ciência antecedente da ação. Com equilíbrio impende-lhe o dever de uma atitude crítica sobre o jus conditium em nome da justiça e da consciência colectiva, das situações concretas do país, da coerência do sistema e da técnica legislativa. Em Direito constitucional, cujas normas são e têm de ser tão aplicáveis à vida como quaisquer outras, algo haverá a dizer, alguns caminhos haverá a rasgar".

Esta nova ordem constitucional, com a inserção do princípio de impessoalidade, tende a rasgar caminhos... Caminhos para o agir da Administração Pública. 


\section{II - CONSIDERAÇÕES SOBRE A CONSTITUIÇÃO DA REPÚBLICA DE 1988}

2. 1. Uma premissa antropológica do direito compatível com a Constituição vigente

Pelo Direito $^{43}$, ao se estabelecer a personalidade jurídica, ligamos a infinitude de nosso universo mental à finitude de nossa experiência física, cumprindo em nós uma função antropológica de instituição da razão, não nos reduzindo a seres biológicos e mentais. Vale dizer, quando fazemos de cada um de nós um homo juridicus ${ }^{44}$ vinculamos as dimensões biológica e simbólica constitutivas do ser humano.

Negar esta função antropológica do Direito em nome de um pretenso realismo biológico, político ou econômico, é um ponto comum de empreendimentos totalitários ${ }^{45}$. Desqualificar o sujeito de direito para apreender o ser humano como simples unidade de conta e tratá-lo como gado ou a uma pura abstração, impondo o domínio da quantidade sobre a diversidade dos homens e das coisas, definitivamente vai de encontro com a norma constitucional que reconhece a dignidade da pessoa humana.

Alain Supiot ${ }^{46}$ argumenta que o sentido da vida não reside em nossos órgãos, mas vem necessariamente de uma referência que nos é exterior. O homem não é autossuficiente. Esta referência, segundo ele, garante, então, de algum modo um sentido e lugar ao homem. Assim, o Direito não pode ser compreendido apenas como produto de forças políticas ou econômicas, como uma técnica de poder a serviço dos poderosos. Isso tudo se mostra possível quando se deixa de lado a ideia de justiça. Sendo o homem um ser bidimensional, cuja vida social se desenvolve a um só tempo no terreno do ser e no dever ser, o Direito deve ser compreendido como uma obra plenamente humana, da qual participam aqueles que se dedicam a estudá-lo e não podem interpretá-lo sem levar em

\footnotetext{
43 “O direito não é uma simples representação da realidade, externa a ela, mas, sim, um nível funcional do todo social (...) o direito atua também como instrumento de mudança social (...) o direito não há de ser concebido exclusivamente como produto das relações econômicas, externo a elas, ou apenas como ideologia que oculta a natureza real das relações de produção, ou, ainda, tão somente como expressão da vontade da classe dominante e meio de dominação (...) Produto cultural, o direito é, sempre, fruto de determinada cultura. Por isso não pode ser concebido como fenômeno universal e atemporal" (GRAU, Eros Roberto. $O$ direito posto e o direito pressuposto. $8^{\mathrm{a}}$. ed. revista e ampliada. São Paulo: Malheiros, 2011. pp. 21-22).

${ }^{44}$ SUPIOT, Alain. Homo juridicus: ensaio sobre a função antropológica do Direito. Maria Ermantina de Almeida Prado Galvão (Trad.). São Paulo: WMF Martins fontes, 2007. pp. X-XII.

45 "O totalitarismo foi resultante da deformação da ideia de sociedade civil, devido ao predomínio de opções abstratas, que a desvincularam do processo histórico, sujeitando-a por inteiro ao arbítrio do Estado (...) a ideia de Estado deve ter como base a experiência histórica, sem prejuízo do que denomino 'invariantes axiológica', isto é, de certos valores que transcendem a história, ainda que dela emergentes, como é o caso do valor da pessoa humana e seu inseparável princípio fundante da liberdade". (REALE, Miguel. Questões de Direito Público. São Paulo: Saraiva, 1997. pp. 34-35).

${ }^{46}$ Idem, ibidem. pp. XIV-XXI.
} 
conta os valores por ele veiculados. Isso, contudo, não significa que se possa entender justiça como a maximização de utilidades individuais, que consiste em reportar toda regra a um cálculo de utilidade, que seria ao mesmo tempo a fonte e a medida de sua legitimidade. Entender o Direito sob essa perspectiva seria compreendê-lo senão e somente na perspectiva individual, dos direitos subjetivos, fazendo-o desaparecer como bem comum, que pressupõe a possibilidade de usufruto de direitos subjetivos num contexto comum e reconhecido por todos. Do contrário, o indivíduo não teria necessidade do Direito para ser titular de direitos. Aquele se resumiria numa lei única destrutível de todos contra todos.

Enfim, em alguma medida, o princípio de impessoalidade se mostra consentâneo com esta dimensão antropológica.

\section{2. Uma noção de Estado compatível com a ordem constitucional vigente}

O Estado, criação contínua da inteligência humana, é um poder político ${ }^{47}$ finalístico incessantemente renovado extraído da sociedade, que pretende, de modo refletido, dominar a si mesma e realizar seu destino temporal.

O Estado não deve ser considerado uma abstração ${ }^{48}$. É algo concreto, vivo, em construção.

\footnotetext{
47 "A palavra política vem do grego, onde polis era a cidade-Estado e o homem era considerado um zóon politikon (animal político), porque era feito para viver em sociedade (...) A política é uma actividade humana que diz respeito, sobretudo, à polis, quer dizer, ao Estado. Por um lado, é uma actividade humana de caráter competitivo, tal como a economia, o desporto ou a guerra. Os vencedores são os que conquistam ou mantém o Poder; vencidos são os que o perdem ou não o conseguem conquistar. Por outro lado, é uma actividade humana de caráter directivo, tal como a acção da direcção de uma escola, de um hospital ou de uma empresa; só que o seu âmbito é alargado a toda a polis. Podemos, assim, definir Política > - dentro das actividades humanas - como uma dupla actividade: a actividade de tipo competitivo que tem por objectivo a luta pelo Poder, bem como a actividade de tipo directivo que consiste em governar os povos" (AMARAL, Diogo Freitas do. História do Pensamento Político Ocidental. Coimbra: Almedina, 2011. p. 17).

${ }^{48}$ Jorge Luis Borges (Nuestro Pobre Individualismo. Inquisiciones/Outras Inquisiciones. Buenos Aires: Debolsillo, 2012. p. 193. (tradução nossa) registra que "o argentino, diferentemente dos americanos do Norte e de quase todos os europeus, não se identifica com o Estado. Pode-se atribuir isso à circunstância de que, neste país, os governos costumam ser péssimos ou ao fato geral de que o Estado é uma inconcebível abstração; ; o certo é que o argentino é um indivíduo, não um cidadão". Na nota de rodapé n. 1, o escritor argentino acrescenta: "O Estado é impessoal: o argentino apenas concebe uma relação pessoal. Por isso, para ele, roubar dinheiro público não é um crime. Comprovo um fato; não o justifico ou desculpo". Aqui se percebe que a expressão impessoal não tem o mesmo significado para o princípio em estudo. Algo semelhante, agora entre nós brasileiros, o registro de Raymundo Faoro: "Um aparente paradoxo: o Estado, entidade alheia ao povo, superior e insondável, friamente tutelador, resistente à nacionalização, gera o sentimento de que ele tudo pode e o indivíduo quase nada é. $\mathrm{O}$ ideal, utopicamente liberal, que afirma o domínio, a fiscalização e a apropriação da soberania de baixo para cima, base do regime democrático, esse ideal não perece, não obstante sua impotência". (FAORO, Raymundo. Os donos do poder: formação do patronato político brasileiro. $3^{\mathrm{a}}$ ed. rev. São Paulo: Globo, 2001. p. 452).
} 
O fenômeno político, sendo uma das manifestações do caráter social do homem, apresenta uma "dupla face" "49: a de fato que acontece na vida dos homens em relação entre si ou algum aspecto desta relação intersubjetiva, e a de realidade impregnada de valores.

Prosseguindo em sua lição, Jorge Miranda afirma que o fenômeno político "Parece ligar-se ao poder, ao poder político ou, na tradição clássica, à Civitas, à realização do Homem na Cidade e ao bem comum temporal. Há quem afirme a sua especificidade irredutível e há quem, pelo contrário, o reconduza a fenômenos de distinta natureza.

Uns acentuam elementos espirituais, v.g., as condições de legitimidade dos governantes; outros concentram-se em elementos materiais, v.g., a subordinação dos mais fracos aos mais fortes ou o domínio exercido por uma classe social e baseado na diferenciação económica. Uns recorrem a explicações contratualistas, outros a explicações institucionalistas, outros ainda, por exemplo, a explicações funcionalistas".

Esta dupla face do fenômeno político, contudo, revela também a ambiguidade do Estado. E esta sua característica é apresentada de forma peculiar por Georges Burdeau ${ }^{50}$ :

"Base de um Poder desencarnado, mas ao mesmo tempo provedor do poder dos homens que governam em seu nome, o Estado é um Jano de quem uma face, a que é serena, reflete o reinado do direito e a outra, atormentada se não retorcida, é marcada por todas as paixões que animam a vida política.

Essa ambiguidade estar na origem dos juízos contraditórios de que é objeto o Estado é evidente. Mas, o que importa compreender é que ela lhe é essencial. O oráculo diz o direito, mas pela boca dos homens. Suas decisões são enobrecidas pela autoridade prestigiosa que se vincula à norma jurídica, mas sua substância é nutrida dos interesses, das ambições, das ideologias de que as forças políticas que se enfrentam na sociedade extraem um poder incessantemente renovado. É que, apesar de ter domesticado o Poder inserindo-o no Estado, nem por isso o pensamento mudou seus fins. É sempre ele que proclama a regra e coage a respeitá-la. E essa regra, quem, a não ser os governantes, poderia fixar-lhe o conteúdo? A idéia do Estado mostra-se assim um artifício graças ao

\footnotetext{
${ }^{49}$ MIRANDA, Jorge. Teoria do Estado e da Constituição. Coimbra: Editora Coimbra, 2002. p. 7.

${ }^{50}$ BURDEAU, Georges. O Estado. Maria Ermantina de Almeida Prado Galvão (Trad.). São Paulo: Martins Fontes, 2005. pp. 35-37. Sobre ser um artifício, Georges Burdeau esclarece: "Esforço de vontade, o Estado é artifício. Artifício, não no sentido em que o entendia, com Rousseau, a filosofia do século XVIII, pois o Estado cria um clima indispensável à realização da personalidade humana; mas artifício no sentido de que não é dado como um fenômeno natural, mas deve ser construído pela inteligência humana” (p. 37).
} 
qual as vontades que, tanto em sua origem como em sua substância, são vontades humanas que podem ser imputadas a uma entidade. Mediante essa operação que as despersonaliza, essas vontades adquirem um significado e uma autoridade novos: tornam-se vontades do Estado e, por isso, não podem ser contestadas sem que seja questionado o ordenamento jurídico global da coletividade. Por certo o Estado não cria o direito, mas expressa seus imperativos tais como estes se impõem em dada sociedade em dado momento".

Discorrendo sobre o nascimento do Estado, trazendo também uma visão antropológica a respeito, o professor francês traz um alerta: "Associamos o nascimento do Estado à finalização de toda uma série de fatores que em certo momento da evolução dos grupos sociais incitam a pensar no fundamento da organização política. Só que não devemos nos enganar sobre o caráter dessas forças cuja resultante é o Estado. Elas não são nem um pouco espontâneas como o é o movimento que impele os homens a se reunirem em sociedade; nem sequer são favorecidas pelo instituto ou pelos gostos de cada um, pois, se os homens se deixassem levar por sua inclinação natural, certamente não seria para a forma estatal que a vida coletiva se orientaria. Essas forças são, ao contrário, a expressão de uma vontade refletida; são uma reação contra impulsos naturais, uma resistência da inteligência aos convites que emanam das partes obscuras de nossa natureza. Dessa maneira, fica bem claro que o Estado é de uma essência totalmente diferente daquela do clã ou da tribo, pois, ao passo que estes procedem de uma associação espontânea dos indivíduos, o Estado, ao contrário, para se formar, necessita que cada qual exerça sobre si próprio um controle, reflita nas exigências da ordem jurídica e, finalmente, pense o Estado como o instrumento de realização de nosso destino temporal. Nesse sentido o Estado é, acima de tudo, o efeito da vontade agindo contra aspirações, inclinações, indiferenças do indivíduo propenso a deixar-se docilmente arrastar por seu instinto egoísta”.

Enfim, o Estado é criação humana. E a esse respeito, o professor francês conclui que "Fica claro que, uma vez que o Estado é criado pelo espírito, ele o é, como todas as coisas criada pelo talento humano, em conformidade com um certo ideal. Quando os indivíduos pensam o Estado, é mesmo vendo nele uma instituição destinada a funcionar segundo certas normas e visando uma finalidade que aceitam. O Estado reflete-lhes o pensamento.

E é por isso que, se o Estado é artifício, nem por isso é concebido de uma vez por todas. É, ao contrário, uma criação contínua que exige por parte dos indivíduos um esforço de pensamento pelo qual seus mecanismos e suas atividades adquirem seu verdadeiro sentido. É necessário que, através do policial, vejam o poder público, que a 
declaração de imposto evoque para eles os serviços sociais mantidos pelo fisco, que se sintam envolvidos pelas negociações do ministro de Relações Exteriores, que o voto de uma lei ou a adoção do Plano não lhes pareça somente um procedimento, mas signifique a seus olhos um compromisso assumido em nome deles; em suma, é preciso que associem as manifestações externas do poder à idéia de um projeto coletivo que o grupo formula para dominar seu destino. Trata-se de um plebiscito cotidiano, que vai muito além das personalidades que dele se beneficiam, pois seu objeto é confirmar o Estado em seu papel de expressão da consciência política de grupo, ou seja, de instrumento pelo qual, com todos os erros que tal empreendimento comporta, a sociedade afirma o domínio de si mesma".

Percebe-se, então, duas perspectivas de um mesmo fenômeno que não pode ser separada para que se possa manter a unidade deste sistema de convivência em permanente construção.

Retomando a lição de Jorge Miranda, "Nos nossos dias, toda a problemática surge posta, directa ou indirectamente, a respeito do Estado. É o Estado organização de governantes e de governados ou comunidade dos cidadãos - que se patenteia a mais clara luz, pois o Estado constitui a sociedade política característica dos últimos séculos e, decerto, a mais complexa, a mais sólida e a mais expansiva da história.

Conhecem-se também duas perspectivas primárias das quais o Estado pode ser encarado: como Estado-comunidade e como Estado-poder; como sociedade, de que fazemos parte e em que se exerce um poder para a realização de fins comuns, e como poder político manifestado através de órgãos, serviços e relações de autoridade. Mas estas perspectivas não devem cindir-se, sob pena de se perder a unidade de que se depende a subsistência do político; e essa unidade é, para o que aqui interessa, uma unidade jurídica, resulta de normas jurídicas" ${ }^{\circ 1}$.

Enfim, o princípio de impessoalidade se mostra consentâneo com esta realidade de Estado.

\footnotetext{
${ }^{51}$ MIRANDA, Jorge. Teoria do Estado e da Constituição. Coimbra: Editora Coimbra, 2002. pp. 7-8.
} 


\section{3. A Constituição da República e o processo de constitucionalização}

A Constituição da República de 1988, fruto de um processo de constitucionalização $^{52}$, passando para o centro do ordenamento jurídico, reposicionou o homem no ordenamento jurídico nacional ${ }^{53}$. À maneira de uma revolução que modifica seu paradigma de compreensão do mundo, ela tira do centro do sistema o Estado e seus agentes e coloca a pessoa humana, o cidadão, a sociedade. E não o faz sem fundamentos e objetivos e reconhecimento de direitos e organização estrutural para a realização deles.

Fundamentando-se $\left(\mathrm{CR}\right.$, art. $\left.1^{\circ}\right)$ nas noções de soberania, de cidadania, de dignidade da pessoa humana, de valores sociais do trabalho e de livre iniciativa e pluralismo político, a República Federativa do Brasil tem (CR, art. $3^{\circ}$ ) como objetivos fundamentais a construção de uma sociedade livre, justa e solidária, a garantia do desenvolvimento nacional, a erradicação da pobreza e da marginalização e a redução das desigualdades sociais e regionais e a promoção do bem de todos, sem preconceitos de origem, raça, sexo, cor, idade e quaisquer outras formas de discriminação.

Reafirmando e ampliando direitos e garantias fundamentais, a Constituição de 1988 dispõe em seu art. 5, caput, que "Todos são iguais perante a lei, sem distinção de qualquer natureza, garantindo-se aos brasileiros e aos estrangeiros residentes no País a inviolabilidade do direito à vida, à liberdade, à igualdade, à segurança e à propriedade, nos seguintes termos:".

Ao especificar estes termos, a Constituição assegura inúmeros direitos e garantias, dentre eles, por exemplo, "ninguém será obrigado a fazer ou deixar de fazer alguma coisa senão em virtude de lei"; "é assegurado, o direito de resposta proporcional ao agravo, além da indenização por dano material, moral ou à imagem"; "ninguém será privado de direitos por motivo de crença religiosa ou de convicção filosófica ou política, salvo se as invocar para eximir de obrigação legal a todos imposta e recusar-se a cumprir

\footnotetext{
52 “A Constituição é o instrumento por meio do qual os sistemas democrático e de direitos fundamentais se institucionalizam no âmbito do Estado. O processo por meio do qual tais sistemas espraiam seus efeitos conformadores por toda a ordem jurídico-política, condicionando e influenciando os seus diversos institutos e estruturas, tem sido chamado de constitucionalização do direito" (BINENBOJM, Gustavo. Novos paradigmas do Direto Administrativo - A Constitucionalização do Direito Administrativo no Brasil: um inventário de avanços e retrocessos. IN BARROSO, Luís Roberto (org.). A reconstrução democrática do direito público no Brasil. Rio de Janeiro: Renovar, 2007. p. 526).

53 “A passagem da Constituição para o centro do ordenamento jurídico representa a grande força motriz das mudanças de paradigmas do direito administrativo na atualidade. A supremacia da Lei Maior propicia a impregnação da atividade administrativa pelos princípios e regras naquela previstos, ensejando uma releitura dos institutos e estruturas da disciplina pela ótica constitucional" (Idem, ibidem. p. 526).
} 
prestação alternativa, fixada em lei”; "é livre a expressão da atividade intelectual, artística, científica e de comunicação, independentemente de censura ou licença"; "são invioláveis a intimidade, a vida privada, a honra e a imagem das pessoas, assegurado o direito a indenização pelo dano material ou moral decorrente de sua violação"; "a casa é asilo inviolável do indivíduo, ninguém nela podendo penetrar sem consentimento do morador, salvo em caso de flagrante delito ou desastre ou para prestar socorro, ou, durante o dia, por determinação judicial”; "é assegurada a todos o acesso à informação e resguardado o sigilo da fonte, quando necessário ao exercício profissional”; "a lei estabelecerá o procedimento para desapropriação por necessidade ou utilidade, ou por interesse social, mediante justa e prévia indenização em dinheiro, ressalvados os casos previstos nesta Constituição"; "no caso de iminente perigo público, a autoridade competente poderá usar de propriedade particular, assegurada ao proprietário indenização ulterior, se houver"; "todos têm direito a receber dos órgãos públicos informações de seu interesse particular, ou de interesse coletivo ou geral, que serão prestadas no prazo da lei, sob pena de responsabilidade, ressalvadas aquelas cujo sigilo seja imprescindível á segurança da sociedade e do Estado"; "são a todos assegurados, independentemente de taxas: a) o direito de petição aos Poderes Públicos em defesa de direito ou contra ilegalidade ou abuso de poder; b) a obtenção de certidões em repartições públicas, para defesa de direitos e esclarecimento de situações de interesse pessoal"; "a lei não excluirá da apreciação do Poder Judiciário lesão ou ameaça a direito"; "aos litigantes, em processo judicial ou administrativo, e aos acusados em geral são assegurados o contraditório e ampla defesa, com os meios e recursos a ela inerentes"; "são inadmissíveis , no processo, as provas obtidas por meios ilícitos"; "conceder-se-á mandado de segurança para proteger direito líquido e certo, não amparado por habeas corpus ou habeas data, quando o responsável pela ilegalidade ou abuso de poder for autoridade pública ou agente de pessoa jurídica no exercício de atribuições”; “conceder-seá habeas data: a) para assegurar o conhecimento de informações relativas à pessoa do impetrante, constantes dos registros ou bancos de dados de entidades governamentais ou de caráter público; b) para retificação de danos, quando não se prefira fazê-los por processo sigiloso ou administrativo"; "qualquer cidadão é parte legítima para propor ação popular que vise a anular ato lesivo ao patrimônio público ou de entidade de que o Estado participe, à moralidade administrativa, ao meio ambiente e ao patrimônio histórico e cultural, ficando o autor, salvo comprovada má-fé, isento de custas judiciais e do ônus da sucumbência"; "o Estado prestará assistência jurídica integral e gratuita aos que 
comprovarem insuficiência de recurso"; "a todos, no âmbito judicial e administrativo, são assegurados duração do processo e os meios que garantam a celeridade de sua tramitação".

Se em relação aos direitos e garantias o legislador constitucional de 1988 foi generoso, no que diz respeito à Administração Pública ${ }^{54}$ ele inovou na ordem constitucional, dando-lhe tratamento mais detalhado ${ }^{55}$, com estabelecimento de sua principiologia $^{56}$.

Enfim, nesse processo de constitucionalização, o principio de impessoalidade ocupa possível relevante em relação ao agir administrativo.

\footnotetext{
54 “No Brasil, desde a primeira Constituição - a Imperial de 824 -, havia referências à Administração Pública, basicamente à Administração das Províncias, pois sendo Estado Unitário cuidou o constituinte de estabelecer diretrizes mínimas também para as unidades administrativas em que se dividia o território. Claro se fez, entretanto, não ser este tema constitucional. Por isso, a Carta de Lei do Império, semi-rígida em sua caracterização, permitia que as modificações nesta matéria pudessem ser feitas por lei ordinária (art. 178). A partir da Constituição da república de 1981, o constitucionalismo positivo brasileiro referiu-se sempre a alguns temas da Administração Pública, basicamente aqueles referentes aos cargos e funcionalismo públicos (art. 73 da constituição de 1981, incluído o Título IV - Dos cidadãos Brasileiros; arts. 168 a 173, da Constituição de 1934, que introduziu um Título - VII - sobre os funcionários públicos , bem como estabeleceu normas gerais de administrados dos Estados e Município da Federação; arts. 156 a 159 da carta de 1937; arts. 184 a 194, da Constituição de 1046, sob o título VIII - Dos Funcionários Públicos - , sendo de se salientar ter aquela Lei Maga introduzido a infeliz prática de se altera o regime jurídico dos funcionários públicos em exercício na data da promulgação do texto constitucional, concedendo-lhes a condição de efetivos ou estáveis nos cargos, cujas funções estivessem sendo por eles desempenhada - art. 23, do Ato das Disposições Constitucionais Transitórias; arts. 95 a 106,d a Carta de 1967 e arts. 177 a 180, do Ato das disposições Constitucionais Gerais e Transitórias; arts. 97 a 111, da Emenda Constitucional n. 1/69, bem como arts. 194, 196 e 197, do Ato das Disposições Constitucionais Transitórias daquele documentos). É certo que não apenas aqueles temas foram objeto de balizamento constitucional, tendo havido, em todas as Constituições repúblicas brasileiras, por exemplo, previsões sobre atividades administrativas específicas, mormente aquelas que concerniam ao combate à seca no Nordeste brasileiro, aos planos de defesa contra os seus efeitos, a planos de valorização econômica da Amazônia, dentre outras. Desde a Constituição brasileira de 1934, estabeleceu-se norma sobre a exploração de alguns serviços públicos, como o da energia hidrelétrica (art. 12, das disposições Transitórias, do Código Supremo de 1934; art. 146, da Carta de 1937; arts. 150, da Constituição de 1946; arts. 160 e 163 , $\S 2^{\circ}$, da Carta de 1967; arts. 167 e $170, \S \S 1^{\circ}$ e $2^{\circ}$, da emenda n. 1/69 à Carta de 1967)". (ROCHA, Cármen Lúcia Antunes. Princípios constitucionais da administração pública. , Belo Horizonte: Del Rey, 1994. pp. 64-65).

${ }_{56}^{55}$ A Constituição de 1988 traz inúmeras disposições sobre a Administração Pública do art. 37 ao art. 43.

${ }^{56}$ O professor Inocêncio Mártires Coelho registra que a Administração Pública passa a ter um sistema constitucional: "O sistema constitucional da Administração Pública brasileira foi estabelecido com um conjunto de princípios, subprincípios e algumas regras, considerados necessários à garantia de sua ordem $\mathrm{e}$ unidade internas, a fim de que as entidades e órgãos possam atuar, na maior harmonia possível, para a consecução dos seus fins. Assim, a discussão sobre a Administração Pública, do prisma constitucional, importa a análise das entidades e órgãos que dão vida à prática administrativo-constitucional brasileira, bem como dos principais problemas por ela enfrentados na condução das atividades estatais de caráter administrativo" (MENDES, Gilmar Ferreira; COELHO, Inocêncio Mártires; BRANCO, Paulo Gustavo Gonet. Curso de Direito Constitucional. $2^{\mathrm{a}}$ ed., revisada e atualizada. São Paulo: Saraiva, 2008. p. 826).
} 
2. 4. A Constituição de 1988: Estado Democrático de Direito e a sociedade

A República Federativa do Brasil ${ }^{57}$, conforme já se salientou, se constitui em Estado Democrático de Direito e tem como fundamentos a soberania, a cidadania, a dignidade da pessoa humana, os valores sociais do trabalho e da livre iniciativa e o pluralismo político.

Como se percebe o reconhecimento da noção de Estado de Direito se dá de modo expresso pela Constituição da República. Cuida-se, na verdade, do princípio do Estado de Direito. E dele podem ser sintetizados, na lição de J.J. Gomes Canotilho ${ }^{58}$, independentemente de suas densificações e concretizações, alguns pressupostos subjacentes: a juridicidade, a constitucionalidade e os direitos fundamentais.

O princípio do Estado de Direito, na lição do constitucionalista português, "é, fundamentalmente, um princípio constitutivo, de natureza material, procedimental e formal (...) que visa dar respostas ao problema do conteúdo, extensão e modo de proceder da actividade do estado. Ao 'decidir-se' por um estado de direito a constituição visa conformar as estruturas do poder político e a organização da sociedade segundo uma medida do direito. Mas o que significa direito nesse contexto? A clarificação do sentido de <<direito >> ou $<<$ medida do direito $>>$ é, muitas vezes, perturbada por précompreensões (ideológicas, religiosas, políticas, económicas, culturais), mas, de forma alguma intencionalmente expositiva, podemos assinalar algumas premissas básicas. $\mathrm{O}$ direito compreende-se como um meio de ordenação racional e vinculativa de uma comunidade organizada e, para cumprir esta função ordenadora, o direito estabelece regras e medidas, prescreve formas e procedimentos e cria instituições. Articulando medidas ou regras materiais com formas e procedimentos, o direito é, simultaneamente, medida material e forma da vida colectiva (K. Hesse). Forma e conteúdo pressupõem-se reciprocamente: como meio de ordenação racional, o direito é indissociável da realização da justiça, da efectivação de valores políticos, econômicos, sociais e culturais; como forma, ele aponta para a necessidade de garantias jurídico-formais de modo a evitar acções e comportamentos arbitrários e irregulares de poderes públicos”.

\footnotetext{
${ }^{57}$ É o que dispõe o art. $1^{\text {o }}$ da Constituição da República.

${ }^{58}$ CANOTILHO, J. J. Gomes. Direito Constitucional e Teoria da Constituição. $7^{\text {a }}$ edição. Coimbra: Edições Almedina, 2003. pp. 243-249.
} 
É nesse contexto que citando Jhering, J.J. Gomes Canotilho ${ }^{59}$ observa que "a forma é inimiga jurada do arbítrio e irmã gêmea da liberdade" e acrescenta que "como medida e forma colectiva, o direito compreende-se no sentido de uma ordem jurídica global que 'ordena' a vida política (especificamente através do direito constitucional), regula relações jurídicas civis e comerciais (através do direito civil e comercial), disciplina o comportamento da administração (direito administrativo), sanciona actos ou comportamentos contrários ou 'desviantes' da ordem jurídica, designadamente por lesões graves dos bens constitucionalmente protegidos (direito criminal), cria formas, procedimentos e processos para 'canalisar, em termos jurídicos', a solução dos conflitos de interesse públicos e privados (direito processual, direito procedimental)".

Vale dizer, o direito como forma e conteúdo, visando à ordenação racional e vinculativa de uma comunidade organizada - e.g., ao disciplinar o Direito Administrativo -, se opõe à arbitrariedade dos agentes do poder e visa a garantir a liberdade dos cidadãos.

Ainda sobre juridicidade, cumpre lembrar a lição de Gustavo Binenbojm, no sentido de que a "constitucionalização do direito administrativo convola a legalidade em juridicidade administrativa. A lei deixa de ser o fundamento único e último da atuação da Administração Pública para se tornar apenas um dos princípios do sistema de juridicidade instituído pela Constituição. Como registra corretamente Juarez Freitas, 'esta parece ser a melhor postura, em vez de absolutizações incompatíveis com o pluralismo nuclearmente caracterizador dos Estados verdadeiramente democráticos, nos quais os princípios absolutos são usurpadores da soberania da constituição como sistema. Com efeito, a soberania da Constituição, de que fala Gustavo Zagrebelski, deve ser vista, antes de tudo, como soberania de princípios à procura de síntese no intérprete constitucional"60 .

Ao lado deste seu aspecto de juridicidade, aparece a ideia de Estado Constitucional. Ou seja, o Estado de Direito é um Estado Constitucional - aqui a lição é de Gomes Canotilho61 -, que pressupõe "a existência de uma constituição normativa estruturante de uma ordem jurídico-normativa fundamental vinculativa de todos os poderes.” Em outras palavras, a Constituição confere à ordem estatal e aos atos dos poderes públicos medida e forma.

\footnotetext{
${ }^{59}$ CANOTILHO, J. J. Gomes. Direito Constitucional e Teoria da Constituição. $7^{\mathrm{a}}$ edição. Coimbra: Edições Almedina, 2003. p. 244.

${ }^{60}$ BINEMBOJM, Gustavo. Novos paradigmas do Direto Administrativo - A Constitucionalização do Direito Administrativo no Brasil: um inventário de avanços e retrocessos. IN BARROSO, Luis Roberto. $A$ reconstrução democrática do direito público no Brasil. Rio de Janeiro: Renovar, 2007. p. 527.

${ }^{61}$ Idem, ibidem, p. 245.
} 
Assim, a Constituição, conforme esclarece o professor português, não é apenas "uma simples lei incluída no sistema ou no complexo normativo-estadual. Trata-se de uma verdadeira ordenação normativa fundamental dotada de supremacia - supremacia da constituição - e é nesta supremacia normativa da lei constitucional que o 'primado do direito' do estado de direito encontra uma primeira e decisiva expressão".

Destes princípios de constitucionalidade e de supremacia da Constituição decorrem os princípios da vinculação do legislador e o de todos os atos estatais à Constituição. Este último, na lição de J.J. Gomes Canotilho ${ }^{62}$, “exige, desde logo, a conformidade intrínseca e formal de todos os actos dos poderes públicos (...) Mesmos os actos não normativos diretamente densificadores de momentos políticos da constituição actos políticos - devem sujeitar-se aos parâmetros constitucionais e ao controlo (político ou jurídico) da sua conformidade com as normas da Constituição".

Por fim, atento aos fundamentos da Constituição da República - em especial ao da dignidade da pessoa humana -, não deve haver dúvida de que nossa Constituição reconhece uma base antropológica constitucionalmente estruturante do Estado de Direito.

Atento ao reconhecimento dos direitos fundamentais (CR, art. $\left.5^{\circ}\right)$, inferese - e aqui a lição também é de J.J. Gomes Canotilho ${ }^{63}$ - “a raiz antropológica se reconduz ao homem como pessoa, como cidadão, como trabalhador e como administrado".

Interessa-nos, neste trabalho sobre princípio de impessoalidade, o reconhecimento da extensão da dignidade da pessoa humana às pessoas dos administrados: a proteção do cidadão em sua relação com a Administração Pública. Entendida aqui tanto a situação em que ela age de ofício como quando ela age de modo provocado.

O caráter democrático do Estado brasileiro está expressamente reconhecido no parágrafo único do art. $1^{\text {o: }}$ "Todo o poder emana do povo, que o exerce por meio de seus representantes eleitos, ou diretamente, nos termos desta Constituição".

Poder-se-ia cogitar de que nossa democracia estaria limitada à possibilidade de escolha dos governantes. Mas não é assim. Referido dispositivo conjugado com outros dispositivos constitucionais - e.g., art. $3^{\circ}$ e art. $5^{\circ}$ da CR - é a confirmação da positivação do princípio democrático entre nós: é mais do que um método ou técnica para escolha dos governantes, porquanto atua como impulso dirigente da

\footnotetext{
${ }^{62}$ BINEMBOJM, Gustavo. Novos paradigmas do Direto Administrativo - A Constitucionalização do Direito Administrativo no Brasil: um inventário de avanços e retrocessos. IN BARROSO, Luis Roberto. A reconstrução democrática do direito público no Brasil. Rio de Janeiro: Renovar, 2007. p. 246.

${ }^{63}$ Idem, ibidem, 248.
} 
sociedade, como informador do Estado e da sociedade, como princípio organizador da titularidade e exercício do poder e controle deste poder.

Com o advento da Constituição da República de 1988 o Direito passou a ocupar um espaço cada vez maior no debate público brasileiro e, por conseguinte, também o papel do Estado - agora Democrático ${ }^{64}$, ou seja, o regime do poder visível, na expressão de Norberto Bobbio ${ }^{65}$ - para a construção de uma sociedade fraterna ${ }^{66}$, pluralista e sem preconceitos. De fato ela já prenunciava isso ao apontar, como objetivos fundamentais da República Federativa do Brasil ${ }^{67}$, a construção de uma sociedade livre, justa e solidária, a garantia do desenvolvimento nacional, a erradicação da pobreza e a marginalização e da redução das desigualdades sociais e regionais e a promoção do bem de todos, sem preconceitos de origem, raça, sexo, cor, idade e quaisquer outras formas de discriminação.

Impulsionado por uma verdadeira renovação institucional, este processo constitucional regulou diversos e complexos campos da atividade social. Estabeleceu-se uma nova ordem econômica e financeira ${ }^{68}$, fundada na valorização do trabalho humano e na livre iniciativa, com o fim de assegurar a todos existência digna, conforme os ditames da justiça social, e uma nova ordem social, regulando diversos campos da atividade social $^{69}$ : seguridade social, englobando saúde, previdência social e assistência social, e educação, cultura e desportos, além de ciência e tecnologia, comunicação social, meio ambiente, família, criança, adolescente e idoso e índios. Esta nova realidade impõe que

${ }^{64}$ O Estado, embora titular deste dever constitucional, não é o único a se desincumbir deste desejo constitucional. A sociedade também exerce este encargo. Aliás, é ela quem, por meio de seus representantes, instituiu este Estado Democrático, conforme se registra no preâmbulo da Constituição de 1988. Além dos mecanismos de se poder chegar ao poder (CR, art. 14, caput), poderá de alguma forma exercê-lo por outros mecanismos como o plebiscito, o referendo, a iniciativa popular, mas também por meio de audiências públicas, participação em conselhos de empresas públicas etc. (CR, art. 39, 58, §2º inc. II). Cumpre, nesse momento, registrar a lição de Gomes Canotilho: "Afastando-se das conotações restritivas de democracia, a Constituição alicerçou a dimensão participativa como outra componente essencial da democracia. As premissas antropológico-políticas da participação são conhecidas: o homem só se transforma em homem através da autodeterminação e a autodeterminação reside primariamente na participação política (orientação de 'input')" (CANOTILHO, J. J. Gomes. Direito Constitucional e Teoria da Constituição. $7^{\mathrm{a}}$ edição. Coimbra: Edições Almedina, 2003. p. 1159).

${ }^{65}$ Referindo-se o "regime do poder visível", que bem se amolda ao princípio de impessoalidade, Norberto Bobbio registra: "Como regime do poder visível, a democracia nos faz imediatamente pensar na imagem, transmitida pelos escritores políticos de todos os tempos que se inspiraram no grande exemplo da Atenas de Péricles, de 'ágora' ou da 'ecclesia', isto é, da reunião de todos os cidadãos num lugar público com o objetivo de apresentar e ouvir propostas, denunciar abusos ou fazer acusações, e de decidir, erguendo as mãos ou com cacos de terracota, após terem apreciado os argumentos pró e contra apresentados pelos oradores. Quando o povo estava reunido, escreve Glotz, o arauto amaldiçoava quem quer que procurasse enganar o povo, e para que os demagogos não abusassem de suas artes oratórias a assembléia permanecia todo o tempo sob o 'olhar' de deus (destaque-se esta referência ao ato de "ver')" (BOBBIO, Norberto. $O$ futuro da democracia. Marco Aurélio Nogueira (Trad.). São Paulo: Paz e Terra, 2000 p. 98).

${ }^{66}$ Veja-se o preâmbulo da Constituição.

${ }^{67}$ Estes objetivos estão dispostos no art. $3^{\circ}$, da Constituição da República.

${ }^{68}$ Vejam-se os art. 170 a 192 da Constituição da República.

${ }^{69}$ Vejam-se os art. 194 a 232 da Constituição da República. 
qualquer questão relevante aos destinos do país passe pelo crivo do exame jurídico e leve em consideração as regras e princípios trazidos pela Constituição de 1988.

A promulgação da Constituição e o fim de um regime de ditadura alteraram completamente a relação da sociedade brasileira com suas instituições. Estabelecido o regime democrático, o Direito passa a não ser mais um instrumento estatal de poder alheio ao controle social. Surge a possibilidade de a sociedade controlar, resistir ou ainda criticar o poder, criticar o exercício do poder sob várias perspectivas. Com o Estado de Direito as ações do poder passam a ser formalizadas e, assim, viabilizam o autocontrole, o controle dos outros poderes ou o controle social do exercício do poder.

Nesse contexto, levando-se em conta a posição do Estado e sua composição para a consecução destes objetivos e os mecanismos de controle e participação popular, a Administração Pública passa a ter também relevante papel na construção desta sociedade.

A realidade jurídica advinda com a nova ordem constitucional, contudo, não rompeu totalmente com a realidade jurídico-administrativa então vigente ${ }^{70}$. Desde então concepções do antigo regime ${ }^{71}$ convivem com novos princípios da Constituição de

${ }^{70}$ O professor José Afonso da Silva, observou que a Constituição de 1967 sofreu poderosa influência da Constituição de 1937, preocupada com a segurança nacional, de acordo com a doutrina geopolítica de interesse dos Estados unidos no contexto da Guerra Fria; deu mais poderes à União e ao Presidente da República; reformulou, em termos mais nítidos o Sistema Tributário Nacional e a discriminação de rendas, ampliando a técnica do Federalismo Cooperativo; reduziu a autonomia individual, permitindo a suspensão de direitos e garantias constitucionais; era um instrumento implantado com o Golpe. Veio, então, o AI-5, em 13.12.1968, que rompe com esta ordem constitucional. Sucessivos atos-institucionais foram baixados, até que em 17.9.1969 veio a Emenda Constitucional 1 à Constituição de 196, outorgada pela Junta Militar que assumira o governo. "Ela é pior que a Constituição de 1967. Malfeita, autoritária, centralizadora, praticamente entregou todos os poderes ao Executivo. Esvaziou o Poder legislativo. Retirou-lhe prerrogativas de independência. Manteve os atos institucionais e complementares". (SILVA, José Afonso. $O$ Constitucionalismo Brasileiro - evolução institucional. São Paulo: Malheiros, 2011. pp. 79-80).

71 Utiliza-se esta expressão "antigo regime", por analogia à expressão Ancien Régime muito conhecida no Direito Administrativo, com a observação de que a nova ordem constitucional traz profundas transformações em relação àquilo que já existiu em matéria principiológica da Administração Pública no Brasil. Relativamente à passagem do Estado absoluto para o Estado liberal, Vasco Manuel Pascoal Dias Pereira da Silva, citando Parejo Alfonso e Santamaría Pastor, respectivamente, observa que "a ruptura não é total; por baixo dos princípios ideológicos e estruturais definidores do Estado constitucional existem linhas de continuidade, através das quais são vertidos e conseguem sobreviver conteúdos do antigo regime", por isso “é equívoco pensar a Revolução como um processo de ruptura e destruição da Administração absolutista, sem construir outra para o seu lugar. Certamente, que as estruturas organizatórias do Antigo regime experimentam uma mudança extraordinária na sua configuração formal, mas sem descontinuidade nem enfraquecimento". Conclui o professor português, que "continuidade não é, no entanto sinônimo de 'plágio', ou de total ausência de ruptura e de inovação no que respeita à Administração Pública do Estado liberal. Se a Revolução francesa (apesar das 'declarações de princípios' em contrário) não fez tábua-rasa da realidade político-jurídico anterior, o que é certo é que ela introduziu profundas transformações no domínio administrativo. As instituições 'herdadas' do Antigo regime vão ser entendidas e enquadradas no âmbito das novas concepções do liberalismo político, o que altera a sua natureza e modo de funcionamento. A mescla das velhas instituições com os novos princípios, assim como o surgimento de novas instituições, têm como resultado uma 'combinação original' que é a Administração Pública do Estado liberal”. (SILVA, Vasco 
1988, que introduzem profundas alterações e transformações no domínio administrativo. Estas concepções, assim, que inspiram o funcionamento das instituições terão de ser reavaliadas para estas venham a se enquadrar na nova ordem constitucional.

Cumpre observar que os princípios de Estado Democrático de Direito possuem conteúdos específicos; todavia, atuam imbricadamente, completando-se, limitando-se e condicionando-se de forma recíproca, em uma base antropológica comum.

E novamente lembramos Gomes Canotilho ${ }^{72}$, cujas considerações feitas à Constituição portuguesa de 1976, mutatis mutadis, se mostram consentâneas à nossa de 1988. Estes dois princípios estruturantes "assentam numa base antropológica comum, que na Constituição (...) se reconduz à <<tríade mágica〉>: o homem como pessoa, como cidadão e como trabalhador. Consequentemente, o indivíduo é protegido na sua identidade e integridade física e espiritual através da vinculação dos poderes públicos a formas, regras e procedimentos jurídicos (princípios do Estado de direito), é inscrito como homem livre no processo de participação e decisão democrática (princípios democrático e republicano), é-lhe garantida a liberdade perante os riscos da existência do acesso ao trabalho, à iniciativa econômica e ao direito à segurança social (princípio do Estado social)”.

\subsubsection{Ainda sobre o Estado Democrático: a complexidade do princípio democrático}

Superando a fórmula Popper, mencionada por Gomes Canotilho ${ }^{73}$, o princípio democrático se mostra complexo. Além de revelar que a democracia não se limita à forma ou técnica processual de seleção e destituição pacífica de dirigentes, ela agrega outras dimensões e relações.

Atento ao que já se expôs, superando sua dimensão representativa, o princípio ganha dimensão participativa, ou seja, “a estruturação de processo que oferecem aos cidadãos efectivas possibilidades de apreender a democracia, participar nos processo de decisão, exercer controlo crítico na divergência de opiniões, produzir inputs políticos democráticos".

Manuel Pascoal Dias Pereira da. Em Busca do Acto Administrativo Perdido. Coimbra: Coimbra, 2003. p. 39).

${ }^{72}$ CANOtIlHO, J. J. Gomes. Direito Constitucional e Teoria da Constituição. $7^{\mathrm{a}}$ edição. Coimbra: Edições Almedina, 2003. pp. 1185-1186.

${ }^{73}$ Idem, ibidem. pp. 288-291. Todas as citações neste subitem são de Gomes Canotilho, observando-se que embora ele faça menção à Constituição portuguesa, suas considerações se mostram aplicáveis à nossa Constituição de 1988. 
Além disso ganha dinamicidade na medida em que não se "compadece com uma compreensão estática da democracia. Antes é mais um processo de continuidade transpessoal, irredutível a qualquer vinculação do processo político a determinadas pessoas (...) a democracia é um processo dinâmico inerente a uma sociedade aberta e activa, oferecendo aos cidadãos a possibilidade de desenvolvimento integral e de liberdade de participação crítica no processo político em condições de igualdade económica, política e social".

Por fim, como princípio informador do Estado e da sociedade e organizador da titularidade e exercício do poder, cujos elementos básicos são os direitos fundamentais, ele promove um processo de democratização.

Em outras palavras, "A democracia é, no sentido constitucional, democratização da democracia".

\subsection{A Administração Pública na Constituição de 1988}

O Estado moderno e a Administração Pública são dois fenômenos inseparáveis a ponto de ser difícil imaginá-los de modo independente. Evidentemente que tal correspondência não é absoluta; entretanto quando a ideia de Estado muda, também deve mudar a de Administração Pública.

A história da Administração tem sido uma crônica de ensaios de adaptação a seus contextos e muito particularmente ao Estado e à Sociedade. Contudo, o problema de adaptação parece ainda ser um grande desafio a ser superado.

Observa o professor Alejandro Nieto que "de ordinário os objetivos do Estado se frustram por culpa de uma Administração insuficientemente operativa, ou, se se quiser, porque se fixam de maneira frívola certos objetivos, excessivamente ambiciosos, sem ter em conta a pobreza de meios administrativos disponíveis para alcançá-los"74.

O Estado brasileiro mudou com o advento da Constituição de 1988 e, por conseguinte, terá de mudar a Administração Pública. Esta mudança, naquilo que diz respeito ao objeto desta dissertação, se materializa na inserção do princípio de impessoalidade.

Discorrendo sobre a Administração Pública espanhola - embora a idéia se amolde à Administração Pública brasileira -, o professor Alejandro Nieto anotou que

\footnotetext{
${ }^{74}$ ALEJANDRO NIETO. El Desgobierno de lo público. Madrid: Editorial Ariel, 2008. p. 247.
} 
para entendê-la é necessário ter em vista suas três faces: a de instrumento, a de poder e a de butim.

Atuando por meio dela, o Estado tem a Administração Pública como um instrumento, "mas sem esquecer que se trata de uma organização proteica e de atividade polivalente dado que seu âmbito de atuação é elástico como consequência não apenas das variações da atividade que se considera pública, mas também porque a mesma função pode ser realizada não de maneira burocrática mas gerida em um cenário de mercado e até pelo setor privado: o que forçosamente deve alterar sua importância e desnaturalizar seu alcance”. E como centro de poder, a Administração Pública, continua o professor espanhol, "vai muito além de sua função meramente instrumental, e em tal condição opera, segundo sabemos, como um contrapeso político. Sendo assim, esta condição de poder atrai inevitavelmente a ambição de outras forças sociais, que aspiram a ocupar a Administração Pública para desfrutar de seus privilégios e fundamentalmente das rendas que obtém. Com a consequência de que se não se ajusta a defendê-la, como é atualmente o caso espanhol, termina convertendo-se em um butim de grupos corporativos e em maior medida ainda da classe política" ${ }^{, 75}$.

O Estado, como se sabe, desenvolve suas atividades por meio do governo, que atua, por sua vez, por intermédio da Administração Pública. A efetividade do Estado depende da qualidade do governo, e a efetividade deste depende da capacidade operativa da Administração Pública ${ }^{76}$.

Nos termos da nova ordem constitucional, a República Federativa do Brasil, como Estado Democrático de Direito se organiza político-administrativamente ${ }^{77} \mathrm{em}$ União, Estados, Distrito Federal e Municípios, todos autônomos, nos termos da Constituição, e estabelece que a Administração Pública ${ }^{78}$ direta e indireta de quaisquer dos poderes destes órgãos político-administrativos obedecerá, além de outras normas, aos princípios de legalidade, impessoalidade, moralidade, publicidade e eficiência.

A Constituição da República de 1988, no Título III ${ }^{79}$, Da Organização do Estado, mais precisamente no Capítulo VII, Da Administração Pública, dispõe em seu art. 37, caput, que "A administração pública direta e indireta de qualquer dos poderes da

\footnotetext{
${ }^{75}$ ALEJANDRO NIETO. El Desgobierno de lo público. Madrid: Editorial Ariel, 2008. p. 248.

${ }^{76}$ Idem, ibidem. p. 245

${ }_{77}^{77}$ Veja-se o art. 18, caput, da Constituição da República.

78 Veja-se art. 37, caput, da Constituição da República.

79 Mostra-se relevante observar que a Administração Pública está inserida na estrutura constitucional no âmbito da Organização do Estado e não, por exemplo, no Título I, que trata dos princípios fundamentais, ou ainda do Título II, que trata dos direitos e garantias fundamentais.
} 
União, dos Estados, do Distrito Federal e dos Municípios” obedecerá, além de outros princípios contidos no próprio caput e de outras regras constantes nos incisos que o seguem, ao princípio de impessoalidade.

Logo se nota que o princípio em questão é aplicável com exclusividade à Administração Pública. Por conseguinte, integra os princípios do Direito Administrativo.

Segundo Cármen Lúcia Antunes Rocha ${ }^{80}$, a Constituição da República de 1988 “inovou o tratamento do tema referente à Administração e consolidou a sua constitucionalização, estabelecendo a principiologia que domina, desde então, o seu regime jurídico.

A opção constitucional brasileira obedece, em parte, a uma tendência verificada, geralmente, qual seja, a de erigir em matéria constitucional a disciplina da Administração Pública em seus princípios, e, em outra parte, a uma necessidade de o Estado brasileiro, pouco afeito, especialmente no desempenho daquela atividade, circunscrever-se, na prática, ao Direito".

Esta afirmação da atual ministra do Supremo Tribunal Federal de que a Administração Pública brasileira era pouco afeita ao Direito se mostra em sintonia com a inserção, em sua principiologia, além dos consagrados princípios de legalidade e de moralidade, do incipiente princípio de impessoalidade.

Este novel princípio se amolda perfeitamente aos predicados que nossa República passou a adotar com o advento da Constituição de 1988, conforme anotou a professora mineira. Ou seja, "retrata uma República a se realizar segundo padrões voltados ao próximo século e que: a) não se realiza num estado que detém apenas um centro de poder, pois a sociedade passou a formar, em seu seio e fora do governo, centros de poder a se coordenarem com aquele e que buscam a participação na gestão da coisa pública, de maneira direita e permanente; b) domina-se pelo fundamento da legitimidade, que se assenta numa ética firmada e afirmada socialmente, sendo insuficiente, para esta sociedade política que hoje busca ser atendida pelo Estado Democrático de Direito, a legalidade sem o fundamento material de sua validade; c) a atividade administrativa é essencial para que os fundamentos ideológico-jurídicos sejam atendidos e os seus fins sejam realizados; d) o Estado Democrático Social não se enquadra no paradigma de uma Administração Pública abúlica, aética e afastada do público, e o Direito que preside o desempenho desta atividade deve se reportar às novas propostas e perspectivas da sociedade participativa, atuante e

${ }_{80}^{80}$ ROCHA, Cármen Lúcia Antunes. Princípios constitucionais da administração pública. Belo Horizonte: Del Rey, 1994. p. 65. 
responsável pelas suas coisas; e) não apenas as atividades administrativas a serem desenvolvidas pelo Estado contemporâneo aumentaram, traduzindo a nova realidade socioeconômica e política que se tem no mundo desde o final da Segunda Guerra Mundial, mas, principalmente, tais desempenhos se modificaram em seu conteúdo, em seus fins e em sua forma de prestação" ${ }^{, 81}$.

Em sentido semelhante, quanto ao tratamento constitucional à Administração Pública, Gustavo Binenbojm ${ }^{82}$, acrescentando que "o tratamento constitucional de aspectos da Administração Pública foi inaugurado nas Constituições espanhola e portuguesa", anota que a Constituição desce "a minúcias que exibem uma feição coorporativa muito mais nítida que qualquer preocupação garantística", mas também "trouxe alguns avanços, como a enunciação expressa de princípios setoriais do direito administrativo", dentre eles o de impessoalidade, que "a tensão entre a eficiência e legitimidade democrática é uma das questões centrais da Administração Pública na atualidade".

Nota-se, na verdade, que a nova ordem constitucional pretende mudar o modo de agir da Administração Pública, e não há dúvida de que o princípio de impessoalidade é um dos elementos relevantes desta mudança. É, de fato, antes de tudo uma decisão política, uma inversão do ponto de observação à semelhança do que se tem lido em textos de Direito Administrativo referente à revolução copernicana ${ }^{83}$.

Utilizando da realidade advinda das três faces da Administração espanhola citada Alejandro Nieto poder-se dizer que o novel princípio é mecanismo auspicioso de instrumentalização da Administração Pública para o exercício do poder - em sua dimensão administrativa - que contribuirá para a desfiguração de suas três faces.

\footnotetext{
${ }^{81}$ ROCHA, Cármen Lúcia Antunes. Princípios constitucionais da administração pública. , Belo Horizonte: Del Rey, 1994. p. 65. Anote-se que a Cármen Lúcia Antunes Rocha chega a denominar o princípio de impessoalidade e o de publicidade, como princípios-garantia (p. 66).

${ }^{82}$ Idem, ibidem, 526-527.

${ }^{83}$ Norberto Bobbio observa que "Não é verdade que uma revolução radical só possa ocorrer necessariamente de modo revolucionário. Pode ocorrer também gradativamente. Falo aqui de revolução copernicana precisamente no sentido kantiano, como inversão do ponto de observação" (BOBBIO, Norberto. A era dos direitos. Carlos Nelson Coutinho (Trad.) e apresentação de Celso Lafer. Rio de Janeiro: Elsevier, 2004. p. 74).
} 
2.5.1. A Administração Pública como um dos integrantes da relação política.

Como bem observa Norberto Bobbio ${ }^{84}$, a "relação política por excelência é a relação entre governantes e governados, entre quem tem o poder de obrigar com suas decisões os membros do grupo e os que estão submetidos a essas decisões”. Esta relação, contudo, pode ser vista tanto sob o ângulo dos governantes, quanto sob o ângulo dos governados.

O professor italiano informa que no curso do pensamento político predominou durante séculos o ângulo dos governantes; “o objeto da política foi sempre o governo, o bom governo ou o mau governo, ou como se conquista o poder e como ele é exercido, quais são as funções dos magistrados, quais são os poderes atribuídos ao governo e como se distinguem e interagem entre si, como se fazem as leis para que sejam respeitadas, como se declaram as guerras e se pactua a paz, como se nomeiam os ministros e os embaixadores. Basta pensar nas grandes metáforas mediante as quais, ao longo dos séculos, buscou-se tornar compreensível a natureza da arte da política: o pastor, o timoneiro, o condutor, o tecelão, o médico. Todas se referem a atividades típicas do governante: a função de guia, da qual deve dispor para poder conduzir à sua própria meta os indivíduos que lhe são confiados, tem necessidade de meios de comando; ou a organização de um universo fracionado necessita de uma mão firme para ser estável ou sólida; os cuidados devem por vezes ser enérgicos para terem eficácia sobre um corpo doente".

Com o advento da Constituição 1988, esta relação mudou o enfoque, seu ponto de observação é outro.

A nova ordem constitucional reposicionou o ser humano nesta relação política, colocando-o no centro de suas atenções e deu início àquilo que se poderia chamar de revolução antropológica agora sobre o enfoque do administrado ${ }^{85}$.

Esta revolução, contudo, parece, segundo alguns autores ${ }^{86}$, conflitar com outra realidade relativa à gênese do brasileiro. E isso tudo a ponto de se cogitar que esta

\footnotetext{
${ }^{84}$ BOBBIO, Norberto. A era dos direitos. Carlos Nelson Coutinho (Trad.) e apresentação de Celso Lafer. Rio de Janeiro: Elsevier, 2004. pp. 74-75.

85 O termo administrado é utilizado como aglutinador de toda a sociedade que inevitavelmente mantém relação com a Administração Pública. Longe de conotar a ideia de súditos ou de expressões afins, visa a sintetizar um dos integrantes (em sua forma individual ou coletiva) da relação político-jurídico estabelecida com a Administração Pública.

${ }^{86}$ Irene Patrícia Nohara observa que "Concordamos, portanto, com Jasson Hibner Amaral quando diz que a falta de efetividade do princípio de impessoalidade deve-se muito mais a um problema cultural do que propriamente técnico. É claro que o reconhecimento e a punição das situações em que há violação da
} 
realidade tupiniquim pudesse ser a causa da "falta de efetividade" do princípio de impessoalidade. Como se certa natureza de agir própria do brasileiro, dependente exclusivamente de uma vontade íntima, pudesse dar ou não efetividade ao princípio.

A despeito de entendimentos contrários, não parece que a questão de efetividade do princípio de impessoalidade seja de natureza cultural (antropológica). A questão, na verdade, parece ter dupla natureza: de compreensão da (nova) realidade jurídica e de técnica jurídica.

Embora não pareça possível desvincular as raízes remotas do princípio de impessoalidade a elementos de antropologia (relação política entre governantes e governados, experiência monárquica no Brasil, certo descompromisso social com a coisa pública etc.), pode-se dizer que sua "falta de efetividade" parece estar mais relacionada com a equivocada compreensão que se tem tido desta norma constitucional e com a estrutura jurídico-administrativa adotada desde então.

\subsection{A novidade constitucional do princípio de impessoalidade ${ }^{87}$}

"Não há nada mais poderoso do que uma ideia cujo tempo chegou" 88.

impessoalidade, que frequentemente deságuam no abuso de poder e na improbidade, são meios eficientes para coibir tais ocorrências; contudo, a carência de efetividade do princípio de impessoalidade, principalmente por parte dos agentes políticos, deita raízes profundas na colonização brasileira, haja vista a forma com que foi realizada, e mesmo com a independência, e posteriormente com a República, não se pôs fim à manifestação do poder privado na esfera pública (...) Cabe mencionar a conhecida frase de Pierre Escoube, qual seja, 'a Administração Pública vale exatamente o quanto valem os homens que a compõem', porque a disseminação da efetiva impessoalidade, na qual os agentes de fato incorporem a dimensão da legalidade e do interesse público em suas práticas principia, naturalmente, com a pedagógica punição, mas somente será consolidada a partir da disseminação de uma cultura ética (pública) nas administrações brasileiras". (NOHARA, Irene Patrícia. Direito Administrativo. São Paulo: Atlas, 2011. p. 72-73). Na mesma linha de raciocínio, as considerações de Márcio Pestana: "Como se percebe, o princípio da impessoalidade, sob esta ótica parte da exata compreensão da natureza humana, sobretudo de suas características de vaidade e ambição, vedando a pessoalidade na e da Administração Pública, de certa maneira entorpecendo e estabelecendo limites rigorosos a determinados valores que, inegavelmente, encontram-se presentes nos responsáveis pela Administração Pública - como, aliás, onde houver ser humano -, e que, se não prontamente identificados e eficazmente contidos, podem irromper-se em afronta à ordem concreta almejada pelo Direito". (PESTANA, Márcio. Direito Administrativo Brasileiro. $3^{a}$ ed. Rio de Janeiro: Elsevier, 2012, p. 207) Registre-se, ainda, as considerações de Cristina Andrade Melo: "Somado ao que foi dito, tem-se que a cordialidade, tida por Sérgio Buarque de Holanda como característica do brasileiro, também como fator que dificulta a atuação impessoal dos agentes públicos. A cordialidade do brasileiro, entendida como tudo aquilo que vem do coração, para o bem ou para o mal e destituído de razão, é um grande entrave à afirmação do princípio de impessoalidade, pois dificulta a separação entre os domínios privado e público por parte dos detentores do poder e afasta a necessária isenção e neutralidade no trato da cosia pública". (MELO, Cristina Andrade. O princípio da impessoalidade - Audiência pública como contributo à imparcialidade na atuação estatal. In BATISTA JÚNIOR, Onofre Alves; CASTRO, Sérgio Pessoa de Paula. (coords.). Tendências e perspectivas do Direito Administração: uma visão da escola mineira. Belo Horizonte: Fórum, 2012. Belo Horizonte: Fórum, 2012p. 290).

87 Observe-se que o legislador constitucional registrou a expressão princípio de impessoalidade, e não princípio da impessoalidade. A diferença das expressões será analisada mais adiante. Deve-se registrar, contudo, desde já, que este trabalho adota a primeira expressão. 
Lívia Maria Armentano Koenigstein Zago ${ }^{89}$, na introdução de sua monografia intitulada $O$ princípio da impessoalidade, afirma que "o princípio da impessoalidade constitui-se em novidade no Direito pátrio, foi dado à luz com a Constituição de 1988”.

Em O princípio da impessoalidade da Administração pública: para uma Administração Imparcial, Ana Paula Oliveira Ávila inicia a primeira parte de sua monografia dizendo que o "princípio da impessoalidade aparece pela primeira vez com esta denominação na Constituição Federal de 1988"90.

Ao iniciar sua exposição sobre o princípio, José dos Santos Carvalho Filho registra que "esse princípio no texto constitucional, no que toca ao termo impessoalidade, constitui uma surpresa para os estudiosos, que não o empregavam em seus trabalhos". E logo conclui, referindo-se ao dicionário Caldas Aulete, que "Impessoal é 'o que não pertence a uma pessoa em especial', ou seja, aquilo que não pode ser voltado especialmente a determinadas pessoas" ${ }^{91}$.

Este, contudo, não é o entendimento de Cármen Lúcia Antunes Rocha ${ }^{92}$ que afirma que o "princípio da impessoalidade estava posto explicitamente na Lei 10 de outubro de 1828 , em cujo art. 38 , se dispunha:

'Nenhum vereador poderá votar em negócio de seu particular interesse, nem

dos seus ascendentes ou descendentes, ou Cunhados, enquanto durar o cunhadio. Igualmente não votarão aqueles que jurarem suspeição"”.

A despeito de se vislumbrar mesmo uma "ideia poderosa"93, a doutrina não chega a um consenso nem mesmo sobre a inovação constitucional.

${ }^{88}$ Esta frase do escritor e dramaturgo francês Victor Hugo foi citada por Diogo Freitas do Amaral, (AMARAL, Diogo Freitas do. História do Pensamento Político Ocidental. Coimbra: Almedina, 2011. p. 704).

89 ZAGO, Lívia Maria Armentano Koenigstein. O princípio da impessoalidade. Rio de Janeiro: Renovar, 2001. p. 2.

90 ÁVILA, Ana Paula Oliveira. O princípio da impessoalidade da administração pública: para uma administração imparcial. Rio de Janeiro: Renovar, 2004. p. 17.

${ }^{91}$ CARVALHO FILHO, José dos Santos Manual de Direito Administrativo. $25^{\mathrm{a}}$ ed. ampliada e atualizada até 03.01.2012. Rio de Janeiro: Lumen Juris, 2012. p. 20.

92 ROCHA, Cármen Lúcia Antunes. Princípios constitucionais da administração pública. , Belo Horizonte: Del Rey, 1994. p. 162.

93 Este trabalho admite que esta "ideia poderosa" é verdadeiramente uma inovação constitucional. Não apenas como expressão (como signo), mas também como significado. Em relação a este princípio, aliás, sua discussão parece estar em segundo plano, sofrendo as consequências daquilo que se denominou de modernidade líquida (a expressão é do sociólogo polonês BAUMAN, Zygmunt. Vida Líquida. Carlos Alberto Medeiros (Trad.). $2^{\mathrm{a}}$ ed. rev. Rio de Janeiro: Zahar, 2009). De algum modo a doutrina não tem se preocupado - mantém-se um dissenso insustentável - sobre este tema relevante de natureza administrativa ético-jurídico. Em outras palavras, a preocupação da doutrina parece mudar num tempo mais curto do que aquele necessário para a consolidação, em hábitos e rotinas, das formas de atuação do agente administrativo. 
Sustentando que este o princípio aparece "pela primeira vez, com essa denominação, no art. 37 da Constituição de 1988”, Maria Sylvia Zanella Di Pietro ${ }^{94}$ afirma que ele "não tem sido objeto de análise pela doutrina brasileira" e "está dando margem a diferentes interpretações".

Esta realidade de alguma forma é confirmada por Odete Medauar que observa, após mencionar interpretação de José Afonso da Silva, Hely Lopes Meirelles e Celso Antônio Bandeira de Mello, que os aspectos apontados por estes doutrinadores "representam ângulos diversos" deste princípio, acrescentando que "os princípios da impessoalidade, moralidade e publicidade apresentam-se intrincados de maneira profunda, havendo mesmo, instrumentalização recíproca” e que "embora nem sempre seja possível afastar as implicações recíprocas desses princípios, o estudo separado atende a requisitos didáticos" 95 .

Em relação à lição da professora Odete Medauar mostra-se pertinente observar dois aspectos. O primeiro é que, a despeito desta intrincada relação do princípio de impessoalidade com outros princípios, e também por ela ${ }^{96}$, sua identificação, distinguindo-o dos demais, não atende apenas a pretensões didáticas, mas possui relevância jurídica prática. O segundo é que não se trata apenas de focar o princípio de ângulos diversos, mas de, com isso, ora desconsiderá-lo ${ }^{97}$, ora relacioná-lo a outro princípio distinto dele ${ }^{98}$, trazendo ambiguidade ${ }^{99}$ a este relevante princípio da Administração Pública da

${ }^{94}$ DI PIETRO, Maria Sylvia Zanella. Direito Administrativo. $25^{\mathrm{a}}$ ed. São Paulo: Atlas, 2012. p. 68.

${ }^{95}$ MEDAUAR, Odete. Direito Administrativo Moderno. $15^{\text {a }}$ ed. revista, atual.e ampl. São Paulo: Revista dos Tribunais, 2011. p. 132.

96 A expressão intricado, é pertinente ressaltar, significa "obscuro, confuso", "enredado, emaranhado", “custoso de perceber”, conforme NOVO AURÉLIO - O Dicionário da Língua Portuguesa Século XXI. $3^{\text {a ed. }}$ Rio de Janeiro: Nova Fronteira, 1999.

${ }^{97} \mathrm{O}$ professor Celso Antônio Bandeira de Mello ao afirmar que "O princípio em causa não é senão o próprio princípio da igualdade ou isonomia” (BANDEIRA DE MELLO, Celso Antônio. Curso de Direito Administrativo. $21^{\mathrm{a}}$ ed. revista e atualizada até a Emenda Constitucional 52, de 8.3006. São Paulo: Malheiros, 2006) não lhe confere o conteúdo que lhe é peculiar e distintivo, a ponto de se poder falar que este doutrinador não o considera como um princípio. Aliás, é o que se poder dizer do professor Hely Lopes Meirelles quando registrou que "O princípio da impessoalidade, referido na Constituição de 1988 (art. 37, caput), nada mais é que o clássico princípio da finalidade, o qual impõe ao administrador público que só pratique o ato para o seu fim legal. E o fim legal é unicamente aquele que a norma de Direito indica expressa ou virtualmente como objetivo do ato, de forma impessoal" (MEIRELLES, Hely Lopes. Direito Administrativo Brasileiro. $21^{\mathrm{a}}$ ed. Atualizada por Eurico de Andrade Azevedo, Délcio Balestero Aleixo e José Emmanuel Burle Filho. São Paulo: Malheiros, 1996).

98 Aqui se incluem os autores que não afirmam a identidade do princípio com outros princípios, mas que de alguma forma dão-lhe conotação aproximada a outros princípios.

99 Sobre ambiguidade, distinguindo-a de imprecisão, o professor Eros Roberto Grau anota: "Assim, ambiguidade e imprecisão são marcas características da linguagem jurídica. Manifesta-se a primeira em virtude de as mesmas palavras em diversos contextos designarem distintos objetos, fatos ou propriedades (...) Quanto à imprecisão, decorre de fluidez de certas palavras, cujo limite de aplicação é impreciso. Buscando exemplos na linguagem comum, ali teremos os vocábulos 'jovem', 'alto', 'calvo”" (GRAU, Eros Roberto. 
República Federativa do Brasil e, por conseguinte, contribuindo como "elemento facilitador e legitimador da superficialidade e do voluntarismo", criticados pelo professor Carlos Ari Sundfeld ${ }^{100}$.

A propósito, superficialidade e voluntarismo parecem ser expressões opostas àquelas que se extrai do princípio de impessoalidade.

Nesse contexto, considerando a normatividade principiológica da Constituição da República parece haver necessidade de maior preocupação da doutrina sobre o aprofundamento do tema. Não se mostra razoável admitir que ao tratar expressamente do princípio de impessoalidade ${ }^{101}$ a Constituição tenha desejado dizer ou dito princípio de igualdade ou de finalidade etc.

Compreender o princípio de impessoalidade como sendo “imparcialidade", "neutralidade", “objetividade", "imputação", conforme se infere da doutrina examinada, parece ser tão equivocado quanto repetir a frase "administrar é aplicar a lei de ofício" $" 102$ com o sentido de aplicar a lei automaticamente ${ }^{103}$ ou ainda

Porque tenho medo dos juízes (a interpretação/aplicação do direito e dos princípios). $6^{\text {a }}$ edição refundida do ensaio e discurso sobre a interpretação/aplicação do direito. São Paulo: Malheiros, 2013. p. 143-144).

${ }^{100}$ SUNDELD, Carlos Ari. Direito Administrativo para os céticos. São Paulo: Malheiros, 2012. p.80. Anote-se que o autor argumenta, mais enfaticamente, que "o uso retórico de princípios muito vagos vem sendo um elemento facilitador e legitimador da superficialidade e do voluntarismo. E por que facilitador e legitimador? Porque belos princípios ninguém tem coragem de refutar, e muita gente se sente autorizada a tirar conclusões bem concretas apenas recitando fórmulas meio poéticas (aliás, de preferência muitas delas como se enfileirar princípios, todos muitos vagos, aumentasse a força da conclusão). A verdade é que motivações e discussões que ficam nesse plano de generalidades são insuficientes para conclusões concretas. A razão é óbvia: nesse plano, quase todo mundo tem alguma razão no que diz" (p. 80). Sobre "todo mundo", a propósito, pode-se destacar não apenas a própria Administração Pública, mas também os órgãos de controle.

${ }^{101}$ A despeito de controvérsia doutrinária, este trabalho parte da premissa de que o princípio de impessoalidade tem conteúdo distinto dos demais princípios da Administração Pública. A propósito, friseque a Constituição do Estado de São Paulo (em seu art. 111) também faz menção explícita a este princípio e, implicitamente, o distingue, por exemplo, dos princípios de legalidade, moralidade, publicidade, finalidade, motivação, interesse público e de eficiência, na medida em que os explicita também. Assim, dispôs o legislador estadual: "A administração pública direta, indireta ou fundacional, de qualquer dos Poderes do Estado, obedecerá aos princípios de legalidade, impessoalidade, moralidade, publicidade, razoabilidade, finalidade, motivação, interesse público e eficiência". A título de registro, mostra-se sintomático que a Lei n. 9.784, de 29.1.1999, que regula o processo administrativo no âmbito da Administração Pública Federal não faça menção ao princípio de impessoalidade. Longe de se sustentar o mito do grande legislador, citado por Norberto Bobbio (BOBBIO, Norberto. O futuro da democracia. Marco Aurélio Nogueira (Trad.). São Paulo: Paz e Terra, 2000. p. 179), referindo-se ao Contrato Social de Jean-Jacques Rousseau, este incipiente princípio além de ter significado próprio, parece reafirmar não o "governo das leis", mas o "governo das leis" em ambiente democrático.

102 Anote-se que a ideia vem da lição de Miguel Seabra Fagundes, In verbis: "2. O Estado, uma vez constituído, realiza os seus fins por meio de três funções em que se reparte a sua atividade: legislação, administração e jurisdição. A função legislativa liga-se aos fenômenos de formação do Direito, enquanto as outras duas, administrativa e jurisdicional, se prendem à fase de sua realização. Legislar (editar o direito positivo), administrar (aplicar a lei de ofício) e julgar (aplicar a lei contenciosamente) são três fases da atividade estatal, que se completam e que a esgotam em extensão. O exercício dessas funções é distribuído pelos órgãos denominados Poder Legislativo, Poder Executivo e Poder Judiciário". (FAGUNDES, Miguel 
conceber a ideia de uma supremacia do privado sobre o público ou deste sobre aquele abstrata e aprioristicamente.

Embora não se mostre crível que isso tenha se dado de modo consciente, parece que a compreensão reproduzida pela repetição descuidada daquela frase - frise-se encontradiça nos livros de Direito Administrativo ${ }^{104}$ - pressupunha a ideia de que a atuação do administrador público era a de um aplicar a lei de forma mecânica, automática, sem qualquer dificuldade; ou ainda de aplicar a lei de modo indiferente aos fins da sociedade ou às considerações feitas pelo cidadão; a de um agir descompromissado e pronto; ou ainda de um ato decorrente de indiscutível perfeição; ou ainda de um ato baseado em vontade inquestionavelmente adequada.

Isso, contudo, parecer ter gerado outra noção, hoje, incompatível com a nova ordem constitucional. Ou seja, a de que o agente público, sendo servo da lei (inquestionavelmente escravo da lei), não cometeria equívoco (porque onipotente, porque sábio), não estaria sujeito a controle; não necessitaria, enfim, fundamentar suas decisões; e mais, não estaria obrigado a ouvir e considerar em sua decisão os argumentos e pretensões formuladas pelo cidadão ou terceiros. Em outras palavras, por todas, não teria o dever jurídico de expor os fatos e fundamentos que justificaram sua ação.

Seabra. Controle dos Atos Administrativos pelo Poder Judiciário. $8^{\text {a }}$ edição atualizada até 2010, por Gustavo Binenbojm. Rio de Janeiro: Forense, 2010. p. 3).

${ }^{103}$ Antonio Carlos Cintra do Amaral argumenta que "Na doutrina brasileira, encontramos com frequência a citação da clássica definição de Miguel Seabra Fagundes (...) de que administrar é 'aplicar a lei de ofício'. Com isso quer-se sustentar que, para Seabra Fagundes, ao administrador cabia cumprir automaticamente a lei, e nada mais. Que a atividade administrativa está submetida à lei, ninguém discute. Mas que o administrador seja 'escravo da lei', ou 'a boca que pronuncia as palavras da lei', quase ninguém sustenta. Quando o saudoso jurista brasileiro formulou essa definição teve por objetivo distinguir a função administrativa da função jurisdicional. $\mathrm{O}$ administrador age 'de ofício'. O juiz, por provocação das partes. Isso é o que me parece resultar da leitura de todo o trecho em que a definição está contida: 'A função legislativa liga-se aos fenômenos de formação do Direito, enquanto as outras duas, administrativa e jurisdicional, se prendem à fase de sua realização. Legislar (editar o direito positivo), administrar (aplicar a lei de ofício) e julgar (aplicar a lei contenciosamente) são três fases da atividade estatal, que se completam e que a esgotam em extensão"'. (AMARAL, Antonio Carlos Cintra do. Teoria do Ato Administrativo - prefácio de Celso Antônio Bandeira de Mello. Belo Horizonte: Fórum, 2008. p. 26-27). Este também é o entendimento de J. Cretella Júnior: “devemos ressaltar, nesta altura, outra vez, que 'administrar é, na quase totalidade dos casos, aplicar a lei de ofício', ou seja, sem provocação, normalmente embora haja casos do interessado pelo emprego dos recursos administrativos, próprios e impróprios, devendo-se notar, entretanto, que não se trata, como no caso da jurisdição, da aplicação contenciosa da lei pelo Magistrado" (CRETELLA JÚNIOR, J. Elementos de Direito Constitucional. $4^{\text {a }}$ ed. revista, atualizada e ampliada. São Paulo: Editora Revista dos Tribunais, 2000. p. 115-116).

104 FAGUNDES, Miguel Seabra. Controle dos Atos Administrativos pelo Poder Judiciário. $8^{\mathrm{a}}$ edição atualizada até 2010, por Gustavo Binenbojm. Rio de Janeiro: Forense, 2010. p. 3. BANDEIRA DE MELLO, Celso Antônio. Curso de Direito Administrativo. $21^{\mathrm{a}}$ ed. revista e atualizada até a Emenda Constitucional 52, de 8.3006. São Paulo: Malheiros, 2006. p. 73. CRETELLA JÚNIOR, J. Elementos de Direito Constitucional. $4^{\mathrm{a}}$ ed. revista, atualizada e ampliada. São Paulo: Editora Revista dos Tribunais, 2000. p. 115. 


\section{III - CONSIDERAÇÕES SOBRE O DIREITO ADMINISTRATIVO}

Estas considerações, embora não exaustivas, tem a finalidade de trazer informações que, de algum modo, contribuirão para a compreensão dos fenômenos administrativos e, por conseguinte, para se descobrir o significado de institutos, categorias e conceitos do Direito Administrativo.

Naquilo que diz respeito a este estudo, atento à nova ordem constitucional de 1988, estas informações são levadas em conta - e não podem ser desconsideradas - para a investigação do conceito jurídico do princípio de impessoalidade.

\section{1. Seus dados históricos}

O Direito Administrativo nasceu de duas ideias fundamentais: a de Separação de Poderes e a de Legalidade ${ }^{105}$. Em singela síntese do essencial, aquela viabilizou sua existência autonômica e esta lhe impôs uma especificidade, delimitando seu funcionamento.

Maria Sylvia Zanella Di Pietro ${ }^{106}$ observa que o Direito Administrativo brasileiro recebeu influência estrangeira, em sua origem, em especial, do direito francês e italiano. E que "Do direito francês, o direito administrativo brasileiro acolheu a ideia de ato administrativo, com o atributo da autoexecutoriedade, as sucessivas teorias sobre responsabilidade civil do Estado, o conceito de serviço público, as prerrogativas da Administração Pública, a teoria dos contratos administrativos, o princípio da legalidade”.

Em relação à legalidade, afirma Maria Sylvia Zanella Di Pietro ${ }^{107}$ que "é curioso que, embora o direito francês considerasse o princípio da legalidade como uma das bases do direito administrativo, na prática, afastou-se desse postulado, na medida em que a jurisprudência adotada pela jurisdição administrativa transformou-se, aos poucos, na principal fonte do direito administrativo. No direito francês, falar em princípio da legalidade significa falar na força obrigatória das decisões do Conselho de Estado, órgão de cúpula da jurisdição administrativa. Em decorrência da adoção do princípio da

\footnotetext{
${ }^{105}$ DI PIETRO, Maria Sylvia Zanella. Direito Administrativo. $25^{\mathrm{a}}$ ed. São Paulo: Atlas, 2012. p. 2. RIVERO, Jean. Direito Administrativo. Doutor Rogério Ehrhardt Soares (Trad.). Coimbra: Livraria Almedina, 1981. p. 19-20. CASSAGNE, Juan Carlos. Curso de Derecho Administrativo. $10^{\mathrm{a}}$ edición actualizada y ampliada. Buenos Aires: La Ley, 2011. p. 66-70. T. 1 (DI PIETRO, Maria Sylvia Zanella . Direito Administrativo. 25 ed. São Paulo: Atlas, 2012. p. 24).

${ }^{106}$ DI PIETRO, Maria Sylvia Zanella. Direito Administrativo. $25^{\mathrm{a}}$ ed. São Paulo: Atlas, 2012. p. 22 e 23-24.

${ }^{107}$ Idem, ibidem. p. 24-25.
} 
legalidade, o direito administrativo brasileiro, à semelhança de outros direitos, como o espanhol, o português, o dos países sul-americanos, colocou no direito positivo aquilo que no direito francês constituíam teorias e princípios de elaboração jurisprudencial. Aquilo que na França é alterado pela jurisdição administrativa no Brasil depende de alteração legislativa. E com uma agravante: as bases do direito administrativo no Brasil estão na Constituição: as intervenções do Estado na propriedade privada, o regime estatutário dos servidor público, os princípios da Administração Pública, a regra sobre responsabilidade civil do Estado, o princípio da licitação, as normas sobre orçamento e contabilidade pública, as competências normativas, a proteção do patrimônio público, os direitos e garantias do cidadão perante a Administração Pública, o controle interno, o judicial e o legislativo.

A consequência é que a evolução do direito administrativo depende, em grande parte, de reformas constitucionais, o que conduz a dois caminhos: (a) um, lícito, que é a reforma pelos instrumentos que a própria Constituição prevê; (b) outro que é feito ao arrepio da Constituição, que vai sendo atropelada pelas leis ordinárias, por atos normativos da Administração Pública e, às vezes, sem qualquer previsão normativa; a Administração Pública, com muita frequência, coloca-se na frente do legislador. Daí o desprestígio da Constituição e do princípio da legalidade.

Este é talvez o maior paradoxo: afastamo-nos do direito francês e do sistema da commom law, quando colocamos a lei como principal fonte do direito. Mas, na prática, colocamos uma distância grande entre o que está na lei e o que se aplica na prática, pelo afã de copiar modelos estrangeiros nem sempre adaptáveis ao direito positivo brasileiro, em especial à Constituição".

Nota-se, nesse contexto, que além de se poder afirmar que nosso direito recebe influências do direito estrangeiro, também é possível dizer que temos uma realidade jurídica própria (como todos os outros países possuem a sua), peculiar, não encontrável, por vezes, em nenhum outro lugar. Relativamente a este segundo aspecto, pode-se encontrar tanto situações dissonantes entre a lei e a realidade, quanto a da existência de institutos jurídicos próprios.

O registro de que o Direito Administrativo recebeu influência do direito francês ${ }^{108}$ faz levantar a hipótese de que esta influência pode ter sido uma das causas

108 "o direito administrativo que hoje conhecemos é produto da Revolução Francesa" (SOUSA, Marcelo Rebelo de; MATOS, André Salgado de. Direito Administrativo Geral - Introdução e princípios fundamentais. $3^{\mathrm{a}}$ ed. Portugal: D. Quixote, 2010. p. 59. T. 1). "O Direito Administrativo surgiu, 
empíricas remotas para a concepção do princípio de impessoalidade na Constituição de 1988.

E isso se nota não apenas da gênese da disciplina ${ }^{109}$, mas também das informações trazidas por Chaïm Perelman, em sua Lógica jurídica, quando discorre sobre a motivação das decisões judiciais no direito francês, que incluem as do Conselho de Estado francês.

Diz este professor que "Embora a motivação tenha aparecido no direito francês no século XIII, limitava-se o mais das vezes a indicar a prova dos fatos e, eventualmente, a regra de direito aplicável. Mas a motivação desaparece no século XIV. Le style de la chambre des enquêtes, redigido em cerca de 1336, aconselha muito claramente o relator a 'ter grande cuidado, na conclusão da sentença, de não mencionar nenhuma 'causa'. Esta situação se prolongará durante o Antigo Regime. Além disso, era proibido publicar as decisões de justiça sem a autorização dos Parlamentos. Montesquieu insistiu sobre a importância que há em conhecer a jurisprudência, mas sem se inquietar com a

precisamente, quando os juristas e os homens de governo notaram que os direitos dos administrados não derivavam apenas das leis que, na maior parte das vezes, não prescreviam soluções para regular as controvérsias com a Administração Pública. É conhecido o papel e a gravitação que teve na elaboração de nossa disciplina o Conselho de Estado da França, cuja jurisprudência abriu um amplo caminho para arbitrar respostas justas, fundadas na realidade social, aos principais problemas que suscitava e suscita a atuação administrativa. Ao se admitir que o Estado devia reger-se por princípios diferentes aos próprios do Direito Privado, se deu um passo essencial para a formação de um direito autônomo para reger o agir da Administração no campo do Direito Público, sem prejuízo de possibilidade de recorrer à analogia. Essa jurisprudência do Conselho de Estado francês, ao aceitar a existência de regras jurídicas que não emanam da legislação positiva, permite concluir que as normas não escritas transcendiam os imperativos do poder, por sua relação direta com a pessoa humana e a natureza das coisas" (CASSAGNE, Juan Carlos. Curso de Derecho Administrativo. $10^{\mathrm{a}}$ edición actualizada y ampliada. Buenos Aires: La Ley, 2011. p. 100-101. T. 1. - tradução nossa). Maria Sylvia Zanella Di Pietro, por sua vez, afirma que o "Direito Administrativo, como ramo autônomo, nasceu em fins do século XVIII e início do século XIX, o que não significa que inexistissem anteriormente normas administrativas, pois onde quer que exista o estado existem órgãos encarregados do exercício de funções administrativas. O que ocorre é que tais normas se enquadravam no jus civile, da mesma forma que nele se inseriam as demais, hoje pertencentes a outros ramos do direito (...) Alguns vão ao ponto de afirmar que o Direito Administrativo é produto exclusivo da situação gerada pela Revolução Francesa, só existindo nos países que adotaram os princípios por ela defendidos (...) Não se afigura verdadeira a tese de que o Direito Administrativo só exista nos sistemas europeus formados com base nos princípios revolucionários do século XVIII. O que é verdadeiro é o fato de que nem todos os países tiveram a mesma história nem estruturaram pela mesma forma o seu poder; em consequência, o Direito Administrativo teve origem diversa e desenvolvimento menor em alguns sistemas, como o anglo-americano. Mesmo dentro dos 'direitos' filiados ao referido sistema europeu existem diferenças que vale a pena assinalar, uma vez que, quanto menos desenvolvido o Direito Administrativo, maior é a aplicação do direito privado nas relações jurídicas de que participa o Estado" (DI PIETRO, Maria Sylvia Zanella. Direito Administrativo. 25 ed. São Paulo: Atlas, 2012. p. 1-3).

109 "O entendimento liberal da separação de poderes marcou a origem do próprio direito administrativo: a criação de "tribunais administrativos" não foi acompanhada pela criação legislativa imediata de um novo ramo de direito, tendo a progressiva introdução de especialidades de regime da função administrativa em relação aos decorrentes do direito comum, considerados como excessivamente igualitários, sido primeiramente obra da actividade daqueles mesmos tribunais e só posteriormente objecto de acolhimento legislativo" (SOUSA, Marcelo Rebelo de; MATOS, André Salgado de. Direito Administrativo Geral Introdução e princípios fundamentais. $3^{\mathrm{a}}$ ed. Portugal: D. Quixote, 2010. p. 107. T. 1).. 
ausência da motivação. 'Em 1771, Jousse, conselheiro do presidial (tribunal) de Orléans, depois de lembrar que os juízes têm certamente o direito de motivar suas sentenças, acrescenta que é preferível não se valer de tal direito 'a fimm de não dar motivo a chicanas por parte daquele que tiver perdido a causa'.

Foi necessário como sabemos, esperar a lei de 16-24 de agosto de 1790 para expor claramente o problema da motivação, tanto no cível quanto no penal. O artigo 15 do título $\mathrm{V}$ dispõe que, em cada sentença, 'o resultado dos fatos reconhecidos ou constatados pela instrução e os motivos que houveram determinado o juiz serão expressos'. Mas, para alguns, a exigência da motivação identificava-se com a indicação do 'texto de lei que havia determinado os juízes'. Quando, pelo decreto de 10 de dezembro de 1790, foi criado o Tribunal de Cassação, 'seu artigo 17 exigia apenas que o dispositivo contivesse $o$ texto da lei ou das leis nas quais a decisão se apoiará,, mas não havia , de forma alguma, a obrigação de motivar as sentenças. Esta obrigação foi instituída, por um decreto do 4 germinal do ano II, apenas para as sentenças de indeferimento. Logo todos os arestos deverão ser motivados. 'Viu-se então que a necessidade de motivação deveria ser geral e indivisível, entendendo-se com isso que deveria aplicar-se a todas as jurisdições, à mais alta inclusive, sendo melhor dizer sobretudo à mais alta, para permitir que esta a impusesse às demais. Somente a existência da Cassação dá todo o sentido e todo o alcance à motivação no direito moderno. Ela faz de todo o julgamento um acena com vários personagens, na qual o juiz não apenas responde ao pleiteante, mas pensa também nas críticas que poderão ser formuladas em um recurso.

Foi um aresto do Conselho de Estado, de 28 de julho de 1834 (S. 34.2.628), que considerou que a motivação era exigida não apenas por um texto da lei, mas porque sua ausência infringe as formas substanciais de qualquer decisão em matéria contenciosa. Trata-se de um desses princípios gerais do direito que, ao contrário de certas concepções do direito natural, resulta da prática e dos progressos do direito entre os povos civilizados"110.

Em outras palavras, originariamente o Direito Administrativo de algum modo não estava preocupado em dar plena satisfação de seus atos àqueles que estavam submetidos a ele, ou seja, à sociedade.

110 PERELMAN, Chaïm.Lógica jurídica: nova retórica.Vergínia K. Pupi (Trad.). Maria Ermantina de Almeida Prado Galvão (rev. trad.). Revista Técnica Gildo Sá Leitão Rios. $2^{a}$ ed. São Paulo: Martins Fontes, 2004. p. 211, observando-se que o autor faz menção a T. Sauvel ('Histoire du jugement motivé', Ver. Dr. Publ., 1955, PP 5-6). 


\section{2. Sua relação com a Constituição}

A Constituição nem sempre teve muito relevância para o Direito Administrativo no Estado Liberal.

Marcelo Rebelo de Sousa e André Salgado de Matos afirmam que "para além da inexistência de uma verdadeira parametricidade dos textos constitucionais, estes disciplinavam essencialmente apenas o estatuto e os mecanismos de inter-relação dos órgãos políticos do Estado, bem como alguns direitos fundamentais dos indivíduos, cuja oponibilidade ao Estado era ainda limitada pela visão das pessoas como substancialmente subordinadas ao poder"111.

Atualmente, no Brasil, a primeira fonte do Direito Administrativo é a Constituição da República ${ }^{112}$. Nela está o núcleo deste ramo deste direito, embora poucas disposições constitucionais deixam de ter relação com o Direito Administrativo.

Apesar de a Constituição não estabelecer quem tenha competência para legislar sobre Direito Administrativo ${ }^{113}$ (conforme dispõe, por exemplo, o art. 22, acerca da competência para legislar sobre direito civil, comercial e outros), ela dispõe sobre vários temas de Direito Administrativo, como por exemplo, desapropriação (CR, art. 22, inc. II), requisições civis e militares, em caso de iminente perigo e em tempo de guerra $(\mathrm{CR}$, art. 22, inc. III) e normas de licitação e contratação (CR, art. 22, inc. XXVII).

Tema central do Direito Administrativo, a Administração Pública é objeto de detalhada regulamentação constitucional, tendo o legislador não apenas estabelecido seus princípios, mas também firmado várias regras para sua atuação (CR, do art. 37 ao art. 43).

\footnotetext{
111 SOUSA ,Marcelo Rebelo de; MATOS, André Salgado de. Direito Administrativo Geral - Introdução e princípios fundamentais. $3^{\mathrm{a}}$ ed. Portugal: D. Quixote, 2010. p. 64. Tomo 1.

112 "A Constituição de 1988 constitui um inequívoco marco para o direito administrativo brasileiro, Na verdade, não parece excessivo, nem há mais qualquer novidade em se reconhecer que o direito administrativo que exsurgiu da Constituição de 1988 é um direito administrativo muito diferente daquele que se preconizava até então. As mudanças mais importantes se operaram no campo dos pressupostos teóricos" (BAPTISTA, Patrícia. Invalidação dos atos administrativos e devido processo legal: Limites Constitucionais á autotutela administrativa: o dever de observância do contraditório e da ampla defesa antes da anulação de um ato administrativo ilegal e seus parâmetros. IN BARROSO, Luís Roberto (org.). A reconstrução democrática do direito público no Brasil, Rio de Janeiro: Renovar, 2007. p. 547).

${ }^{113}$ Embora não seja este o enfoque do estudo, cremos que a processualidade administrativa se inclui na competência privativa da União para legislar sobre direito processual (CR, art. 22, inc. I) enquanto que a competência para legislar sobre procedimentos em matéria processual é concorrente entre União, Estados e Distrito Federal (CR, art. 24, inc. XI). Quanto ao Município, sua competência se estabelece nos termos do art. 30, da CR.(grifo do autor)
} 
José Afonso da Silva ${ }^{114}$ observa que o art. 37 da Constituição emprega a expressão Administração Pública em dois sentidos: como conjunto orgânico e como atividade administrativa. Naquele "ao falar em Administração Pública direta e indireta de qualquer dos Poderes da União, dos Estados, do Distrito Federal e dos Municípios”. Neste "quando determina sua submissão aos princípios de legalidade, impessoalidade, moralidade, publicidade, eficiência, da licitação e os de organização de pessoal administrativo."

Considerando que na Constituição da República de 1988 o Estado se constitui em Estado Democrático de Direito (CR, art. $1^{\circ}$ ); considerando que este Estado reconhece inúmeros direitos fundamentais $\left(\mathrm{CR}\right.$, art. $\left.5^{\circ}\right)$, fixa fundamentos e objetivos para o Estado brasileiro (CR, art. $1^{\circ}$ e $3^{\circ}$ ) e também a forma de garanti-los e atingi-los (v.g., CR, do art. 37 ao art. 43); considerando que este reconhecimento também vincula a Administração Pública, pode-se dizer que ela, nesta nova ordem constitucional, é chamada a desenvolver atividades administrativas correlatas à pluralidade destes direitos (econômicos, sociais, culturais etc.) e objetivos (v.g., o de construir uma sociedade livre, justa e solidária - $\mathrm{CR}$, art. $3^{\circ}$, inc. I) de forma democrática.

Atento à sua posição na composição do Estado, o papel da Administração Pública não é pequeno e, seja como for, deverá ser sempre desempenhado de modo impessoal. Ou seja, conformado pelo princípio de impessoalidade.

\subsection{Suas características}

O Direito Administrativo ${ }^{115}$ tem características próprias: é direito público, conjunturalmente mutável, recente, fragmentário, intencionalmente lacunar e aberto e parcialmente codificado.

\footnotetext{
${ }^{114}$ SILVA, José Afonso da. Curso de Direito Constitucional Positivo. $22^{\mathrm{a}}$ ed. revista e atualizada nos termos da Reforma Constitucional - até a Emenda Constitucional n. 39, de 19.12.2002. São Paulo: Malheiros, 2003. p. 635.

${ }^{115}$ Todas as transcrições deste subitem III. 3 são extraídas de SOUSA ,Marcelo Rebelo de; MATOS, André Salgado de. Direito Administrativo Geral - Introdução e princípios fundamentais. $3^{a}$ ed. Portugal: D. Quixote, 2010. p. 64. Tomo 1. pp. 58-61. Especificamente sobre a característica sobre a ausência de codificação, discorrendo sobre a pluralidade de métodos de estudo do direito, José Cretella Júnior registra que "Ao contrário dos diversos ramos da ciência jurídica, em geral contemplados com seus respectivos códigos - Código Civil, Código Comercial, Código Penal, Código de Processo Civil, Código de Processo Penal - isola-se estranhamento o direito administrativo por não oferecer até o presente, salvo raríssimas exceções, aliás discutidas pelos doutrinadores, o correspondente Código Administrativo" (CRETELLA JÚNIOR, J. Tratado de direito administrativo. Vol. I - Teoria do direito administrativo. $2^{\mathrm{a}}$ ed. atual. Rio de Janeiro: Forense, 2002, p. 335).
} 
A caracterização como direito público o distingue do direito privado, e o critério de diferenciação é o do interesse: "ele incide sobre um objecto - a função administrativa - dominado pela ideia de prossecução do interesse público”. Assim nem o critério da natureza dos sujeitos, nem o critério de sua posição são suficientes para se explicar este ramo do direito.

Diz-se que o Direito Administrativo é conjunturalmente mutável porque ele depende das concepções e das estruturas políticas, econômicas, sociais e culturais de seu tempo. E mais, "é ainda vulnerável a mutações acerca da interpretação do interesse público nos sucessivos momentos históricos, dentro da margem não tolhida pela Constituição (por exemplo, uma mesma Constituição instituidora de uma economia de mercado é compatível com opções legislativas por um sector público forte, por uma privatização formal de seguimentos da administração pública ou pela sua privatização material num regime de regulação, cada uma delas implicando um direito administrativo substancialmente diferente)".

Seu caráter de recenticidade, baseia-se no fato de se concebê-lo como "um produto" da Revolução Francesa. "Constituindo hoje dado assente que o direito administrativo liberal não rompeu integralmente com a ordem jurídica do antigo regime, sendo mesmo detectáveis alguns pontos de continuidade (...), a Revolução Francesa marca o momento fundacional do direito administrativo moderno e um entendimento radicalmente novo dos seus sentidos e alcance, em contraste flagrante com os vários ramos do direito privado, particularmente como direito civil, cuja matriz fundacional básica se reconduz directa e, nalguns institutos e regimes jurídicos, ininterruptamente ao direito romano de há mais de dois mil anos.

Como consequência da juventude - pouco mais de duzentos anos - o direito administrativo é ainda muito marcado pelas suas origens, existindo institutos e regimes jurídicos, bem como concepções doutrinárias, apenas compreensíveis à luz da história. Cabe à doutrina exercer a sua atenção sobre tais situações, de modo a discernir se se trata de legados aceitáveis do passado ou de ideias que só mediante repetição acrítica sobreviveram à inevitável mutabilidade da realidade social e do direito que a regula (e que, compreendida a sua essência, poderiam mesmo vir a revelar-se antagônicas em relação a modelo de administração pública vigente)".

O que não dizer de sua natureza fragmentária. A propósito, muito de suas contradições e paradoxos parecem advir desta sua característica. 
Se se conceber que o Direito Administrativo historicamente conviveu com a possibilidade de margens de liberdade de atuação do administrador público, denominado discricionariedade, bem se pode imaginar a luta travada entre os que exerciam o poder e aqueles que deveriam se submeter a ele. Luta esta que, em parte, se baseava na ausência de regulamentação precisa para o agir administrativo.

Sobre esta fragmentariedade, os portugueses Marcelo Rebelo de Souza e André Salgado de Matos afirmam: "Isto significa que [o direito administrativo] não regula de forma rigorosamente (mas apenas tendencialmente) global o exercício da função administrativa. Por outras palavras, o direito administrativo regula fragmentos do seu objecto e não a sua totalidade. Historicamente, a fragmentariedade do direito administrativo explica-se pela circunstância de ter surgido mediante um processo de lenta emancipação em relação ao direito privado, então o direito comum; todavia, de um direito especial ou mesmo excepcional em relação ao direito comum, o direito administrativo evolui para um verdadeiro direito comum da função pública (...). Sem prejuízo da aplicação do direito privado a alguns segmentos da função administrativa, a fragmentariedade do direito administrativo tem actualmente mais que ver com o permanente surgimento de novos sectores da vida social carentes de regulação, ao qual o legislador não consegue muitas vezes responder senão com atraso, imperfeitamente, amiúde através de regimes jurídicos esparsos. Enquanto a consequência tradicional da fragmentariedade era a aplicação subsidiária do direito privado, hoje em dia ela só é admitida muito restritivamente".

Outra característica deste novo ramo do direito, é ser intencionalmente lacunar e aberto, e que parece ter íntima relação com a característica anterior. Ela "decorre da flexibilidade das diferentes configurações do interesse público nos casos concretos. Tornando-se impossível antecipar integralmente tais configurações, as normas de direito administrativo muitas vezes deixam propositadas margens de liberdade à administração pública (e aos demais entes incumbidos da prossecução da função administrativa) quer na fixação de pressupostos da sua actuação, quer na definição dos seus efeitos. Tais margens de liberdade traduzem-se no carácter lacunar da previsão de normas jurídicas e na abertura da sua estatuição (...) Quando actue no exercício de uma liberdade legalmente conferida, a administração pública encontra-se limitada pelos princípios e pelas regras jurídicas vigentes, impendendo sobre ela um dever de recondução valorativa das suas decisões à unidade do sistema jurídico". 
Por fim, mas não menos importante, assunto de muitos escritos de Direito Administrativo, é o fato de que este ramo do direito é "apenas parcialmente codificado", característica esta que de alguma forma tem origem nas características acima mencionadas.

Estas seis características do Direito Administrativo, por certo, são antecedentes que também parecem inspirar o advento do princípio de impessoalidade.

\section{4. Sua importância prática}

Um dos traços caracterizadores da atividade administrativa contemporânea, na lição de Juan Carlos Cassagne ${ }^{116}$, "está dado pela ingerência do Estado em campos antes reservados à iniciativa individual. O Estado de nossos dias não se contenta já em ser um mero espectador passivo do que acontece ao seu redor, mas intervém em novos e variados setores tanto, por exemplo, quando impulsiona e promove o desenvolvimento de atividades vinculadas ao progresso e bem-estar de seus cidadãos como naquelas hipóteses em que realiza uma ação limitativa dos direitos individuais com uma finalidade de interesse público".

O administrativista argentino acrescenta que em consequência do crescimento das atividades administrativas, o Direito Administrativo, "que é seu principal regulador, adquiriu uma importância extraordinária e uma decisiva influência na solução de todas as questões originadas por este fenômeno. Como característica distintiva do direito administrativo destaca-se o papel que cumpre em sua formação os princípios gerais e o fato de que a doutrina exerça influência comparativamente maior que em outras disciplinas em razão desta parte do direito não se ter incorporado ainda, na quase totalidade dos países, ao processo de codificação que abraça a outras matérias jurídicas agrupando suas normas em um corpo orgânico e sistemático. Nessa função criadora de princípios, propor regras e realizar novas interpretações, a doutrina tem hoje em dia a responsabilidade de construir sua ciência em um mundo assinalado por profundos e aceleradas mudanças políticas, sociais e econômicas, donde a invenção do homem desenvolve incessantemente diferentes técnicas e sistemas que exigem uma resposta jurídica satisfatória".

Esta ampliação das atividades da Administração Pública exigirá da Administração Pública uma modificação em seu modo de atuar a fim de que consiga dar respostas jurídicas mais satisfatórias à sociedade. E para a produção de respostas mais satisfatórias da Administração Pública a doutrina terá de se empenhar em reavaliar a

\footnotetext{
${ }^{116}$ CASSAGNE, Juan Carlos. El acto administrativo. Buenos Aires: La Ley, 2012. p. 2 (tradução nossa).
} 
principiologia do Direito Administrativo e isso, por exemplo, passa pela releitura do princípio de impessoalidade.

Este trabalho concebe o Direito Administrativo como um complexo de princípios e regras com um objetivo específico: o direito comum da função administrativa, nos termos explicitados pelos portugueses Marcelo Rebelo de Sousa e André Salgado de Matos $^{117}$. Ou seja, enquanto direito da função administrativa, o Direito Administrativo não regula apenas a atuação da Administração Pública em sentido orgânico; regula também a atuação de todos os sujeitos jurídicos, ainda que não integrantes dela, que exerçam a função administrativa, e ainda a atuação de todo e qualquer sujeito jurídico, quando e na medida em que se interseccione com o exercício da função administrativa.

Embora o Direito Administrativo definitivamente não seja nem panaceia nem pancresto ${ }^{118}$ dos problemas da sociedade brasileira. Ele é, entretanto, uma parte do Direito que mais profundamente expõe o problema do conflito permanente entre a autoridade e a liberdade: o conflito Estado e indivíduo, ordem e liberdade.

Estas ideias sintéticas revelam tensões insolúveis que exigem soluções equilibradas concretas. Mas ainda que se admita a possibilidade de um equilíbrio entre elas - e a aqui a lição é de Agustín Gordillo ${ }^{119}$-, é evidente que a obtenção deste equilíbrio há de ser uma difícil e delicada tarefa porque há muita gente inclinada a construir, não um equilíbrio, mas um sistema a serviço do poder; há muita gente servindo ao poder de turno até no campo da "doutrina". Historicamente se registra primeiro o despotismo estatal sobre os indivíduos; logo em seguida, e como reação, a exacerbação dos direitos dos indivíduos em relação à sociedade; por fim, e como desejo, o equilíbrio fundamentado dos elementos essenciais do mundo contemporâneo livre: indivíduo e sociedade, indivíduo e Estado. Mas esse equilíbrio desejado é inapreensível: o que para uns representa a cômoda solução da tensão é para outros uma submissão ou uma ofensa; essa incerteza tende a se resolver em um autoritarismo constantemente revivido, mostrando-se necessário, assim, buscar o equilíbrio do próprio critério em cuja base estas tensões e contraposições do indivíduo e do Estado serão analisadas.

\footnotetext{
117 SOUSA, Marcelo Rebelo de; MATOS, André Salgado de. Direito Administrativo Geral - Introdução e princípios fundamentais. $3^{\mathrm{a}}$ ed. Portugal: D. Quixote, 2010. p. 64. Tomo 1. p. 55. Isso significa, e a lição também é destes professores, "que não se trata do direito exclusivo da função administrativa: esta pode ainda ser regulada por normas de outros ramos de direitos, designadamente de direito privado".

118 Conforme NOVO AURÉLIO SÉCULO XXI - Dicionário da língua Portuguesa. $3^{\text {a }}$ edição, totalmente revista e ampliada. Rio de Janeiro: Nova Fronteira, 1999. p. 1482, panaceia: "remédio para todos os males" e, em seu sentido figurado, pancresto:"recurso sem nenhum valor empregado para remediar".

${ }^{119}$ GORDILlO, Agustín. Tratado de Derecho Administrativo. Prólogo de Jorge A. Sáenz - Tomo I, Parte Geral. 10ª ed. Buenos Aires: Fundación de Derecho Administrativo, 2009. p. III-1 (tradução livre).
} 
Pode-se dizer que o princípio de impessoalidade é um instrumental que pode contribuir para que estas tensões e contraposições sejam analisadas adequadamente.

O Direito Administrativo adquiriu importância na sociedade contemporânea na medida em que passou a disciplinar considerável parcela de aspectos essenciais da vida em coletividade. No Brasil, isso não é diferente. Ele regula, por exemplo, o fornecimento de energia elétrica, do gás, da água; as atividades das empresas de transportes públicos (ônibus, metro etc.); as atividades das empresas de telefonia, internet; as atividades do comércio, de produção de alimentos, das instituições financeiras (horário de funcionamento, regras de higiene etc.); prestação de serviços de educação, saúde, segurança pública etc. Além disso, também disciplina juridicamente uma infinidade de assuntos: licenciamento de obras; exploração de hospitais públicos por entidades privadas; construção de autoestradas; pagamento de aposentadoria e de indenizações por danos causados pelo Estado etc.

Se esta importância prática é evidente (embora seja possível que o leigo não tenha dado conta disso), não é menor sua relevância teórica, conforme observaram Marcelo Rebelo de Sousa e André Salgado de Matos. "Embora o direito constitucional, do ponto de vista da hierarquia das fontes normativas que constituem o seu objecto de estudo, goze de uma indiscutível primazia, é no direito administrativo que se encontra a generalidade dos quadros conceptuais fundamentais de todo o direito público, incluindo o direito constitucional"120. Tal importância toma relevo dando origem àquilo que os autores portugueses denominam de direitos transversais. Ou seja, "a ultrapassagem da separação liberal entre Estado e sociedade e a emergência do Estado social de Direito conduziram ao aparecimento de sectores da vida social objecto de regulação, quer por normas de direito privado, quer por normas de direito público. Esta realidade, que traduz uma confluência ou concorrência de interesses públicos e privados numa disciplina jurídica, deu origem à autonomização de ramos de direitos transversais, no sentido de atravessarem diversos ramos de direito de fronteiras tradicionalmente delimitadas, como o direito civil, o direito penal e o direito administrativo. Exemplos eloquentes destes novos ramos de direito são o direito do urbanismo e o direito do ambiente, que incorporaram normas de raiz milenar dos direitos reais e normas de direito administrativo (especial) e penal nascidas com o estado social de direito" $" 121$.

\footnotetext{
${ }^{120}$ SOUSA ,Marcelo Rebelo de; MATOS, André Salgado de. Direito Administrativo Geral - Introdução e princípios fundamentais. $3^{\text {a }}$ ed. Portugal: D. Quixote, 2010. p. 35. Tomo 1.

${ }^{121}$ Idem, ibidem. p. 85.
} 


\subsection{Sua função ontem e nos dias atuais}

Em se tratando deste tema, a doutrina ${ }^{122}$ se divide entre aqueles que são partidários de concepções objetivistas e subjetivistas da função do direito administrativo.

"As concepções objectivistas tradicionais têm raízes na própria origem do direito administrativo, que, tanto em França como na Alemanha, surgiu como estatuto de privilégio da administração pública, destinado a colocá-lo ao abrigo dos regimes igualitários do direito privado (...) Nessa medida acentuava-se a essência autoritária da actuação administrativa e o caráter exorbitante dos poderes que a ordem jurídica lhe conferia: a função do direito administrativo seria precisamente a de possibilitar o exercício de poderes de autoridade pela administração pública, de modo a permitir-lhe impor os interesses públicos que visasse prosseguir sobre os interesses privados que com ele concretamente se confrontassem. No Estado social de direito, tal concepção primeiro prédemocrática, depois antidemocrática e autoritária, deve considerar-se afastada pela configuração do estatuto constitucional da administração pública e pela consagração de inúmeros direitos fundamentais dos cidadãos oponíveis à administração, conducentes a uma inevitável relativização do interesse público".

Marcelo Rebelo de Souza e André Salgado de Matos concluem que "Modernamente os defensores de teorias objectivistas afirmam que, embora naturalmente com respeito pelas posições jurídicas subjectivistas dos particulares, o direito administrativo visa primacialmente conferir à administração pública os meios necessários para que ela prossiga da melhor forma os interesses públicos que lhe são cometidos. Tais meios poderão ou não implicar o exercício de poderes de autoridade, bem como implicar limites específicos tendentes a manter a actuação da administração pública dentro das fronteiras tidas por desejáveis".

Por sua vez, observando que a tese subjetiva nasce como uma reação à tese objetiva, os administrativistas portugueses afirmam que os defensores das teses subjetivistas "consideram que a função administrativa do direito administrativo é a de garantir a preservação das posições jurídicas dos particulares perante a actuação administrativa, à qual - para além da supremacia que lhe é prototipicamente reconhecida

122 Todas as transcrições deste subitem III.5 são extraídas de Direito Administrativo Geral - Introdução e princípios fundamentais, SOUSA, Marcelo Rebelo de; MATOS, André Salgado de. Direito Administrativo Geral - Introdução e princípios fundamentais. $3^{\mathrm{a}}$ ed. Portugal: D. Quixote, 2010. p. 61-63. Tomo 1. 
por lei, em homenagem aos interesses públicos que prossegue - se associa, por vezes, uma tendência quase imanente para a adoção de comportamentos autoritários, limitadores das esferas individuais e nas franjas da juridicidade".

Cremos, como na linha do pensamento destes autores portugueses, que a visão purista de quaisquer destas concepções administrativas de mundo não tem razão de ser, "devendo antes atribuir-se ao direito administrativo uma função verdadeiramente mista, objectiva e subjectiva".

E a razão é simples. Se por um lado, a visão puramente objetiva "é insustentável perante a consagração de direitos fundamentais (...) e perante o estabelecimento da vinculação da administração pública aos direitos fundamentais em geral"; de outro, a visão puramente objetiva "deixa na sombra a ideia fundamental de prossecução do interesse público, inerente à função administrativa, e comete o erro de ver a administração pública democraticamente legitimada do Estado social de direito como um prolongamento da administração autoritária e antidemocrática do Estado Liberal”.

Fazendo, enfim um pequeno reparo à lição destes autores portugueses, o Direito Administrativo não é nem $d a$ Administração Pública, nem dos cidadãos. Ele é para ambos, "a sua função é a de permitir a prossecução do interesse público no respeito das posições jurídicas subjetivas dos particulares". 


\section{IV - O PRINCÍPIO DE IMPESSOALIDADE NA DOUTRINA BRASILEIRA}

A doutrina brasileira de fato não apresenta consenso sobre o que vem a ser o princípio de impessoalidade e o interpreta de maneiras diversas.

O conceito do princípio varia de acordo com a perspectiva adotada pelos doutrinadores. E em todas elas o princípio não tem autonomia ou conteúdo distintivo de outros princípios do ordenamento jurídico.

Muitos autores citam o art. 37, §1 ${ }^{\circ}$, da Constituição da República, como exemplo da incidência do princípio de impessoalidade. Tal dispositivo estabelece que: “A publicidade dos atos, programas, obras, serviços e campanhas dos órgãos públicos deverá ter caráter educativo, informativo ou de orientação social, dela não podendo constar nomes, símbolos ou imagens que caracterizem promoção pessoal de autoridade ou servidores públicos".

Por certo tal compreensão - ao que parece equivocada ${ }^{123}$ - está associada à expressão "pessoal” contida no dispositivo constitucional.

Em síntese, existem aqueles que o compreendem como expressão única de um princípio já conhecido - como igualdade, como finalidade ou como imparcialidade - embora possam relacioná-lo a outras ideias como sendo seu corolário; e outros que mesclam noções destes princípios com as de outros também já conhecidos - v.g., moralidade e publicidade - ou ainda com alguma outra característica - imputação, neutralidade, objetividade etc. - deixando ainda maior a ambiguidade conceitual.

A classificação seguinte leva em conta aquilo que pareceu preponderar da exposição feita pelos autores pesquisados, não havendo a pretensão de uma sistematização mais criteriosa.

\footnotetext{
123 Diz-se equivocada porque se associou de forma acrítica a expressão "pessoal" com o termo "impessoalidade". Como se, por exemplo, pudéssemos dizer, mutatis mutandis, que a expressão "livre" do inc. II, do art. 37, da CR ('... declarado em lei de livre nomeação e exoneração') tivesse alguma relação com o direito de liberdade, reconhecido no art. $5^{\circ}$, caput, da CR. Ou ainda que a expressão "confiança" contida no inc. V, do art. 37, da CR ('as funções de confiança') tivesse alguma relação com o princípio de confiança legítima que a doutrina administrativista tem sustentado, por influência do direito alemão (DI PIETRO, Maria Sylvia Zanella. Direito Administrativo. 25a ed. São Paulo: Atlas, 2012. p. 86-87).
} 
4. 1. A impessoalidade como concepção única

4.1.1. A impessoalidade como finalidade (ou interesse público)

Hely Lopes Meirelles ${ }^{124}$ compreende o princípio de impessoalidade como o princípio da finalidade.

Mais precisamente ele anota que o princípio de impessoalidade que está “(...) referido na Constituição de 1988 (art. 37, caput), nada mais é que o clássico princípio da finalidade, o qual impõe ao administrador público que só pratique o ato para o seu fim legal. E o fim legal é unicamente aquele que a norma de Direito indica expressa ou virtualmente como objetivo do ato, de forma impessoal.

Esse princípio também deve ser entendido para excluir a promoção pessoal de autoridades ou servidores públicos sobre suas realizações administrativas (CF, art. $\left.37, \S 1^{\circ}\right)$.

E a finalidade terá sempre um objetivo certo e inafastável de qualquer ato administrativo: o interesse público. Todo ato que se apartar desse objetivo sujeitar-se-á a invalidação por desvio de finalidade, que a nossa lei da ação popular conceituou como o 'fim diverso daquele previsto, explícita ou implicitamente, na regra de competência' do agente (Lei $4.717 / 65$, art. $2^{\circ}$, parágrafo único, 'e’) (...)

O que o princípio da finalidade veda é a prática de ato administrativo sem interesse público ou conveniência para a Administração, visando unicamente a satisfazer interesses privados, por favoritismo ou perseguição dos agentes governamentais, sob a forma de desvio de finalidade".

Concebendo o princípio também como finalidade, Paulo Alberto Pasqualine $^{125}$, que revisou e reelaborou Princípios de Direito Administrativo, de Ruy Cirne Lima, referiu-se a ele como "decorrência do princípio de utilidade pública". Sobre a

\footnotetext{
${ }^{124}$ MEIRELLES, Hely Lopes. Direito Administrativo Brasileiro. $21^{\mathrm{a}}$ ed. Atualizada por Eurico de Andrade Azevedo, Délcio Balestero Aleixo e José Emmanuel Burle Filho. São Paulo: Malheiros, 1996. p. 85-86. Nesta $21^{\text {a }}$ edição o título vem como sendo "Impessoalidade e finalidade"; contudo, na $39^{\mathrm{a}}$ edição, atualizada até a emenda Constitucional 71, de 29.11.2012, agora por Délcio Balestero Aleixo e José Emmanuel Burle Filho, p. 95-96, registrou-se "Impessoalidade ou finalidade", com o acréscimo de que "do exposto, constatase que o princípio em foco está entrelaçado com o princípio da igualdade (art. $5^{\circ}$, I,e 19, III, CF), o qual impõe à Administração Pública tratar igualmente a todos os que estejam na mesma situação fática e jurídica". Anote-se que nas duas edições mencionadas, p. 82 e 90, respectivamente, Hely Lopes afirma que "A Constituição de 1988 não se referiu expressamente ao princípio da finalidade, mas o admitiu sob a denominação de princípio da impessoalidade (art. 37)".

${ }^{125}$ LIMA, Rui Cirne. Princípios de Direito Administrativo $7^{\mathrm{a}}$ ed., revista e reelaborada por Paulo Alberto Pasqualini. São Paulo: Malheiros, 2007. p. 54 e 24.
} 
utilidade pública, registrou-se que ela "dá-nos, por assim dizer, o traço essencial do Direito Administrativo. A utilidade pública é a finalidade própria da Administração Pública, enquanto 'provê à segurança do estado, à manutenção da ordem pública e à satisfação de todas as necessidades da sociedade' (Pereira do Rego, Elementos de Direito Administrativo Brasileiro, 1860, §4, p.2)”.

Em monografia sobre o princípio, Lívia Maria Armentano Koenigstein Zago $^{126}$, depois de relacionar a compreensão que autores nacionais e internacionais possuem sobre o princípio de impessoalidade, a ligação dele com o Estado-Poder e com outros princípios constitucionais, observou que a impessoalidade comportava vários significados e denominações, realçando seu traço político, mas refere-se ao princípio de impessoalidade como estando relacionado ao princípios da finalidade, acrescentando que ele tem a função de impor condutas (avoca o sentido de dever) e também garantir direitos (traz o sentido de objetividade, possibilitando a transparência, a igualdade, a eficiência, responsabilidade).

Observa esta autora que a "vedação de subjetivismo, de privilégios, de perseguições e de arbitrariedade constitui a característica fulcral, o busílis do princípio da impessoalidade, seu traço marcante e destacado, em qualquer época e sob qualquer denominação. Esta característica é que imprime ao princípio da impessoalidade seu sentido ético, que o entrelaça e identifica de maneira muito estrita e especial a outros princípios jurídicos (...) Assim, o princípio da impessoalidade significa atuação objetiva e neutra, primordial e exclusivamente voltada para o fim do interesse público, cujo objetivo principal consiste na vedação do arbítrio e do dirigismo oposto ao do interesse público comum, seja com vistas ao obséquio, seja com vistas ao prejuízo" ${ }^{127}$.

No que diz respeito à relação do princípio com o poder, ela observa que o princípio da impessoalidade "visa a arredar a identificação do poder com a pessoa física do governante. É, pois, princípio conformador, informador e axiológico dos Estados Modernos de Direitos"

Após apontar várias interpretações sobre o princípio encontrados na doutrina brasileira (chamando-as de "cinco teorias" sobre o princípio) e rebatê-las uma a

\footnotetext{
${ }^{126}$ ZAGO, Lívia Maria Armentano Koenigstein. O princípio da impessoalidade. Rio de Janeiro: Renovar, 2001. p.179.

${ }^{127}$ Idem, ibidem. p. 179

${ }^{128}$ Idem, ibidem. p. 383.
} 
uma, Fábio Lins de Lessa Carvalho ${ }^{129}$ concebe o princípio à maneira de Lívia Maria Armentano Koenigstein. O autor registra que a "impessoalidade possui extrema riqueza de conteúdo. Cada uma das correntes analisadas focaliza um determinado aspecto do princípio, todos igualmente preocupados em reforçar o compromisso que deve ser assumido pelo administrador público, que se traduz nas seguintes tarefas: exercer um encargo, cumprir uma função, desincumbir-se de uma missão, servir ao público, realizar um projeto popular".

Em seguida, ele conclui que "Todas essas prescrições foram resumidas por Lívia Maria Armentano Koenigstein nos seguintes termos: 'A vedação de subjetivismo, de privilégios, de perseguições e de arbitrariedade constitui a característica fulcral, o busílis do princípio da impessoalidade, seu traço marcante e destacado, em qualquer época e sob qualquer denominação. Esta característica é que imprime ao princípio da impessoalidade seu sentido ético, que o entrelaça e identifica de maneira muito estrita e especial a outros princípios jurídicos..."”.

Parece ser esta também a compreensão que José Nilo de Castro ${ }^{130}$ tem do princípio de impessoalidade. Para ele, este princípio "se traduz na consecução da finalidade pública, vedando expressamente quaisquer inclinações ou interesses pessoais na prática do ato, de forma a lhe garantir a impessoalidade, imparcialidade e neutralidade".

A propósito, este autor acrescenta que "É da tradição vigorosa de nosso regime republicano, acumulada desde a Carta de 1891, a sujeição da Administração Pública (aí compreendidos todos os Poderes) ao princípio da impessoalidade, em virtude do qual as funções estatais se ligam a finalidades públicas impessoais, metaindividuais, objetivas. A estatal é impessoal, não pode ser orientada por interesses pessoais, quer do agente, quer do particular".

Irene Patrícia Nohara ${ }^{131}$ inclui-se entre aqueles que associam o princípio ao princípio da finalidade. Mencionando o entendimento de vários doutrinadores e admitindo que os fundamentos ("finalidade, teoria do órgão, imparcialidade e igualdade") utilizados por eles eram indissociáveis, observa que "o agente público não pode praticar atos senão para satisfazer interesses públicos, sendo vedado o uso da máquina

\footnotetext{
${ }^{129}$ CARVALHO, Fábio Lins de Lessa. O princípio da impessoalidade nas licitações. Maceió: EDUFAL, 2005. p. 70

${ }^{130}$ CASTRO, José Nilo de. Direito Municipal Positivo. $6^{\text {a }}$ ed. revisada e atualizada. Belo Horizonte: Del Rey, 2006. p.506.

${ }^{131}$ NOHARA, Irene Patrícia. Direito Administrativo. São Paulo: Atlas, 2011. p. 70-72.
} 
administrativa, custeada pela res publica, para o alcance tão somente da interesses próprios ou de terceiros".

Mais adiante afirma que "a consecução dos fins de interesse público deve guiar a atividade administrativa, na qual a manifestação da vontade estatal, pela teoria do órgão, não pode se confundida com a vontade subjetiva do agente público que deve agir de forma imparcial, tratando a todos sem discriminações arbitrárias".

Pelo que se infere de sua argumentação, Marcio Pestana ${ }^{132}$ se inclui entre aqueles que, considerando ter o princípio de impessoalidade uma "textura aberta, passível de ser saturada sob diversas acepções, como de identidade com o princípio da igualdade, atrelado ao princípio de finalidade”, compreende-o como sendo o princípio de finalidade. É, pois, o que se observa de sua afirmação no sentido de que “o princípio da impessoalidade, a nosso ver, direciona-se certeiramente para os atos administrativos da espécie discricionária, conferindo-lhes um vetor axiológico no sentido de determinar, ao agente público, que a decisão que se encontra prestes a ser tomada deverá sê-lo em obséquio ao interesse público, e não em favor deste ou daquele interesse ou preferência pessoal (...) Há, contudo, outra acepção que nos parece apropriada para este princípio de tão largo espectro (...) percebe-se que o princípio da impessoalidade tem aplicabilidade clara no sentido de vedar a vinculação entre entidade-agente, ou seja, da personalização e do enaltecimento, com foros muita das vezes de excesso a destaque de qualidades, virtudes e realizações, das pessoas físicas que, sob o manto da condição jurídica de agente público, são os efetivos instrumentalizadores e promoters dos atos de competência da entidade pública a que pertencem ou à qual estão voltados”.

Em Reflexões acerca do princípio da impessoalidade ${ }^{133}$, Bernardo Strobel Guimarães, após examinar doutrina estrangeira e nacional, parece compreender o princípio como relacionado ao princípio de finalidade. Ao pretender fixar seu conteúdo, afirma que "Primeiramente, o princípio fixa um objetivo a ser atingido: a Administração deve ser exercida pelos seus agentes, independentemente de suas preferências pessoais, ficando salvaguardada de interesses que lhe são alheios. Aí, tem-se uma eficácia teleológica que tipicamente se caracteriza como pertinente a um princípio, pois se pretende promover um estado a ser atingido (justamete, a Administração impessoal), o que acaba por orientar a interpretação a ser dada a outras normas que remetem à ideia de

${ }^{132}$ PESTANA, Márcio. Direito Administrativo Brasileiro. $3^{\mathrm{a}}$ ed. Rio de Janeiro: Elsevier, 2012. p. 205-206.

133 GUIMARÃES, Bernardo Strobel. Princípios de direito administrativo: legalidade, segurança jurídica, impessoalidade, publicidade, motivação, eficiência, moralidade, razoabilidade, interesse público. In MARRARA, Tiago (org). São Paulo Atlas, 2012. p. 133-147. 
impessoalidade, bem como servir de norte a medidas legais e administrativas que visem a promoção desse estado ideal de coisas”.

$\mathrm{E}$, ao final da parte de seu texto, no item intitulado $O$ conteúdo do princípio da impessoalidade, este autor conclui que "Qualquer ação em que um servidor ponha seus interesses acima daqueles acolhidos pelo sistema será reprovável à luz do conteúdo que diretamente se extrai do princípio da impessoalidade".

Por fim, registre-se que embora faça menção à doutrina de Lúcia Valle Figueiredo, de Juarez de Freitas e de Cármen Lúcia Antunes Rocha, Marino Pazzaglini Filho ${ }^{134}$ acaba por concluir que o princípio está relacionado ao de finalidade. É o que se observa desta sua afirmação: "Portanto, a atuação da Administração Pública deve pautar-se sempre pelo interesse público, o que vale dizer, pela objetividade e pela neutralidade no atendimento às necessidades do grupo social, imune não só às marcas particulares como aos liames políticos e de índole pessoal do agente público que a exerça”.

\subsubsection{A impessoalidade como igualdade (ou isonomia)}

Adilson de Abreu Dallari ${ }^{135}$, discorrendo sobre Licitação, afirma que "o Princípio da Impessoalidade outra coisa não é senão uma transmudação para o âmbito da administração pública do mesmo Princípio da Igualdade afirmado anteriormente, o qual, por sua vez, deriva da ideia de República. Ou seja, em face do texto da Constituição, não há possibilidade alguma de se contestar a afirmação de que a licitação é um princípio constitucional. (...)

Por força da República, do Princípio da Isonomia e do Princípio da Impessoalidade, é forçoso extrair da Constituição um 'Princípio da Licitação'. Em princípio, todos os contratos celebrados pela administração pública devem ser precedidos de licitação, porque a administração pública nãopode nem privilegiar, nem prejudicar quem quer que seja, mas deve oferecer iguais oportunidades a todos de contratar com ela. Esta é a regra geral"

\footnotetext{
${ }^{134}$ PAZZAGLINI FILHO, Marino. Princípios constitucionais regulares da administração pública: agentes públicos - discricionariedade administrativa, extensão da atuação do Ministério Público e do controle do poder judiciário. $2^{\mathrm{a}}$ ed.São Paulo: Atlas, 2003. p. 27.

${ }^{135}$ Licitação. In Direito administrativo na Constituição de 1988. BANDEIRA DE MELLO, Celso Antônio (coordenador). São Paulo: Revista dos Tribunais, 1991, p. 119.
} 
Celso Antônio Bandeira de Mello ${ }^{136}$ reconhece o principio como sendo o próprio princípio de igualdade ou isonomia.

O professor se manifesta nos seguintes termos: "Nele se traduz a idéia de que a Administração tem que tratar a todos os administrados se discriminações, benéficas ou detrimentosas. Nem favoritismo nem perseguição são toleráveis. Simpatias ou animosidades pessoais, políticas ou ideológicas não podem interferir na atuação administrativa e muito menos interesses sectários, de facções ou grupos de qualquer espécie. O princípio em causa não é senão o próprio princípio da igualdade ou isonomia. Está consagrado explicitamente no art. 37, caput, da Constituição. Além disso, assim como 'todos são iguais perante a lei' (art. 50, caput), a fortiori teriam de sê-lo perante a Administração".

Edmir Netto de Araújo ${ }^{137}$, após analisar conceitos de Celso Antônio Bandeira de Mello, de Lúcia Valle Figueiredo e de Hely Lopes Meirelles, fazendo menção aos professores Maria Sylvia Zanella Di Pietro e José Afonso da Silva, conclui que "em qualquer dos casos, no entanto, não vemos como não se possam encaixar os conceitos e hipóteses no âmbito do princípio de igualdade”.

Diógenes Gasparini ${ }^{138}$ entende o princípio como equivalente ao princípio de igualdade. "A atividade administrativa deve ser destinada a todos os administrados, dirigida aos cidadãos em geral, sem determinação de pessoa ou discriminação de qualquer natureza. É o que impõe este princípio ao Poder público. Com ele quer-se quebrar o velho costume do atendimento do administrado em razão de seu prestígio ou porque a ele o agente público deve alguma obrigação".

Antes de se referir ao pensamento de outros doutrinadores sobre o princípio em questão, Diógenes Gasparini observou que "tem toda razão Wolgran Junqueira Ferreira (Comentários à Constituição de 1988, Julex, 1989, v. 1, p. 452) quando afirma que 'a impessoalidade, isto é, o ato administrativo, não deve ser elaborado tendo como objetivo a pessoa de alguém. Não pode ser dirigido com o intuito de beneficiar esta ou aquela pessoa, esta ou aquela empresa. Caso típico de pessoalidade que deve sofrer sanção do Direito Administrativo foi a concorrência para a construção da ferrovia nortesul, onde já se sabia com antecedência os ganhadores das 'concorrências públicas' de todos

\footnotetext{
${ }^{136}$ BANDEIRA DE MELLO, Celso Antônio. Curso de Direito Administrativo. $21^{\mathrm{a}}$ ed. revista e atualizada até a Emenda Constitucional 52, de 8.3006. São Paulo: Malheiros, 2006. p. 110.

137 ARAÚJO, Edmir Netto de. Curso de Direito Administrativo. $3^{\mathrm{a}}$ ed. revista, ampliada e atualizada. São Paulo: Saraiva, 2007. p. 56.

${ }^{138}$ GASPARINI, Diógenes. Direito Administrativo. 12 a edição revista e atualizada. São Paulo: Saraiva, 2007. p.9.
} 
os trechos, pois foi usado o critério pessoal ao invés da impessoalidade que ora a Constituição obriga'. É óbvio que esse princípio não impede que certos atos administrativos tenham um beneficiário, como é o caso do ato de nomeação de servidor público".

Em texto intitulado Princípio da impessoalidade ${ }^{139}$, o professor Fernando Dias Menezes de Almeida associa o princípio à ideia de igualdade. Partido do exame da noção de legalidade, apontando seu sentido material e formal, ele argumenta que "há o sentido material de legalidade, que remete à noção de lei enquanto suporte de norma geral e abstrata.

O sentido material de legalidade é o que traduz juridicamente de modo mais imediato o valor da igualdade, resultando na noção de impessoalidade (...)

A essência da impessoalidade, portanto, está no fato de o tratamento dado pelos agentes estatais aos casos individuais e concretos estar fundamentado numa decisão anterior geral e abstrata".

Aluizio Bezerra Filho ${ }^{140}$, embora faça menção a "regra de impessoalidade", inclui-se entre aqueles que concebem o princípio de impessoalidade relacionado ao princípio de igualdade. É, pois, o que se observa quando afirma que "a regra de impessoalidade determina que os administrados e as pessoas em geral sejam tratadas em igualdade de condições para a regência de atuação da atuação da gestão pública seja voltada para a satisfação coletiva, sem distinção entre os indivíduos que são, no regime democrático, os titulares do poder (...) A impessoalidade pressupõe a imparcialidade do agente público na implementação dos atos administrativos para que os destinatários recebam tratamento igualitário".

\subsubsection{A impessoalidade como imparcialidade}

Após asseverar que à primeira vista seria possível inferir que o princípio de impessoalidade se consubstancia no princípio da igualdade, Lúcia Valle Figueiredo ${ }^{141}$ argumenta que não é isso o que ocorre. Partindo da acepção do Dicionário André Lalande para o verbete "impessoal” e com apoio na doutrina de Massimo Severo Giannini, ela

\footnotetext{
139 ALMEIDA, Fernando Dias Menezes de. Princípios de direito administrativo: legalidade, segurança jurídica, impessoalidade, publicidade, motivação, eficiência, moralidade, razoabilidade, interesse público. In MARRARA, Tiago (org). __ . São Paulo Atlas, 2012. p. 109-118.

140 BEZERRA FILHO, Aluizio. Lei de improbidade administrativa. Curitiba: Juruá, 2006. p. 28-29.

${ }^{141}$ FIGUEIREDO, Lúcia Valle. Curso de direito administrativo. $8^{\mathrm{a}}$ ed. revista, ampliada e atualizada até a emenda Constitucional 52/2006. São Paulo: Malheiros, 2006. p. 63-64.
} 
anota que "a impessoalidade caracteriza-se, pois, na atividade administrativa, pela valorização objetiva dos interesses públicos e privados envolvidos na relação jurídica a se formar, independentemente de qualquer interesse político".

Na sequência, a autora observa que "a impessoalidade implica-se, refrisese, o estabelecimento de regra de agir objetiva para o administrador, em todos os casos. Assim, como exemplo curial, em nomeações para determinado cargo em comissão, os critérios da escolha devem ser técnicos, e não de favoritismos ou ódios. Não pode a nomeação ser prêmio atribuído ao nomeado, como, também, não pode haver impedimento a nomeações por idiossincrasias".

Por fim, partindo do dicionário Aurélio Buarque de Holanda, conclui que "Impessoalidade é, por conseguinte, imparcialidade, qualidade de ser imparcial, de 'julgamento desapaixonado, que não sacrifica a sua opinião à própria conveniência, nem às de outrem' (Aurélio Buarque de Holanda)".

Juarez de Freitas ${ }^{142}$ também compreende o princípio como sendo o da imparcialidade, referindo-se a ele como "O princípio da imparcialidade ou impessoalidade", com a observação de que a imparcialidade deriva do princípio de igualdade.

Mais incisivamente, Juarez de Freitas afirma que "o princípio da imparcialidade (que o constituinte preferiu denominar princípio da impessoalidade) deriva do princípio geral da igualdade. Mister traduzi-lo como vedação constitucional de toda e qualquer discriminação antijurídica, negativa e atentatória contra os direitos fundamentais e, noutra faceta, como obrigação de reduzir as desigualdades iníquas, nos termos do art. $3^{\circ}$ da CF. Em outra dicção, quer-se 'objetividade no atendimento do interesse público, vedada a promoção pessoal de agentes ou autoridades'. (...)

Segundo o princípio em tela, a Administração Pública precisa dispensar tratamento isonômico a todos, sem privilégios espúrios, tampouco manobras persecutórias, sequer as movidas por supostas boas intenções. Intenta-se a instauração, acima de sinuosos personalismos do governo dos princípios e dos objetivos fundamentais, em lugar do idiossincrático império 'emotivista' dos projetos de cunho faccioso, antagônicos, por definição, à filosofia da boa administração".

\footnotetext{
${ }^{142}$ FREITAS, Juarez de. O Controle dos Atos Administrativos e os princípios fundamentais. $4^{\mathrm{a}}$ ed. refundida e ampliada. São Paulo: Malheiros, 2009. p. 82.
} 
Em monografia sobre o princípio da impessoalidade, Ana Paula Oliveira Ávila ${ }^{143}$, discorrendo sobre a concepção de vários autores sobre o tema, ensina que "o conteúdo do princípio da impessoalidade não se esgota na vedação de tratamento discriminatório pela Administração e na imputação da autoria do ato administrativo ao ente estatal. A noção de impessoalidade abarca noções de objetividade, imparcialidade, neutralidade e transparência da Administração".

E mais, que "a impessoalidade restará explicada como o princípio que impõe à Administração o dever de respeitar o direito de igualdade dos Administrados e de não se valer da máquina pública para lograr proveito pessoal ou de outrem; o dever de proceder com objetividade na escolha dos meios necessários para a satisfação do bem comum; o dever de imparcialidade do administrador quando da prática de atos e decisões que afetem interesses privados ou que ponham termo a conflito de interesses privados perante a Administração, e, inclusive, na decisão sobre o conteúdo dos interesses públicos em concreto; o dever de neutralidade do administrador, que deve caracterizar a postura institucional da Administração e determinar aos agentes públicos o dever de não deixar que suas convicções políticas, partidárias ou ideológicas interfiram no desempenho de sua atividade funcional; e, ainda, na sua exteriorização, o dever de transparência.

Encontram-se, portanto, na impessoalidade, uma faceta impositiva de deveres de conduta para a Administração Pública e uma outra faceta limitadora da atividade administrativa. Surgem limites para a atividade discricionária, que fixam parâmetros decisórios para a determinação do interesse público, para a condução do processo administrativo e para a solução de conflitos entre interesses privados que se ponham perante a Administração".

Mais adiante, na segunda parte da monografia intitulada Impessoalidade como Imparcialidade, a autora observa que "a própria definição de impessoalidade abrange, portanto, a de imparcialidade, permitindo que as duas denominações refiram a mesma idéia: a necessidade de atuações e tomada de decisões desinteressadas, isentas e objetivamente orientadas"144. Ao final, em conclusões, a autora declara que "o dever de imparcialidade surge como o mais importante aspecto do princípio da impessoalidade administrativa, porque impõe uma determinada postura aos agentes administrativos que lidam com os interesses dos administrados, em praticamente toda a extensão da atividade

${ }^{143}$ CARVALHO, Fábio Lins de Lessa. O princípio da impessoalidade nas licitações. Maceió: EDUFAL, 2005. p. 25-26.

144 ÁVILA, Ana Paula Oliveira. O princípio da impessoalidade da administração pública: para uma administração imparcial. Rio de Janeiro: Renovar, 2004. p. 107-108. 
administrativa. Reforça para os agentes públicos a necessidade de desempenhar o munus público com o desinteresse que lhe deve servir de nota distintiva e impõe-lhes o dever de agir de maneira isenta e objetiva".

Percebe-se, então, que para esta autora, em estudo mais aprofundado do que os demais autores citados, o princípio de impessoalidade está relacionado essencialmente à noção de imparcialidade, a um dever de imparcialidade.

Após se referir a vários doutrinadores nacionais e afirmar que o princípio de impessoalidade no direito brasileiro "é tradicionalmente visto sobre duas vertentes proibitivas" - que "veda a imputação de atos estatais ao servidor responsável pela sua prática, porquanto se vinculam ao próprio órgão ou entidade pública de onde se originou” e aquela que "veda a atuação administrativa marcada por perseguição ou favoritismo, a sabor da inimizade/amizade do agente público com a parte interessada" -, em um texto rico de informações históricas, Cristina Andrade Melo ${ }^{145}$, observando que no Brasil "utiliza-se largamente o termo impessoalidade" e que a "maior parte da doutrina sequer menciona o termo "imparcialidade", salienta que em seu trabalho a concepção do princípio tem a mesma daquela adotada por Ana Paula Oliveira Ávila. Mais precisamente que "a noção de imparcialidade está incluída no âmbito de incidência do princípio da impessoalidade. Essa dimensão ampla do princípio, com alcance dos deveres conexos da objetividade, neutralidade, imparcialidade e transparência, é adotada no presente trabalho, na linha defendida por Ana Paula Oliveira Ávila”.

Onofre Alves Batista Júnior ${ }^{146}$ também compreende o princípio como sendo o princípio de imparcialidade. Embora faça menção a vários doutrinadores, o autor parece adotar o entendimento de Cármen Lúcia Antunes Rocha, e afirma, trançando distinções entre os princípios de impessoalidade e o de igualdade, que o princípio "impõe a retirada de marcas pessoais do administrador, exigindo sua neutralidade na atuação administrativa, colocando para a Administração uma diretriz maior: o bem comum (...) veicula para a Administração mandamento de imparcialidade na atuação administrativa, isto é, à luz da CRFB/88, a atuação da Administração é informada pelo princípio da

\footnotetext{
${ }^{145}$ MELO, Cristina Andrade. O princípio da impessoalidade - Audiência pública como contributo à imparcialidade na atuação estatal. In BATISTA JÚNIOR, Onofre Alves; CASTRO, Sérgio Pessoa de Paula. (coords.). Tendências e perspectivas do Direito Administração: uma visão da escola mineira. Belo Horizonte: Fórum, 2012. p. 288-305.

146 BATISTA JÚNIOR, Onofre Alves. Transações Administrativas: um contributo ao estudo do contrato administrativo como mecanismo de prevenção e terminação de litígios e como alternativa á atuação administrativa autoritária, no contexto de uma administração pública mais democrática. São Paulo: Quartier Latin, 2007. p. 133-136.
} 
imparcialidade, que impõe a necessidade de o administrador público agir, neutra e objetivamente, apenas visando à finalidade maior de atender ao bem comum".

Discorrendo sobre improbidade administrativa, no subitem imparcialidade administrativa, Fábio Medina Osório ${ }^{147}$ parece conceber o princípio de impessoalidade relacionado à noção de imparcialidade. Embora elabore inúmeras observações sobre "impessoalidade", anota que a "impessoalidade é a exigência de que o administrador, o agente público, não marque sua atividade administrativa pela perseguição de fins particulares, motivações egoísticas, ambições pessoais que se sobreponham ao interesse público (...) A exigência de impessoalidade está contemplado na LGIA como suporte da probidade, e aqui temos muito claro que a imparcialidade resulta envolta neste princípio constitucional (art. 37, caput, da CF), mas é evidente que nem toda ofensa àquele princípio resultará improbidade administrativa".

Em trabalho jurídico intitulado Principio da Impessoalidade, Renata Porto de Adri Rosa ${ }^{148}$, após mencionar vários doutrinadores, parece acolher a compreensão que Lúcia Valle de Figueiredo - que faz menção ao que se poderia chamar de princípio de imparcialidade nas Constituições da Itália (art. 97), Portugal (art. 267) e Espanha (art. 103) - tem sobre o princípio, para considerá-lo assemelhado ao princípio de imparcialidade. Embora não o faça na conclusão do trabalho, antes dela a autora registra que "concluímos que os termos impessoalidade e imparcialidade se assemelham, tanto pelo contexto em que estão situados nas respectivas Cartas Magnas, como pelo conteúdo semântico que explicitam, reforçando a ideia de que há influência do ordenamento europeu na introdução do princípio da impessoalidade contido na Constituição Federal brasileira”.

Aliás, esta autora dá entender que as Constituições italiana, portuguesa e espanhola exercem "influência nítida em nosso sistema"149

\footnotetext{
147 OSÓRIO, Fábio Medina. Teoria da improbidade administrativa: má gestão pública; corrupção; ineficiência - prefácio de Eduardo Garcia de Enterría. $3^{\text {a }}$ ed. São Paulo: Editora Revista dos Tribunais, 2013. p. 133. Para o autor a sigla LGIA significa Lei Geral de Improbidade Administrativa.

${ }^{148}$ ROSA, Renata Porto de Adri. Princípio de Impessoalidade. In et al - prefácio de Lúcia Valle Figueiredo. Princípios Informadores do Direito Administrativo. São Paulo: Editora NDJ, 1997. p. 36.

${ }^{149}$ Idem, ibidem. p. 35.
} 
4.1.3.1.A influência europeia para a concepção do princípio como sendo o de imparcialidade

Especificamente sobre o princípio da imparcialidade, em Portugal, Maria Teresa de Melo Ribeiro ${ }^{150}$, após examinar vários autores administrativistas e constitucionalistas portugueses, observou que, naquele país ${ }^{151}$, há uma tendência de se dar ao princípio da imparcialidade um sentido amplo e abrangente, com conteúdo positivo e negativo. No aspecto positivo, a Administração Pública tem o dever de ponderar todos os interesses legalmente relevantes no caso concreto para decidir, enquanto que o sentido negativo resulta como a proibição de favoritismos. E mais, há uma tendência de confundir este princípio com o princípio da igualdade, da proporcionalidade e de justiça.

Esta autora adota a posição daqueles que dão ao princípio da imparcialidade um duplo conteúdo: "negativo, quando afasta do exercício da função administrativa todos os interesses estranhos ao interesse público, e, mais precisamente, ao interesse público específico fixado em lei e para cuja prossecução o poder é atribuído à Administração; positivo, quando impõe a ponderação dos diversos interesses juridicamente protegidos e presentes no caso a conformar" ${ }^{\text {"152 }}$. Mais adiante, ela conclui: "Em suma, o princípio da imparcialidade traduz-se na prossecução objetiva, exclusiva e transparente do interesse público definido por lei, através da ponderação de todos os interesses públicos e privados juridicamente relevantes na situação a conformar"153.

Em outras palavras, esta autora portuguesa parece mesmo associar o principio da imparcialidade ao da legalidade e ao da finalidade ao concluir sua dissertação

\footnotetext{
${ }^{150}$ RIBEIRO, Maria Teresa de Melo. O Princípio da Imparcialidade da Administração Pública. Coimbra: Livraria Almedina, 1996. p. 98-109. Ainda por esta obra, nota-se que há autores, dentre eles o administrativista Martins Claro, que identificam o princípio da imparcialidade com o princípio da legalidade: "a violação do princípio da imparcialidade não gera o desvio de poder mas a violação da lei" (nota de rodapé n. 211, p.104). Ou ainda, aqueles que o identificam com o princípio da finalidade, como se infere da observa da autora Maria Teresa, sobre o constitucionalista Jorge Miranda e, no sentido de que "para este autor, do princípio da imparcialidade decorre a obrigação de a Administração actuar com objetividade, isenção e independência face aos interesses privados com que se depara, na mais estrita prossecução do interesse público" (mesma obra, p. 108). David Duarte também discorre sobre o princípio de imparcialidade (DUARTE, David. Procedimentalização, Participação e Fundamentação: para uma concretização do princípio da imparcialidade administrativa como parâmetro decisório. Coimbra: Livraria Almedina, 1996. p. 258-465).

${ }^{151}$ A Constituição Portuguesa, no item 2, do art. 266, dispõe que "Os órgãos e agentes administrativos estão subordinados à Constituição e à lei e devem actuar, no exercício das suas funções, com respeito pelos princípios da igualdade, da proporcionalidade, da justiça e da imparcialidade" (RIBEIRO, Maria Teresa de Melo. O Princípio da Imparcialidade da Administração Pública. Coimbra: Livraria Almedina, 1996. p. 8687).

${ }^{152}$ Idem, ibidem. p. 155

${ }^{153}$ Idem, ibidem. p. 161.
} 
de mestrado no sentido de que "Ao mesmo tempo que se torna necessário assegurar a subordinação total da actividade administrativa ao Direito, acentua-se a necessidade de reforçar os vínculos de subordinação da Administração ao interesse público definido por lei: o princípio da imparcialidade afigura-se ser o meio mais adequado para alcançar esta dupla exigência vinculativa" ${ }^{\prime 154}$.

Partindo de trabalho de compilação de Jorge Miranda, Renata Porto de Adri Rosa ${ }^{155}$, conforme já observado, transcreve disposições constitucionais da Itália, Portugal e Espanhola, que, segundo ela, frise-se, a "influência é nítida em nosso sistema", para indicar que todas elas reconhecem o princípio da imparcialidade.

Assim, o art. 97 da Constituição Italiana dispõe que "Os serviços públicos organizam-se de acordo com a lei, de modo a assegurar-se o bom andamento e a imparcialidade de administração"; o art. 267, da Constituição Portuguesa estabelece que "1. A Administração Pública visa a prossecução do interesse público, no respeito pelos direitos e interesses legalmente protegidos dos cidadãos. 2. Os órgãos e agentes administrativos estão subordinados à Constituição e à lei e devem actuar com justiça e imparcialidade no exercício das suas funções"; e, por fim, que o art. 103, da Constituição Espanhola dispõe que “3. A lei regulará o estatuto dos funcionários, o acesso à função pública segundo os princípios de mérito e capacidade, o sistema de incompatibilidades e as garantias de imparcialidade no exercício das suas funções”.

\section{2. A impessoalidade mesclada: com concepções dúplices ou múltiplas}

Existem vários autores que concebem o princípio de impessoalidade como uma aglutinação, uma mescla, de vários outros princípios, ressaltando que o princípio teria distintos aspectos, mais de uma perspectiva ou enfoque.

\subsubsection{A impessoalidade como finalidade e imputação}

Maria Sylvia Zanella Di Pietro ${ }^{156}$ concebe o princípio, em síntese, sob dois enfoques: como equivalente ao princípio da finalidade e também correspondente à

\footnotetext{
154 RIBEIRO, Maria Teresa de Melo. O Princípio da Imparcialidade da Administração Pública. Coimbra: Livraria Almedina, 1996. p.. 340.

${ }^{155}$ ROSA, Renata Porto de Adri. Princípio de Impessoalidade. In et al - prefácio de Lúcia Valle Figueiredo. Princípios Informadores do Direito Administrativo. São Paulo: Editora NDJ, 1997. p. 35.

156 DI PIETRO, Maria Sylvia Zanella. Direito Administrativo. $25^{\mathrm{a}}$ ed. São Paulo: Atlas, 2012. p. 68. O mesmo entendimento já constava da $20^{\mathrm{a}}$ ed. da mesma obra, p. 62-63.
} 
ideia de que os atos praticados são imputados ao órgão ou entidade e não ao funcionário. Segundo sua compreensão, "Exigir impessoalidade da Administração tanto pode significar que este atributo deve ser observado em relação ao administrado como à própria Administração. No primeiro sentido, o princípio estaria relacionado com a finalidade pública que deve nortear toda a atividade administrativa. Significa que a Administração não pode atuar com vistas a prejudicar ou beneficiar pessoas determinadas, uma vez que é sempre o interesse público que tem de nortear o seu comportamento (...) No segundo sentido, o princípio significa, segundo José Afonso da Silva [...] baseado na lição de Gordillo que 'os atos e provimentos administrativos são imputáveis não ao funcionário que os pratica, mas ao órgão ou entidade administrativa da Administração Pública, de sorte que ele é o autor institucional do ato. Ele é apenas o órgão que formalmente manifesta a vontade estatal'. Acrescenta o autor que, em consequência, 'a realizações governamentais não são do funcionário ou autoridade, mas da entidade pública em nome de quem as produzira (...)"”.

Para a professora, o princípio está implicitamente no inc. III, parágrafo único, do art.2 $2^{\circ}$, da Lei n. 9.784/99, que exige "objetividade no atendimento do interesse público, vedada a promoção pessoa de agentes ou autoridades”. Esta mesma Lei, naquilo que diz respeito a impedimentos e suspeições (arts. 18 a 21), segundo a professora, também se inserem como aplicação do princípio.

$\mathrm{Na}$ linha da teoria de imputação, ela acrescenta que o princípio tem aplicação "em matéria de exercício de fato, quando se reconhece validade aos atos praticados por funcionários irregularmente investidos no cargo ou função, sob o fundamento de que os atos são do órgão e não do agente público".

\subsubsection{A impessoalidade como finalidade e imparcialidade}

Em nota de rodapé, em Princípios Constitucionais, Sérgio Sérvulo da Cunha $^{157}$ observa, fazendo menção a Hely Lopes Meirelles, que o princípio de impessoalidade "é o princípio, conhecido tradicionalmente, em Direito Administrativo, como 'princípio de finalidade". Para ele, "ela significa basicamente que o agente do

\footnotetext{
${ }^{157}$ CUNHA, Sérgio Sérvulo da. Princípios constitucionais. São Paulo: Saraiva, 2006. p. 152-153. Anote-se que o autor associa à impessoalidade a questão relacionada a grupos de interesses ou de pressão, a "lobbies", observando que, em relação a estes, "pior do que os abusos do 'lobbying' é sua clandestinidade, sua desigualdade e sua intimidade com o executivo, tanto mais acoroçoada quanto maior a predominância deste". Por fim, registra a existência de exceções de impessoalidade, dando como exemplo, a lei que reconhece o direito do réu de ficar calado e aquela que estabelece competência ratione personae.
} 
governo, no exercício de sua função, deve mover-se por padrões objetivos, e não por interesses ou inclinações particulares, próprias ou alheias. Contra o princípio da impessoalidade atentam, por exemplo, o oportunismo, o nepotismo, o partidarismo, que fazem passar os interesses pessoais á frente do interesse público”.

Em seguida, o autor afirma, contudo, que "Quando se trata de decidir sobre interesses de outrem, a busca da imparcialidade - não da frieza - é o principal propósito da impessoalidade".

\subsubsection{A impessoalidade como igualdade e legalidade}

Inocêncio Mártires Coelho ${ }^{158}$ entende o princípio como sendo corolário dos princípios de legalidade e de igualdade. Mais precisamente expõe que "Corolário do princípio maior da legalidade, que a rigor o absorve - a lei é expressão da vontade geral -, o princípio da impessoalidade consubstancia a ideia de que a Administração Pública, enquanto estrutura composta de órgãos e de pessoas incumbidas de gerir a coisa pública, tem de desempenhar esse múnus sem levar em conta interesses pessoais, próprios ou de terceiros, a não ser quando o atendimento de pretensões parciais constitua concretização do interesse geral. Afinal de contas, a otimização da ordem jurídica objetiva não raro se concretiza, precisamente, no respeito e na satisfação de pretensões subjetivas albergadas pelo ordenamento jurídico. O princípio da impessoalidade, por outro lado, convoca o da igualdade, na medida em que este último postulado impõe aos agentes públicos, em geral, e não apenas ao administrador, medir a todos com o mesmo metro".

\subsubsection{A impessoalidade como isonomia e finalidade}

José dos Santos Carvalho Filho ${ }^{159}$ compreende o princípio sob dois aspectos: como uma faceta do princípio da isonomia e com o princípio da finalidade. Observa que o "princípio objetiva a igualdade de tratamento que a Administração deve dispensar aos administrados que se encontrem em idêntica situação jurídica. Nesse ponto, representa uma faceta do princípio da isonomia. Por outro lado, para que haja verdadeira

\footnotetext{
${ }^{158}$ MENDES, Gilmar Ferreira; COELHO, Inocêncio Mártires; BRANCO, Paulo Gustavo Gonet. Curso de Direito Constitucional. $2^{\mathrm{a}}$ ed. revisada e atualizada. São Paulo: Saraiva, 2008. p. 833. Anote-se que coube a Inocêncio Mártires Coelho escrever sobre os princípios da Administração Pública, conforme explicado na parte intitulada Explicação e Dedicatória, p. V.

${ }^{159}$ AULETE, Caldas. Manual de Direito Administrativo. $25^{\mathrm{a}}$ ed. ampliada e atualizada até 03.01.2012. Rio de Janeiro: Lumen Juris, 2012. p. 20-21.
} 
impessoalidade, deve a Administração voltar-se exclusivamente para o interesse público, e não para o privado, vedando-se, em consequência, sejam favorecidos alguns indivíduos em detrimento de outros e prejudicados alguns para favorecimento de outros. Aqui reflete a aplicação do conhecido princípio da finalidade (...) segundo o qual o alvo a ser alcançado pela Administração é somente o interesse público, e não se alcança o interesse público se for perseguido o interesse particular, porquanto haverá nesse caso sempre uma atuação discriminatória".

Mais adiante, associando o princípio à ideia de "desvio de finalidade", este autor observa que "embora sob a expressão 'desvio de finalidade', o princípio de impessoalidade tem proteção no direito positivo: o art. 2º alínea 'e', da Lei n. 4.717/1965, que regula a ação popular, comina a sanção de invalidade o desvio de finalidade" 160 .

Pode-se incluir neste grupo o professor Diogo de Figueiredo Moreira Neto $^{161}$, que, a apesar de informar que o princípio "tem uma tríplice acepção", aponta, em essência, duas: algo como a isonomia e a finalidade. Mais precisamente, argumenta que na primeira acepção, o princípio "proíbe a Administração de distinguir interesses onde a lei não o fizer. Na segunda, proíbe a Administração de prosseguir interesses públicos secundários, dela próprios,desvinculados dos interesses públicos primários. Neste caso enfatiza a natureza jurídica ficta da personalização do Estado, que, por isso, jamais deverá atuar em seu exclusivo benefício, como pessoa instrumental, mas sempre o da sociedade. $\mathrm{Na}$ terceira acepção, proíbe com ligeira diferença sobre a segunda, que a Administração dê preferência a quaisquer interesses outros, em detrimento dos finalísticos, ou seja, os da sociedade, postos à sua cura".

Logo em seguida, ele afirma que "Como se pode observar, as três acepções confluem para definir a correta atuação do Estado enquanto administrador, relativamente à sua indisponível finalidade objetiva, que vem que vem a ser aquela expressa pela legislação, ou seja, totalmente despida de qualquer inclinação, tendência ou preferência subjetiva, mesmo em benefício próprio, condição que induziu Cirne Lima a afirmar que a boa administração é a que prima pela 'ausência de subjetividade"” (sic).

\footnotetext{
${ }^{160}$ AULETE, Caldas. Manual de Direito Administrativo. $25^{\mathrm{a}}$ ed. ampliada e atualizada até 03.01.2012. Rio de Janeiro: Lumen Juris, 2012.p. 21. A propósito, tal como redigido o parágrafo, tem-se a impressão que o princípio de impessoalidade necessita de proteção no ordenamento positivo; ou seja, como se o princípio constitucional necessitasse de garantia na legislação infraconstitucional para ter existência.

${ }^{161}$ MOREIRA NETO, Diogo de Figueiredo. Curso de Direito Administrativo: parte introdutória, parte geral e parte especial. Rio de Janeiro: Forense, 2009. p. 104.
} 
Para Rafael Carvalho Rezende Oliveira ${ }^{162}$, o princípio da impessoalidade "possui duas acepções possíveis: igualdade (ou isonomia) e proibição de promoção pessoal (...) Em relação ao primeiro sentido (...) A Administração deve dispensar tratamento impessoal e isonômico aos particulares, sendo vedada a discriminação odiosa ou desproporcional (...) Daí que se diz que o princípio da impessoalidade relacionar-se com a ideia de 'finalidade pública' (...) Quanto ao seguindo sentido (...) as realizações públicas não são feitos pessoais dos seus respectivos agentes, mas, sim, da respectiva entidade administrativa. Por essa razão, é vedado ao agente público utilizar a função pública para satisfazer os seus interesses pessoais. A atuação do agente público deve ser pautada pela efetivação do interesse público e deve ser imputada ao estado".

Em Notas sobre o princípio da impessoalidade e sua aplicação no direito brasileiro ${ }^{163}$, embora não tenha apresentado sua concepção sobre o princípio em questão, Dora Maria de Oliveira Ramos, após fazer menção a doutrinadores nacionais e estrangeiros e observar que este seu estudo "traz apenas uma breve provocação sobre o tema", conclui que estão "corretos os estudiosos que aproximam a impessoalidade dos princípios da igualdade e da finalidade".

\subsubsection{A impessoalidade como imparcialidade e objetividade}

Discorrendo sobre "a procedimentalização"164, Marçal Justen Filho ${ }^{165}$ não conceitua o princípio, mas, conforme se infere de sua argumentação, pode-se dizer que ele o relaciona à imparcialidade e à objetividade ao anotar que "a Constituição determina que a atividade administrativa deverá sujeitar-se não apenas ao principio da legalidade, mas também à impessoalidade e à moralidade (art. 37). Daí decorre que a decisão

162 OLIVEIRA, Rafael Carvalho Rezende. Princípios do Direito Administrativo. Rio de Janeiro: Lumen Juris, 2011. p. 95-97.

163 RAMOS, Dora Maria de Oliveira. Princípios de direito administrativo: legalidade, segurança jurídica, impessoalidade, publicidade, motivação, eficiência, moralidade, razoabilidade, interesse público. In MARRARA, Tiago (org.). ___. São Paulo: Atlas, 2012. p. 119-132.

164 JUSTEN FILHO, Marçal. Curso de Direito Administrativo. $8^{\mathrm{a}}$ ed. revista, ampliada e atualizada. Belo Horizonte: FORUM, 2012. p. 296. A título de registro, anote-se que o autor diz que a "procedimentalização consiste na submissão das atividades administrativas à observância de procedimentos como requisito de validade das ações e omissões adotadas. Significa que a função administrativa se materializa em atividade administrativa, que é o conjunto de atos. Esse conjunto de atos deve observar uma sequência predeterminada, que assegure a possibilidade de controle do poder jurídico para realizar os fins de interesse coletivo e a promoção dos direitos fundamentais (...) A procedimentalização impede a concentração decisória num ato imediato e único (...) Enfim, a procedimentalização exige que todo e qualquer decisão administrativa seja logicamente compatível com os eventos que lhe foram antecedentes e se traduza em manifestação fundada em motivos, cuja procedência é requisito de validade".

165 JUSTEN FILHO, Marçal. Curso de Direito Administrativo. $8^{\mathrm{a}}$ ed. revista, ampliada e atualizada. Belo Horizonte: FORUM, 2012. p. 330. 
administrativa deve considerar, segundo o postulado da ética, os interesses privados. Não são admissíveis decisões favoráveis ao Poder Público fundadas exclusivamente na titularidade do pode de decidir. Se o Estado impuser seus interesses, ignorando a incidência dos princípios jurídicos, estará atuando arbitrariamente. Ainda quando esteja em jogo um bem que interesse a ele próprio, o Estado terá de decidir de modo impessoal. Portanto, a disciplina do procedimento tem de assegurar a imparcialidade do julgador e consagrar o dever de aplicar o direito objetivamente ao caso concreto".

Em nota de rodapé na mesma página, este autor acrescenta que "reconhecer que o Estado é parte no litígio e que isso afasta sua imparcialidade não equivale a dispensar a observância do princípio da imparcialidade (derivado da objetividade e moralidade)".

Entretanto, discorrendo sobre os princípios norteadores da licitação ${ }^{166}$, o autor afirma que a "impessoalidade é a emanação da isonomia, da vinculação à lei e ao ato convocatório e da moralidade. Indica a vedação a distinções fundadas em caracteres pessoais dos interessados. Ao menos os caracteres pessoais devem refletir diferenças efetivas e concretas (que sejam relevantes para fins da licitação). Exclui o subjetivismo do agente administrativo. A decisão será impessoal quando derivar racionalmente de fatores alheios à vontade psicológica do julgador. A impessoalidade conduz a decisão a independer da identidade do julgador ${ }^{30}$. A 'vantajosidade' da proposta deve ser apurada segundo um julgamento objetivo. $\mathrm{O}$ ato convocatório tem de conter critérios objetivos de julgamento que não se fundem nas preferências ou escolhas dos julgadores. O julgamento das propostas subordina-se obrigatoriamente àqueles critérios".

Embora não conceitue o princípio, Demian Guedes ${ }^{167}$ observa que ele “favorece o entendimento de que o Poder Público deve, no processo administrativo restritivo de direitos, produzir prova dos pressupostos fáticos de seus atos".

\footnotetext{
166 JUSTEN FILHO, Marçal. Curso de Direito Administrativo. $8^{\mathrm{a}}$ ed. revista, ampliada e atualizada. Belo Horizonte: FORUM, 2012. p. 446. Anote-se que na nota de rodapé n. 30, o autor acrescenta que "Como afirmou o extraordinário M. SEARA FGUNDES, é '... da essência do processo licitatório, tessitura formal capaz de preservar a eleição dos co-contratantes de qualquer influência parcial dos agentes administrativos' (Licitação - formalidades - evitação da discricionariedade no julgamento, RDP, 78/78, abr./jun. 1986)".

${ }^{167}$ GUEDES, Demian. Processo Administrativo e democracia - prefácio de Leonardo Greco; apresentação de Marcos Juruena Villela Souto. Belo Horizonte: Fórum, 2007. pp. 128-133. Registre-se, porque relevante, que o autor havia afirmado antes que "Carlos Ari Sundfeld ressalta no processo administrativo sua função de garantir a observância do princípio da impessoalidade. Assim, a publicização e a processualização da atividade administrativa funcionam como instrumentos de maximização de sua racionalidade, possibilitando

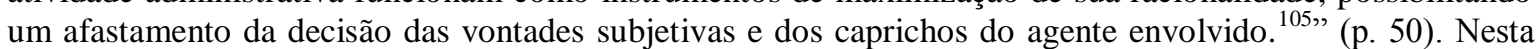
nota de rodapé n. 105, o autor cita Fundamentos de direito público, p. 93., daquele professor; contudo, não se confirmou tal afirmativa na edição na $4^{\mathrm{a}}$ edição, $7^{\mathrm{a}}$ tiragem, de 2006, na p. 93; entretanto, nela se lê, por exemplo, que "Não houvesse processo para a formação da vontade funcional, ela seria idêntica à vontade
} 
Acrescenta o autor, partindo da lição de Carlos Ari Sundfeld que os atributos da racionalidade, imparcialidade e equilíbrio "só são efetivamente garantidos pela prova no processo administrativo restritivo de direitos, libertando a Administração da subjetividade e do desequilíbrio provocados pela presunção de veracidade".

Adiante Demian Guedes registra que o exercício objetivo do poder "se aproxima da ideia de imparcialidade da Administração". E ao final, após citar outros autores, assevera que: "a partir dessas advertências doutrinárias, conclui-se que os princípios da impessoalidade e da imparcialidade concorrem também para a superação da presunção de veracidade no processo administrativo, impondo uma atuação objetiva do poder e tornando-o, assim, controlável".

\subsubsection{A impessoalidade como imputação e objetividade}

Discorrendo sobre a compreensão que vários doutrinadores têm sobre o princípio e após registrar que ele não se confunde com os princípios da igualdade e finalidade, Marcelo Harger ${ }^{168}$, sem apresentar de modo explícito seu conceito do princípio, dá a entender que ele possui as características de imputação e objetividade. É, pois, o que se infere de sua argumentação: “O fato de a figura da Administração Pública ser distinta da figura dos agentes que a representam não é de se estranhar. É, aliás, um fato que ocorre com todas as pessoas jurídicas, que não se confundem com a figura de seus sócios ou prepostos. Parece, diante disso, improvável que o constituinte tenha mencionado a impessoalidade com o objetivo de ressaltar unicamente essa característica. O princípio da impessoalidade compreende essa característica, mas a ela não se limita. Vai além”.

Adiante, ele afirma que a "impessoalidade refere-se ao agir do administrador. Este, como gestor da coisa pública, age em nome de terceiros, com o caráter funcional já referido. Por essa razão, não pode atuar impelido por critérios próprios e subjetivos, mas sim, segundo regras objetivas e controláveis racionalmente ${ }^{145}$. É que, enquanto o particular age em consonância com interesse pessoais, o agente público age em

livre: centrada no agente. O processo infunde ao ato racionalidade, imparcialidade, equilíbrio; evita que o agente o transforme em expressão de sua personalidade. Sem ele, o agente fatalmente excederia seu papel de intermediário entre o Direito (a Constituição, a lei) e o ato a ser produzido." (pp. 93-94).

${ }^{168}$ HARGER, Marcelo. Princípios Constitucionais do Processo Administrativo. $2^{\mathrm{a}}$ ed. revista e atualizada. Rio de Janeiro: Forense, 2008. p. 112-117. Anote-se que em suas notas de rodapé - n. 145 e 146 - o autor faz menção a Princípios Constitucionais do Processo Administrativo Disciplinar, de Romeu Felipe Bacellar Filho, p. 177. 
nome da coletividade, curando bens indisponíveis, e a ninguém é lítico ser desprendido com o que não lhe pertence ${ }^{146}$.

É por isso que o móvel do agente deve ser impessoal e objetivo".

Mais adiante, o autor declara que a "impessoalidade determina que o administrador atue com objetividade no curso do processo administrativo".

4.2.7. A impessoalidade como moralidade, publicidade, finalidade e imparcialidade

Para Odete Medauar ${ }^{169}$ o princípio de impessoalidade de algum modo parece se confundir com os princípios de moralidade e de publicidade. Argumentando que o princípio em questão recebe várias interpretações na doutrina, ela anota que "Os princípios da impessoalidade, moralidade e publicidade apresentam-se intrincados de maneira profunda, havendo, mesmo, instrumentalização recíproca; assim a impessoalidade configura-se meio para atuações dentro da moralidade; a publicidade, por sua vez, dificulta medidas contrárias à moralidade e impessoalidade; a moralidade administrativa, de seu lado implica observância da impessoalidade e da publicidade. Embora nem sempre seja possível afastar as implicações recíprocas desses princípios, o estudo em separado atende a requisitos didáticos".

Mais enfaticamente, a professora Odete Medauar assevera que com este princípio "a Constituição visa obstaculizar atuações geradas por antipatias, simpatias, objetivos de vingança, represálias, nepotismo, favorecimentos diversos, muito comuns em licitações, concursos públicos, exercício do poder de polícia. Busca-se, desse modo, que predomine o sentido de função, isto é, a ideia de que os poderes atribuídos finalizam-se ao interesse de toda a coletividade, portanto a resultados desconectados de razões pessoais. Em situações que dizem respeito a interesses coletivos ou difusos, a impessoalidade significa a exigência de ponderação equilibrada de todos os interesses envolvidos, para que não se editem decisões movidas por preconceitos ou radicalismos de qualquer tipo".

\footnotetext{
${ }^{169}$ MEDAUAR, Odete. Direito Administrativo Moderno. $15^{\mathrm{a}}$ ed, revista atualizada e ampliada. São Paulo: Revista dos Tribunais, 2011. p. 132-133. Anote-se, entretanto, que Fábio Medina Osório (OSÓRIO, Fábio Medina. Teoria da improbidade administrativa: má gestão pública; corrupção; ineficiência - prefácio de Eduardo Garcia de Enterría. $3^{a}$ ed.São Paulo: Editora Revista dos Tribunais, 2013. p. 133), fazendo menção ao livro $O$ direito administrativo em evolução. (MEDAUAR, Odete. São Paulo: Ed. RT, 1992) observa que Odete Medauar "afirma que, em um primeiro momento, entende-se por impessoalidade administrativa o princípio segundo o qual a Administração Pública atua representada por seus agentes, situando-se estes como longa manus. Não atuam os agentes em nome próprio, mas, impessoalmente, na representação dos interesses públicos da Administração Pública. Com certeza, porque não representam, ou não poderiam representar, seus próprios interesses, os agentes públicos devem atuar de modo impessoal e imparcial”.
} 
Entretanto, acrescente-se que em $O$ direito administrativo em evolução ${ }^{170}$, a autora parece associá-lo ao princípio da imparcialidade. Discorrendo sobre a noção de interesse público e a necessidade de ponderação dos interesses em confronto, ela argumenta que "Pode-se associar a orientação ora exposta, de necessidade de completa apreciação de todos os fatores e interesses, com vista à sua conciliação e sacrifício mínimo, à previsão do princípio de impessoalidade, para todos os setores da Administração pública, na Constituição federal, art. 37, caput. ${ }^{23}$ ". E, em nota de rodapé n. 23 , registra que "É o sentido conferido por Allegretti ao princípio da imparcialidade que a Constituição italiana de 1947 prevê para a Administração pública (cf. L’imparcialità amministrativa, Pádua, 1965, p. 28). A Constituição espanhola de 1978 utiliza o termo objetividade, no art. 103, item 1: A Administração pública serve como objetividade os interesses gerais”.

É interessante registrar que no livro A processualidade no Direito Administrativo a professora é mais incisiva e traz outras considerações.

Mais precisamente, no subtítulo Processo administrativo $e$ impessoalidade, ela se manifesta nos seguintes termos: "Impessoalidade, imparcialidade, objetividade envolvem tanto a ideia de funcionários que atuem em nome do órgão, não para atender objetivos pessoais, como de igualdade dos administrados e atuação norteada por fins de interesse público. Trata-se de ângulos diversos do intuito essencial de impedir que fatores pessoais, subjetivos, sejam os verdadeiros móveis e fins das decisões administrativas. Com o princípio de impessoalidade, a Constituição visa a obstaculizar atuações por antipatias, simpatias, objetivos de vingança, represálias, trocos, nepotismo, favorecimentos diversos, muitos comuns em concursos públicos, licitações, processo disciplinares, exercício do poder de polícia. Busca, desse modo, fazer predominar o sentido de função, isto é, o caráter objetivo nas atuações dos agentes, pois, sob tal enfoque, os poderes atribuídos não se destinam a atender interesses móveis subjetivos e pessoais; finalizam-se ao interesse de toda a coletividade, portanto a resultados desconectados de razões pessoais. Em situações que dizem respeito a interesses coletivos ou difusos, a impessoalidade significa a exigência de ponderação equilibrada de todos os interesses envolvidos, para evitar decisões movidas por preconceitos e radicalismos ideológicos ou pela busca de benesses de tipo diversos.

Nessa ordem de considerações, o processo administrativo representa instrumento de objetividade do poder, para evitar ou dificultar que motivos e fins

${ }^{170}$ MEDAUAR, Odete. O direito administrativo em evolução. São Paulo: Editora Revista dos Tribunais, 1992. p. 183. 
subjetivos informem a tomada de decisões, pois nele se contrapõem argumentos, dados e fatos, que permanecem registrados; se móveis subjetivos, mesmo assim, afetarem a decisão, torna-se mais fácil o controle administrativo e jurisdicional"171.

\subsubsection{A impessoalidade como isonomia, finalidade e imputação}

Fernanda Marinela ${ }^{172}$, mencionando José dos Santos Carvalho Filho, ensina num primeiro momento que o princípio "estabelece que a atuação do agente público deve basear-se na ausência de subjetividade, ficando esse impedido de considerar quaisquer inclinações e interesses pessoais, próprios ou de terceiros. A impessoalidade objetiva a igualdade de tratamento que a Administração deve aplicar aos administrados que se encontrarem em idêntica situação jurídica, representando, nesse aspecto, uma faceta da isonomia". Logo em seguida, contudo, acrescenta que o princípio "também pode ser analisado sob dois aspectos diferentes: primeiro, quando ao dever de atendimento ao interesse público, tendo o administrador a obrigação de agir de forma impessoal, abstrata, genérica, protegendo sempre a coletividade; segundo, que a atividade administrativa exercida por um agente público seja imputada ao órgão ou entidade e não ao próprio agente (...) pois a vontade do agente se confunde com a da pessoa jurídica, formando uma única vontade, o que se conclui na chamada teoria da imputação".

Ao final, citando decisão do STF, esta professora acrescenta que "o dever de agir de forma impessoal também se configura hoje previsão do at. $37, \S 1^{\circ}$, do texto constitucional que estabelece o dever de publicidade dos atos e programas dos órgãos públicos de forma desvinculada da pessoa dos administradores públicos, impedindo que constem nomes, símbolos ou imagens que representem promoção pessoal de qualquer autoridade pública, tendo como objetivo o caráter educativo e orientação social".

Neste sentido também parece ser a compreensão que Alexandre Santos Aragão ${ }^{173}$ tem do princípio. O autor inicia sua argumentação afirmando que "mencionado expressamente no art. 37, caput, da Constituição da República, o princípio da

\footnotetext{
${ }^{171}$ MEDAUAR, Odete. A processualidade no direito administrativo. $2^{\text {a }}$ ed. revista, atualizada e ampliada. São Paulo: Editora Revista dos Tribunais, 2008. p. 93.

${ }^{172}$ MARINELA, Fernanda. Direito Administrativo. $7^{\text {a }}$ ed. Niterói: Impetus, 2013. p. 34. A autora faz menção ao RE 191.668/RS - STF - Primeira Turma, Rel. Min. Menezes de Direito, julgamento: 15.04.2008, DJ: 30.05.2008. A título de registro, parte deste acórdão registra que “(...) O rigor do dispositivo constitucional que assegura o princípio da impessoalidade vincula a publicidade ao caráter educativo, informativo ou de orientação social é incompatível com a menção de nomes, símbolos ou imagens, aí incluídos slogans, que caracterizem promoção pessoal ou de servidores públicos (...)”.

${ }^{173}$ ARAGÃO, Alexandre Santos. Curso de Direito Administrativo. Rio de Janeiro: Forense, 2012. p. 70-71.
} 
impessoalidade, que não deixa de ser uma especialização do princípio da igualdade no Direito Administrativo, costuma incidir de forma simultânea com os princípios da moralidade e da finalidade, havendo um fortalecimento recíproco".

Logo adiante, ele conclui que "Há duas acepções para o princípio da impessoalidade, ambas igualmente corretas, apenas destacando ângulos diversos de um mesmo fenômeno.

Em primeiro lugar pode se considerar a impessoalidade à luz da organização administrativa; ela impõe que os atos da Administração Pública sejam imputados ao Estado, não ao agente/pessoa física que o praticou. O princípio da impessoalidade nessa linha seria fundamento da Teoria dos Órgãos (...) e, indiretamente da responsabilidade civil do estado por atos praticados por seus agentes.

Já Hely Lopes Meirelles vincula a impessoalidade pública, entendendo que o princípio da impessoalidade impõe que o administrador objetive, apenas, a satisfação do interesse público, jamais a obtenção de benefícios pessoais, para si ou para terceiros, ou os prejuízos de quem quer que seja (ex.: a perseguição de um inimigo político). A impessoalidade tem sido usada, na jurisprudência, para impedir a atribuição de cunho pessoal a ações estatais (art. 37, §1, $\mathrm{CF}$ ); para proibir que recursos públicos sejam instrumentalizados por interesses privados; para vedar a nomeação para cargos de confiança por afinidade pessoal ou familiar etc.

Repetimos, no entanto, que, em todos esses casos, há uma multiviolação de princípios do Direito Administrativos, porque, por exemplo, uma viagem privada paga pelo erário é, ao mesmo tempo, uma violação à finalidade de interesse público (Princípio da Finalidade), uma atuação imoral (Princípio da Moralidade), um desperdício de dinheiro público (Princípio da Eficiência e da Economicidade) e uma instrumentalização da coisa pública para interesses pessoais do agente público beneficiado (Princípio da Impessoalidade)".

Flávia Cristina Moura de Andrade ${ }^{174}$, citando a Resolução do CNJ n. 07/2005 (atualizada pelas Resoluções n. 9/2005 e n. 21/2006), afirma que o princípio de impessoalidade "impõe tratamento igualitário aos administrados, bem como nos remete à ideia de que os agentes públicos devem ter uma atuação neutra".

Especificamente sobre esta "atuação neutra", ela exemplifica que "se um auditor público lavra um auto de infração contra uma empresa, na verdade quem o fez foi o

\footnotetext{
${ }^{174}$ ANDRADE, Flávia Cristina Moura de. Direito Administrativo. 2ª ed.São Paulo: Premier Máxima, 2008.
} p. 37-39. (Coleção Elementos do Direito). 
poder público, e outro auditor poderá rever ou manter a cobrança; nas divulgações de realizações de obras públicas não deve constar o nome do Prefeito mas, sim, é necessário fazer menção à Administração Municipal”.

Ao discorrer sobre o princípio de finalidade, contudo, ela, após dar um exemplo, conclui que este princípio "é uma espécie da impessoalidade (...) (igualdade de tratamento aos administrados)".

Esta compreensão do princípio parece ser também a de Emerson Garcia e Rogério Pacheco Alves ${ }^{175}$, que, embora iniciem a exposição no sentido de que o princípio deve ser concebido em dupla perspectiva, ao final acrescentam o princípio da finalidade. Em síntese, argumentam da seguinte forma: "Esse princípio deve ser concebido em uma dupla perspectiva. Em um primeiro sentido, estatui que autor dos atos estatais é o órgão ou a entidade, e não a pessoa do agente (acepção ativa).

Sob outra ótica, torna cogente que a administração dispense igualdade de tratamento a todos aqueles que se encontrem em posição similar, o que pressupõe que os atos praticados gerem os mesmos efeitos e atinjam a todos os administrados que estejam em idêntica situação fática ou jurídica, caracterizando a imparcialidade do agente público".

Logo em seguida, acrescentam que "preserva-se o princípio da isonomia entre os administrados e o princípio da finalidade, segundo o qual a atividade estatal deve ter sempre por objetivo a satisfação do interesse público, sendo vedada a atividade discriminatória que busque unicamente a implementação de um interesse particular".

Embora à primeira vista fosse possível incluir Uadi Lammêgo Bulos ${ }^{176}$ entre aqueles que concebem o princípio como o princípio de finalidade, na verdade, este autor parece compreender o princípio como relacionado à noção de finalidade, igualdade $\mathrm{e}$ imputação. É, pois, o que se nota de sua argumentação: “O princípio de impessoalidade, consectário natural do princípio de finalidade, impõe que o ato administrativo seja praticado de acordo com os escopos da lei, precisamente para evitar a autopromoção de agentes públicos (...) A impessoalidade, visa, pois, coibir o desvio de finalidade de ato comissivo ou omissivo na Administração Pública, impedindo que o administrador pratique ação ou omissão para beneficiar a si próprio ou a terceiros. O vetor da impessoalidade recai, também, sobre a figura do administrado.

175 GARCIA, Emerson; ALVES, Rogério Pacheco. Improbidade administrativa. $2^{\mathrm{a}}$ ed. revista e ampliada. Rio de Janeiro: Lumen Juris, 2004. p. 55-56.

${ }^{176}$ BULOS, Uadi Lammêgo. Curso de Direito Constitucional. $2^{\text {a }}$ ed. revista e atualizada de acordo com a Emenda Constitucional n. 56/2007. São Paulo: Saraiva, 2008. p. 802-803. 
Assim os atos e provimentos administrativos não são imputados unicamente aos órgãos ou entidades administrativas em nome dos quais os agentes públicos agem. Imputam-se, também, aos administrados, que devem ser tratados sem discriminação nem favoritismos.

Nesse aspecto, a impessoalidade constitui um desdobramento do pórtico geral da igualdade (art. $5^{\circ}$, caput) (...)”.

\subsubsection{A impessoalidade como igualdade, finalidade e imparcialidade}

Embora Cármen Lúcia Antunes Rocha ${ }^{177}$ tenha sustentado a distinção entre os princípios de impessoalidade, de igualdade e de finalidade (como se aquele fosse uma especificidade daqueles), percebe-se, na verdade, que, ao assumir esta empreitada, ela acaba por admitir implicitamente que estes dois últimos princípios são as faces do princípio de impessoalidade, o que a faz ser incluída entre aqueles que concebem o princípio como relacionado à finalidade, à igualdade e à imparcialidade.

Diz esta professora que o "princípio constitucional da impessoalidade administrativa tem como objeto a neutralidade da atividade administrativa, fixando como única diretriz jurídica válida para os comportamentos estatais o interesse público.

A impessoalidade no trato da coisa pública garante exatamente esta qualidade da res gerida pelo Estado: a sua condição de ser pública, de todos, patrimônio de todos voltados à concretização do bem de todos e não de grupos ou de algumas pessoas.

À generalidade da lei corresponde a impessoalidade da administração, e é isto o que garante a resistência contra usos e abusos do Poder do Estado por pessoas ou grupos" ${ }^{178}$.

Mais adiante, ao pretender sustentar a distinção de impessoalidade e igualdade, a autora, hoje Ministra do Supremo tribunal Federal, anota que o "princípio da igualdade objetiva não discriminar, não distinguir onde razões de Justiça concebidas e acatadas pela ordem de Direito não existam (...)

\footnotetext{
${ }^{177}$ ROCHA, Cármen Lúcia Antunes. Princípios constitucionais da administração pública. , Belo Horizonte: Del Rey, 1994. p. 145-171. A propósito, na empreitada de distinguir o princípio de impessoalidade dos princípios de igualdade e de finalidade, a autora parece se contradizer: num primeiro momento argumentou que "A impessoalidade administrativa é direito do cidadão e é dever do Estado" (p. 151); mais adiante, ponderou que "A igualdade é direito e o seu titular é o indivíduo ou o cidadão. A impessoalidade é dever e quem o titulariza é a Administração pública" (p. 154).

${ }^{178}$ Idem, ibidem. p. 147.
} 
O princípio da impessoalidade administrativa objetiva, basicamente, não permitir que o administrador se privilegie, pois deste privilégio do agente público nasce o prejuízo de toda a sociedade. (...)

Vê-se, pois, que ambos são princípios de observância obrigatória da Administração Pública, mas o da impessoalidade o é em caráter exclusivo, vale dizer, não desborda da esfera estatal, tendo aí o seu espaço de incidência.

$\mathrm{Na}$ verdade, estes dois princípios recobrem realidades diferentes, sendo o conteúdo da igualdade jurídica mais amplo e dotado de primariedade que se desdobra (...) dentre outros, no princípio da impessoalidade administrativa. (...)

$\mathrm{O}$ realce dado pela igualdade jurídica é, pois, quanto à ausência de discriminações fundadas em preconceitos ou conceitos subjetivos sobre as pessoas (...)

$\mathrm{Na}$ impessoalidade, a ênfase está na ausência de subjetividade e voluntarismo do administrador público, para que ele exerça a sua função com vistas ao interesse de todo o povo, voltando-se à finalidade pública" ${ }^{\prime 79}$.

Acrescente, por fim, que em certa oportunidade, a professora mineira, sugere a ligação do princípio com o da imparcialidade. É pois, o que se observa desta passagem com uma nota de rodapé ao final: "Neste caso, aliás, é de alta significação o princípio da impessoalidade administrativa, para assegurar não apenas que pessoas não recebam tratamento particularizado em razão de suas condições específicas (privilegiadoras ou prejudiciais), mas ainda para vedar a adoção de comportamento administrativo motivado pelo partidarismo.

É o princípio da impessoalidade que, tomado com um significado mais amplo, assegura que as vinculações partidárias das pessoas que chegam aos cargos do Poder público, deles não se valham para realizarem-se interesses partidários do grupo ou facção que domine os cargos diretivos da Administração Pública"”.

Nesta nota de rodapé n. 3, a autora é mais expressiva: “O princípio da imparcialidade, referido em algumas Constituições como antes mencionado, e que guarda estreita vinculação com o que caracteriza o conteúdo deste, surgiu, aliás, no século passado, na Inglaterra, como uma necessidade de se impor neutralidade política à Administração Pública, entronizando-se, no final do século XIX, nos Estados Unidos (cf. GIANNINI, Massimo Severo,. Op. Cit. V.1, p.86).

\footnotetext{
${ }^{179}$ ROCHA, Cármen Lúcia Antunes. Princípios constitucionais da administração pública. , Belo Horizonte: Del Rey, 1994. p. 153.
} 
4.2.10. A impessoalidade como isonomia, imputação e objetividade

O princípio de impessoalidade, na lição de Dirley da Cunha Júnior ${ }^{180}$, "exige que a atividade administrativa seja exercida de modo a atender a todos os administrados, ou seja, a coletividade, e não a certos membros em detrimento de outros, devendo apresentar-se, portanto, de forma impessoal. Em razão deste princípio, a Administração deve manter-se numa posição de neutralidade em relação aos administrados, não podendo discriminá-los, salvo quando assim justificar o interesse coletivo, sob pena de cometimento de abuso de poder e desvio de finalidade (...) este princípio também significa que os atos e provimentos administrativos são imputáveis, não ao agente que os pratica, mas sim ao órgão ou entidade da Administração Pública, em nome dos quais o agente atua".

Acrescenta o autor que este princípio "aparece implicitamente no art. 20, parágrafo único, III, da lei 9.784/99, segundo o qual, nos processos administrativo serão observados os critérios de 'objetividade no atendimento do interesse público, vedada a promoção pessoal de agentes e autoridades”.

\subsubsection{A impessoalidade como neutralidade, finalidade e legalidade}

Evelise Pedroso Teixeira Prado Vieira ${ }^{181}$ informa que o princípio de impessoalidade "determina que o atuar administrativo há de ser neutro, no sentido de que não pode visar a beneficiar ou a prejudicar qualquer pessoa ou grupo de pessoas. O agente público deve buscar, sempre, a concreção do fim previsto em lei, não podendo dele se desviar, sob pena de o ato ser nulo por desvio de finalidade ou desvio de poder".

Entretanto, logo em seguida, a autora completa, observando que no Brasil o conceito de cidadania "não foi completamente apropriado pela coletividade", que "há de se ressaltar a importância da construção do princípio da impessoalidade de forma autônoma, muito embora pudesse ele ser compreendido com implícito no princípio de legalidade".

${ }^{180}$ CUNHA JÚNIOR, Dirley da. Curso de Direito Administrativo. $12^{\mathrm{a}}$ ed. revista, ampliada e atualizada. Bahia: JusPODIVM, 2013. p. 41.

${ }^{181}$ VIEIRA, Evelise Pedroso Teixeira Prado. Direito Administrativo. São Paulo: Verbatim, 2011. p. 61-62. 
4.2.12. A impessoalidade como imparcialidade, finalidade e imputação

\begin{abstract}
Alexandre Mazza ${ }^{182}$, fazendo menção a Hely Lopes Meirelles e a Lúcia Valle Figueiredo, ressaltando que "o dever de impessoalidade não se confunde com o princípio da isonomia", concebe o princípio em três aspectos. "O princípio da impessoalidade estabelece um dever de imparcialidade na defesa de interesse público, impedindo discriminações e privilégios indevidamente dispensados a particulares no exercício da função administrativa (...) A relação da impessoalidade com noção de finalidade é indiscutível (...) Ao agir visando a finalidade pública prevista na lei, a Administração Pública necessariamente imprime impessoalidade e objetividade na atuação, evitando tomar decisões baseadas em preferência pessoal ou sentimento de perseguição".
\end{abstract}

$\mathrm{Na}$ sequência, o autor conclui, acrescentando um outro aspecto ao princípio: “A impessoalidade possui outro aspecto importante. A atuação dos agentes públicos é imputada ao Estado, significando um agir impessoal da Administração Pública. Assim, as relações não devem ser atribuídas à pessoa física do agente público, mas à pessoa jurídica estatal a que estiver ligado".

${ }^{182}$ MAZZA, Alexandre. Manual de Direito Administrativo. $3^{\circ}$ ed. São Paulo: Saraiva, 2013. p. 92-93. 


\section{$\mathrm{V}$ - CONSIDERAÇÕES SOBRE DOIS TERMOS: IMPESSOAL E IMPESSOALIDADE}

Este trabalho parte da premissa de que a indeterminação - que não revela um mínimo de consenso - do conceito jurídico do princípio de impessoalidade reside também na abordagem semântica do termo impessoal ${ }^{183}$.

A propósito, por exemplo, nota-se que ao discorrer sobre o princípio, José dos Santos Carvalho Filho começa da definição do termo impessoal obtida do dicionário Caldas Aulete ${ }^{184}$. Isso se dá também com Lúcia Valle Figueiredo ${ }^{185}$, que parte da definição do verbete dos dicionários Lalande e Aurélio Buarque de Holanda.

É bem verdade que não se cogitaria exigir dos léxicos a conceituação do termo jurídico em questão, mas não se pode afastar a hipótese de que tenham de algum modo contribuído para a falta de um mínimo de consenso sobre este princípio constitucional. É, pois, por exemplo, quando se nota que algumas interpretações têm como substrato a noção de não privilegiar gostos, opiniões ou interesses pessoais, ou ainda de objetividade e imparcialidade como se isso fosse da "essência" do princípio, o próprio princípio.

Como se sabe, a semântica ${ }^{186}$ sozinha não é suficiente ${ }^{187}$ para conformar um conceito ${ }^{188}$, e.g., um conceito jurídico ${ }^{189}$. A etimologia ${ }^{190}$ também, por si só, não tem esta capacidade. Ambas, contudo, servem de ponto de partida.

\footnotetext{
${ }^{183}$ Alguns léxicos nacionais, v.g., parecem inspirar a confusão: I. o GRANDE DICIONÁRIO SACCONI DA LÍNGUA PORTUGUESA. comentado, crítico e enciclopédico. São Paulo: Nova Geração, 2010, registra o verbete IMPESSOAL como: que não é pessoal; que não se destina ou se refere a uma pessoa em particular; que não privilegia gostos, opiniões ou interesses pessoais; que não tem nenhum caráter pessoal, imparcial, objetivo; que não tem personalidade ou características humanas; que revela distanciamento ou frieza, distante, indiferente; II - o DICIONÁRIO HOUAISS DA LÍNGUA PORTUGUESA.Rio de janeiro: Objetiva, 2009, registra o verbete como o que não existe como pessoa, que não possui os atributos de pessoa; que não pertence ou não se refere a uma pessoa em particular; desprovido de qualquer traço pessoal com vistas a uma maior objetividade e imparcialidade; que não reflete qualquer particularidade individual, anônimo; e III - o NOVO AURÉLIO SÉCULO XXI: o dicionário da língua portuguesa. $3^{\mathrm{a}}$ edição totalmente revista e ampliada. Rio de Janeiro: Nova Fronteira, 1999 aponta o termo como o que no se refere ou não se dirige a uma pessoa em particular, mas às pessoas em geral; independente de, ou sobranceiro a qualquer circunstância ou particularidade; pouco original, incaracterístico.

${ }^{184}$ CARVALHO FILHO, José dos Santos. Manual de Direito Administrativo. $25^{\mathrm{a}}$ ed. ampliada e atualizada até 03.01.2012. Rio de Janeiro: Lumen Juris, 2012. p. 20. "Impessoal é 'o que não pertence a uma pessoa em especial', ou seja, aquilo que não pode ser voltado especialmente a determinadas pessoas".

${ }^{185}$ FIGUEIREDO, Lúcia Valle. Curso de direito administrativo. $8^{\text {a }}$ ed. revista, ampliada e atualizada até a emenda Constitucional 52/2006. São Paulo: Malheiros, 2006. p. 63-64.

186 "Se fizermos abstração do usuário da linguagem e analisarmos apenas as expressões e o que designam, estaremos no campo da semântica" (CARNAP, Rudolf. Fundamentos da lógica e da matemática apud MARCONDES, Danilo. A pragmática na filosofia contemporânea. Rio de Janeiro: Jorge Zahar Ed., 2005. p. 50).
} 
${ }^{187}$ A questão não é nova em Direito Administrativo. Garrido Falla, anota que quando se aborda a tarefa de definir a ideia de administrar, a doutrina tem recorrido com frequência à investigação da etimologia do vocábulo, observando que Giannini realçou, contudo, o auxílio limitado que é o de se socorrer da etimologia do termo, como é frequente na doutrina. (FALLA, Garrido. Tratado de Derecho Administrativo. Vol. 1, Parte Geral. $15^{\mathrm{a}}$ ed. Madrid: Editorial Tecnos, 2010. p. 35). Aqui no Brasil, por exemplo, J. Cretella Júnior, ao discorrer sobre pessoas jurídicas administrativas, mais especificamente sobre autarquia, anota que se acham "definitivamente incorporados ao léxico da língua portuguesa os vocábulos autarcia e autarquia, significando, respectivamente, entre nós, 'quantidade do que se basta a si mesmo' e 'autonomia', 'governo autônomo'. Não obstante ser vocábulo pouco feliz, incorporou-se a palavra autarquia, para sempre, à língua jurídica, significando, na acepção etimológica, atribuição de governar-se, mas, de modo mais preciso, 'administrar-se' com relativa independência e não de maneira absoluta, visto que a fiscalização superior do poder central é condição de toda descentralização administrativa que, em substância, é autarquia. A propósito disso, esclarece Bielsa, observamos que se pretendeu dar maior extensão à autarquia do que à autonomia. $\mathrm{O}$ erro provém de tomar o conceito em seu significado primitivo e etimológico".

${ }^{188}$ Sob o título de "Dificuldade conceitual", do capítulo intitulado Definição do Direito Administrativo (CRETElla JÚNIOR, J. Curso de Direito Administrativo de acordo com a Constituição de 1998. $11^{\mathrm{a}} \mathrm{ed}$. revista e atualizada, Rio de Janeiro: Forense, 1991. p. 19-20), José Cretella Júnior ensina que o "problema da definição não compete às disciplinas particulares. Definir é tarefa que incumbe à filosofia, no setor reservado à lógica dos conceitos, mas os próprios especialistas ressaltam a dificuldade que entra o espírito humano ao pretender resumir numa única proposição as notas características do objeto definido, correndo-se o risco ou de ficar-se aquém do objeto, ou além do objeto, abrangendo-se menos do que se quer ou mais do que se tem em mira. $\mathrm{O}$ direito administrativo não foge a estas observações de natureza genérica, do que resulta a multiplicidade de conceitos formulados pelos mais diferentes autores nestes últimos cem anos. Num ponto, entretanto, todos os autores estão de acordo: é que a definição deverá apoiar-se num CRITÉRIO, referencial obrigatório para a estrutura conceitual". Já com o título "Critérios adotados", o autor acrescenta que o "exame das distinções propostas pelos mais eminentes autores da literatura administrativa internacional revela, à primeira análise, o ponto de partida da síntese conceitual ora resultante do relevo, maior ou menor, que se atribui a este ou àquele traço do mundo administrativo, ora da posição filosófica ou tratadista diante dos fenômenos considerados, ora o escopo que julgam a matéria dever perseguir, ora o aspecto formal com que se apresenta a disciplina ao investigador, outras vezes ainda a dois ou mais elementos conjugados, tidos como fundamentais por quem se proponha a enfrentar o perigoso problema do definir. Desse modo, variam extremamente as colocações dos autores que, levados por critérios diferentes, atingem, é claro, conceitos também os mais diversos. A própria situação dos primeiros mestres do direito administrativo diante do caos em que se encontravam os textos legais serviu para imprimir-lhes uma natural e prática orientação, base rudimentar, mas necessária, para um primeiro ensaio de definição, mais tarde índice seguro de reconhecimento da escola denominada legalista, exegética, empírica ou caótica". No Dicionário de Filosofia, Nicola Abbagnano (ABBAGNANO, Nicola. Dicionário de Filosofia. Alfredo Bosi (Trad. e rev. da $1^{\mathrm{a}}$ ed. Brás. Ivone Castilho Benedetti (revisão da tradução e tradução dos novos textos). $6^{a}$ ed. São Paulo: WFM Martins Fontes, 2012), o verbete CONCEITO significa "Em geral, todo o processo que possibilite a descrição, a classificação e a previsão dos objetos cognoscíveis. (...) A noção de C. dá origem a dois problemas fundamentais: um sobre a natureza do C. e outro sobre a função do C (...) A) o problema da natureza do C. recebeu duas soluções fundamentais: $1^{a}$ o C. é a essência das coisas, mais precisamente a sua essência necessária, pela qual não podem ser de modo diferente daquilo que são; $2^{\mathrm{a}} \mathrm{o} \mathrm{C}$. é um signo. $1^{\mathrm{a}} \mathrm{A}$ concepção do C. como essência pertence ao período clássico da filosofia grega, em que o C. é assumido como o que se subtrai à diversidade e à mudança de pontos de vista ou de opiniões, porque se refere às características que, sendo constitutivas do próprio objeto, não são alteradas pela mudança de perspectiva (...) $2^{\mathrm{a}}$. Na segunda interpretação, o C. é um signo do objeto (qualquer que seja) e se acha em relação de significação com ele. (...) Deve-se notar, contudo, que o termo C. ou significado refere-se com mais frequência a conotação do que a denotação. Assim, Carnap, nas últimas obras, entendeu por C. a propriedade, o atributo ou função (Introduction to Semantics, 1942; $2^{\mathrm{a}}$ ed., 1959, §7) (...) B) A função C. pode ser concebida de duas maneiras fundamentais diferentes: como final e como instrumental. Função final é atribuída ao C. pela sua interpretação como essência, visto que, por essa interpretação, o C. não tem outra função senão exprimir ou revelar a substância das coisas. Desse ponto de vista, a função identifica-se com a própria natureza do conceito. Quando, porém, se admite a teoria simbólica do C., admite-se ipso facto também a sua instrumentalidade; e essa instrumentalidade pode ser aclarada e descrita nos seus múltiplos aspectos. Os aspectos principais são os seguintes: $1^{\circ}$ A primeira função atribuída a conceito é a de descrever os objetos da experiência para permitir o seu reconhecimento (...) Essa função descritiva ou recognitiva do C. muitas vezes é omitida por ser mais óbvia (...) $2^{\circ}$. A segunda função atribuída ao C. é a econômica. A essa função vincula-se caráter classificador do C. (...) $3^{\circ}$ A terceira função do C. é organizar os dados da 
A origem etimológica da palavra PESSOA, da qual derivam os termos IMPESSOAL e IMPESSOALIDADE, ensina Hannah Arendt, "foi adotada quase sem alterações do latim persona pelas línguas europeias" e se referia "em latim à máscara do ator, aquela que cobria a sua face 'pessoal' individual, indicando para o espectador o papel e a parte do ator na peça. Mas nessa máscara, que era criada e determinada para a peça, havia uma abertura larga no lugar da boca, pela qual soava a voz individual e sem disfarce do ator. É desse soar através que a palavra persona derivou originalmente: per-sonare, 'soar através', é o verbo do qual persona, a máscara, é o substantivo. E os próprios romanos foram os primeiros a usar o substantivo num sentido metafórico; na lei romana, persona era alguém que possuía direitos civis, em contraste agudo com a palavra homo, que denotava alguém que não passava de um membro da espécie humana, diferente, sem dúvida, de um animal, mas sem nenhuma qualificação ou distinção específica, de modo que homo, como o grego anthropos, era frequentemente usado de modo desdenhoso para designar pessoas não protegidas pela lei" ${ }^{\prime 191}$.

A escritora alemã continua seu raciocínio observando que a expressão pessoa a convida a outros usos metafóricos do termo, acrescentando que a "máscara romana corresponde com grande precisão ao nosso modo de aparecer na sociedade, onde não somos cidadãos, isto é, onde não estamos igualados pelo espaço público estabelecido e

experiência de modo que se estabeleçam entre eles nexos de natureza lógica (...) $4^{\circ}$ A quarta função do C., hoje considerada fundamental nas ciências físicas, é a previsão (...) Por ela, o C. é um meio ou procedimento antecipador ou projetante. Para Dewey, antecipa ou projeta a solução de um problema exatamente formulado (Logic, XX, §1; trad. it., p.516; cf. XXIII, §1, p. 599). Para outros, a função antecipadora do C. é o instrumento de que a ciência se serve 'para predizer a experiência futura à luz da experiência passada' (Quine, From a logical Point of View, II, 6). Este trabalho toma o termo CONCEITO, em relação ao princípio de impessoalidade, em sua função instrumental organizadora e preventiva da atividade administrativa.

189 Aqui a lição de Eros Roberto Grau: "Os conceitos jurídicos não são referidos a objetos, mas sim a significações. Não são conceitos essencialistas. O 'objeto' do conceito não existe 'em si'; dele não há representação concreta, nem mesmo gráfica. O objeto só existe 'para mim', de modo tal, porém, que sua existência abstrata apenas tem validade no mundo jurídico quando a este 'para mim', por força de convenção normativa, corresponde um - sejam-me permitida a expressão - 'para nós'. Apenas e tão somente na medida em que o 'objeto' - a significação - do conceito jurídico possa ser reconhecido uniformemente por um grupo social poderá prestar-se ao cumprimento de sua função, que é a de e permitir a aplicação de normas jurídicas com um mínimo de segurança e certeza" (GRAU, Eros Roberto. Porque tenho medo dos juízes (a interpretação/aplicação do direito e dos princípios). $6^{a}$ edição refundida do ensaio e discurso sobre a interpretação/aplicação do direito. São Paulo: Malheiros, 2013. p. 147).

${ }^{190}$ Etimologia é a disciplina linguística que estuda a origem das palavras, conforme GIACOMOZZI, Gilio et al. Dicionário de Gramática. São Paulo: FDT, 2004. No Dicionário de Filosofia se registra: "No sentido estrito, seria o estudo da verdadeira significação das palavras. De facto, é a disciplina que determina a origem das palavras e a evolução do seu sentido e, simultaneamente, da sua foram. Quando a filosofia recorre à etimologia é muitas vezes mais para fazer surgir uma questão do que para afirmar simplesmente uma filiação (...)”. (DUROZOI, G; ROUSSEL, A. Dicionário de filosofia. Maria de Fátima de Sá Correia (Trad.). Coimbra: Porto, 2000).

${ }^{191}$ ARENDT, Hannah. Responsabilidade e Julgamento. Edição Jerome Kohn, revisão técnica Bethânia Assy e André Duarte, tradução de Rosaura Einchenberg. São Paulo: Companhia das Letras, 2004. p. 74-75. 
reservado para o discurso e atos políticos, mas em que somos aceitos como indivíduos por nossos méritos, e, no entanto, de modo algum como seres humanos enquanto tais"192

É de se considerar útil esta menção ao texto de Hannah Arendt, na medida em que, além de explicar a origem do termo pessoa, ele agrega com felicidade a ideia de que com a máscara metaforicamente "não somos cidadãos", não somos considerados. Vale dizer, as máscaras permitem apenas ouvir a voz do ator e, por extensão, distinguir meritoriamente as pessoas na sociedade.

Além destas constatações, nota-se que nos dois verbetes o prefixo im (ou in,$i$ ) causa uma modificação significativa no sentido destes termos que vai além de sua expressão ordinária de negação ${ }^{193}$. Este prefixo também pode significar um "movimento para dentro" ${ }^{\prime 194}$, como ensejando uma introspecção, uma tomada de consciência.

De um modo mais singelo e coloquial, é possível dizer que a impessoalidade pode indicar que o agente deve aparecer no exercício de sua atividade administrativa sem máscara e sempre introspectivo.

Destas informações, poder-se-ia numa primeira aproximação conceber o princípio de impessoalidade intimamente relacionado a dois dos fundamentos da República Federativa do Brasil: a cidadania e a dignidade da pessoa humana ${ }^{195}$.

Acrescente-se, atento à nova ordem constitucional democrática $(\mathrm{CR}$, art. $1^{\circ}$, caput, e parágrafo único), que o aparecimento do agente no exercício da atividade administrativa se dá em ambiente democrático, que pressupõe a possibilidade de diálogo concreto (que tanto pode se dar por iniciativa da Administração Pública, quanto por iniciativa da Sociedade, em sua dimensão coletiva ou individual), formando uma relação jurídica multilateral e permeável e visível ${ }^{196}$ e tangível e crítica e finalisticamente pública.

${ }^{192}$ ARENDT, Hannah. Responsabilidade e Julgamento. Edição Jerome Kohn, revisão técnica Bethânia Assy e André Duarte, tradução de Rosaura Einchenberg. São Paulo: Companhia das Letras, 2004. p. 75.

193 "Conquanto de ordinário os prefixos in e des sejam pelos lexicógrafos considerados sinônimos, parecenos - afirma Carlos Góis - haver de um para outro leve e ligeira discrepância: o prefixo in supõe a inexistência absoluta de determinado fato ou atributo, ao passo que o prefixo des pressupõe a cessação de determinado fato ou atributo que existia anteriormente. Tomemos para exemplo os vocábulos impronunciar e despronunciar, ambos de largo emprego na processualística forense. 'Impronunciar o réu' é reconhecer desde logo a inexistência de base ou fundamento para a sua pronúncia; 'despronunciar o réu' é alterar um julgamento anterior, em que o mesmo réu fora pronunciado, é inocentá-lo após haver sido inculpado". (ALMEIDA, Napoleão Mendes de. Dicionário de Questões Vernáculas. 4ª ed. São Paulo: Ática, 1998. p. 263).

${ }^{194}$ CUNHA, Celso; CINTRA, Luís F. Lindley. Nova gramática do português contemporâneo,. $5^{\mathrm{a}}$ ed. Rio de Janeiro: Lexikon, 2008. p. 99-100, citando como exemplos ingerir, imigrar. Cegalla registra o prefixo "in" com indicando "para dentro, conversão em, tornar". (CEGALLA, Domingos Paschoal. Novíssima Gramática da Língua Portuguesa. São Paulo: Companhia Editora Nacional,1992. p. 95).

${ }^{195}$ Constituição da República, art. $1^{\circ}$, inc. II e III.

196 Sobre visibilidade do poder, interessante a lição de Norberto Bobbio ao identificar significados distintos da palavra público, tudo a indicar que em Direito as expressões podem ter significados muito próprios, tal 
Mas estas ideias ainda são insuficientes para conceituar ou compreender o princípio $^{197}$.

5. 1. Uma Razão Jurídica crítica como um predicado do princípio de impessoalidade

A noção de Razão Jurídica, no direito brasileiro, passa pela compreensão da realidade constitucional. Vale dizer, significa compreender os objetivos, a estrutura e o funcionamento do Estado brasileiro.

Discorrendo um pouco mais sobre a Razão Jurídica, assevera Alejandro Nieto que em "qualquer de suas duas acepções a Razão Jurídicas facilita os juristas, de um lado, a compreensão do Direito e a sistematização do Ordenamento Jurídico: um objetivo científico, por tanto, já que é como vai progredindo a ciência jurídica; e, por outro lado, não menos importante, facilita o manejo do Direito, ou seja, a execução, aplicação e cumprimento das normas. Dois processos que, acumulando-se, terminam incidindo na existência e operatividade do Direito. A Razão Jurídica, que inicialmente nasce como uma faculdade individual e subjetiva, tende inevitavelmente a objetivar-se mediante a acumulação e homogeneização de seus resultados em um bloco coletivo dominante e termina transcendendo de si mesma para incidir na vida real do Ordenamento Jurídico

A Razão Jurídica controla o Direito que ela contribui para criar, verifica se cumpre os objetivos previstos, se está adaptado às circunstâncias existentes no momento de seu nascimento e se evolui na mesma direção e com o mesmo ritmo delas. Em seu mais puro sentido helegiano é um motor de funcionamento constante mas ao tempo inteligente e autorreflexivo. Porque não apenas examina o Direito tal como está operando na vida

como o termo impessoal. Aliás, a lição é bastante pertinente ao que se pretende neste trabalho. Assim discorre o professor italiano: "Um dos lugares-comuns de todos os velhos e novos discursos sobre a democracia consiste em afirmar que ela é o governo do 'poder visível'. Que pertença à 'natureza da democracia' o fato de que 'nada pode permanecer confinado no espaço do mistério' é uma frase que nos ocorre ler, com poucas variantes, todos os dias. Com um aparente jogo de palavras pode-se definir o governo da democracia como o governo do poder público em público. O jogo de palavras é apenas aparente porque 'público' tem dois significados diversos, conforme venha contraposto a 'privado', Como por exemplo na clássica distinção entre ius publicum e ius privatum, transmitida pelos juristas romanos, ou a 'secreto', em cujo caso tem o significado não de pertencimento à 'coisa pública' ou ao 'Estado', mas de 'manifesto', 'evidente', mais precisamente de 'visível'. Exatamente porque os dois significados não coincidem, um espetáculo público pode muito bem ser um negócio privado e uma escola privada (no sentido de que não pertence ao Estado) não pode subtrair-se à publicidade de seus atos. Assim, nada elimina do caratê privado do poder o pai de família, conforme a distinção entre direito privado e direito público, a devida publicidade de muitos atos de sua gestão, e nada elimina do caráter público do poder de um soberano autocrático o fato de que este poder seja exercido, em numerosas circunstâncias, no máximo segredo" (BOBBIO, Norberto. $O$ futuro da democracia. Marco Aurélio Nogueira (Trad.). São Paulo: Paz e Terra, 2000. p. 98).

197 A propósito, pelo que se infere deste estudo, poder-se-ia ampliar o sentido do verbete IMPESSOAL: tangível, permeável; controlável, passível ou tendente ao controle; submisso, responsivo; que considera, que não age sem indiferença. Em sentido figurado: sem máscara. 
social, mas também examina o direito tal como ela mesma está operando o Direito. Tal é sua peculiaridade mais notável, como um piloto que se autorregula e autoajusta: uma atividade tanto mais necessária quanto que, como humana que é, adoece de grave deficiências.

As forças sociais e o Poder político criam certamente o Direito; mas o funcionamento dele está condicionado e controlado pela Razão Jurídica, que o orienta de vários modos.

Em primeiro lugar com umas regras técnicas convencionais, que hierarquizam e articulam as diferentes classes de normas, que estabelecem os critérios de interpretação e aplicação e fixam as consequências reais de seu cumprimento e descumprimento. Por certo o surpreendente aqui é que o núcleo originário da Razão Jurídica não é jurídico, pois, como já se disse mais atrás, se serve da gramática, da lógica, da eficácia, da razoabilidade e, sobretudo, da experiência.

A Razão Jurídica é o forno onde se fundem todos estes elementos para convertê-los em uma ferramenta jurídica presos pela experiência e com o carimbo final da Justiça.

Atualmente o que habita predominantemente a Razão Jurídica são dogmas técnicos de índole jurídica, recebidos em parte do Direito romano pós-clássico e reelaborados no século XIX pelos exegetas franceses e, mais refinadamente, pela pandectista alemã: um lugar extraterrestre povoado por conceitos fantasmais como terminou confessando Ihering. E junto a estes dogmas ideológicos que, enquanto 'crenças' orteguianas, não necessitam justificação nem aceitam a crítica.

Muitos destes são princípios ideológicos em estado puro (...), outros culturais (criminalização dos atos contra a natureza ou tolerância dos homicídio por motivo de adultério), outros econômicos (em defesa da liberdade de mercado), outros jurídicos (sacralização das formas) bem seja por invocações abstratas de Justiça ('dar a cada um o seu') ou por transcrição de velhos aforismos romanos descontextualizados (...). O assombroso, em definitivo, é que o Direito se oriente, interprete e aplique ou bem com técnicas não jurídicas (segundo acaba de apontar-se acima) ou por impulso de umas crenças não racionais - cabalmente porque são crenças não submetidas a juízo nem a dúvida - e ordinariamente não jurídicas.

Apresando as coisas, à Razão Jurídica incumbe não apenas orientar o Ordenamento Jurídico vigente (segundo se está dizendo) mas em último extremo indagar o sentido que tem - o deveria ter - em cada momento histórico, que não pode ser sempre o 
mesmo. As leis mudam com rapidez e com elas o conteúdo concreto do Direito; mas também muda, ainda que seja em ritmo distinto, a função do Direito, ou seja, o que a Sociedade espera dele.

Pois bem, se as construções jurídicas reflexo da vontade estatal não conseguem modificar a realidade e se queremos que umas e outra deixem de correr paralelas sem juntar-se nunca, não tem outro caminho que o de adaptar o sistema jurídico à realidade e não o inverso, como havia tentado o juspositivismo. A recuperação da unidade perdida exige, portanto, uma retificação do sistema: uma nova ideia de Direito, elaborada da realidade. Se a montanha não quer ir até o profeta, terá este que abandonar seu orgulho e olvidar os muitos dogmas para poder assim deslocar-se - sem imposições inúteis e com os olhos bem abertos - até á montanha."198

Adiante, Alejandro Nieto informa que "A Razão Jurídica tem de ser, antes de tudo, crítica, posto que é esta a qualidade que dá sentido à autorreflexão. O ser humano, segundo já apontou Kant, é um 'animal crítico', já que sem a crítica - e a autocrítica - estaria à mercê das forças naturais e de seus próprios impulsos. A crítica da Razão Jurídica se realiza - e não’é um jogo de palavras - por uma Razão Jurídica crítica que se manifesta em duas vertentes: uma externa que se refere ao Direito, e outra interna ou autocrítica, cujo objeto é ela mesma.

A crítica do Direito é uma atividade essencial porque a condição instrumental deste - sua submissão ao Poder político - o faz singularmente vulnerável, cúmplice poderia dizer, de todo a classe de desvarios e obriga, portanto, a uma atenção permanente, que nem sempre se dá.

A 'maldade' humana não costuma atuar a descoberto, mas gosta de mascarar-se com proteções religiosas ou jurídicas. Quando um povo conquista o outro, termina legitimando-se de alguma maneira; quando uma classe domina a outra, tende a justificar em razões de Justiça e em todo caso adormecendo sua consciência com as ‘fórmulas políticas' que já conhecemos. As religiões e as morais mais estritas tem admitido com toda naturalidade a escravidão, a exploração dos povos, as guerras de conquista e a miséria dos concidadãos. O Direito tem coberto sempre - e seguirá fazendo isso - todos os horrores imagináveis. A judicialização dos crimes de guerra é um poder que pertence exclusivamente aos vencedores, já que os únicos que os comentem são os vencidos.

198 ALEJANDRO NIETO. Crítica de la Razón Jurídica. Madrid: Editorial Trotta, 2007. pp. 25-27 (tradução nossa). 
Quando a Razão Jurídica fecha os olhos diante deste fenômenos e cala, é infiel a si mesma porque se as sujeições do Direito são inevitáveis, e até confirme com sua natureza, a Razão Jurídica deve ser livre, crítica e, por fim, autocrítica, vigilante de suas carências. Tem de estar muito atenta porque, de não ser assim, tende a ser conformista no substancial e autocomplacente com suas técnicas. A Razão Jurídica dogmática e indiferente, á vontade consigo mesma, não tolera que se ponha em dúvida a feliz harmonia que reina entre o Direito e o Poder que tanto beneficia os juristas e os políticos.

Todas as críticas, enfim, resultam incômodas. A crítica da Razão Jurídica atua como a espada de Pizarro riscando uma linha na arena e forçando os homens a colocar-se em um lado ou em outro dela: ou em direção à aventura ou a continuar descansando. A crítica da Razão Jurídica obliga o jurista a tomar partido sobre certas questões que já não pode seguir ignorando como, entre outras muitas, as que se denunciam e analisam nestas páginas. O melhor exemplo histórico de nobre exercício da Razão Jurídica crítica é o conhecido caso de sir Edward Coke quando em 1612 se opôs às pretensões judiciais do monarca com as seguintes palavras: 'As causas concernentes à vida, à herança, aos bens e à forma dos vassalos não se decidem segundo a lei natural, mas pela Razão e pela lógica convencional das leis, que é uma arte que requer muitos estudos e muita experiência antes que um homem possa dizer que a conhece'.

Tal como reza seu título convém adiantar que na presente obra o que se desenvolve com detalhe é a vertente autocrítica da Razão Jurídica, não a crítica que faz esta do Direito ou, por dizer com outras palavras, a crítica que faz a Razão Jurídica reta da Razão Jurídica desviada",199.

${ }^{199}$ ALEJANDRO NIETO. Crítica de la Razón Jurídica. Madrid: Editorial Trotta, 2007. pp. $27-28$ (tradução nossa). 


\section{VI - ALGUNS INTÉRPRETES DO BRASIL E A EXPERIÊNCIA}

\section{ADMINISTRATIVA: A RELAÇÃO ENTRE ESTADO, DIREITO E SOCIEDADE}

\section{1 - Considerações iniciais: a ideia de Patrimonialismo}

É na condição de colônia de Portugal, argumenta Luís Roberto Barroso $^{200}$, que o Brasil - produto de uma monarquia absoluta - "herdou" o ranço das relações políticas, econômicas e sociais de base patrimonialista, "que predispõem à burocracia, ao paternalismo, à ineficiência e à corrupção" 201.

Para este autor, entende-se por Patrimonialismo a "apropriação da coisa pública como se fosse uma possessão privada, passível de uso em benefício próprio ou dos amigos, ou ainda em detrimento de inimigos".

Para ele, apesar de séculos já passados, ainda que a Constituição da República de 1988 tenha melhorado a institucionalização do poder, a "triste verdade é que o Brasil jamais se libertou dessa herança patrimonialista".

Entretanto, Luís Roberto Barroso reconhece que a "Constituição de 1988, o mais bem-sucedido empreendimento institucional da história brasileira, demarcou, de forma nítida, alguns espaços privados merecedores de proteção especial. Estabeleceu, assim, a inviolabilidade da casa, o sigilo das correspondências e das comunicações, a livre iniciativa, a garantia do direito de propriedade, além de prometer a proteção da família. Seu esforço mais notável, contudo, é o de procurar resguardar o espaço público da apropriação privada, o que faz mediante normas que exigem concurso para ingresso em cargo ou emprego público, licitação para a celebração de contratos com a Administração Pública, prestação de contas dos que administram dinheiro público, bem como sancionam a improbidade administrativa. Proibição emblemática, que em si abriga mais de cem anos de República desvirtuada, é a do art. $37, \S 1^{\circ}$, que interdita autoridades e servidores de utilizarem verbas públicas para promoção pessoal".

Examinando a doutrina aqui reunida, percebe-se que é nesse contexto de Patrimonialismo que ela parece tirar inspiração e pensar este princípio constitucional.

\footnotetext{
200 BARROSO, Luís Roberto (org.). A reconstrução democrática do direito público no Brasil. Rio de Janeiro: Renovar, 2007. p. 66.

${ }^{201}$ BARROSO, Luís Roberto . Curso de direito constitucional contemporâneo: os conceitos fundamentais e a construção do novo modelo. São Paulo: Saraiva, 2009. p. 66-68.
} 
Por certo o princípio em questão não é estranho a esta realidade, mas ele não tem como elemento normativo a imposição de conduta imparcial, objetiva, neutra ou ainda igualitária, como pretende a doutrina aqui examinada.

Este princípio de impessoalidade surge não exatamente deste fenômeno, mas da estrutura jurídico-administrativa existente que o alimentou, e bem poderia ser incluído entre estes mecanismos de resguardo do espaço público da apropriação privada, como observou o professor, hoje também ministro do Supremo Tribunal Federal.

\subsection{O início do Direito Administrativo no Brasil: algumas ideias}

Examinando o Direito Administrativo mais remoto aplicado no Brasil, é possível ter uma noção um pouco mais aclarada da realidade histórico-jurídicoadministrativa nacional e, a partir daí, aprofundar a investigação sobre o princípio de impessoalidade.

As divergências no Direito Administrativo, como já se observou ${ }^{202}$, são encontradiças. Não se limitam a seus institutos, à origem da disciplina etc.

As causas remotas que parecem ter inspirado o surgimento do princípio de impessoalidade estão relacionados ao direito substancial e processual do Império.

Este estudo, embora não exaustivo, parte da premissa de que a estrutura jurídico-administrativa imperial contribuiu para o advento deste ainda incógnito e indecifrável princípio constitucional.

Em outras palavras, aquilo que se tem denominado Patrimonialismo ${ }^{203}$ é menos causa do que consequência desta estrutura jurídico-administrativa do Brasil ${ }^{204}$.

\footnotetext{
202 Já se registrou este tema nas notas de rodapé n. 19 e 101.

${ }^{203}$ Também a esse propósito, vale lembrar o registro de Raymundo Faoro: "O capitalismo politicamente orientado - o capitalismo político, ou o pré-capitalismo -, centro da aventura, da conquista e da colonização moldou a realidade estatal sobrevivendo e incorporando na sobrevivência o capitalismo o capitalismo moderno, de índole industrial, racional na técnica e fundado na liberdade do indivíduo - liberdade de negociar, de contratar, de gerir a propriedade sob a garantia das instituições. A comunidade política conduz, comanda, supervisiona os negócios, como negócios privados seus, na origem, como negócios públicos depois, em linhas que se demarcam gradualmente. O súdito, a sociedade, se compreendem no âmbito de um aparelhamento a explorar, a manipular, a tosquiar nos casos extremos. Dessa realidade se projeta, em florescimento natural, a forma de poder, institucionalizada num tipo de domínio: o patrimonialismo, cuja legitimidade assenta no tradicionalismo - assim é porque sempre foi. O comércio dá o caráter à expansão, expansão em linha estabilizadora, do patrimonialismo, forma mais flexível do que o patriarcalismo e menos arbitrária que o sultanismo". (FAORO, Raymundo. Os donos do poder: formação do patronato político brasileiro. $3^{\mathrm{a}}$ ed. rev. São Paulo: Globo, 2001. p. 819).

${ }^{204}$ Cremos que aqui também surge outra divergência que pode integrar aquele extenso rol de divergências, conforme já foi exemplificado antes, existentes no estudo do Direito Administrativo.
} 
Retomando, de passagem, o tema do nascimento do Direito Administrativo, Odete Medauar ${ }^{205}$ informa que autores franceses, italianos e brasileiros apontam a Lei do 28 pluvioso do ano VIII (1800) como o "ato de nascimento do direito administrativo". Entretanto, anota que Prosper Weil "prefere situar a origem do direito administrativo entre a Revolução de 1789 e o fim do Segundo Império (1870)”.

De fato esta divergência não parece interferir na formação da organização administrativa francesa, mas a referida lei francesa, na lição de Zanobini, citado por Odete Medauar, "pela primeira vez deu à administração francesa uma organização juridicamente garantida e exteriormente obrigatória”.

Baseando-se na lição de Debbasch, Odete Medauar registra que naquela lei francesa dois princípios nortearam a organização administrativa: o da hierarquia e o da centralização. Especificamente sobre o primeiro princípio, “fixou-se de modo claro, pela primeira vez, a separação entre o representante que exerce funções no âmbito político e o funcionário, que atua no setor administrativo, totalmente subordinado àquele".

As justificativas para a adoção de hierarquia rígida e estrutura centralizada, continua Odete Medauar, está na "necessidade de abolir a desordem, então existente na Administração francesa, em decorrência do tumultuado período revolucionário, além da conhecida tendência de Napoleão a exercer o poder do modo mais amplo possível".

Pertinente lembrar a lição de Maria Sylvia Zanella Di Pietro, ao discorrer sobre a origem do Direito Administrativo, sobre o aumento de seu campo de aplicação e da necessidade do desenvolvimento das regras aplicáveis às relações com o Estado. Desenvolvimento este, frise-se, que envolve a compreensão do princípio de impessoalidade.

Diz a professora ${ }^{206}$ que "Não se afigura verdadeira a tese de que o Direito Administrativo só exista nos sistemas europeus formados com base nos princípios revolucionários do século XVIII. O que é verdadeiro é o fato de que nem todos os países tiveram a mesma história nem estruturaram pela mesma forma o seu poder; em consequência, o Direito Administrativo teve origem diversa e desenvolvimento menor em alguns sistemas, como o anglo-americano. Mesmo dentro dos 'direitos' filiados ao referido sistema europeu existem diferenças que vale a pena assinalar, uma vez que, quanto menos

205 MEDAUAR, Odete. O direito administrativo em evolução. São Paulo: Editora Revista dos Tribunais, 1992. p. 10-11.

${ }^{206}$ DI PIETRO, Maria Sylvia Zanella. Direito Administrativo. $25^{\mathrm{a}}$ ed. São Paulo: Atlas, 2012. p. 3. 
desenvolvido o Direito Administrativo, maior é a aplicação do direito privado nas relações jurídicas de que participa o Estado.

Na realidade, o conteúdo do Direito Administrativo varia no tempo e no espaço, conforme o tipo de Estado adotado. No chamado Estado de Polícia, em que a finalidade é apenas a de assegurar a ordem política, o objeto do Direito Administrativo é bem mais amplo, porque menor é a interferência estatal no domínio da atividade privada. O Estado do Bem-estar é um Estado mais atuante; ele não se limita a manter a ordem pública, mas desenvolve inúmeras atividades na área da saúde, educação, assistência e previdência social, cultura, sempre com o objetivo de promover o bem-estar coletivo. Nesse caso, o Direito Administrativo amplia seu conteúdo, porque cresce a máquina estatal e o campo de incidência da burocracia administrativa. O próprio conceito de serviço público amplia-se, pois o Estado assume e submete a regime jurídico publicístico atividades antes reservadas aos particulares. Além disso, a substituição do Estado liberal, baseado na liberdade de iniciativa, pelo Estado-Providência ampliou, em muito, a atuação estatal no domínio econômico, criando novos instrumentos de ação do poder público, quer para disciplinar e fiscalizar a iniciativa privada, com base no poder de polícia do Estado, quer para exercer atividade econômica, diretamente, na qualidade de empresário. Também sob esse aspecto, ampliou-se o conteúdo do Direito Administrativo, a ponto de já se começar a falar em novo ramo que a partir daí vai-se formando - o direito econômico ${ }^{207}$ - baseado em normas parcialmente públicas e parcialmente privadas".

Enfim, o que se nota é que o contexto histórico e legislativo (regras e forma de Estado) influencia (e, por vezes, orienta mesmo, quase que como uma imposição) a doutrina administrativista de sua época. Tal orientação e influência, saliente-se, incluem o modo de interpretar as regras de direito substancial e as de funcionamento do Estado.

A propósito, o fato de se tratar de um ambiente monárquico (de direito ou de fato), por seu espírito próprio, inevitavelmente limitará o intérprete, por vezes, impedindo-o de criticar o próprio sistema, restringindo sua reflexão, e, por conseguinte, impedindo que alterações e adaptações necessárias em sua época fossem implementadas.

\footnotetext{
${ }^{207}$ São aqueles direitos que os professores portugueses Marcelo Rebelo de Sousa e André Salgado de Matos denomina de direitos transversais (SOUSA ,Marcelo Rebelo de; MATOS, André Salgado de. Direito Administrativo Geral - Introdução e princípios fundamentais. $3^{\mathrm{a}}$ ed. Portugal: D. Quixote, 2010. p. 85. Tomo $1)$.
} 


\section{Consultando Ensaio sôbre o Direito Administrativo ${ }^{208}$, encontramos}

concepções sobre a divisão do Poder Executivo e suas competências que bem revelam e continuam inspirando comportamentos na Administração Pública ainda hoje!

De modo mais preciso e incisivo, Temístocles Brandão Cavalcanti ${ }^{209}$, na apresentação do livro, numa edição de 1960, anota que o "Direito Administrativo no Império é toda a construção da Jurisprudência administrativa feita pelo Conselho de Estado em suas diversas fases, é tôda a legislação sôbre terras, especialmente sôbre terrenos de marinha e terras devolutas, é a legislação de águas, de minas, é a legislação sôbre concessões ferroviárias e de portos, com traços marcantes e bem definidos, é o regime de garantias de juros, base do nosso desenvolvimento na origem da construção do nosso sistema de estrada de ferro e navegação etc.

\footnotetext{
${ }^{208} \mathrm{Na}$ apresentação de uma nova edição do livro em 1960, Temístocles Brandão Cavalcante escreveu: "A importância desta obra decorre principalmente da autoridade do seu autor, dos temas centrais que escolheu e desenvolveu, espelhando um Direito Administrativo que vigorava em 1862, com todas as características do livro daquela época. Quando o Visconde de Uruguai escreveu o seu ensaio, pouco, se havia feito em matéria de técnica administrativa, embora tivesse êle tido o perfeito sentimento de que o Direito Administrativo, só se destacará do Direito Constitucional ou do Direito Político, em razão do surgimento dessa técnica da administração, sem a qual também nenhum sentido teria o direito próprio à administração pública" (URUGUAI, Visconde de. Ensaio sôbre o Direito Administrativo. Themístocles Brandão Cavalcanti (apres.). Rio de Janeiro: Serviço de Documentação do Ministério da Justiça e Negócios Interiores, 1960. p. I). A propósito, anote-se a definição de Direito Administrativo adotado por Paulino Soares de Sousa: "Adotarei a definição que dá Laferrière, a qual me parece mais compreensiva e satisfatória, mediante algum desenvolvimento. O direito administrativo pròpriamente dito, diz ele, é a ciência da ação e da competência do Poder Executivo, das administrações gerais e locais, e dos Conselhos Administrativos, em suas relações com os interesses ou direitos dos administrados, ou com o interêsse geral do Estado" (p. 19). Sobre o tema da descentralização e centralização administrativa, observa o autor: "Se há grande centralização administrativa no país, prepondera, ainda nas localidades, ação e a competência do poder administrativo geral. Se há grande descentralização, avulta nelas a ação e competência das autoridades locais" (p. 19).

${ }^{209}$ URUGUAI, Visconde de. Ensaio sôbre o Direito Administrativo. Themístocles Brandão Cavalcanti (apres.). Rio de Janeiro: Serviço de Documentação do Ministério da Justiça e Negócios Interiores, 1960. p. II e VII. Interessante o registro do apresentador sobre o autor da obra apresentada: "Sente-se no autor o político preocupado com os problemas gerais da administração, com o valor e significação das instituições políticas e administrativas vigentes e também o estudioso e erudito assoberbado com a quantidade do material acumulado, material legislativo e doutrinário, precisando com tudo isso construir uma obra que exprimisse a síntese de toda a doutrina que então prevalecia" (p. VII). Guerreiro Ramos assim se expressa sobre Visconde de Uruguai: "se destaca entre os que se preocuparam com os problemas administrativos do Brasil por ter sido o que se chama atualmente um pensador em situação. Parlamentar e ministro várias vezes no Império, teve relevante participação na elaboração de instituições durante decisivo período de nossa história política. Sua obra e ação podem ser consideradas precursoras do que hoje se denomina, nos Estados Unidos, institution building e nation building. Num momento em que a estrutura institucional da sociedade brasileira ainda em formação, isto é, cerca de duas décadas após a Independência, o Visconde de Uruguai não só interfere como político e estadista nas lutas em torno da concretização de medidas de construção nacional, como também formula os fundamentos teóricos de sua militância efetiva" (RAMOS, Alberto Guerreiro. Administração e Contexto Brasileiro: esboço de uma teoria geral da administração. $2^{\mathrm{a}}$ ed. Rio de janeiro: Ed. da Fundação Getúlio Vargas, 1983. p. 260). Ainda sobre Visconde de Uruguai, escreve Gabriela Nunes Ferreira, professora de Ciência Política na UNIFESP: "Dotado de grande habilidade e senso de oportunidade política, o visconde do Uruguai esteve na linha de frente do processo de construção e consolidação do estado imperial: monárquico, centralizado em torno do Rio de janeiro e calcado na escravidão" (FERREIRA, Gabriela Nunes. Um enigma chamado Brasil: 29 intérpretes e um país. In BOTELHO, André; SCHWARCZ, Lilia Moritz (orgs). São Paulo: Companhia das Letras, 2009. p. 20).
} 
É todo o debate em torno do contencioso administrativo, da competência dos tribunais administrativos e judiciais. É, ainda, a construção doutrinária, feita pelos professores e pelos tratadistas, como Uruguai, Ribas, Pereira do Rêgo etc.”

Mais adiante este professor da então Universidade do Brasil, completa que "O «<Ensaio »> contém o material necessário ao estudo do Direito Administrativo. Ali se estudam os elementos fundamentais do Direito Administrativo e principalmente a estrutura do Estado e da administração, o problema da centralização, do Poder Moderador, da administração graciosa e contenciosa, do Conselho de Estado.

O conteúdo próprio das normas administrativas não estava ainda bem caracterizado.

Afora, portanto, os elementos básicos de direito administrativo bem expostos no principio da obra, o autor deu singular importância a duas instituições fundamentais da política Constitucional do Império e que teriam influência preponderante no desenvolvimento do nosso direito administrativo e do nosso direito político - o poder Moderador e o Conselho de Estado".

Nesse contexto, percebe-se que a Sociedade estava em segundo plano. Ela não integrava as preocupações do objeto de estudo do Direito Administrativo. Algo como se disséssemos que tal preocupação fosse coisa de sociólogos ${ }^{210}$.

No período do Império, segundo Paulino Soares de Sousa, o Poder executivo era dividido em poder executivo puro e em poder administrativo, surgindo, daí, a distinção entre governo e administração. Nesta divisão, o poder executivo puro (também chamado político ou governamental) era exercido "pelo Chefe do Poder Executivo e seus ministros, direta e indiretamente", e o poder administrativo por "uma série de agentes responsáveis e amovíveis" ${ }^{211}$.

“O poder executivo, como Govêrno, aplica por si só e diretamente as leis de ordem política, constituindo a ação governamental. Quase nunca, exceto quando nomeia, se ocupa de indivíduos; e procede regulando e decidindo generalidades. Provê, por medidas gerais, à segurança interna e externa do país, e à execução das leis; completandoas quando é isso indispensável para lhes dar vida e execução, por meio de regulamentos e medidas gerais, com caráter muitas vêzes permanente. Dá o impulso geral aos

\footnotetext{
${ }^{210}$ Nossa nota de rodapé n. 38 sobre ALEJANDRO NIETO. Crítica de la Razón Jurídica. Madrid: Editorial Trotta, 2007. pp. 30-31 (tradução nossa).

211 URUGUAI, Visconde de. Ensaio sôbre o Direito Administrativo.Themístocles Brandão Cavalcanti (apres.). Rio de Janeiro: Serviço de Documentação do Ministério da Justiça e Negócios Interiores, 1960.p. 53.
} 
melhoramentos morais e materiais que convém introduzir nos negócios públicos; nomeia para os diversos cargos, demite, aposenta, e exerce certa disciplina sobre seus agentes. Exerce certas delegações que lhe dá o poder legislativo.

Êsse Poder não pode deixar de ser centralizado, e de ter, porque é responsável, certa largueza e liberdade de ação, para mover-se, contanto que se contenha nos seus limites constitucionais, e dentro do círculo das leis. O exercício de suas atribuições, depende de circunstâncias que não é sempre possível prever e fixar, de uma apreciação larga de grandes interesses sociais que não pode ser sujeita a regras minuciosas, nem a uma marca complicada e morosa, e à fieira de uma hierarquia de funcionários" ${ }^{212}$.

O "poder administrativo" aplica "o interêsse geral a casos especiais, pondo-se em contato com o cidadão individualmente, e vê-se muitas vezes na necessidade de sacrificar o interêsse particular deste e mesmo o seu direito ao interêsse social". Este poder é dividido "em poder administrativo gracioso, e contencioso, ou em administração graciosa e contenciosa". "A administração é graciosa quando os seus atos, fundados em interêsse geral, somente podem ferir ou ferem o interesse particular, dada a colisão entre esses dois interêsses",213.

Logo em seguida, citando Adolphe Chauveau, Paulino Soares de Sousa observa que esta distinção é "a chave da competência administrativa".

"A administração graciosa, atributo e instrumento essencial do Poder Executivo, procede discricionàriamente, e com arbítrio; o que não quer dizer que o seu poder é absoluto, porquanto tem por limites as leis, e os direitos.

Toma, dentro do círculo de suas atribuições e na conformidade das leis, as medidas que julga convenientes ao interêsse geral da sociedade. Ninguém as pode atacar ou discutir quer perante os tribunais ordinários, quer perante os tribunais administrativos. Das decisões da administração graciosa, há somente o recurso gracioso (...)

Em matéria de interesse, e no caso de colisão entre os dois particulares e os da sociedade, não pode deixar de haver na administração certo poder discricionário para resolver. A lei não pode prever e regular com antecipação a sua aplicação a cada um dos casos que se há de apresentar, avaliando, com prevenção os interesses, que, em cada hipótese particular, há de surgir e entrar em jogo.

212 URUGUAI, Visconde de. Ensaio sôbre o Direito Administrativo. Themístocles Brandão Cavalcanti (apres.) Rio de Janeiro: Serviço de Documentação do Ministério da Justiça e Negócios Interiores, 1960.p. 54.

${ }^{213}$ Idem, ibidem. p. 56. 
O Govêrno, por exemplo, é autorizado a mandar fazer, por empreitada, uma obra pública, ou a conceder minas para exploração, com tais e tais condições. São Pretendentes Pedro, João e Antônio, e satisfazem as condições da lei. A administração prefere Pedro. Fere os interêsses de João e Antônio, mas não o seu direito. Nem a lei podia prever o caso e determinar que, apresentando-se os três, fôsse a concessão feita, por exemplo, a João. Se fôsse possível fazê-lo e o fizesse, o poder legislativo invadiria o executivo e administraria" 214

A preocupação do Direito Administrativo estava focado na hierarquia e na centralização, não havendo preocupação com o cidadão, com a coletividade, tampouco com a qualidade da atividade pública prestada, que mais parecia uma "benevolência" 215 do Estado, um "ato de grandeza" do Poder.

"Se é evidente que a administração não deve ficar peada quando da promoção do bem público e no cumprimento dos deveres que lhe impõem as leis, encontra obstáculos nos interêsses e em certos direitos dos particulares, é também evidente que êsses interesses e direitos não devem ficar abandonados à mercê de mero arbítrio. Devem a organização e as leis administrativas dar-lhes garantia de audiência, de discussão, de exame, de conselho, de publicidade e de recurso, para a consideração, e reconsideração dos assuntos.

Nesta parte a nossa legislação é extremamente deficiente e arbitrária, e não oferece garantias suficientes, como teremos ocasião de observar"216.

214 URUGUAI, Visconde de. Ensaio sôbre o Direito Administrativo. Themístocles Brandão Cavalcanti (apres.). Rio de Janeiro: Serviço de Documentação do Ministério da Justiça e Negócios Interiores, 1960. p. 57-58.

215 Sobre um exemplo de benevolência do Estado, a lição de Eduardo Garcia de Enterría: “a justiça administrativa, que se consolidou por meio da ferramenta basilar do excès de pouvoir, articulou-se sobre o princípio básico da 'separação' entre a justiça e a Administração, do qual se extraiu todo o seu caráter 'objetivo'. Em face deste caráter, o recorrente na fazia valer qualquer direito subjetivo, cuja proteção pudesse ser postulada e obtida no processo (conforme quedava claro, em virtude de a eventual desistência da ação, por parte do demandante, não ensejar o fim do processo), mas sim, apenas, o princípio abstrato e geral da legalidade da Administração. O dito recorrente atuava, pois, conforme destacou a doutrina a partir de Hauriou, como um membro do Ministério Público, em prol da legalidade objetiva, porquanto nem o próprio interesse que serviu como elemento legitimador do processo detinha qualquer relevância jurídica no momento da decisão. Assim, da eventual decisão anulatória, somente a posterior benevolência da Administração (de acordo com o seu próprio critério, de forma que essa atuasse como o arbítrio efetivo quanto à pertinência da execução, restando o Tribunal expressamente excluído) poderia resultar num benefício pessoal ao mencionado recorrente, benefício este que, desta feita, não estava incluído na decisão judicial". (ENTERRÍA, Eduardo Garcia de. As transformações da justiça administrativa: da sindicabilidade restrita à plenitude jurisprudencial. Uma mudança de paradigma? Fábio Medina Osório (Trad.); apresentação de Diogo de Figueiredo Moreira Neto. Belo Horizonte: Fórum, 2010. ), p. 93-94. (Coleção Fórum BrasilEspanha de Direito Público; 1).

${ }^{216}$ URUGUAI, Visconde de. Ensaio sôbre o Direito Administrativo. Themístocles Brandão Cavalcanti (apres.). Rio de Janeiro: Serviço de Documentação do Ministério da Justiça e Negócios Interiores, 1960. p. 62. 
Em outras palavras, existe um vazio normativo para regular a ação administrativa: uma verdadeira anomia ${ }^{217}$ aparentemente desejada pelos ocupantes do $\operatorname{poder}^{218}$.

Nota-se, então, que existem dois grupos de categorias relevantes para o Direito Administrativo imperial. A primeira é a distinção entre "interêsse" e "direito" 219 . A

${ }^{217}$ Em sociologia, "A anomia é uma situação social onde falta coesão e ordem, especialmente no tocante a normas e valores. Se normas soa definidas de forma ambígua, por exemplo, ou são implementadas de maneira casual ou arbitrária; se uma calamidade como a guerra subverte o padrão habitual da vida social e cria uma situação em que se torna obscuro quais normas têm aplicação; ou se um sistema é organizado de uma forma que promove o isolamento e a autonomia do indivíduo a ponto de as pessoas se identificarem muito mais com seus próprios interesses do que com os do grupo ou da comunidade como um todo - o resultado poderá ser a anomia, ou "falta de normas"' (JOHNSON, Allan G. Dicionário de Sociologia: guia prática da linguagem sociológica. Ruy Jungmann (Trad); consultoria Renato Lessa. Rio de Janeiro: Zahar, 1997, verbete ANOMIA. Aqui, novamente a lição de Gordillo, citando Eduardo Ortiz: "Há países da América Latina que tem regulações integrais do procedimento ante a Administração Pública, como a Argentina, Costa Rica, Peru, Venezuela, Uruguai: sem embargo, é fácil verificar que não há muitas diferenças reais entre o procedimento administrativo em ditos países e aqueles que se segue no Brasil, Equador, México, Paraguai, etc., países em que tal legislação não existe. É que em verdade a lei de procedimento administrativo, ainda que feita com o melhor critério jurídico, não se cumpre eficazmente senão aquele que tem de limitativo para o particular e de atribuição de potestades para a administração pública; enquanto a lei produz critérios de publicidade, razoabilidade, defesa do administrado, controle da atividade administrativa, etc., a realidade em geral pouco acolhe dos novos preceitos. Resulta disso que subsiste um procedimento administrativo real, com regras e princípios que conhecem e manejam os que se especializam por exemplo em gestões e trâmites, e um procedimento administrativo legislado que em parte coincide com aquele e em parte não. É como se fossem dois círculos parcialmente superpostos; enquanto ambos círculos se cortam, temos normas que são ao próprio tempo legais e reais, no que os círculos não têm contato, cada um tem normas que são alheias ao outro. Há assim normas legais que não se cumprem e normas reais que não estão nas leis" (GORDILLO, Agustín. La administración paralela: el parasistema jurídico-administrativo. $1^{\text {a }}$ ed. Madrid: Cuadersnos Civitas, 2001, pp. 50-51).

${ }_{218}$ A título de registro, mostra pertinente registrar aquilo que a sociologia denomina de Estruturas de oportunidade ("em uma sociedade é a distribuição do acesso aos empregos e outras maneiras de ganhar o sustento e atingir objetivos" - o citado dicionário, no verbete respectivo). Este conceito desempenha papel importante na teoria do desvio de Robert K. Merton: "Outra modalidade de formalismo decorre do que Robert K. Merton chama de deslocamento de objetivos, e, em grande parte, do conservadorismo que, segundo Mannheim, constitui característica inseparável de todo comportamento burocrático. À força da repetição, assinalou Merton, as normas e regras se impõem aos funcionários como preceitos sagrados. À certa altura da existência de tais normas e regras, os funcionários perdem de vista os objetivos para que foram criada e as aplicam de modo funcionalmente irracional. È de notar-se, segundo Merton assinalou, que essa rigidez de comportamento, embora prejudicial à sociedade em geral, ou aos consumidores dos serviços da burocracia, pode atender aos interesses investidos dos burocratas. Toda mudança que ameace tais interesses encontra a resistência dos burocratas, e, para tanto, o formalismo, o ritualismo, é o expediente a que soem recorrer" (apud RAMOS, Alberto Guerreiro. Administração e Contexto Brasileiro: esboço de uma teoria geral da administração. $2^{a}$ ed. Rio de janeiro: Ed. da Fundação Getúlio Vargas, 1983. p. 257-258).

${ }^{219}$ A despeito de se tratar de lição do Direito da fase imperial do Brasil, nota-se que a questão de distinção entre direitos e instrumentos jurídicos é bastante atual. Aqui, novamente a lição de Eduardo Garcia de Enterría: "O recurso contencioso administrativo deixou de ser concebido como um instrumento em defesa da legalidade, benevolentemente concedido aos cidadãos (...) Este instrumento processual (...) passa a ser agora, um verdadeiro direito subjetivo (fundamental, inclusive porquanto assegurado em um Tratado Internacional de Direitos Humanos) ${ }^{51}$, a saber, o direito de solicitar ao juiz a proteção de um direito material concreto, direito este que postula sua efetividade plena e completa, o que implica a necessidade de o juiz ser capaz de assegurá-lo (...) Não se trata, pois, de uma simples adição prática de novas prerrogativas, casuísticas, ao juiz, mas sim de algo mais substancial, a saber o reconhecimento de que o objeto da contenda apresentada pelo cidadão não é, conforme se pensava, um simples interesse mais ou menos inespecífico e oficial, que colocava em movimento uma justiça abstrata que não servia para atender. De forma alguma, a posição subjetiva do administrado, mas sim um verdadeiro direito subjetivo próprio, que postula como tal sua tutela completa e 
segunda, é que a partir dela se define o que vem a ser Administração graciosa e Administração contenciosa.

O interesse, ensina Paulino Soares de Sousa, “é o que é útil, o que importa, a vantagem que resulta para este ou aquêle indivíduo de que seja ou não adotada esta ou aquela medida administrativa pela administração.

É porém preciso, em direito administrativo, que êsse interêsse não seja reconhecido, e consagrado na lei, ou por um ato administrativo. Aliás assumiria a categoria de direito.

\section{Exemplos:}

Tem de ser aberta uma estrada. Um município que se acha na sua direção, pede que essa estrada passe pela sua vila. Tem nisso interêsse porque a passagem dos viandantes, e tropas, etc. poderá concorrer para aumentar a indústria e comércio dela. A administração decide que a estrada há de passar por outro lugar que julga mais conveniente. Foi ferido um interêsse importante, talvez justo, mas não foi ferido direito algum. A administração estava no seu direito, usos de uma faculdade discricionária, não estando indicados por lei os pontos pelos quais havia de passar a estrada.

Uma lei autoriza o Govêrno a fazer concessões de terrenos, de minas, etc. A administração indefere um pretendente, ou entre dois ou mais prefere um. Fere o interêsse dos outros, mas não o direito, porque o direito sòmente poderia resultar da concessão. Além de que a autoridade administrativa é então discricionária."220.

subjetiva (...) o processo contencioso administrativo foi colocado no mesmo patamar do processo civil entre as partes privadas, no qual, ninguém duvida, há o enfrentamento de duas pretensões equivalentes, no que se refere à titularidade em potencial dos mesmos direitos, respeitando-se o princípio básico de todo o litígio judicial (...) Ocorre, porém, que, atualmente, somente o direito alemão admite expressamente que, na técnica processual de qualquer recurso contra a Administração Pública, almeja-se a proteção de verdadeiros direitos subjetivos. O art. 19.4 da Grundgestz, ou Lei Fundamental de Bonn, estabeleceu o seguinte: 'Toda pessoa cujos direitos tenham sido vulnerados pelos poderes públicos tem o direito de obter a tutela efetiva dos juízes e tribunais". No direito público alemão, até o momento da aprovação do Grundgesetz, prevalecia um conceito altamente restritivo de direito subjetivo ${ }^{53}$, o que se fez com que seu sistema contenciosos administrativo funcionasse, até esse momento, de maneira insatisfatória. Será justamente o art. 19.4 da lei Fundamental que promoverá uma revolução que engendrará uma mudança substancial na doutrina tradicional. Frise que Otto Bachof desempenhou um papel decisivo nesta revolução, por meio de um trabalho justamente famoso ${ }^{54}$. A ideia básica por detrás desta nova fundamentação do conceito de direito subjetivo é a de que, no atual Estado de direito, todas as vantagens ou benefícios (Begünstigen) que possam derivar do ordenamento, para cada cidadão, se constituem em verdadeiros direitos subjetivos" (ENTERRÍA, Eduardo Garcia de. As transformações da justiça administrativa: da sindicabilidade restrita à plenitude jurisprudencial. Uma mudança de paradigma? Fábio Medina Osório (Trad.); apresentação de Diogo de Figueiredo Moreira Neto. Belo Horizonte: Fórum, 2010. ), p. 93-94. (Coleção Fórum Brasil-Espanha de Direito Público; 1. p. 95-99). As notas de rodapé não foram mencionadas porque não têm pertinência com o objeto em estudo.

${ }^{220}$ URUGUAI, Visconde de. Ensaio sôbre o Direito Administrativo. Themístocles Brandão Cavalcanti (apres.). Rio de Janeiro: Serviço de Documentação do Ministério da Justiça e Negócios Interiores, 1960. p. 62-63. 
Segundo Paulino Soares de Sousa, Macarel define a jurisdição graciosa e contenciosa da seguinte forma: “A jurisdição graciosa compreende tudo quanto é puro favor do soberano, tudo quanto emana do seu puro arbítrio, e da sua vontade espontânea. A contenciosa abrange tudo quanto põe um obstáculo legal à administração, quando no seu curso fere interêsses dos particulares" 221

Asseverando que a "a audiência da parte, de um conselho, e o exame de um tribunal administrativo são garantias importantes" ${ }^{222}$, Visconde de Uruguai observa que “O nosso contencioso administrativo não oferece todas essas garantias (...)

Assim, entre nós, o contencioso administrativo pode ser decidido pelo Poder Executivo puro, e pelo discricionário e gracioso. A distinção entre o gracioso e contencioso fica por esse modo sem alcance algum, e sujeita um mero arbítrio.

O nosso processo administrativo é muito deficiente e perfunctório como veremos oportunamente.

A publicidade, garantia importantíssima, não está organizada e desenvolvida como na França. E de pouco serviria uma vez que o Govêrno tem o arbítrio de subtrair as questões contenciosas e de decidi-las pelo meio discricionário.

As Consultas das Seções e do Conselho de Estado, não tem a fôrça e importância que têm, por exemplo, na França.

Não têm sido coligidos, nem se trata de coligir, as tradições e arestos, que podem servir, como na França servem, de regra e guia, pelo que a jurisprudência administrativa contenciosa é entre nós muito arbitrária e obscura, e apenas acessível aos que têm entrada nas secretarias, e coragem bastante para desempoeirar maços de papel enormes, onde tudo jaz sepultado no pó do esquecimento",223.

221 URUGUAI, Visconde de. Ensaio sôbre o Direito Administrativo. Themístocles Brandão Cavalcanti (apres.). Rio de Janeiro: Serviço de Documentação do Ministério da Justiça e Negócios Interiores, 1960. p. 64.

${ }^{222}$ Idem, ibidem. p. 85.

223 Idem, ibidem. p. 86-87. No capítulo XXII, o autor discorre sobre os processos e os recursos administrativos. "O processo ou instrução administrativa, isto é, o complexo das formalidades necessárias para pôr uns negócios em estado de ser decidido, reunidos todos os esclarecimentos e provas necessárias para o descobrimento da verdade, e da justiça, é também gracioso ou contencioso (...) A instrução graciosa, salvo quando as leis e regulamentos prescrevem alguma forma especial, é puramente discricionária, e não é portanto regida por princípios certos e invariáveis (...) O processo ou instrução contenciosa é estabelecido por leis e regulamentos, e exige a observância de certas formalidades, cuja violação deve importar a nulidade do procedimento havido" (p. 112). Sobre os recursos, registra o autor que "Umas das principais garantias que deve apresentar um sistema administrativo bem organizado é o dos recursos (...) Sendo os atos ou a jurisdição administrativa graciosos ou contenciosos, participam os recursos da natureza dessas duas espécies, isto é, há recursos por via graciosa, e recursos por via contenciosa (...) Portanto, pelo que respeita aos recursos, cumpre igualmente distinguir se foi lesado um interêsse, se um direito. O recurso dos atos graciosos porém não é rigorosamente um recurso; é mais pròpriamente uma simples reclamação, uma simples aplicação do direito geral de petição, então está sujeito a regras. Tem entre nós o seu fundamento no art. $179, \S^{\circ}$ da Constituição, 
Dividindo o Poder Executivo em "três qualidades diferentes", Paulino Soares de Sousa $^{224}$ registra este Poder pode atuar como governo, como administrador e como proprietário.

De maneira objetiva, sintetiza estas "qualidades":

“Como Govêrno, é o Poder Executivo puro, político e governamental.

Como proprietário e pessoa moral, possue, bem como as províncias e municipalidades, edifícios, terrenos, e outros bens, contrata, etc., etc."

Em seguida, distinguindo o que seria parte estranha ao Direito Administrativo, completa: "Pô-lo-ei de parte como Poder Executivo puro, político e governamental. Êsse assunto é da alçada do direito constitucional e político".

Mais adiante, esclarece, relativamente à "qualidade" de administrador, que "como administrador, o Estado tem Exército, tem Marinha, tem finanças; arrecada, despede, contrata, promove e executa grandes trabalhos públicos, vigia e provê sobre a polícia geral, sobre a segurança e salubridade pública, promove e fiscaliza a instrução, personifica o interesse público, e tem de absorver, ou modificar necessariamente certos direitos e certos interesses individuais, sacrificando-os aos gerais".

A obra de José Antônio Pimenta Bueno ${ }^{225}$, Marquês de São Vicente, intitulada Direito Público brasileiro e análise da Constituição do Império, também traz informações interessantes.

que o consagra sem restrição. O recurso contencioso se dá dos atos administrativos que ferem um direito, ou quando a lei o dá expressamente, nos casos e pela forma marcada nas leis e regulamentos. Tem uma organização especial. O recurso contencioso é expressamente admitido pela nossa legislação, É julgado dentro da esfera administrativa, e supõe nela superior hierárquico. Releva observar que as regras que regem o processo e os recursos administrativos contenciosos são menos rigorosas do que aquelas que regem o processo e recursos judiciais. A simplicidade e a celeridade, observa Chauveau Adolphe, formam o seu caráter distintivo; uma grande largueza é deixada ao poder discricionário, e as formas substanciais são em geral as únicas cuja preterição traz consigo a pena de nulidade” (pp. 112-113).

${ }^{224}$ URUGUAI, Visconde de. Ensaio sôbre o Direito Administrativo. Themístocles Brandão Cavalcanti (apres.). Rio de Janeiro: Serviço de Documentação do Ministério da Justiça e Negócios Interiores, 1960. pp. 60-61. Ruy Cirne Lima assim se manifesta sobre a Administração Pública: "Rege-se a Administração Pública pelo direito privado, excetuado o Contencioso Administrativo que meramente o aplica. Fora o direito provado, tudo se obscurece e confunde: - é o caos. Pode dizer-se, de resto, que é a expressão consagrada para caracterizar esse período de nossa Administração: 'administração no caos', chama-lhe o Visconde do Uruguai (Visconde do Uruguai, Ensaio sobre o Direito Administrativo, Rio de Janeiro, 1862, t. I, nota 1, p. 24) (...) Traço de nossa Administração Pública sob o Império é, pois, o que poderíamos denominar o privatismo, quer dizer, a subordinação da autoridade pública aos princípios e regras do direito privado" (LIMA, Ruy Cirne. Princípios de Direito Administrativo $7^{\mathrm{a}}$ ed., revista e reelaborada por Paulo Alberto Pasqualini. São Paulo: Malheiros, 2007. p. 63).

225 BUENO, José Antônio Pimenta, Marquês de São Vicente. Direito Público brasileiro e análise da Constituição do Império apud KUGELMAS, Eduardo (organização e introdução). José Antônio Pimenta Bueno, Marquês de São Vicente. São Paulo: Ed. 34, 2002. Sobre a biografia de Pimenta Bueno, o autor registra: "Se chegou às culminâncias do mundo político - conselheiro de Estado, senador, chefe de gabinete esta ascensão deveu-se a sua reputação de jurista e à manifesta simpatia do próprio d. Pedro II (...) Este seria 
Sobre o Pode Executivo, Pimenta Bueno informa que este "é a delegação da soberania nacional encarregada não só da execução das leis de interesse coletivo da sociedade, mas também da deliberação e impulsão, da segurança e gestão da lata administração do Estado (...)

Posto que o poder Executivo ou administrativo seja uma e a mesma coisa, ou sinônimos, todavia alguns publicistas, para melhor assinalar seu duplo caráter reservam-lhe para o caso em que ele é mero executor a denominação de poder administrativo, e para o caso em que ele promove e imprime sua impulsão ao Estado a de governo ou poder governamental. Com efeito, no primeiro caráter não é senão simples administrador ou executor das leis respectivas e de suas consequências; no segundo é muito mais importante, é o governo do país, menos a confecção das leis e ação da justiça particular, e salva a inspeção do poder Moderador e legislativo (...)

O poder Executivo é delegado ao imperador com seus ministros de Estado. Ele é o chefe, mas não o exerce por si, sim por estes agentes necessários e constitucionais, que completam e respondem por este poder (...)

Estas condições do poder Executivo não só oferecem as garantias que são indispensáveis à sociedade, mas são também elas que distinguem e separaram este do poder Moderador.

Daí também se infere que nos assuntos de maior importância faz-se necessário o acordo do pensamento do chefe do poder com os ministros, já porque ele tem o direito de demiti-los desde que falta esse acordo, já porque estes não podem nem devem em tais assuntos ir de encontro à sua convicção e consciência, e pelo contrário preferir desde então dar a sua demissão antes do que trair os seus deveres para com os direitos e públicos interesses",226.

Ao explicar o $\S \S 2^{\circ}$ e $3^{\circ}$, da Seção $2^{\mathrm{a}}$, Dos Diferentes Caracteres da Autoridade Executiva, "Da autoridade dos atos do poder executivo não suscetíveis de reclamação contenciosa" e "Da autoridade dos atos do poder Executivo suscetível de impugnação contenciosas", Pimenta Bueno assim leciona:

"O poder Executivo, mormente quando dirige o governo do Estado, sua marcha política, suas relações exteriores, sua segurança ou quando promove os interesses coletivos sociais ou mesmos trata de realizá-los ou regulamentá-los; quando ele é a alta

mais um homem do rei do que um dos barões, para retomarmos a expressão de José Murilo de Carvalho" (p. 19).

226 KUGELMAS, Eduardo (organização e introdução). José Antônio Pimenta Bueno, Marquês de São Vicente. São Paulo: Ed. 34, 2002 pp. 306-307. 
direção moral dos interesses gerais da nação, o instrumento de sua vida social, seu órgão de iniciativa, apreciação e impulsão, seu espírito e pensamento, pela natureza das coisas precisa ter uma ampla latitude de ação, livre escolha de meios. Sem isso não é possível que ele possa preencher bem a sua missão, servir bem a sociedade.

As instituições e as leis de um Estado civilizado preveem e reconhecem esta necessidade e, consequentemente, dão-lhes essa latitude, essa esfera não arbitrária, mas de uma discrição ilustrada, salvos sempre os limites dos poderes políticos e os direitos dos indivíduos (...)

Ora, enquanto sua ação ou atos são ditados dentro dessa órbita, enquanto respeitam os limites dos poderes, as leis e os direitos dos indivíduos, gozam não só de uma autoridade incontestável, mas produzem uma obrigação formal de inteira e inquestionável obediência., são atos ou determinações de inteiro império.

Em tal caso, não é admissível reclamação alguma contenciosa da parte dos cidadãos, resta-lhes apenas o recurso graciosos (...)

Quanto pelo contrário os atos do poder Executivo, em vez de conteremse só nessa latitude, ou órbita, infringem leis do Estado e, consequentemente, direitos individuais ou fórmulas protetoras desses direitos, então sua autoridade é suscetível de contestação de recurso contencioso.

Desde então a questão não é mais de mero interesse, é de um direito da infração de uma lei, de um abuso, é de justiça e não de discrição administrativa. Nenhum outro deve ser o princípio, pois que desde então, há, da parte da administração, violação de lei e a obrigação de reformar o seu ato; o contrário seria constituir a vontade ministerial como superior à lei, inutilizar ou aniquilar o poder Legislativo, e falsear, ou antes, destruir todo o sistema e garantias constitucionais, não haveria segurança de direitos.

Enquanto a administração não suscita tais reclamações é indiferente, como bem poderá Vivien ${ }^{44}$; examinar se suas medidas partem de sua autoridade limitada, ou de sua latitude discricionária; desde porém que há reclamação contenciosa cumpre reconhecer se, com efeito, trata-se de um simples interesse ou de um direito",227.

Na seção 5a, "Do processo perante o Conselho do Estado", no §1 ", "Do processo administrativo em geral", o autor afirma que "O processo perante o Conselho de Estado segue as condições do processo administrativo em geral, de que faz parte.

227 KUGELMAS, Eduardo (organização e introdução). José Antônio Pimenta Bueno, Marquês de São Vicente. São Paulo: Ed. 34, 2002. p. 308-310. Anote-se que a nota de rodapé 44 referida informa: “Alexandre François Vivien (1799-1854), homem de Estado francês, foi deputado, conselheiro de Estado e ministro da Justiça". 
A autoridade administrativa, para poder preencher sua variada e importante missão, pôr em prática seus pensamentos, realizar suas medidas e decisões, tem como os demais poderes necessidade de meios de informação, de exame e discussão, conforme a natureza dos negócios.

Precisa ver as coisas e suas diferentes faces, em suas diversas combinações, em seus meios de execução, e precisa também ser justa.

O seu processo, que deve ser rápido, isto é, calculado no sentido dos interesses públicos, mas também no sentido dos direitos dos cidadãos, pode ser dividido em duas espécies, processo de administração ativa ou pura, e processo do contencioso (...)

O processo administrativo puro, isto é, não contencioso, e que também se pode chamar de ativo ou gracioso, não tem termos, fórmulas, nem dilações ou condições fixas. É o complexo dos meios mais apropriados para esclarecer o assunto, ou a reclamação de que trata, ordenado segundo a natureza do negócio pela autoridade competente. Ou seja para tomar uma resolução, ou para atender à petição de um cidadão que reclama a favor de seus interesses, não dúvida que assim o ministério, como o Conselho de Estado ou suas seções, devem circundar-se de todos os esclarecimentos convenientes e combinar os interesses coletivos co os individuais quanto possível.

Não há leis precisas a respeito; as regras, o método de ilustração são indicados pela natureza da matéria, experiência e discretas instruções ministeriais.

É preciso verificar bem o verdadeiro interesse público, quando mesmo não se trate de execução de lei é necessário não atropelar as conveniências individuais. O interesse público é muito complexo, compõe-se de dessas conveniências, não atende só o presente, deve coordenar todas as previsões.

Este processo tem como que duas parte, as informações e a apreciação.

Como meios de informações pode a autoridade ouvir os que têm ou devem ter conhecimento da matéria, recorre à publicidade da imprensa, a concursos, inquéritos, planos, orçamentos, exame de peritos, coligir as observações das localidades, comono caso da direção que deva ter uma estrada, enfim, usar dos meios mais apropriados para o acerto da deliberação ou decisão.

A apreciação e consequente determinação compete peremptoriamente á autoridade. Como no caso deste processo não se trata de direitos e só sim de interesse, 
como já indicamos, a autoridade tem a inquestionável faculdade de formular sua decisão como for inspirada pela utilidade ou interesses coletivos da sociedade (...)" 228 .

Em síntese, de tudo o que se nota, a atividade do Poder Executivo era dividida arbitrariamente em duas esferas substanciais de atuação (administrativa e política, cuja distinção cabia ao próprio ocupante do poder, e não ao que hoje poderíamos dizer como 'estabelecidos na Constituição') e sua processualidade (em grande parte dependente do arbítrio deste ocupante) estava adequada (adaptada) estava regulamentada aos interesses "quase absolutos" do ocupante deste Poder.

De outra forma, havia perfeita simbiose $e^{229}$ entre substância (direitos e interesses) e instrumentalidade (processo administrativo) em função dos "negócios" do Poder que precisavam de "ampla latitude de ação, livre escolha de meios" sem a qual não era "possível (...) preencher bem a sua missão, servir bem a sociedade "230.

228 KUGELMAS, Eduardo (organização e introdução). José Antônio Pimenta Bueno, Marquês de São Vicente. São Paulo: Ed. 34, 2002 p. 384-385.

${ }^{229}$ Mutatis mutandis: “1. (Biol.) Associação entre dois ou mais organismos de espécies diferentes, em que são mantidas trocas metabólicas que garantem suas sobrevivência. (...) 3. Fig. Processo de associação entre pessoas ou coisas que gera dependência ou falta de autonomia" (DICIONÁRIO ESCOLAR DA LÍNGUA PORTUGUESA. Academia Brasileira de Letras. 2a ed. São Paulo: Companhia Editora Nacional, 2008, verbete respectivo. Interessante é o registro de Sérgio Buarque de Holanda a respeito do que se pode chamar de um reflexo desta simbiose: "É claro a necessidade de boa ordem entre os cidadãos e a estabilidade do conjunto social tornaram necessária a criação de preceitos obrigatórios e de sanções eficazes (...) Em verdade o racionalismo excedeu os seus limites somente quando, ao erigir em regra suprema os conceitos assim arquitetados, separou-os irremediavelmente da vida e criou com eles um sistema lógico, homogêneo, ahistórico. Nesse erro se aconselharam os políticos e demagogos que chamam a atenção frequentemente para as plataformas, os programas, as instituições, como únicas realidades verdadeiramente dignas de respeito. Acreditam sinceramente que da sabedoria e sobretudo da coerência das leis depende diretamente a perfeição dos povos e dos governo. Foi essa crença, inspirada em parte pelos ideais da Revolução Francesa, que presidiu toda a história das nações ibero-americanas desde que se fizeram independentes. Emancipando-se da tutela das metrópoles européias, cuidaram elas em adotar, como base de suas cartas políticas, os princípios que se achavam então na ordem do dia. As palavras mágicas Liberdade, Igualdade e Fraternidade sofreram a interpretação que pareceu ajustar-se melhor aos nosso velhos padrões patriarcais e coloniais, e as mudanças que inspiraram foram antes de aparato do que de substância" (HOLANDA, Sério Buarque de. Raízes do Brasil. 26a ed. São Paulo: Companhia das Letras, 1995. p. 178-179).

${ }^{230}$ Aqui cumpri relembrar a lição de Pimenta Bueno: “O poder Executivo, mormente quando dirige o governo do Estado, sua marcha política, suas relações exteriores, sua segurança ou quando promove os interesses coletivos sociais ou mesmos trata de realizá-los ou regulamentá-los; quando ele é a alta direção moral dos interesses gerais da nação, o instrumento de sua vida social, seu órgão de iniciativa, apreciação e impulsão, seu espírito e pensamento, pela natureza das coisas precisa ter uma ampla latitude de ação, livre escolha de meios. Sem isso não é possível que ele possa preencher bem a sua missão, servir bem a sociedade. As instituições e as leis de um Estado civilizado preveem e reconhecem esta necessidade e, consequentemente, dão-lhes essa latitude, essa esfera não arbitrária, mas de uma discrição ilustrada, salvos sempre os limites dos poderes políticos e os direitos dos indivíduos (...) Ora, enquanto sua ação ou atos são ditados dentro dessa órbita, enquanto respeitam os limites dos poderes, as leis e os direitos dos indivíduos, gozam não só de uma autoridade incontestável, mas produzem uma obrigação formal de inteira e inquestionável obediência., são atos ou determinações de inteiro império. Em tal caso, não é admissível reclamação alguma contenciosa da parte dos cidadãos, resta-lhes apenas o recurso graciosos (...) Quanto pelo contrário os atos do poder Executivo, em vez de conterem-se só nessa latitude, ou órbita, infringem leis do Estado e, consequentemente, direitos individuais ou fórmulas protetoras desses direitos, então sua autoridade é suscetível de contestação de recurso contencioso. Desde então a questão não é mais de mero interesse, é de um direito da infração de uma lei, de um abuso, é de justiça e não de discrição administrativa. Nenhum outro 
6.3. O registro de alguns intérpretes do período pós-imperial até a Constituição de 1988: a fase preponderantemente de ampliação do Estado

Na República ${ }^{231}$, assevera Themístocles Brandão Cavalcanti, "sofreu o Direito Administrativo uma certa pausa que quase o postergou das nossas disciplinas jurídicas. Nas duas primeiras décadas, quase nada sôbre êle se escreveu, seus problemas nenhum interêsse mereciam e talvez por isso mesmo, caímos em uma burocracia retardatária, cuja influência far-se-ia sentir até nossos dias.

Por outro lado, a falta de capacidade para isolar certos problemas do Estado das instituições privadas, refletiu-se prejudicialmente sôbre o desenvolvimento dessa disciplina

A unidade de jurisdição, ou melhor, a universalidade de jurisdição do Poder Judiciário ordinário, com a exclusão de qualquer outra instância administrativa especializada, imune à revisão dos órgãos judiciários comuns, não favorece a construção de doutrinas estranhas à formação intelectual dos juízes educados sobre a influência dos estudos romanistas e das construções jurídicas do direito privado" 232.

deve ser o princípio, pois que desde então, há, da parte da administração, violação de lei e a obrigação de reformar o seu ato; o contrário seria constituir a vontade ministerial como superior à lei, inutilizar ou aniquilar o poder Legislativo, e falsear, ou antes, destruir todo o sistema e garantias constitucionais, não haveria segurança de direitos. Enquanto a administração não suscita tais reclamações é indiferente, como bem poderá Vivien ${ }^{44}$; examinar se suas medidas partem de sua autoridade limitada, ou de sua latitude discricionária; desde porém que há reclamação contenciosa cumpre reconhecer se, com efeito, trata-se de um simples interesse ou de um direito" (KUGELMAS, Eduardo (organização e introdução). José Antônio Pimenta Bueno, Marquês de São Vicente. São Paulo: Ed. 34, 2002. p. 308-309).

${ }^{231}$ Em História Sincera da República, Leôncio Basbaum lembra a carta de Aristides Lobo ao Diário Popular sobre o conhecimento e a participação popular em sua Proclamação, o que de algum modo revela como nossa sociedade reage a estes episódios: “Aristides Logo, na célebre carta ao Diário Popular de São Paulo, datada de 18 de novembro, confessa que 'a colaboração civil foi quase nula' e que 'o povo assistiu àquilo bestializado, sem saber o que significava, julgando tratar-se de uma parada'. Era pois um movimento completamente alheio ao povo, foi típica e exclusivamente um levante militar. A população de nada sabia" (de 1889 a 1930, 6 ${ }^{a}$ edição, São Paulo: Alfa- Omega, p. 18). Sobre a Constituição Republicana, Basbaum escreve: "Embora não pareça, havia realmente uma Constituição republicana que, promulgada a 24 de fevereiro de 1891, durou formalmente até 24 de outubro de 1930. Era Constituição, disse Oliveira Viana ${ }^{1}$ 'nunca foi posta em prática'. Votada por uma Assembléia Constituinte que era, como vimos, um saco de gatos em matéria de concepções políticas e republicanas, não fora uma Constituição 'feita para durar'. Elaborada ao sabor das circunstâncias momentâneas, ela representava não o pensamento meditado e calculado de uma classe, mas as opiniões ocasionais e os interesses imediatos de uma constituinte heterogênea em que o que menos havia era consciência jurídica e o conhecimento da realidade nacional" (BASBAUM, Leôncio. História sincera da república. 6a ed. São Paulo: Alfa-Omega, 1997, p. 183)

${ }^{232}$ CAVALCANTI, Themístocles Brandão.TRATADO de Direito Administrativo. $3^{\mathrm{a}}$ edição. Volume I. Teoria Geral do Direito Administrativo - Atos e Contratos Administrativos - responsabilidade do Estado. Rio de Janeiro: Livraria Freitas Bastos, 1955. p. 33. 
Embora não tenha feito menção a nenhum julgado, para este autor, o “Tribunal de Contas foi, porém, no regime republicano, um dos melhores elementos da construção do nosso direito administrativo.

Embora dentro dos limites de sua competência, restrita na órbita administrativa, competência que deveria ter sido ampliada, mesmo com sacrifício de suas funções fiscalizadoras das contas, pôde aquêle Tribunal proferir importantes decisões que representam a melhor contribuição da jurisprudência administrativa no primeiro período da era republicana" 233.

Ruy Cirne Lima traz informações relevantes sobre a estrutura administrativa e o Direito Administrativo com a Proclamação da República. Com ela, suprime-se a jurisdição administrativa do Conselho de Estado; desaparece o Poder Moderador. "Larga e fecunda é a obra dos administradores republicanos. Eles empreendem e realizam a reconstrução do país, Adquire, por isso mesmo a Administração brasileira um sentido novo: flexibiliza-se, expande-se, move-se, vive. Não mais a contém, agora, os quadros rígidos do direito privado.

Mostram-se, entretanto, os nossos autores tardos em classificar-lhe os progresso sob a rubrica do Direito Administrativo. Escassa ou nenhuma é a atenção concedida a esse ramo do direito, como disciplina autônoma e sistematicamente organizada.

Reside a causa dessa indiferença pelo Direito Administrativo na própria base, sobre que se fez assentar o nosso direito público. Foram as instituições dos Estados Unidos da América e os princípios da common law tomados para fundamento do nosso regime incipiente (Dec. 848, de 11.10.1890).

Estava, porém, o fundamento em contradição com o regime. Neste se estabelecia constitucionalmente a partição do direito objetivo em direito civil, comercial, criminal e processual (art. 34, n. 23, da Constituição de 1891). Ora o common law, oposta aos statues, abrange, no conceito norte-americano, os princípios que regem assim de uma parte a justiça repressiva, como, de outra, a direção dos negócios públicos e, de outra ainda, a conservação do interesse privado, a regulamentação das instituições domésticas, e a aquisição, fiscalização e transferência da propriedade (Cândido de Oliveira Filho, Direito

233 CAVALCANTI, Themístocles Brandão.TRATADO de Direito Administrativo. $3^{\text {a }}$ edição. Volume I. Teoria Geral do Direito Administrativo - Atos e Contratos Administrativos - responsabilidade do Estado. Rio de Janeiro: Livraria Freitas Bastos, 1955. p. 37. 
Teórico e Direito Prático, Rio de Janeiro, 1936, n. 10, pp. 27 28); todo destarte todos os ramos da Ciência do Direito (idem, pp. 24 e ss).

O resultado dessa contradição é a incerteza das categorias jurídicas no nosso Direito Administrativo; é o desconhecimento de pessoas administrativas, fora da união, dos Estados e dos Municípios; é o desconhecimento dos limites do domínio público, além dos que lhe assinala a propriedade da união, dos estados ou dos Municípios/ é o desconhecimento da doutrina dos atos administrativos, acima das prescrições do direito privado.

Traço característico desse momento histórico é, destarte, o exotismo, mais político do que jurídico, do qual decorre, paradoxalmente, em contraste com o largo desenvolvimento material do Direito Administrativo, o desconhecimento formal deste ${ }^{\text {} 234}$.

Dividindo a evolução da Administração Federal no Brasil, em três períodos - desde a Independência até 1930, de 1930 até 1945, e de 1945 até dias correntes (a $1^{\text {a }}$ edição do livro foi editada em 1966) -, Guerreiros Ramos ${ }^{235}$ observou que no primeiro período, "a administração, além de suas funções normais, atendeu em especial à necessidade de absorver o excedente de mão-de-obra ao qual o incipiente sistema produtivo do País não podia dar ocupação (...) Funcionando nesse caráter, a administração exercia indiretamente um papel positivo, pois ao assegurar posição e função a significativo de contingente de pessoas letradas, evitava que elas fossem compelidas a atitudes subversivas, se lançadas ao desemprego. Ademais, contribuía para a formação de uma classe média, cuja participação não foi desprezível em nossa evolução econômica, política e cultural. O Brasil, nesse período, foi o 'país sem povo' de que falavam os cronistas estrangeiros que nos visitaram, como Saint-Hilaire e Louis Couty (...) Até 1930, o País era arquipélogo de mercados regionais, justapostos, mal articulados. Em tais condições, as

\footnotetext{
${ }^{234}$ LIMA, Ruy Cirne. Princípios de Direito Administrativo $7^{\mathrm{a}}$ ed., revista e reelaborada por Paulo Alberto Pasqualini. São Paulo: Malheiros, 2007. p. 64.

${ }^{235}$ RAMOS, Guerreiro. Administração e Contexto Brasileiro: esboço de uma teoria geral da administração. $2^{\mathrm{a}}$ ed. Rio de janeiro: Ed. da Fundação Getúlio Vargas, 1983. p. 344. Osvaldo Aranha Bandeira de Mello observa que "A preocupação científica do Direito Administrativo desde a queda da Monarquia aos tempos atuais divide-se em duas fases nítidas, como expressão de posições distintas do Estado. Pode-se mesmo falar em período da $1^{\text {a }}$ república, que vai de 1989 até a Revolução de 1930, e da $2^{\text {a }}$ República, dessa data em diante. Naquele o regime administrativo desenrolou sob a inspiração da Constituição de 1981, de caráter nitidamente liberal, individualista. Então, regulamentava a vida jurídica de um país organizado, sob o ponto de vista social, em moldes feudais e com economia predominantemente agrícola. Já, o regime administrativo após o movimento revolucionário de 1930, de caráter político, mas que deu início a uma transformação social e econômica da vida nacional e constitui o marco da nova República, teve alta expressão. Nessa época assiste-se a um país subdesenvolvido em busca de sua independência econômica, através da industrialização manufatureira. Substitui, então, a ordem constitucional vigente por outra, de feição socializante, de intervenção crescente na ordem social, em especial mediante o dirigismo econômico-financeiro da Nação" (MELLO, Osvaldo Aranha Bandeira de. Princípios Gerais de Direito Administrativo. $3^{\mathrm{a}}$ ed. $2^{\mathrm{a}}$ tiragem. São Paulo: Malheiros Editores, 2010, p. 142. Vol I).
} 
atividades administrativas tinham de ser muito singelas, não exigindo o seu exercício preparo muito especial do servidor. Dir-se-á que, para cumprir os seus deveres, bastava-lhe o conhecimento das leis, regulamentos e praxes. Eis porque se pode afirmar que, no período, predominava no trabalho administrativo o espírito jurídico-legal.

O caráter rudimentar da sociedade se refletiu na administração pública"

Afirmando ter havido profundas transformações em nossas instituições administrativas, Themístocles Brandão Cavalcanti registra que de 1930 "para cá vemos nascer entre nós o Direito Administrativo em sua concepção mais exata, pela aplicação de suas normas peculiares às relações internas dos serviços públicos e às do Estado com os particulares, quer o Estado se apresente como parte, quer com poder político e administrativo.

O Estatuto dos funcionários públicos, os Códigos de Água, de Minas, de Caça e Pesca, Florestal, são exemplos bem significativos de uma codificação parcial da disciplina que só se obtém em plena era de crescimento do direito codificado.

A estrutura reforçada do Poder Executivo, a ampliação do poder de polícia e de sua conceituação, a penetração mais profunda dos estudos sôbre organização do trabalho em geral e dos serviços públicos, em particular, uma vaga tendência para uma tecnocracia. Sinceramente ensaiada por alguns estudiosos, foram circunstâncias que influenciaram poderosamente para um novo surto das ciências administrativas.

Sofreu inicialmente o Direito Administrativo rude golpe pela incompreensão das relações da disciplina jurídica com a técnica da administração, incompreensão devida talvez à falta de exame dos fenômenos sociais, em sua generalidade e, talvez à improvisação de certos valores jovens ardorosos, mas apegados às soluções unilaterais, pragmáticas, movidos pela prevenção contra as velhas fórmulas jurídicas, ignorantes talvez de que a técnica jurídica também evolui, também se afirma como expressão das condições sociais e dos fenômenos econômicos e políticos.

Por outro lado também o Direito Administrativo se havia retardado, elaborando as suas doutrinas e evoluindo à margem do desenvolvimento técnico e dos novos sistemas de administração.

Êste mal-entendido obedece, entretanto, a uma conceituação superficial do fenômeno administrativo limitado aos seus aspectos práticos ou puramente científicos.

O problema do direito embora fundamentalmente ético, é eminentemente técnico $(\ldots)$ 
Que bases jurídicas seguras podem ter, efetivamente, certas concessões de serviços públicos sem estudos especializados, técnicos alheios à ciência do direito?

Como regular os processos de seleção, o regime de promoções ou de ingresso na função pública, sem estudos de ciências complementares (psicotécnica, medicina, etc)?

Há, portanto, em toda norma legal ou regulamentar, um conteúdo científico alheio ao direito, ao lado do seu conteúdo jurídico, que envolve a aplicação de regras de justiça e de moral, regras gerais e impessoais necessárias para a sua plena eficácia.

Ligados a certos problemas de construção legal existem também os de aplicação, processo, sistemas de interpretação, etc.

Por outro lado, todo o movimento tendente a substituir, por eliminação, os princípios jurídicos fundamentais por outros processos de pura técnica experimental, importará na deformação do problema e de suas soluções.

O problema é eminentemente jurídico, em sua acepção mais larga, e em tôrno da estrutura jurídica devem gravitar os outros elementos que contribuem para a vida do Estado.

Naturalmente que as concepções jurídica também evoluem, que a técnica jurídica também se renova e acompanha o ritmo da evolução científica e por isso não se deve exagerar o temor do atraso do direito sôbre os fatos, mas adaptá-los aos fatos, à realidade social" 236 .

Bem se observa a preocupação do administrativista Themístocles Brandão Cavalcanti com a realidade do Direito Administrativa de seu tempo. Em síntese, a levar por suas palavras: incipiente codificação parcial, descompasso entre a disciplina e as técnicas de administração, problemas de aplicação, processo e sistemas de interpretação no âmbito do Direito, e sua preocupação, quase que um apelo, para a necessidade de se

\footnotetext{
${ }^{236}$ CAVALCANTI, Themístocles Brandão.Tratado de Direito Administrativo, volume I, $3^{\text {a }}$ edição, Teoria Geral do Direito Administrativo - Atos e Contratos Administrativos - Responsabilidade do Estado, Rio de Janeiro: Livraria Freitas Bastos, 1955, p. 38-40. Guerreiro Ramos observa que "A partir de 1930, a administração pública é compelida a exercer funções que, ou eram residuais ou inexistiam em épocas anteriores. Três Ministérios foram criados na década de 30, o do Trabalho, Indústria e Comércio, o da Educação e Saúde e o da Auronáutica (...) Se algo se desejasse ressaltar para caracterizar este segundo período, indicaríamos o imperativo da eficiência. A administração pública começava perder aquele dissimulado caráter assistencial e ia ganhando foros de instrumentalidade do Governo, destinada á condução eficiente dos negócios públicos" (RAMOS, Alberto Guerreiro. Administração e Contexto Brasileiro: esboço de uma teoria geral da administração. $2^{\mathrm{a}}$ ed. Rio de janeiro: Ed. da Fundação Getúlio Vargas, 1983. p. 345).
} 
compreender o Direito Administrativo atuando em conjunto com outras ciências complementares (psicologia, medicina etc.) para o exercício da função pública.

Osvaldo Aranha Bandeira de Mello observa que de 1930 em diante, desenvolvem-se, destarte, as organizações administrativas. Surgem novas pessoas jurídicas públicas para a execução de serviços especificados, e como desdobramento das pessoas jurídicas públicas de natureza territorial, que cuidavam, segundo a esfera política, dos interesses gerais dos cidadãos que a integram. Cresce o corpo do funcionalismo e se dispõem em moldes mais racionais os direitos e deveres dessa profissão

Aumenta a atividade administrativa, que se distende em todos os setores, Além do asseguramento da ordem pública, através da ação negativa da polícia, ramifica-se na ingerência de todos os campos da vida social, na execução de obras públicas e prestação de serviços públicos, na preservação da saúde e higiene pública, na efetivação da educação e ensino publico, no desenvolvimento da economia pública e proteção do hipossuficiente, por meio da assistência e previdência social.

O Direito Administrativo, apesar de distinto do Direito Constitucional, sofreu o influxo deste último, e mesmo da teoria do Estado, no seu aspecto filosófico e sociológico (...)

Como ordenamento jurídico da atividade do Estado, na consecução de utilidade pública, de modo direto e imediato, se há de fazê-lo segundo concepção filosófica e sociológica do Estado e na conformidade com o Direito Constitucional, quanto a ação positiva daquele por esta disposta, ao organizá-lo estruturalmente, pondo em ação seu regime político e seu programa social" 237

A partir de 1945, ensina Guerreiros Ramos que "o sistema administrativo brasileiro entrara em nova fase. Como caracterizá-la? Tratava-se da fase em que se incorporava ao trabalho administrativo o critério ou a atitude de planificação, entendida a palavra no sentido sociológico, principalmente naquele em que emprega Karl Mannheim. No caso, a planificação é menos uma técnica do que etapa mesmo do desenvolvimento social. O conteúdo econômico da sociedade brasileira atingira tal complexidade, que os seus problemas permaneceram insolúveis, se e enquanto tratados isoladamente, isto é, se enquanto não fossem referidos à constelação de fatores que resulta. $\mathrm{O}$ que estava em causa, agora, era a funcionalidade mesma das instituições administrativas em relação às demandas da estrutura econômica e social do País, que vinha de constituir-se. A questão mesma da

${ }^{237}$ MELLO, Osvaldo Aranha Bandeira de. Princípios Gerais de Direito Administrativo. $3^{\mathrm{a}}$ ed. $2^{\mathrm{a}}$ tiragem. São Paulo: Malheiros Editores, 2010, p. 142-143. Vol I. 
eficiência nos serviços era subsidiária, em relação à questão do ajustamento desses serviços, em conjunto, à realidade econômica e social.

Como o problema administrativo do País não foi examinado sob o prisma da planificação, isto é, à luz da consciência de que todo o sistema administrativo anterior ou vigente, até mais ou menos 1945, tinha cumprido seu papel histórico e se tornara, portanto, obsoleto, foi sendo criado por uma série de tentativas e aproximações, ao lado do antigo, novo sistema, a fim de atender aos ditames da nova sociedade brasileira, notadamente naquele setor - o econômico - em que se faziam sentir de modo mais indisfarçável. A estrutura econômica e suas necessidades e suas necessidades passam a constituir o centro das indagações de sucessivos relatórios"238.

Na Constituição de 1934, salienta Ruy Cirne Lima que se define "o Ministério Público, situado entre o Executivo e o Judiciário, o Tribunal de Contas, entre o Legislativo e o executivo, e os conselhos Técnicos, entre a Administração e o povo, como órgãos de cooperação nas atividades governamentais.

Diversamente da Constituição de 1891, possui, entretanto, a Constituição de 1934 um largo conteúdo social - moral, religioso, econômico, cultural. Por essa direta comunicação com os elementos da vida social, desde logo se alcança a importância que adquire, no segundo estatuto republicano, o Direito Administrativo.

São numerosas as soluções de Direito Administrativo enunciadas no texto supremo. Um Tribunal de Direito Administrativo é instituído na organização federal.

A paciente investigação dos sabedores e a jurisprudência dos arestos haviam determinado já as feições inconfundíveis do Direito Administrativo Brasileiro. Na Constituição de 1934, designadamente, se lhe conferiu lugar à parte nos quadros do nosso direito positivo (art. 79, parágrafo único, n. 1)"239

A terceira Constituição republicana do Brasil, em 1937, segundo Ruy Cirne Lima, foi "expressão de um golpe de Estado". Nesse período houve notável codificação de nosso direito positivo. "São os regimes dessa natureza propícios ás codificações, as quais, à sua vez, se assemelham às revoluções e aos golpes de estado, pela reordenação inovadora que impõem ao direito positivo" 240 .

238 RAMOS, Alberto Guerreiro. Administração e Contexto Brasileiro: esboço de uma teoria geral da administração. $2^{a}$ ed. Rio de janeiro: Ed. da Fundação Getúlio Vargas, 1983. p. 346-347.

${ }^{239}$ LIMA, Ruy Cirne. Princípios de Direito Administrativo $7^{\mathrm{a}}$ ed., revista e reelaborada por Paulo Alberto Pasqualini. São Paulo: Malheiros, 2007. p. 64-65.

240 Idem, ibidem. p. 65. Observando que o Departamento Administrativo do Serviço Público - DASP -, estava previsto na Constituição de 1937, Guerreiro Ramos observou que ele "sobretudo durante o período em que foi seu presidente, o dr. Luiz Simões Lopes, tornou-se centro irradiador de influências renovadoras e, 
Prosseguindo, em relação à quarta Constituição republicana do país, em 1946, “combinaram-se elementos da Constituição de 1934 com elementos da Constituição de 1981, utilizados, estes como simplificação daqueles. A fisionomia do regime, salvo no que concerne á ordem econômica e social, aproxima-s, e inequivocamente, da de 1891",241.

Esta ordem constitucional "foi rompida pelo movimento revolucionário de 31 de março de 1964, em que as Forças armadas, juntamente com parte das forças políticas, destituíram o presidente da república e retiraram a legitimidade democrática da Constituição, que foi mantida por um Ato institucional. A esse primeiro Ato seguiram-se outros, com recesso temporário do Congresso, extinção de partidos políticos, tudo dentro do quadro da 'guerra fria' e do antagonismo entre o mundo capitalista e o mundo socialista, com as suas repercussões em nosso país" ${ }^{242}$.

Enfim, surge a quinta, e vigente, Constituição republicana do Brasil: agora com o desejo de construir um ambiente democrático para o exercício da função administrativa.

após terem sido criados os Departamento de Administração nos Ministérios, funcionou como peça mestra de um sistema racionalizador, no âmbito da administração geral do Poder Executivo Federal. Pode-se afirmar que, entre 1930 e 1945, ocorreu verdadeira revolução administrativa no Brasil, tal o porte das modificações de estrutura e de funcionamento que se verificaram em nosso serviço público federal" (RAMOS, Alberto Guerreiro. Administração e Contexto Brasileiro: esboço de uma teoria geral da administração. $2^{\mathrm{a}}$ ed. Rio de janeiro: Ed. da Fundação Getúlio Vargas, 1983. p. 345-346). Sobre o DASP, Edson de Oliveira Nunes escreveu: "O DASP era um organismo paradoxal, porque combinava insulamento burocrático com tentativas de institucionalização do universalismo de procedimentos. Criado para racionalizar a administração pública e o serviço público, o departamento preocupava-se com o universalismo de procedimentos em assuntos relacionados com a contratação e a promoção dos funcionários. Nesse aspecto o DASP representava a fração moderna dos administradores profissionais, das classes médias e dos militares, tornando-se um agente crucial para a modernização da administração pública. Embora jamais tenha completado sua missão, o DASP deu inúmeros passos positivos para a modernização do aparelho de estado e para a reforma administrativa" (NUNES, Edson de Oliveira. A gramática política no Brasil: clientelismo e insulamento burocrático, prefácio de Luiz Carlos Bresser Pereira, $4^{\mathrm{a}}$ edição - Rio de Janeiro: Garamond, 2010, p. 81).

${ }^{241}$ LIMA, Ruy Cirne. Princípios de Direito Administrativo $7^{\mathrm{a}}$ ed., revista e reelaborada por Paulo Alberto Pasqualini. São Paulo: Malheiros, 2007. p. 65-66.

${ }^{242}$ Idem, ibidem. p. 66. Guerreiro Ramos observa que já se cogitava, no Governo Castelo Branco, de uma ampla reforma da Administração Federal, e ela se consubstanciou no Decreto-lei n. 200, de 25 de fevereiro de 1967. Segundo este autor, na ocasião o ministro do Planejamento e Coordenação Geral apontara as seguintes deficiências na administração pública: centralização; execução direta; centralização de poderes na união, em detrimento dos governos locais.; leis minuciosas e regulamentares; falta de continuidade administrativa, falta de bons governos sucessivos; congestionamento da Presidência da república; falta de planejamento institucionalizado; regionalização e interiorização; inadequada e emperrada fiscalização dos dinheiros públicos; deterioração do sistema do mérito. Salientando que esta reforma não se restringiu ao aludido Decreto-lei e à legislação complementa, conduto, "nele se identifica como marco formal do processo". A reforma trouxe, "de novo, a discriminação de critérios normativos a ponto de garantir-lhe continuidade dentro de princípios que adotou, e que foram: planejamento, coordenação, descentralização, delegação de competência, controle (...) O enfoque básico da reforma administrativa foi a substituição da prioridade concentrada no meios de execução, própria das simples alterações de estrutura e regulamentos, pelas finalidades do governo" (RAMOS, Alberto Guerreiro. Administração e Contexto Brasileiro: esboço de uma teoria geral da administração. $2^{\mathrm{a}}$ ed. Rio de janeiro: Ed. da Fundação Getúlio Vargas, 1983. pp. 349350). 
Estas considerações sobre o Estado e da Administração Pública no Brasil (embora sem cunho exaustivo) tem condições de trazer algumas características interessantes para se compreender a relação entre o Estado, o Direito e a sociedade até então.

No período imperial a sociedade esteve à margem da proteção constitucional. Distinguido os interesses dos direitos; fazendo a separação entre poder executivo puro e poder administrativo (ou na expressão do marquês de São Vicente, entre poder administrativo e poder governamental - seu "duplo caráter") e, por conseguinte, distinguido a administração entre graciosa e contenciosa e, assim, estabelecendo os processos respectivos (gracioso e contencioso), o Estado - todo-poderoso, único a decidir e definir o interesse público; aquele que na expressão de Paulino Soares de Sousa 'personifica o interêsse público"243 - se apresenta substancialmente pessoal, intangível, impermeável, indiferente em relação ao cidadão, à sociedade.

No curso da história até os dias atuais, a despeito das conquistas de cidadania, percebe-se que o Estado - sempre sobre o ponto de vista do governo federal -, sem esquecer os contratempos de modificação de regimes políticos, teve como preocupação maior uma visão unilateral de criar uma infraestrutura ao país a partir do governo federal e, como consequência disso criar, reposicionar a Administração pública no âmbito federal, sem maiores preocupações com a estrutura administrativa do país nos níveis estaduais e municipais.

De qualquer maneira, a despeito de conquistas de cidadania, a sociedade definitivamente sempre este em segundo plano. O Estado brasileiro também no curso desta sua fase republicana se portou como o único capaz de decidir e estabelecer o que deveria ser o destino do país. Sua Administração Pública, a reboque, sempre serviu aos interesses

243 URUGUAI, Visconde de. Ensaio sôbre o Direito Administrativo. Themístocles Brandão Cavalcanti (apres.). Rio de Janeiro: Serviço de Documentação do Ministério da Justiça e Negócios Interiores, 1960. p. 61. FAORO, Raymundo. Os donos do poder: formação do patronato político brasileiro. $3^{\mathrm{a}}$ ed. rev. São Paulo: Globo, 2001., no Capítulo X, O sistema Político do Segundo Reinado, no item 4, O estamento burocrático, faz um registro que se mostra pertinente, mutatis mutandis, a indicar que o espírito soberano não desapareceu ainda em nosso dias: "Uma voz, inflamada de protesto, dirá a seus contemporâneos, há um século: $\{\ldots\}$ os erros administrativos e econômicos que afligem o império, não são exclusivamente filhos de tal ou tal indivíduo que há subido ao poder, de tal ou tal partido que há governando: não; constituem um sistema seguido, compacto, invariável. Eles procedem todos de u, princípio político afetado de raquitismo, de uma ideia geradora e fundamental: a onipotência do estado, e no Estado a máquina central, e nesta máquina certas e determinadas rodas que imprimem movimento ao grande todo" (p. 445). Logo adiante, completa: "O governo tudo sabe, administra e provê. Ele faz a opinião, distribui a riqueza e qualifica os opulentos. $\mathrm{O}$ súdito, turvado com a rocha que lhe rouba o sol e as iniciativas, tudo espera da administração pública, nas suas dificuldades grandes e pequenas, confiando, nas horas de agonia, no milagre sápido das câmaras do paço ou dos ministérios. Esse perigoso complexo psicológico inibe, há séculos, o povo, certo de que o Estado não é ele, mas uma entidade maior, abstrata e soberana" . (FAORO, Raymundo. Os donos do poder: formação do patronato político brasileiro. $3^{\mathrm{a}}$ ed. rev. São Paulo: Globo, 2001. p. 451). 
deste tipo de Estado e de governo. Mantendo a sociedade longe dos "negócios públicos", o Estado e sua Administração Pública foram decisivos para a construção de uma débil consciência republicana e democrática de seu povo.

\section{VII - UM CONCEITO DO PRINCÍPIO DE IMPESSOALIDADE}

\subsection{Considerações iniciais: a noção de Formalismo}

O Brasil é um país em transição em relação a sua orientação política: da monarquia à república e, mais recentemente, de uma experiência de ditadura para um período atual de democracia. Embora esse não seja o objeto deste trabalho, mostram-se pertinentes as reflexões de Fred W. Riggs, em torno dos problemas administrativos, trazidas pelo sociólogo Alberto Guerreiro Ramos ${ }^{244}$, segundo aquele, típicos de sociedades em transição.

Para estudar estas sociedades, o autor norte-americano propõe uma escala de três modelos ecológicos: o concentrado, o prismático e o difratado.

Interessa-nos, tendo em conta o tema deste trabalho, o modelo cujas características parecem compatíveis com a realidade do Brasil: o modelo prismático, que é um ponto médio entre os dois outros modelos.

Observa o sociólogo brasileiro que, para explicar os modelos, Riggs emprega o critério do formalismo ${ }^{245}$, que para este, segundo Guerreiro Ramos ${ }^{246}$, é “a

\footnotetext{
244 Apud RAMOS, Alberto Guerreiro. Administração e Contexto Brasileiro: esboço de uma teoria geral da administração. $2^{\text {a }}$ ed. Rio de janeiro: Ed. da Fundação Getúlio Vargas, 1983.

245 "A fim de caracterizar os diferentes modelos de sociedade, Riggs utiliza basicamente o critério do formalismo, embora recorra também a dois outros, o de heterogeneidade e o de superposição (...) A sociedade prismática apresenta alto grau de heterogeneidade, uma vez que nela coexistem o antigo e o moderno, o atrasado e o avançado, o velho e o novo. Esta heterogeneidade se exprime materialmente, entre outras, sob a forma de mistura de elementos tecnológicos, modernos e antigos, urbanos e rurais (...) Também nas condutas humanas se registram idênticas disparidades: costumes, hábitos, atitudes e estilos de alta sofisticação (...) ao lado de comportamentos tradicionalistas (...) Na sociedade prismática cada pessoa é, de ordinário, interiormente dividida pela assimilação de opostos critérios de avaliação e ação. Diversamente, tanto a sociedade concentrada quanto a difratada apresentam alto grau de homogeneidade, no sentido de que práticas e sistemas aí vigentes são mais coerentes do que nas sociedades prismáticas. A superposição consiste no exercício cumulativo de funções diferentes por uma mesma unidade social e assim verifica-se, por exemplo, onde funções administrativas, políticas, econômicas, educacionais não são, na prática, exercidas por agências distintas e segundo critérios específicos. Numa sociedade concentrada, isso acontece,
} 
discrepância entre a conduta concreta e a norma prescrita que se supõe regulá-la. Registrase ali onde o comportamento efetivo das pessoas não observa as normas estabelecidas que lhe correspondem, sem que disso advenham sanções para os infratores. Essa incongruência, segundo Riggs, típica no que concerne às sociedades prismáticas, é mínima nas sociedades concentradas e difratadas, nas quais os comportamentos, por suposto, soem ser altamente realísticos, embora em nenhuma delas esteja isenta de formalismo. O realismo opõe-se assim ao formalismo, do ponto de vista conceitual. Textualmente, diz Riggs. 'O formalismo (grifado no original - G.R.) corresponde ao grau de discrepância entre o prescritivo e o descritivo, entre o poder formal e o poder efetivo, entre a impressão que nos é dada pela constituição, pelas leis e regulamentos, organogramas e estatísticas, e os fatos e práticas reais do governo e da sociedade. Quanto maior a discrepância entre o formal e o efetivo, mais formalístico o sistema".

Logo, em seguida, para ilustrar esta noção de formalismo, Guerreiro Ramos faz menção a uma imagem bastante interessante criada por Riggs que parece se aplicar ao princípio de impessoalidade. Diz Guerreiro Ramos: "Eis por exemplo, ilustração do formalismo proposta por Fred Riggs. Se alguém procurar uma casa, em cidade desconhecida, seguindo um mapa precariamente desenhado, poderá ser induzido a escolher ruas que, ao invés de o conduzirem ao lugar desejado, ao contrário, dele o desviará. Porque não representa fielmente a realidade, tal mapa poderá se chamado de formalístico. Analogamente, o conhecimento objetivo de uma sociedade prismática jamais pode ser obtido a partir de estruturas normativas legais. $\mathrm{O}$ observador que assim proceder encontrarse-ia em face da efetiva realidade social, como aquele que utiliza um mapa precário a fim de procurar uma rua ou residência".

Interessante, ainda, é o objetivo que se pretende com o formalismo: "Riggs sublinha a dominância do formalismo nas sociedades prismáticas, com o objetivo, implícito ou explícito, de encaminhar o ponto de vista da ecologia da administração. Esse ponto de vista representa um esforço de superação de toda teoria e prática administrativas que admitam a existência de normas, regras e fórmulas, em resumo, estruturas intrinsecamente válidas, e assim suscetíveis de produzir resultados positivos em quaisquer

necessariamente, por imperativo estrutural. Na sociedade difratada, a superposição é escassa, a cada estrutura devendo corresponder uma função. $\mathrm{Na}$ sociedade prismática, ainda que as funções sejam formalmente atribuídas a distintas unidades sociais, na prática, critérios familísticos interferem na administração, a economia é condicionada a fatores não econômicos, a política ultrapassa o que se presumiria ser o seu domínio próprio" (RAMOS, Alberto Guerreiro. Administração e Contexto Brasileiro: esboço de uma teoria geral da administração. $2^{\mathrm{a}}$ ed. Rio de janeiro: Ed. da Fundação Getúlio Vargas, 1983. p. 250-252).

${ }^{246}$ Idem, ibidem. p. 252 e 254. 
sociedades, independentemente da especificidade histórica das mesmas. (...) A sistemática atenção que estudiosos estrangeiros vêm dando às funções e estruturas em sociedades diferentes, os torna cada vez mais sensíveis aos determinantes ecológicos dos métodos e processo do trabalho administrativo. Diz Riggs: ‘... nas sociedades em transição um alto grau de formalismo, resultante da superposição de instituições e de grande heterogeneidade social, acarreta aguda incongruência entre a instituição formalmente prescrita e o comportamento informal e efetivo. Sob tais circunstâncias, a análise institucional ou estrutural conduz a resultados desapontadores. O que podia esperar-se de particular sistema administrativo ou de um esquema organizacional deixa de ocorrer".

Naquilo que diz respeito ao objeto deste trabalho, o modo de agir da Administração Pública no Brasil tem gerado discrepância entre aquilo que a Constituição da República impõe a ela e aquilo que efetivamente é, de modo geral, realizado. O agente público tem o dever de apresentar à sociedade o "mapa" do seu agir administrativo. E nesse contexto pode-se dizer que o princípio de impessoalidade é uma resposta ao formalismo $^{247}$.

7. 2. O princípio de impessoalidade, nos termos do art. 37, da Constituição de 1988

\subsubsection{Um princípio constitucional}

\footnotetext{
247 Anote-se, a título de registro, que Guerreiro Ramos compreende o formalismo, a partir de Riggs, mas registra, que sua tese fundamental é a de que "o formalismo não é uma característica bizarra, traço de patologia social nas sociedades prismáticas, mas um fato normal e regular, que reflete a estratégia global dessas sociedades, no sentido de superar a fase em que se encontram. Em outras palavras, o formalismo nas sociedades prismáticas é um estratégia de mudança social, imposta pelo caráter dual de sua formação histórica e pelo modo particular como se articula com o resto do mundo." E observa, ainda, que "Todo o nosso raciocínio é fundado na observação das particularidades do processo-histórico-social do Brasil” (p. 6). Mais adiante o sociólogo brasileiro, no item "O formalismo e a sociologia do jeito", observa que o formalismo dá origem àquilo que se denomina o "jeitinho" brasileiro: "abramos um parêntese, onde possam caber algumas considerações sobre o 'jeito', ou seja, o genuíno processo brasileiro de solver dificuldades, a despeito do conteúdo das normas, códigos e leis. É exatamente o formalismo que acarreta a prática do 'jeito'. Em si mesmo, o formalismo é, como temos demonstrado, modalidade de estratégia. É uma estratégia primária. O ‘jeito’ é uma estratégia de segundo grau, isto é, suscitada pelo formalismo (...) O 'jeito’ é, no Brasil, processo nativo, criollo, de contornar uma dificuldade a despeito da lei e até mesmo contra ela. É, como observa o economista Roberto Campos, 'condição de sobrevivência do indivíduo e de preservação do corpo social', 'dentro do formalismo', em sociedades onde as leis são 'textos fora do contexto', construções teóricas que não nasceram do costume', 'formas transplantadas e importadas de além-mar sem relevância para as possibilidades econômicas de nosso ambiente"” (RAMOS, Alberto Guerreiro. Administração $e$ Contexto Brasileiro: esboço de uma teoria geral da administração. $2^{\mathrm{a}}$ ed. Rio de janeiro: Ed. da Fundação Getúlio Vargas, 1983. p. 287-288).
} 
Embora não seja objeto deste trabalho discorrer sobre as distinções entre princípios e regras, parte-se da premissa de que, a despeito de entendimento diverso ${ }^{248}$, o princípio de impessoalidade é um princípio. Ademais, não se confunde com regra ${ }^{249}$.

A Constituição adotou um sistema de princípios e regras. Ela não pressupõe uma disciplina legislativa exaustiva e completa, tampouco a indeterminação, a inexistência de regras precisas e a coexistências de princípios conflitantes. Optou-se por um sistema normativo aberto de regras e princípios ${ }^{250}$.

${ }^{248}$ O professor Luiz Streck, no item "De como princípios não são categorias ou enunciados assertóricos ou de como o mundo prático se institucionaliza no direito do Estado Democrático" e subitem "De como não é possível uma "livre nominação dos princípios", argumenta, depois de discorrer sobre o princípio de moralidade, que "o problema não fica apenas no contexto da moralidade. Veja-se, igualmente, o problema do princípio da impessoalidade. Não é algo inerente à moderna ideia de Estado que os atos dos agentes públicos sejam permeados pelo manto da impessoalidade? Não é isso algo essencial ao Estado de Direito que, se ocorresse o contrário - a pessoalidade -, não teríamos que afirmar que isso seria uma desvirtuação do Estado para uma forma pré-moderna de organização burocrática? Porque, então, insistir em chamar a impessoalidade de um princípio?". Aqui, anote-se, o professor parece compreender a impessoalidade a partir da noção de lei. (STRECK, Lênio Luiz. Verdade e Consenso: constituição, hermenêutica e teorias discursivas. , $4^{\mathrm{a}}$ ed. São Paulo: Saraiva, 2011. p. 582-583).

${ }^{249}$ A expressão "regra da impessoalidade" é utilizada por José Afonso da Silva. Mais precisamente nos seguintes termos: "O princípio ou regra da impessoalidade da Administração Pública significa que os atos e provimentos administrativos são imputáveis não ao funcionário que os pratica mas ao órgão ou entidade administrativa em nome da qual age o funcionário (...) É que a 'primeira regra do estilo administrativo é a objetividade', que está em estreita relação com a impessoalidades" (SILVA, José Afonso da. Curso de Direito Constitucional Positivo. $22^{\mathrm{a}}$ ed. revista e atualizada nos termos da Reforma Constitucional - até a Emenda Constitucional n. 39, de 19.12.2002. Local: Editora, ano. p. 647). Sobre um conceito de regra, interessante o de Humberto Ávila: "As regras são normas imediatamente descritivas, primariamente retrospectivas e com pretensões de decidibilidade e abrangência, para cuja aplicação se exige a avaliação da correspondência, sempre centrada na finalidade que lhes dá suporte ou nos princípios que lhes são axiologicamente sobrejacentes, entre a construção conceitual da descrição normativa e a construção conceitual dos fatos" (Teoria dos princípios: da definição à aplicação dos princípios jurídicos, $6^{\text {a }}$ edição revista e ampliada, São Paulo: Malheiros, 2006, p. 78). Em sentido contrário, não distinguido os princípios das regras, Eros Roberto Grau (GRAU, Eros Roberto. Porque tenho medo dos juízes (a interpretação/aplicação do direito e dos princípios). $6^{a}$ edição refundida do ensaio e discurso sobre a interpretação/aplicação do direito. São Paulo: Malheiros, 2013. p. 104-114). Neste mesmo livro, o autor alerta: "Pouco resta, na visão que hoje tenho do fenômeno jurídico, do quanto escrevi no Ensaio e discurso sobre a interpretação/aplicação do direito a respeito dos princípios, em suas várias e variadas versões, Eis, em síntese, o que agora desejo sustentar: os princípios são regras (...) O que desejo enfaticamente afirmar é a não transcendência dos chamados princípios de um determinado direito. Insisto em que me refiro a princípios de direito positivo, que, em verdade, são regras. Princípios que não necessitam de 'positivação', visto serem positivos, é uma tolice imaginar que o juiz, o jurista, o doutrinador, possa ser autor de alquimia de transformar algo exatamente no que esse algo sempre fora (...) fato é que em cada ordenamento jurídico subjazem regras que chamamos princípios. Cuida-se de 'princípios' desse direito, em verdade regras que, embora não enunciadas em texto escrito, nesse ordenamento estão contempladas, em estado de latência" (pp. 98-100).

${ }^{250}$ A compreensão deste sistema, que Canotilho chamou de "sistema jurídico do Estado de direito português", se mostra aplicável ao nosso sistema: "(1) é sistema jurídico porque é um sistema dinâmico de normas; (2) é um sistema aberto porque tem estrutura dialógica (Caliess), traduzida na disponibilidade e $<<$ capacidade de aprendizagem〉> das normas constitucionais para captarem a mudança da realidade e estarem abertas às concepções cambiantes da <<verdade〉> e da <<justiça〉>; (3) é um sistema normativo, porque a estruturação das expectativas referentes a valores, programas, funções e pessoas, é feita através de normas ${ }^{1}$; (4) é um sistema de regras e de princípios, pois as normas do sistema tanto podem revelar-se sob a forma de princípios como sob a sua forma de regras" ". Nas notas de rodapé, Canotilho faz menção a Alexy e Luhmann, respectivamente (CANOTILHO, J. J. Gomes. Direito Constitucional e Teoria da Constituição. $7^{\text {a }}$ edição. Coimbra: Edições Almedina, 2003. p. 1159). 
Na lição de Gomes Canotilho ${ }^{251}$, "Qualquer sistema jurídico carece de regras jurídicas (...) Contudo, o sistema jurídico necessita de princípios (ou valores que eles exprimem) como os da liberdade, igualdade, dignidade, democracia, Estado de direito".

No rol destes princípios, bem podemos incluir o princípio de impessoalidade, o art. 37, caput, da Constituição da República.

Relativamente aos princípios, o constitucionalista português acrescenta que "Em virtude de sua <referência » a valores ou da sua relevância ou proximidade axiológica (da <<justiça〉>, da <<ideia de direito〉>, dos <<fins de uma comunidade〉>), os princípios têm uma função normogenética e uma função sistêmica: são o fundamento de regras jurídicas e têm idoneidade irradiante que lhes permite «ligar»> ou cimentar objectivamente todo o sistema constitucional. Compreende-se, assim, que as <<regras $>$ e <princípios〉>, para serem activamente operantes, necessitam de procedimentos e processos que lhes dêem operacionalidade prática (Alexy: Regel/Prinzipien/ProzedurModell des Rechtssystems): o direito constitucional é um sistema aberto de normas e princípios que, através de processos judiciais, procedimentos legislativos e administrativos, iniciativas dos cidadãos, passa de uma law in the books para uma law in action para uma $<$ living constitution $>$.

Esta perspectiva teorético-jurídica do «sistema constitucional $\gg$, tendencialmente <principialista〉, é de particular importância, não só porque fornece suportes rigorosos para solucionar certos problemas metódicos (...), mas também porque permite respirar, legitimar, enraizar e caminhar o próprio sistema. A respiração obtém-se através da <textura aberta〉 dos princípios; a legitimidade entrevê-se na ideia de os princípios consagrarem valores (liberdade, democracia, dignidade) fundamentadores da ordem jurídica e disporem de capacidade deontológica de justificação; o enraizamento prescruta-se na referência sociológica dos princípios a valores, programas, funções e pessoas; a capacidade de caminhar obtém-se através de instrumentos processuais e procedimentos adequados, possibilitadores da concretização, densificações e realização prática (política, administrativa, judicial) das mensagens normativas da constituição”.

${ }^{251}$ CANOTILHO, J. J. Gomes. Direito Constitucional e Teoria da Constituição. $7^{\mathrm{a}}$ edição. Coimbra: Edições Almedina, 2003. pp. 1162-1163. 
A propósito, o princípio de impessoalidade bem se amolda à esta perspectiva teorético-jurídica de permitir respirar, legitimar, enraizar e caminhar o próprio sistema, apontada por Gomes Canotilho.

Sobre princípio, pertinente a lição de Humberto Ávila ${ }^{252}$.

“Os princípios são normas imediatamente finalísticas, primariamente prospectivas e com pretensão de complementariedade e de parcialidade, para cuja aplicação se demanda uma avaliação da correlação entre o estado de coisas a ser promovido e os efeitos decorrentes da conduta havida como necessária à sua promoção.

Como se vê, os princípios são normas imediatamente finalísticas. Eles estabelecem um fim a ser atingido. Como bem define Ota Weinberger, um fim é uma idéia que exprime uma orientação prática. Elemento constitutivo do fim é a fixação de um conteúdo como pretendido. Essa explicação só consegue ser compreendida com referência à função pragmática dos fins: eles representam uma função diretiva (richtungsgebende Funktion) para a determinação da conduta. Objetivo do fim é o conteúdo desejado. Esses, por sua vez, podem ser o alcance de uma situação terminal (viajar até algum lugar), a realização de uma situação ou estado (garantir previsibilidades), a perseguição de uma situação contínua (preservar o bem-estar das pessoas) ou a persecução de um processo demorado (aprender o idioma Alemão). O fim não precisa, necessariamente, representar um ponto final qualquer (Endzustand), mas apenas um conteúdo desejado. Daí se dizer que o fim estabelece um estado ideal de coisas a ser atingido, como forma geral para enquadrar os vários conteúdos de um fim. A instituição do fim é ponto de partida a procura dos meios. Os meios podem ser definidos como condições (objetos, situações) que causam a promoção gradual do conteúdo do fim. Por isso a ideia de que os meios e os fins são conceitos correlatos ${ }^{116,}$.

Utilizando-se ainda da lição de Gomes Canotilho ${ }^{253}$, pode-se dizer que o princípio de impessoalidade, na ordem constitucional vigente no Brasil, como princípio específico da Administração Pública, tem como seus princípios constitucionais estruturantes (sem pretensão de exaustividade): o princípio do Estado de Direito (CR, art. $1^{\circ}$ ), o princípio republicano (art. $1^{\circ}$ ), o princípio democrático (art. $1^{\circ}$, caput, parágrafo único), o princípio da inafastabilidade de jurisdição (CR, art. $5^{\circ}$, inc. XXXV), o princípio

\footnotetext{
${ }^{252}$ ÁVILA, Humberto. Teoria dos princípios: da definição à aplicação dos princípios jurídicos, $6^{\text {a }}$ ed. revista e ampliada, São Paulo: Malheiros, 2006, pp. 78-79. A nota de rodapé 116 traz: Ota Weinberger, Rechtslogik, $2^{\mathrm{a}}$ ed., p. 283.

${ }^{253}$ CANOTILHO, J. J. Gomes. Direito Constitucional e Teoria da Constituição. $7^{\mathrm{a}}$ edição. Coimbra: Edições Almedina, 2003. p. 1173.
} 
da dignidade da pessoa humana (CR, art. $1^{\circ}$, inc. III) e aquele que se poderia denominar princípio de construção social (CR, art. $\left.3^{\circ}\right)$.

Enfim, o princípio existe: art. 37, caput, da Constituição da República!

O princípio surge, enfim, tendo em vista a forma de agir da Administração Pública no curso da história e do desenvolvimento do Direito Administrativo no Brasil: a Sociedade não era preocupação do Estado e as categorias jurídicas existentes (substanciais e instrumentais, além da referida anomia) estavam a serviço dos donos do poder, daqueles que, mesmo de plantão, ocupavam o poder.

$\mathrm{O}$ princípio surge como instrumental adequado à nova ordem constitucional substancial a ser continuamente construída: rica em direitos fundamentais.

\section{2.2. O princípio existe e é um princípio instrumental}

Diogo de Figueiredo Moreira Neto ${ }^{254}$ estabelece uma classificação teórica entre princípios em que o critério de finalidade é utilizado para distingui-los.

O autor divide os princípios em substantivos e instrumentais.

Pelo que se infere da doutrina examinada neste trabalho ${ }^{255}$ o princípio de impessoalidade seria classificado como um princípio substantivo. Esta não é, contudo, a classificação que se mostra mais adequada ${ }^{256}$. Insistir nisso parece revelar mais um descompasso do Direito Administrativo ${ }^{257}$.

\footnotetext{
${ }^{254}$ MOREIRA NETO, Diogo de Figueiredo. Curso de Direito Administrativo: parte introdutória, parte geral e parte especial. Rio de Janeiro: Forense, 2009. p. 81. Conceituando o que seriam os princípios instrumentais, o professor afirma que eles, que também são chamados de princípios secundários, são aqueles que "contém uma opção formal destinada a melhor aplicar e garantir a aplicação dos princípios substantivos (...) o que afirma a processualidade". Saliente-se que o autor, por exemplo, inclui o princípio de dignidade da pessoa humana como um princípio substantivo, e o princípio de publicidade, como um princípio instrumental.

${ }^{255}$ Deve-se, contudo, registrar que os professores Odete Medauar e Marçal Justen Filho, embora não associam o princípio de impessoalidade com a processualidade, acabam por mencionar, quando escrevem sobre o princípio, sobre processualidade e procedimentalização, respectivamente. Registre-se, ainda, que, embora na tenha conceituado o princípio de impessoalidade, Demian Guedes chega a associá-lo ao processo por intermédio da imparcialidade e objetividade.

${ }^{256}$ Compreender o princípio de impessoalidade como um princípio substantivo é-lhe conferir o adjetivo de simbólico, na lição de Marcelo Neves, e, por conseguinte, alimentar também uma Constituição simbólica: "a questão refere-se à discrepância entre a função hipertroficamente simbólica e a insuficiente concreção jurídica de diplomas constitucionais (...) Por um lado, pressupõe a distinção entre texto e norma constitucional; por outro, procura-se analisar os efeitos sociais da legislação constitucional normativamente ineficaz (...) a constituição simbólica é caracterizada como um problema típico da modernidade periférica: a convivência de supercomplexidade social com falta de autonomia operacional do sistema jurídico (...) Tanto a dogmática jurídica quando a sociologia do direito dominantes, orientados pela experiência constitucional dos Estados democráticos europeus e norte-americanos, partem do seguinte pressuposto: há uma forte contradição entre direito e realidade constitucionais nos países 'subdesenvolvidos'. A rigor, assim entendo, a questão diz respeito à falta de normatividade jurídica do texto constitucional como fórmula democrática: a parte disto não se desenvolve suficientemente um processo concretizador de construção do direito constitucional; mas, ao mesmo tempo, a linguagem constitucional desempenha relevante papel político-
} 
O princípio de impessoalidade é um princípio instrumental, adjetivo. Ele permite qualificar duplamente a atuação administrativa: exigindo que se indiquem suas qualidades e assim permitindo que estas sejam submetidas a um juízo de qualificação, a uma razão jurídica crítica, na expressão de Alejandro Nieto.

Note-se que o princípio não é sinônimo de motivação. Esta é apenas uma parte do processo. É como se confundíssemos, por exemplo, a motivação do juiz no dispositivo da sentença com toda a atividade processual desenvolvida.

O princípio encaminha a atividade administrativa para uma processualidade única ${ }^{258}$ e integral. Algo como uma aproximação do processo judicial, uma processualidade estatal.

\subsubsection{Um conceito do princípio de impessoalidade ${ }^{259}$}

simbólico, também com amplas implicações na esfera jurídica" (NEVES, Marcelo. A constitucionalização simbólica. $3^{\mathrm{a}}$ ed. São Paulo: WFW Martins Fontes, 2011. pp. 1-3).

${ }^{257}$ Em $O$ Direito Administrativo do espetáculo, Marçal Justem Filho observa que "O percurso do Direito Administrativo reflete a transição do autoritarismo para a democracia. Os controles à atividade administrativa do Estado são cada vez mais amplos (...) a permeabilização do Direito Administrativo pelo Direito Constitucional conduz à correspondente revisão das estruturas clássicas da disciplina (...) Com algum exagero, pode-se utilizar a expressão 'Direito Administrativo do espetáculo' para qualificar o estado de cosias vigente. Indica a proliferação de institutos e interpretações deslocadas da realidade, vinculados à produção de um cenário imaginário e destinado a produzir o entretenimento dos indivíduos antes do que a efetiva implantação de valores fundamentais" (JUSTEN FILHO, Marçal. Direito Administrativo e seus novos paradigmas. In ARAGÃO, Alexandre Santos de; MARQUES NETO, Floriano de Azevedo (coords).

Belo Horizonte: Fórum, 2008. pp. 65-68).

${ }^{258}$ Aqui a questão lembrou-me a Administração Paralela apontada por Agustín A. Gordillo (GORDILLO, Agustín. La administración paralela. Madrid: Cuadernos Civitas, 2011). Diz este autor que "A insegurança do administrado frente à administração assume às vezes formas insuspeitas no plano teórico, mas dotadas de suficiente realidade no plano prático como para merecer algum comentário. Se trata da insegurança não apenas frente às normas jurídicas formais, mas também frente ás normas jurídicas e procedimentos que regem na prática, mas que não estão estabelecidos em nenhuma norma, o que inclusive contraria as expressas normas vigentes: o particular que não esteja habituado em tratar com a administração se desorienta em maior medida ainda, então atina sempre em escolher o método adequado de comportamento a seguir frente a tais circunstâncias. Existe assim um procedimento administrativo paralelo ao formal, como também uma organização administrativa informal que nem sempre coincide com a que o organograma indica" (p. 21-22).

${ }^{259}$ Adotou-se, neste trabalho, a expressão princípio de impessoalidade porque a expressão princípio $d a$ impessoalidade modifica o sentido do princípio constitucional. Naquele, a expressão de impessoalidade aparece como adjetivo, significando que se trata do princípio de uma determinada impessoalidade (não de qualquer impessoalidade) que qualifica/predica o substantivo princípio, conferindo-lhe um modo específico de agir (é pensar um princípio particular no seio do universal, indicando, com isso, a existência de uma finalidade; um princípio de ação, no caso, da Administração Pública); neste, ao contrário, o termo entremeia dois substantivos (princípio e impessoalidade) e traz a ideia de um princípio que pertence à generalidade da impessoalidade (um princípio referencial, que se refere à generalidade da impessoalidade, sem qualquer pretensão finalística, de ação). A propósito, expressões como Estado de Direito e ato de autoridade não teriam significados distintos das expressões Estado $d o$ Direito e ato $d a$ autoridade? Cremos que sim. A expressão Estado de Direito significa que o Estado que produz as leis também se submete a elas, diversamente da outra expressão em que Estado, embora as produza, pode escapar à sua incidência. Como exemplo de um Estado do Direito, pode-se citar o Estado Brasileiro do Império, em que a "chave de toda a organisação Política" (CPIB, art. 98) estava na figura do Poder Moderador; ou melhor, na pessoa do imperador, que era "inviolável, e Sagrada. Elle não está sujeito a responsabilidade alguma" (CPBI, art. 99). No caso da expressão ato de autoridade, aqui a lição é de José Cretella Júnior: a primeira expressão "designa 
Na República Federativa do Brasil, hoje, não se concebe juridicamente o exercício da função administrativa ${ }^{260}$ fora da impessoalidade.

A lei, sozinha, não é suficiente para regular a vida em sociedade ${ }^{261}$. O art. 37, caput, é um exemplo de que esta é mesmo uma realidade inexorável.

De forma singela, pode-se dizer que quando um agente público administrativo descumpre uma regra legal, ele, em tese, poderá ofender o princípio de legalidade. Quando ele pratica um "ato imoral", ele poderá ofender o princípio de moralidade. Quando ele, descompromissado, por exemplo, com o custo-benefício da decisão que tenha de tomar, e pratica o ato administrativo mesmo assim, ele poderá vir a ofender o princípio de eficiência.

Outros inúmeros exemplos poderiam ser mencionados. Quando o agente público administrativo favorece, indevidamente, um parente ou amigo ou terceiro, ou ainda, se autopromove na publicidade de seus atos públicos (v.g., na hipótese do art. 37,

as operações materiais", enquanto que a outra expressão "designa toda a espécie de ato cuja fonte seja a Administração" (CRETELLA JÚNIOR, J. Curso de Direito Administrativo de acordo com a Constituição de 1998. $11^{\mathrm{a}}$ ed. revista e atualizada, Rio de Janeiro: Forense, 1991. p. 189). Enfim, múltiplos exemplos poderiam ser citados, cuja modificação das preposições de e $d a$ modificariam o sentido das expressões: homem de palavra, homem da palavra, razão de Estado, razão do Estado, princípio de vida, princípio da vida etc. No mais, não parece sem razão que a Constituição da República de 1988 tenha adotado, no art. 37, caput, o termo princípio de impessoalidade. Raciocínio semelhante poder-se-ia fazer ao princípio de legalidade, salientando-se que em relação a ele o professor José Cretella Júnior usa indistintamente as expressões: "princípio da legalidade ou de legalidade" (CRETELLA JÚNIOR, J. Tratado de direito Administrativo: teoria do direito administrativo. $2^{\mathrm{a}}$ ed. atualizada. Rio de Janeiro: Forense, 2002. p. 38. v.1).

${ }^{260}$ Pertinente, aqui, a lição de Egon Bockmann Moreira: "frente ao direito processual o termo 'procedimento' jamais se prestou a designar, em sentido estrito, uma relação jurídica. Essa função é exercida com exclusividade pela palavra 'processo', que designa vínculo entre os sujeitos envolvidos na relação jurídicoprocessual. Não nos parece possível atingir outra máxima no âmbito do direito administrativo (...) Transposta a noção jurídica genérica dos termos 'processo', 'procedimento' e 'relação jurídica', resta questionar sua aplicabilidade ao direito administrativo (...) a atividade administrativa do estado pode ser vislumbrada sob dois ângulos: aquele da 'função administrativa' e o da 'relação administrativa'. Tertium non datur: inexiste terceira espécie de atividade estatal, que pudesse albergar atividades diferenciadas, extrafunção e/ou extrarelação administrativa. Mais do que isso, o conceito de 'função administrativa' é gênero, que alberga a 'relação jurídica' - sempre esta é desenvolvida em obediência aos parâmetros daquela" (MOREIRA, Egon Bockmann. Processo Administrativo - princípios constitucionais e a Lei n. 9.784/1999. São Paulo: Malheiros, 2010. p. 45).

${ }^{261}$ Lembrou-me o episódio narrado por Alejandro Nieto sobre a "assistente ilustre". Conta o autor que fazia uma conferência e demonstrava que a dependência política do Tribunal de Contas apoiando-se no sistema de designação de seus membros. Em dado momento uma assistente o adverte de que ele não havia lido o artigo 30.2 da Lei do Tribunal de Contas em que está bem claro que 'os conselheiros de contas do Tribunal são independentes". Dizia ela: 'Pois se isto disse a lei (...) em quem vamos crer: em uma lei democrática e constitucional ou aos comentários de um professor ressentido?'. Na sequência, o autor observa: 'Nota-se que a lei disse que são independentes; não que devam sê-lo ou que procurarão sê-lo. Logo se assim o disse a lei é que o são e não há mais que discutir, salvo se nós quisermos sair da lei: com o que não concordamos'. Por fim, conclui o administrativista espanhol: 'Este é o melhor e mais singelo exemplo da Razão Jurídica desviada: o Direito começa e termina na lei, o que possa haver detrás dela não interessa e a realidade que a contradiga não deve ser tomada em conta. Pior para a realidade!'” (ALEJANDRO NIETO. Crítica de la razón jurídica. Madrid: Editorial Trotas, 2007, p. 35-36). 
$\S 1^{\circ}$, da CR), ele poderá ofender ou a legalidade ou a moralidade ou ainda o princípio de eficiência, ou estes em combinação (e aqui, os princípios continuam sendo distintos um dos outros).

Nestas hipóteses, não há falar em ofensa ao princípio de impessoalidade.

Compreender de modo diverso é olvidar que a lei já contém sua dimensão de impessoalidade, que é diversa da do princípio em questão.

A propósito, sobre esta dimensão, lembrou-me Gastón Gèze ${ }^{262}$ ao discorrer sobre poderes jurídicos: "a essência da lei ou do regulamento consiste em formular regras gerais, impessoais, objetivas. Por essa razão se podem chamar situações legais ou regulamantárias as situações jurídicas gerais e impessoais. São, pois, termos sinônimos".

Relativamente à moralidade, a teoria do desvio de poder, bem conhecida do Direito Administrativo ${ }^{263}$, poderá ser um ponto de partida. A impessoalidade, na verdade, impõe que o agente administrativo seja obrigado assumir o ônus jurídicoadministrativo e social de sua decisão: que a exponha e se exponha por ela.

$\mathrm{O}$ agente administrativo não pode se apropriar da processualidade e do controle de seus atos. À sociedade - ao povo (RC, art. $1^{\circ}$, parágrafo único) - pertence este direito: um direito correlato ao da dignidade da pessoa humana enquanto cidadão.

Quanto à tese de imputação ${ }^{264}$, atente-se para o fato de que o Código Civil de 1916 já continha dispositivo no sentido de que as pessoas jurídicas de direito publico eram responsáveis por atos dos seus representantes que nessa qualidade causassem danos a terceiros, procedendo de modo contrario ao direito ou faltando a dever prescrito por lei, salvo o direito de regresso contra os causadores do dano (CC/1916, art. 15). Aliás, dispositivo semelhante veio com o Código Civil de 2002 (art. 43), tudo a indicar que o princípio de impessoalidade não se destinaria a esse fim.

Ainda que assim não fosse, a própria Constituição da República dispõe no $\S 6^{\circ}$, do art. 37, que “As pessoas jurídicas de direito público e as de direito privado prestadoras de serviços públicos responderão pelos danos que seus agentes, nessa qualidade, causarem a terceiros, assegurado o direito de regresso contra o responsável nos

\footnotetext{
262 JÈZE, Gaston. Principios generales del derecho administrativo. Carlos García Oviedo (Trad.). Bogotá: Axel Editores, 2010 (tradução nossa).

${ }^{263}$ Por exemplo, José Cretella Júnior (CRETELLA JÚNIOR, J. Anulação do ato administrativo por desvio de poder. Rio de Janeiro: Forense, 1978).

${ }^{264}$ Acrescente-se que a Teoria da aparência, também conhecida do direito brasileiro, satisfaz com suficiência qualquer dúvida sobre o fato de Estado poder responder por eventual exercício de fato de alguma pessoa irregularmente investida em suas funções, não havendo pertinência da incidência do princípio em questão.
} 
casos de dolo ou culpa". Vale dizer, não haveria pertinência de o princípio em questão dispor de modo semelhante.

O tema correlato à impessoalidade não é novo no Direito Administrativo $^{265}$, mas o princípio de impessoalidade é novidade no direito brasileiro, seja como signo, seja como significado.

A impessoalidade não diz respeito apenas à processualidade. Ela envolve também o controle. Ou seja, não apenas o rôle, mas também o contre-rôle, na lição de Odete Medauar ${ }^{266}$.

Entretanto, não se trata de uma processualidade 267 ou controle indiferentes e independentes. Ambos são finalísticos e interdependentes. Mas não de

265 FAGUNDES, Miguel Seabra. Controle dos Atos Administrativos pelo Poder Judiciário. $8^{\mathrm{a}}$ edição atualizada até 2010, por Gustavo Binenbojm. Rio de Janeiro: Forense, 2010. . Odete Medauar: A processualidade no direito administrativo, $2^{\mathrm{a}}$ ed., revista, atualizada e ampliada. - São Paulo: Editora revista dos Tribunais, 2008; Controle da Administração Pública, $2^{a}$ ed. ver., atual. - São Paulo: Editora Revista dos Tribunais , 2012; e O direito administrativo em evolução, São Paulo: Editora revista dos Tribunais, 1992, pp. 204-224. Paulo Magalhães da Costa Coelho: Controle Jurisdicional da Administração Pública - São Paulo: Saraiva, 2002. FREITAS, Juarez de. O Controle dos Atos Administrativos e os princípios fundamentais. $4^{\mathrm{a}}$ ed. refundida e ampliada. São Paulo: Malheiros, 2009. p. 82. BANDEIRA DE MELLO, Celso Antônio. Discricionariedade e Controle Jurisdicional. 2a ed. São Paulo: Malheiros, 2006. MEDAUAR, Odete. A processualidade no direito administrativo. $2^{\mathrm{a}}$ ed. rev. atual. e ampl. São Paulo: Editora Revista dos Tribunais, 2008. MEDAUAR, Odete, Controle da Administração Pública. $2^{\mathrm{a}}$ ed. rev. atual. São Paulo: Editora Revista dos Tribunais, 2012. MEDAUAR, Odete. O direito administrativo em evolução. São Paulo: Editora Revista dos Tribunais, 1992, pp. 204-224. COELHO, Paulo Magalhães da Costa. Controle Jurisdicional da Administração Pública. São Paulo: Saraiva, 2002. Freitas, Juarez. O Controle dos Atos Administrativos e os princípios fundamentais. $4^{\mathrm{a}}$ ed., refundida e ampl. São Paulo: Malheiros, 2009.Obras coletivas: MEDAUAR, Odete; SCHIRATO, Vitor Rhein (orgs). Os caminhos do ato administrativo São Paulo: Revista dos Tribunais, 2012 e MEDAUAR, Odete; SCHIRATO, Vitor Rhein (orgs). Atuais Rumos do Processo Administrativo. São Paulo: Revista dos Tribunais, 2010.

266 “O termo controle é galicismo, se considerado sob o ângulo da pureza linguística, mas hoje integra o vocabulário usual. Segundo Bergeron, no dicionário Quillet são atribuídos os seguintes significados ao termo rôle: a) peça de pergaminho mais ou menos longa, enrolada ou não, sobre a qual se escreviam os atos, os títulos; b) o registro oficial em que se escrevem nomes; c) no âmbito da marinha, o rôle de uma equipagem é a lista do estado civil da equipagem. O contre-rôle é o registro que efetua o confronto com o registro original e serve para verificar os dados; a expressão foi abreviada, resultando no temo controle. Essa mesma origem da palavra vem indicada por G.A. Vanni no trabalho 'Organizzazione degli uffici finzieri'. Para Giannini, o termo vem do 'latim fiscal medieval', contra rotulum (em francês contre-rôle - contrôle), que indica o exemplar do rol dos contribuintes, dos tributos, dos censos, sobre a base do qual se verifica a operação do exator. Essa mesma origem etimológica é apontada por Roberta Lombardi, como significado essencial de um fenômeno lógico de reexame ou revisão de uma atividade de outrem. Conforme Bergeron, 'a partir de 1654 numerosos atos jurídicos deviam ser controlados. Isto é, resumidos em registros especiais, mediante pagamento de uma taxa. Adquiriram, assim certa, vantagem, preciosa do direito privado, configurando um tipo de controle hoje denominado registro, que seria, então, o sentido originário do termo" (MEDAUAR, Odete. Controle da Administração Pública $2^{\mathrm{a}}$ ed. rev. atual. São Paulo: Editora Revista dos Tribunais , 2012. p. 19-20).

${ }^{267}$ Embora Niklas Luhmann (LUHMANN, Niklas. Legitimação pelo procedimento. Maria da Conceição Córte-Real (Trad.). Brasília: Editora Universidade de Brasília, 1980. (Coleção Pensamento Político 15)) tenha se utilizado da expressão "procedimento", podemos tomar de empréstimo sua lição para dizer que a processualidade é uma maneira de legitimação para o poder: a legitimação pela processualidade constitucional. Mutatis mutandis, em consonância com o princípio de impessoalidade, ensina este sociólogo alemão que "Procedimento deve ser aqui entendido como um sistema social de forma específica, portanto como uma solidariedade de sentido da ação fática; e legitimidade deve ser entendida como a tomada de 
qualquer finalidade. A finalidade está orientada pela Constituição. Daí poder-se falar que isoladamente a processualidade e o controle não representam o princípio de impessoalidade. Este se constitui da associação de ambos para os fins estabelecidos na Constituição.

De tudo o que se expôs, pode-se dizer que o princípio de impessoalidade está simultâneo e finalisticamente vinculado à noção de processualidade e de controle; tudo a permitir a ação administrativa e o controle constitucionalmente adequados.

Saliente-se, a esse respeito, que as regras desta processualidade e as deste controle devem ser as mesmas para os controlados e para os controladores: não pode haver surpresa, não pode este sistema trazer insegurança jurídica à Administração Pública e à Sociedade.

Nesse sentido o princípio de impessoalidade orienta para a reunião de toda a atividade administrativa do Estado (entenda-se: por si ou por aqueles que façam sua vez) para um locus.

Como consequência, por exemplo, isso poderá contribuir para: (a) a redução do campo de atuação política para as hipóteses estritas da Constituição [v.g., em relação ao Presidente, 'iniciar o processo legislativo, na forma e nos caos previstos nesta Constituição' (CR, art. 84, inc. III), "vetar projetos de lei, total ou parcialmente” (CR, art. 84, inc. V) etc.; ou em relação ao Governador, 'representar o Estado nas suas relações jurídicas, políticas e administrativas'(CE, art. 47, inc. I), 'enviar à Assembléia Legislativa projeto de lei sobre o regime de concessão ou permissão de serviços públicos’ (CE, art. 47, inc. XVIII) etc.]; (b) o redimensionamento da atividade discricionária; (c) a melhoria da função administrativa (v.g., sua responsividade, ou seja, capacidade de responder ás demandas da Sociedade); (d) melhoria dos órgãos e mecanismos de controle (v.g., seriam

decisões obrigatórias dentro da própria estrutura das decisões" (p. 7); "é típica a expectativa de que o próprio procedimento não constitui um critério de verdade mas favorece a correção da decisão; que possibilita e canaliza a comunicação; que garante a realização de decisões, independentemente do fato de que a lógica funcione, e permita ou não os cálculos apenas das soluções exatas; e que contribuiu para abolir as perturbações previsíveis" (p.17); "o núcleo de todas as teorias clássicas do procedimento é a relação com a verdade ou com a verdadeira justiça como objetivo" (p. 21); "torna-se difícil ver qual a outra forma, prescindido do recurso a uma ideia pré-concebida, de poder estabelecer a opinião de que o conhecimento verdadeiro e a verdadeira justiça constituem o objetivo e conjuntamente a essência dos procedimentos juridicamente organizados" (p. 23). Ainda interessante sua observação de que seu livro "não trata, portanto, de 'legitimar' a instituição do processo legal através da justificação duma função; trata, sim, da revelação do problema que a justificação resolvia e isso é facilmente omitido porque não se identifica com os problemas que se procuram resolver nos processos legais por meio das decisões" (p. 13). Por fim, cumpre lembrar a observação de Tércio Sampaio Ferraz Jr, que fez a apresentação do livro, no sentido de que "Sem eliminar o caráter decisório da legitimidade, ele [Luhmann] evita o problema do regresso a um decisão última, no início da série, mostrando que a legitimidade não está ali, mas no próprio processo que vai do ponto inicial do procedimento de tomada de decisão até a própria decisão tomada. É, assim, o procedimento mesmo que confere legitimidade e não uma de suas partes componentes" (p. 4). 
instigados a aprofundar, por exemplo, a investigação da configuração do dolo ou culpa do agente no âmbito da improbidade administrativa); (e) a formação e aprimoramento de uma cultura de precedentes; (f) a inspiração e ampliação da consciência social sobre os limites e potencialidades da Sociedade e da Administração Pública; (g) a facilitação do exercício da função jurisdicional $^{268} \mathrm{e}$ (h) a ampliação da realização constitucional etc.

Em outras palavras, tende a diminuir o campo de não-sindicabilidade dos atos da Administração Pública e a se transformar em fator de melhoria contínua da qualidade dos agentes e do produto do exercício da função administrativa.

Agir de modo impessoal é expor, registrando prévia ou simultaneamente, todos os fatos e fundamentos jurídicos que justificaram desde a tomada da decisão até sua efetiva materialização no mundo fenomênico ultraprocessual, em permanente comunicação com a Sociedade, o que viabilizará o controle.

O princípio não exige um ser impessoal ${ }^{269}$, mas um agir impessoal ${ }^{270}$.

O princípio de impessoalidade diz respeito ao dever jurídico que o agente administrativo tem de, em contínua comunicação com a Sociedade, registrar os fundamentos fáticos e jurídicos da decisão que elegeu o caminho escolhido para a sua atuação e os fatos e fundamentos jurídicos das decisões propriamente ditas que se seguiram no curso deste agir administrativo. Não se trata de um registro ad infinitum regressum. Mas do registro mediato da situação fático-jurídica que desencadeou o agir administrativo e o de seu desenvolvimento. Isso permitirá que a Sociedade e seus órgãos de controle acompanhem o desenvolvimento da função administrativa.

\footnotetext{
${ }^{268}$ Aqui a referência é de Egon Bockmann Moreira (MOREIRA, Egon Bockmann. Processo Administrativo - princípios constitucionais e a Lei n. 9.784/1999. São Paulo: Malheiros, 2010. p. 22-23).

${ }^{269}$ Esta situação lembrou-me a lição de Agustín Gordillo. Sob o subtítulo A irrealidade e o excesso como forma de irrazoabilidade, o administrativista argentino registrou: "Relatava Bielsa que um constitucionalista brasileiro, ao ser consultado sobre que reformas proporia à Constituição, propôs a seguinte: 'Artigo único: Todo brasileiro fica obrigado a ter vergonha'. Se resume ali, por uma parte, a irrealidade de querer tudo leválo a uma norma escrita, e por outra, que a chave do bom funcionamento de um sistema não está tanto em seu texto como nos valores com os quais os cidadãos efetivamente se comportam, e que de nada vale, sem tais valores, qualquer esquema constitucional e qualquer aspiração que nele expressamos" (GORDILLO, Agustín. La administración paralela. Madrid: Cuadernos Civitas, 2011. p. 27. (tradução nossa).

${ }^{270}$ Num exercício metafórico, considerando que o princípio de impessoalidade, com este signo, pode ser considerado uma criação nacional, poderíamos compará-lo a dois elementos da cultura nacional: a novela e o futebol. Cremos que o princípio está ligado ao futebol: as mesmas regras geram resultados coletivos diferentes dependendo do empenho dos atletas. A novela, ao contrário, fruto da criação do autor que, quando muito, ao obter auxílio, apenas seleciona o que lhe interessa, arbitrariamente, independe, em princípio, dos atores. Aquela, a estória, já está pronta. Neste o jogo está para ser jogado no campo, a ser revelado. O princípio tal como o futebol exige um agir num locus e envolve jogadores e expectadores (rectius: controlados e controladores). A concreção adequada do interesse público, v.g., poderia ser comparada à experiência de vitória. O próximo capítulo da novela, um expediente para revelar a vontade do autor.
} 
Este princípio reposiciona o agir administrativo para aquilo que se poderia chamar de uma Teoria Geral do Processo ${ }^{271}$, ou para aquilo que Guy Braibant, Nicole Questiaux e Celine Wiener, na década de 70 do século XX, chamavam de relativa indiferenciação ${ }^{272}$ entre o processo administrativo e o judicial ao examinarem o sistema de controle administrativo sueco que pressupõe princípios e organização administrativa.

271 “Costuma ser dito que o processo é o instrumento da jurisdição. Ele é, na verdade, o instrumento de que se vale o estado, não só para exercer jurisdição, mas, numa colocação mais ampla, par ao exercício do poder. As modernas doutrinas em sede de teoria do processo ressaltam o valor do procedimento e do contraditório, na preparação do ato imperativo (provimento) que o Estado emitira no processo (...) Esses, para a efetividade da participação em contraditório, hão de obedecer a certos requisitos de forma e a uma seqüência lógica que a lei impõe porque sabe (mercê da experiência herdada secularmente) que assim é que a participação poderá ser justa e proveitosa. Eis o valor do procedimento, no sistema processual (...) A teoria do processo como relação jurídica tem sofrido crítica, de ontem e de hoje, por diversos aspectos. A mais penetrante foi a formulada por James Goldschmidt, que em conhecido estudo de Liebman examinou e criticou. Já existe suficiente maturidade, todavia, para entender que o processo não é a relação jurídica processual, ou seja, ele não se exaure nela. A análise jurídica do processo mostra ser ele uma entidade complexa, onde compareceu dois componentes: o procedimento e a relação jurídica processual. Considera-se processo todo o procedimento animado pela relação jurídica processual. Esse conceito por um lado, é bastante ampla e permite que se reconheça a natureza de processo (e não mero procedimento) a procedimentos que se celebram perante autoridade administrativa, sem o exercício de jurisdição. Por outro lado, valoriza o procedimento, em termos coincidentes com os da moderna doutrina sustentada por Fazzalari. Postas as coisas assim, não há por que repudiar a inserção da relação jurídica processual no conceito de processo, como se ela fosse repudiada, ou substituída, pela presença do contraditório. Ela é, como venho dizendo, a expressão e forma jurídica da exigência política consubstanciada neste. Pois a disciplina legal do processo, com o desenho do procedimento em abstrato e definição das situações ativas e passivas integrantes da relação jurídica processual, constitui, antes e acima de tudo, a disciplina do exercício do poder e um sistema de limitações a ele" (DINAMARCO, Cândido Rangel. Fundamentos do processo civil moderno. $4^{\mathrm{a}}$ ed. revisão e atualização de Antônio Rulli Neto. São Paulo: Malheiros, 2001. pp. 101-103. Tomo 1). Interessante a lição de Egon Bockmann Moreira a respeito: "Defendemos ideia paralela à do direito processual (teoria geral, civil e penal) - a de que o termo 'processo' requer a existência de relação jurídica própria e o termo 'procedimento' designa unicamente a sequiência de atos nela contida. Isso, em face do direito administrativo, pode ser concebido da seguinte forma: há duas espécies de exercício das atividades administrativas, expressadas em duas locuções, pertinentes a um mesmo regime jurídico-administrativo: 'função administrativa' e 'relação jurídico-administrativa'. Não são termos opostos, mas continente e conteúdo (parcial). A função administrativa pode ser exercida pontual e internamente à Administração, mas a relação jurídicoadministrativa é caracterizada pela conexão natural que existe entre dois ou mias sujeitos (públicos e privados). Ora, se o termo 'processo' designa inequivocamnte uma relação jurídica, sempre que houver tala relação haverá processo. Caso contrário é exercido natural da função administrativa. ${ }^{67}$ ". Nesta nota de rodapé n. 67, o autor registra:"que poderia se denominado de 'procedimento' (...)"(MOREIRA, Egon Bockmann. Processo Administrativo - princípios constitucionais e a Lei n. 9.784/1999. São Paulo: Malheiros, 2010. p. 54-55). A propósito, lembremos que na época do Império existia o que se chamava de processo administrativo puro, que, nas palavras de Pimenta Bueno, "também se pode chamar de ativo ou gracioso, não tem termos, fórmulas, nem dilações ou condições fixas” (KUGELMAS, Eduardo (organização e introdução). José Antônio Pimenta Bueno, Marquês de São Vicente. São Paulo: Ed. 34, 2002. p. 384).

272 "O sistema de controle sueco se caracteriza ao mesmo tempo pela importância que ele atribui em relação à legalidade, entendida no sentido de proteção dos direitos individuais, e pela existência de instituições originais que encontram seu fundamento na organização administrativa do país e na evolução histórica da repartição dos poderes. A submissão da administração à legalidade tem sempre sido na Suécia uma preocupação primordial. O ideal de uma sociedade inteiramente governada pela lei, e uma visão muito protetora dos direitos dos cidadãos leva a cercar-se de cuidados a atividade administrativa de uma rede fechada de garantias. Também os agentes públicos são tradicionalmente obrigados, no exercício de suas competências, a respeitar as formas e os princípios análogos aos do processo judicial: oficializando esta obrigação, o Código de processo recentemente adotado não fez senão consagrar um costume seguido de longa data em nome das regras fundamentais que governam a nação e evocadas nos textos constitucionais. Por outro lado, um poderoso auxiliar do respeito da legalidade está em ser o direito, igualmente reconhecido 
A impessoalidade administrativa, no Brasil, ainda é parcial e muito pouco desenvolvida e, em princípio, se limita a casos das esferas Federal e Estadual $^{273}$.

Os municípios ${ }^{274}, \quad$ v.g., parecem não conhecer o princípio de impessoalidade: improvisam nesse aspecto, contribuindo para a ofensa da ordem constitucional.

\section{Compulsando manuais de Direito Administrativo é possível perceber que} a processualidade sustentada se limita à atuação provocada da Administração Pública ou daquela que diretamente atinge um direito particular (v.g., de uma empresa privada específica, a de um determinado cidadão). A processualidade está esquecida em relação aos demais atos da Administração Púbica (v.g., aqueles chamados atos de ofício, ou seja,

pela Constituição, algo que pertence a todos os cidadãos de tomar conhecimento dos documentos em poder da administração, a que ela está por ela mesma, para uma boa parte de sua atividade, forçada a funcionar a céu aberto" (p. 71). "Uma outra particularidade do sistema sueco, que está nas origens da história das instituições, é a relativa indiferenciação entre administração e justiça. Nos tempos antigos, os mesmos órgãos se manifestavam nas mesmas formas as decisões administrativas e judiciais, sob o controle de um autoridade suprema única, o Rei, que podia reformar em última instância tanto os julgamentos quanto os atos ditos executivos. A partir do século XIX, sob a influência das concepções da Revolução francesa, uma certa separação das funções se instaura, mas sua falta de clareza original - da qual subsiste de resto numerosos vestígios - tem marcado profundamente as instituições. Ela explica notadamente a similitude dos regimes que regem as duas ordens de atos: considerados como cumprindo fins análogos, eles são submetidos a regras de forma e de processo muitos visinhas e se beneficiam de uma autoridade jurídica sob este ponto de vista análogo" (p. 73) (BRAIBANT, Guy; Nicole QUESTIAUX, Nicole; WIENER, Celine. Le controle de l'administration et la protection des citoyens, Étude comparative. Paris: Éditions Cujas, 1973. (tradução nossa)).

${ }^{273}$ A título de exemplo, podemos citar a Lei n. 9.784/99, que, de fato é um grande avanço, mas regula o processo administrativo no âmbito da Administração Pública federal e parece ter uma aplicação que chamaríamos de restrita, porque, em princípio, tem utilidade para a atuação provocada pelo cidadão ou de iniciativa da Administração quando atinge pretensões individuais. Um outro exemplo, que avança um pouco mais a processualidade, mas de alguma forma também estaria circunscrita a atuação que atinja direitos individuais é o da Lei Estadual n. 10.177, de 30 de dezembro de 1998, que regula o processo administrativo no âmbito da Administração Pública Estadual, cujo art. $7^{\circ}$, dispõe que "A Administração não iniciará qualquer atuação material relacionada com a esfera dos particulares sem a prévia expedição do ato administrativo que lhe sirva de fundamento, salvo na hipótese de expressa previsão legal". Outro exemplo, agora dispondo sobre a possibilidade, regulada, de os funcionários alterarem o local de trabalho, podemos citar a Portaria n. 8.857/2013, do TJSP, que regulamento o processo de remoção de servidores do Tribunal de Justiça.

${ }^{274}$ Egon Bockmann Moreira observa a possibilidade da aplicação da Lei n. 9.784/1999 a Estados, Municípios e Distrito Federal (MOREIRA, Egon Bockmann. Processo Administrativo - princípios constitucionais e a Lei n. 9.784/1999. São Paulo: Malheiros, 2010. p. 21, nota de rodapé n. 1). Sobre o tema, Celso Antônio Bandeira de Mello registra o seguinte: "Ocorre que, até bem pouco tempo, não havia um alei geral sobre processo ou procedimento administrativo, nem na órbita da União, nem na órbita dos Estados ou Municípios. Existem apenas normas esparsas concernentes a um outro procedimento, o que, por certo, explica, ao menos em parte, esta discreção sobre o tema. Só no início de 1999 foi editada, para a esfera federal, a Lei 9.784, de 29 de janeiro, que: 'Regula o processo administrativo no âmbito da Administração Pública Federal'. No final do ano anterior, no Estado de São Paulo já surgira a Lei 10.177, de 30.12.98, cuja emenda, correspondentemente, reza: 'Regula o processo administrativo no âmbito da Administração Pública Estadual'. Na verdade, precedendo a ambas existe a lei, tanto quanto saibamos pioneira, que é a lei complementar do Estado do Sergipe, n. 33, de 26.12.96, a qual 'Institui o Código de Organização e de Procedimento da Administração Pública do Estado de Sergipe" (BANDEIRA DE MELLO, Celso Antônio. Curso de Direito Administrativo. $21^{\mathrm{a}}$ ed. rev. e atual. até a Emenda Constitucional 52, de 8.3006 - São Paulo: Malheiros, 2006, pp. 463-464). 
aqueles que não são provocados, e que se identificam com aquilo que se denomina o campo da discricionariedade administrativa que, por certo, também têm a sociedade, a coletividade, como destinatária).

Aliás, tais atos integram a grande parte da função administrativa.

Tem-se a impressão de que a processualidade administrativa destes manuais concebe, como parte dela, apenas o cidadão, apenas a pessoa jurídica particular, e se esquece da sociedade, da coletividade. Esta miopia processualística impede que a Sociedade enxergue a si e a seus agentes públicos como pretende a Constituição.

É como se, mesmo na ordem constitucional vigente, utilizássemos do expediente imperial para distinguir a atividade administrativa e, por conseguinte, o que tudo isso gera de problemas à Sociedade. Vale dizer, o processo administrativo é apenas para as questões que envolvam lide concreta com interessados definidos o imputação disciplinar, o restante estaria no âmbito da processualidade graciosa, podendo classificá-las em procedimentos internos e externos; aqueles dizem "à intimidade, à vida intestina da Administração"275, estes podem ser ampliativos ou restritivos e a estes se permitem o processo com as garantias próprias.

A doutrina administrativista se mostra tímida ${ }^{276}$ em não admitir o ingresso integral da função administrativa na impessoalidade. Insiste-se ${ }^{277}$ em discutir a distinção de processo e procedimento e o enquadramento dos institutos no Direito Administrativo e, de algum modo, contribuem para o descompasso mencionado por Marçal Justen Filho.

\footnotetext{
${ }^{275}$ A expressão é de Celso Antônio Bandeira de Mello (BANDEIRA DE MELLO, Celso Antônio. Curso de Direito Administrativo. 21 a ed. rev. e atual. até a Emenda Constitucional 52, de 8.30 .06 - São Paulo: Malheiros, 2006. p. 476). Aliás, expressamente o autor exclui da processualidade ampla aquilo que denominou 'procedimento internos'. E o fez nestes termos: "Evidentemente, o que interessa, sobretudo, são os procedimentos externos, pois é em relação a eles que se põe o tema - a ser ao final desenvolvido - dos princípios que se lhes aplicam e, em consequência, as garantias que oferecem ao administrado".

${ }^{276}$ Embora faça menção à lição do austríaco Merkel, que já em 1927 dizia que o processo não era fenômeno exclusivo do poder judiciário, que "Todas as funções estatais e, em particular, todos os atos administrativos são metas que não podem ser alcançadas senão por determinados caminhos" e ainda que "o caminho que se percorre para chegar a um ato constitui aplicação de uma norma jurídica que determina, em maior ou menor grau, não apenas a meta, mas também o próprio caminho, o qual, pelo objeto de sua normação, apresenta-se como norma processual" (p. 466), Celso Antônio Bandeira de Mello acaba por sintetizar que existem procedimentos internos e externos (ampliativos - de iniciativa do interessado ou de iniciativa da Administração - e restritivos - ablativos ou sancionadores), dando a impressão de que nem toda atividade administrativa deva se submeter à processualidade (BANDEIRA DE MELLO, Celso Antônio. Curso de Direito Administrativo. $21^{\mathrm{a}}$ ed. rev. e atual. até a Emenda Constitucional 52, de 8.30.06,. São Paulo: Malheiros, 2006. pp. 466,475-477). Em sentido semelhante, Demian Guedes (GUEDES, Demian. Processo Administrativo e democracia, prefácio de Leonardo Greco; apresentação de Marcos Juruena Villela Souto. Belo Horizonte: Fórum, 2007, pp. 67-70).

${ }^{277}$ Egon Bockmann Moreira examina criticamente o pensamento de três administrativistas sobre o tema (MOREIRA, Egon Bockmann. Processo Administrativo - princípios constitucionais e a Lei n. .784/1999. São Paulo: Malheiros, 2010. pp. 47-64).
} 
Aliás, saliente-se que até pouco tempo a doutrina compreendia o processo administrativo como "o meio de se apurar irregularidade no serviço público" 278 . E nesse aspecto, especificamente o processo "promovido pela autoridade que souber da irregularidade, assegurando-se ao acusado direito de ampla defesa”.

Considerando a nova ordem constitucional, rica em fundamentos e objetivos, pródiga em direitos e garantias individuais e coletivas e fortalecida por princípios de Administração Pública finalísticos, não se mostra possível retirar parte da ação da Administração Pública da impessoalidade.

A impessoalidade amplia a processualidade.

Como é possível verificar, certificar-se, convencer-se, de que um ato administrativo (em sentido amplo) efetivamente está em sintonia com o fundamento de dignidade da pessoa humana (CR, art. $1^{\circ}$, inc. III), se é compatível com o objetivo de construir uma sociedade livre, justa e solidária (CR, art. $2^{\circ}$, inc. I), por exemplo, que deve promover o bem de todos, sem preconceitos de origem, raça, sexo, cor, idade e quaisquer outras formas de discriminação (CR, art. $3^{\circ}$, inc. IV) e ainda se respeita os princípios de legalidade, de moralidade e de eficiência?

A impessoalidade, no âmbito de uma democracia, em um regime do poder visível, na expressão já mencionada de Norberto Bobbio, é um caminho sem volta.

A concreção do princípio de impessoalidade passa por essa mudança de pensamento e necessidade de procedimentos (leis, resoluções, portarias etc.) que lhe deem operacionalidade prática.

A despeito de entendimento contrário ${ }^{279}$, anote-se que a Constituição da República não trata expressamente desta processualidade nos dispositivos em que dispõe sobre processo ${ }^{280}$.

${ }^{278}$ BARROS, Gessner P. Pompêo de. Princípios de Administração Pública. $2^{\mathrm{a}}$ edição. Rio de Janeiro: Gráfica Editôra Aurora, 1959. p. 209.

${ }^{279}$ Pelo que se infere da lição do professor Floriano de Azevedo Marques Neto, o vetor da processualidade administrativa está no art. 5, inc. LV, da Constituição da República: "Mais do que assegurar este direito (que poderia já ser considerado como existente e protegido no regime constitucional anterior), a prescrição constitucional acabou por ter um efeito colateral que se revelou ainda mais importante. Ao lançar mão da fórmula 'litigantes em processo administrativo' o texto da Constituição acabou por consagrar que a atividade administrativa, o exercício da função administrativa, não é atividade que se realize isolada dos interesse e pretensões dos administrados. Se a Carta admite a existência de litigantes em processo administrativo (é dizer, em processos vocacionados à edição de um ato administrativo), é porque pressupõe haver pretensão resistida (lide, conflito, antagonismo) no processo de produção do ato. Logo, seja ontologicamente, seja operativamente, a edição de atos administrativos não poder ser concebida mais de forma autista, infensa à participação e à consideração dos diversos interesses envolvidos. Para além das consequências diretas da sujeição da atividade administrativa ao processo (participação dos interessados, contraditório, direito de aduzir suas razões e produzir provas, direto a uma manifestação de outra autoridade no curso do manejo recursal), tem-se que a prescrição constitucional cria um dever para a Administração Pública de conduzir a 
Os dispositivos constitucionais do art. 93, inc. IX e XX tratam de decisões administrativas no âmbito dos tribunais. Ou seja, na esfera do Poder Judiciário.

A norma do art. $5^{\circ}$, inc. LX, da CR, cuida apenas de processo administrativo $^{281}$ em que haja "litigantes" e "acusados em geral". Vale dizer, processo administrativo iniciado pela Administração Pública ou pelo interessado e que já tenha lide concreta (pretensão resistida) ou imputação de um fato, respectivamente. Daí a pertinência de equipará-los (tendê-los) ao processo judicial, conferindo-lhes as garantias pertinentes como a da ampla defesa, do contraditório etc. Ou seja, só se garante ampla defesa para alguém que tenha contra si a possibilidade concreta de se submeter diretamente à decisão administrativa advinda de lide ou imputação concretas.

O princípio de impessoalidade possibilitará a realização e preservação de um estado de coisas (legalidade, moralidade, eficiência etc.). Para a realização deste propósito são necessários determinados comportamentos. Para cumprir a lei - o princípio de legalidade - é preciso que o agente revele e demonstre isso. Para que ele atenda ao princípio de moralidade é necessário que justifique de que forma o fez. E assim por diante. Sem que se possibilite isso tudo não se concretiza o princípio de impessoalidade.

Utilizando-se de expressão processual, pode-se dizer que o princípio de impessoalidade inspira, no exercício da função administrativa, a inversão do ônus da prova $^{282}$ : caberá à Administração Pública demonstrar que a exerceu adequadamente.

Pertinente ainda ao tema exposto, a lição de Humberto Ávila ${ }^{283}$ : “O importante é que, se o estado de coisas deve ser buscado, e se ele só se realiza com

prática dos atos administrativos em permanente comunicação com os setores potencialmente atingidos, de forma positiva ou negativa, pelo ato ser praticado ao fim do processo necessário" (MARQUES NETO, Floriano de Azevedo. A superação do ato administrativo autista. In MEDAUAR, Odete; SCHIRATO, Vitor Rhein (orgs). Os caminhos do ato administrativo São Paulo: Revista dos Tribunais, 2012. pp. 108-109).

${ }^{280}$ Art. 5\%, inc. LIII e inc. LV, e art. 93, inc. IX e X, da Constituição da República.

${ }^{281}$ Pertinente aqui a lição de Egon Bockmann Moreira: "Tome-se o tome-se como exemplo o processo de licitação. Em seu desenvolvimento normal não há acusados (...) Também o curso amigável de desapropriação estabelece vínculo jurídico-administrativo entre Estado e particulares. O mesmo se diga quanto aos processos desenvolvidos frente ao CADE ou agências reguladoras. Essas relações jurídicas não necessariamente derivam nem envolvam 'litigância' e/ou 'acusação', mas configuram 'processo administrativo'. Cremos que eventual diferenciação entre processo e procedimento não reside na litigiosidade e/ou caráter acusatório da seqüência de atos a ser praticada pela Administração. Tal somente seria possível caso houve disciplina de direito positivo assim o definindo" (MOREIRA, Egon Bockmann. Processo Administrativo - princípios constitucionais e a Lei n. 9.784/1999. São Paulo: Malheiros, 2010. p. 54). Ou seja, é a Constituição da República que dispõe que o processo administrativo é assegurado aos litigantes e aos acusados em geral. Nas palavras deste autor, há "disciplina de direito positivo assim o definindo".

282 Sobre o tema, numa visão mais restritiva, escreveu Demian Guedes: "Também o princípio da impessoalidade (CR, artigo 37, caput) favorece o entendimento de que o poder Público deve, no processo administrativo restritivo de direitos, produzir prova dos pressupostos fáticos de seus atos" (GUEDES, Demian. Processo administrativo e democracia. Leonardo Greco (prefácio). Marcos Juruena Villela Souto. Belo Horizonte: Fórum, 2007, p. 128). 
determinados comportamentos, esses comportamentos passam a constituir necessidades práticas sem cujos efeitos a progressiva promoção do fim na se realiza. Como afirma Weinberger, a relação meio/fim leva à transferência da intencionalidade dos fins para os meios. ${ }^{118}$ Em outras palavras, a positivação de princípios implica a obrigatoriedade da adoção dos comportamentos necessários à sua realização, salvo se o ordenamento jurídico predeterminar o meio por regras de competência.

As considerações antes feitas demonstram que os princípios não são apenas valores cuja realização fica na dependência de meras preferências pessoais. Elas são, ao mesmo tempo, mais do que isso e algo diferente disso. Os princípios instituem o dever de adotar comportamentos necessários à realização de um estado de coisas ou, inversamente, instituem o dever de efetivação de um estado de coisas pela adoção de comportamentos a ele necessários. Essa perspectiva de análise evidencia que os princípios implicam comportamentos, ainda que por via indireta e regressiva. Mais ainda, essa investigação permite verificar que os princípios, embora indeterminados, não o são absolutamente. Pode até haver incerteza quanto ao conteúdo do comportamento a ser adotado, mas não há quanto à sua espécie: o que for necessário para promover o fim é devido.

Logo se vê que os princípios, embora relacionados a valores, não se confundem com eles. Os princípios relacionam-se aos valores na medida em que o estabelecimento de fins implica qualificação positiva de um estado de coisas que se quer promover. No entanto, os princípios afastam-se dos valores, porque, enquanto os princípios se situam no plano deontológico e, por via de consequência, estabelece a obrigatoriedade de adoção de condutas necessárias á promoção gradual de um estado de coisas, os valores situam-se no plano axiológico ou meramente teleológico e, por isso, apenas atribuem uma qualidade positiva a determinado elemento ${ }^{119}$ ".

Por fim, tal como Norberto Bobbio registrara, o que se escreveu e se transcreveu também foi guiado pela preocupação de "fazer descer a democracia do céu dos princípios para terra onde se chocam interesses consistentes. Sempre pensei que este é o único modo de dar conta das contradições que atravessam uma sociedade democrática e das tortuosas vias que se deve guiar para delas escapar sem confundir-se, para reconhecer

283 ÁVILA, Humberto. Teoria dos princípios: da definição à aplicação dos princípios jurídicos. $6^{\text {a }}$ edição revista e ampliada. São Paulo: Malheiros, 2006. p. 80. Observe-se que nas notas de rodapé, o autor faz menção a Ota Weinberger e Robert Alexy e Eros Roberto Grau. 
seus vícios congênitos sem desencorajar-se e sem perder toda a ilusão nas possibilidades de melhorá-la",284

${ }^{284}$ BOBBIO, Norberto. O futuro da democracia. Marco Aurélio Nogueira (Trad.). São Paulo: Paz e Terra, 2000. p. 24. 


\section{CONCLUSÃO}

Indubitavelmente, não pretendemos que a Constituição da República seja a folha de papel de Ferdinand Lassale ${ }^{285}$.

Isso, por exemplo, pressupõe a compreensão das categorias jurídicas estabelecidas pela Constituição (v.g., de seus princípios). Compreensão leva à possibilidade de normatividade.

O princípio de impessoalidade é antes de tudo uma decisão política, política-administrativa. Não é uma decisão administrava passível de revogação.

Este princípio, na ordem constitucional vigente no Brasil, como princípio específico da Administração Pública, tem como seus princípios constitucionais estruturantes (sem pretensão de exaustividade): o princípio do Estado de Direito (CR, art. $1^{\circ}$ ), o princípio republicano (art. $1^{\circ}$ ), o princípio democrático (art. $1^{\circ}$, caput, parágrafo único), o princípio de inafastabilidade de jurisdição (CR, art. $\left.5^{\circ}, \mathrm{XXXV}\right)$, o princípio de dignidade da pessoa humana $\left(\mathrm{CR}\right.$, art. $1^{\circ}$, inc. III) e aquele que se poderia denominar princípio de construção social (CR, art. $3^{\circ}$, inc. I).

A função administrativa, à vista da nova ordem constitucional, somente se exerce no âmbito de impessoalidade. Toda a atividade estatal se faz pela impessoalidade. O Estado é uno. Ele é dividido em funções para desempenhá-las adequadamente. Tal divisão não as retira do âmbito da impessoalidade, embora os procedimentos devam se adequar às respectivas relações jurídico-administrativas.

Retomando o início do trabalho, de fato o princípio de impessoalidade é uma nova concepção de mundo para a Administração Pública. Embora os temas correlatos à impessoalidade - como processualidade e controle - não sejam estranhos ao Direito Administrativo brasileiro, o princípio é diferente de tudo o que já vivenciamos em matéria de Direito Administrativo e, nesse sentido, ele é uma novidade para o direito nacional, seja como signo, seja como significado.

Relativamente a seu signo, dada a especificidade e conteúdo ativo (de ação, que pressupõe uma finalidade), o signo princípio de impessoalidade é mais adequado que o de princípio da impessoalidade, nos termos do que dispõe o art. 37, caput, da Constituição. Aliás, o dispositivo constitucional utiliza aquela expressão e não esta.

285 "Tenho demonstrado a relação que guardam entre si as duas Constituições de um país: essa constituição real e efetiva, integralizada pelos fatores reais e efetivos que regem a sociedade, e essa outra Constituição escrita, a qual, para distingui-la da primeira, vamos denominar folha de papel" (LASSALE, Ferdinand. $O$ que é a Constituição? Leme: CL EDIJUR, 2012. p. 35) 
O princípio definitivamente existe no ordenamento jurídico: é princípio e não regra de impessoalidade. É um princípios instrumental e não substancial.

Ele surge menos da noção de Patrimonialismo do que da estrutura jurídico-administrativa existente no país, caracteristicamente anômica, com grandes vazios de ausência de Estado impessoal. O Patrimonialismo é consequência, não sua causa.

Esta estrutura inevitavelmente cria ambiente propício para aquilo que Fred. W. Riggs chama de formalismo. Em síntese: discrepância entre a conduta concreta e a norma prescrita que se supõe regulá-la. Isso tudo com grave prejuízo para o senso coletivo de país que espera avançar no cumprimento de seus objetivos.

A ilustração de Fred W. Riggs, que poderíamos chamar de metáfora do mapa, bem pode fazer refletir se as instituições administrativas possuem instrumentos formais de fácil acesso à estrutura administrativa organizacional: ou na expressão de Gomes Canotilho da capacidade de caminhar. Ou seja, a efetivação dos objetivos e fundamentos e princípios consagrados na Constituição necessitam de uma estrutura processualizada que lhe dê operacionalidade prática. Se há estabelecimento de fins a serem atingidos é preciso que se acompanhe o desenvolvimento da função administrativa para se verificar se estes fins estão mesmo sendo atingidos pelos parâmetros constitucionais (v.g., legalidade, moralidade e eficiência), se há necessidade de reparos, adaptações na processualística adotada.

A impessoalidade retira a discricionariedade nos meios ou modos de se atingir os objetivos. De fato a instituição dos fins é ponto de partida à procura dos meios, mas estes devem permitir à sociedade acompanhar a concreção daqueles, criticá-los.

O expediente imperial de distinguir interesses e direitos, processo gracioso e contencioso parece ainda resistir ao tempo e ao ordenamento constitucional vigente, impedindo ampliação (pelo princípio de impessoalidade) da processualidade na função administrativa.

É, pois, quando, por exemplo, admitem classificações e distinções de "procedimentos" que pressupõe um extenso campo da função administrativa fora da impessoalidade.

A falta de um mínimo consenso (apto a gerar normatividade) sobre o significado do princípio parece estar apegada ao sentido do termo impessoal no dicionário, não se chegando à diferença entre ser impessoal e agir de modo impessoal, que é distintiva do princípio. Impessoal, a partir do termo persona, nos termos do princípio, pode significar, por exemplo, tangibilidade, permeabilidade; controlabilidade, passível ou 
tendente ao controle; submissão, responsividade; que considera, que não age sem indiferença. Ou ainda, em sentido figurado: sem máscara.

A impessoalidade, como se observa, parece reposicionar o Poder Executivo (cuja atividade é predominantemente administrativa) à processualidade e, com isso, aumentar seu potencial de, como integrante do Estado, de exercer sua função e, por conseguinte, diminuindo as atividades do Poder Judiciário. Inúmeras ações judiciais, por exemplo, poderiam ser evitadas se a Administração Pública, no âmbito da função administrativa, desse respostas mais claras, precisas e tempestivas.

Parece haver uma certa timidez da doutrina nacional no sentido de não admitir o ingresso integral da função administrativa na impessoalidade. Insiste-se, como já se observou, v.g., em discutir a distinção de processo e procedimento e o enquadramento dos institutos no Direito Administrativo, enquanto muitos municípios ainda estão fora da processualidade.

A impessoalidade não diz respeito apenas à processualidade. Ela envolve também o controle. Ou seja, não apenas o rôle, mas também o contre-rôle, na lição de Odete Medauar. Entretanto, não se trata de uma processualidade ou controle indiferentes e independentes. Ambos são finalísticos e interdependentes. Mas não de qualquer finalidade. A finalidade está orientada pela Constituição. Daí poder-se falar que isoladamente a processualidade e o controle não representam o princípio de impessoalidade. Este se constitui da associação de ambos para os fins estabelecidos na Constituição. Em outras palavras, o princípio de impessoalidade está simultâneo e finalisticamente vinculado à noção de processualidade e de controle; tudo a permitir a ação administrativa e o controle constitucionalmente adequados.

Esta processualidade e este controle deverão gerar regras semelhantes aos controlados e aos controladores: não pode haver surpresa, não pode este sistema trazer insegurança jurídica à Administração Pública, às Instituições e à Sociedade.

A impessoalidade parece suscitar o tema de quem controla o controlador. E aqui a lição é de Norberto Bobbio, mutatis mutandis, que discorria sobre o mecanismo do Panopticon, de Bentham: "é a questão que os escritores políticos de todos os tempos, a começar por Platão, puseram como questão última de toda a teoria do Estado: 'Quem vigia o vigilante?' Quis custodiet custodes? A resposta habitual consiste em pressupor um vigilante superior, até que se chegue necessariamente (pois nas coisas práticas está proibido o recurso ao processo infinito) ao vigilante que não é vigiado porque não há mais nenhum vigilante superior acima dele. Mas que é o vigilante não-vigiado? A questão é tão 
importante que as diversas doutrinas políticas podem ser classificadas com base na resposta que deram a ela: Deus, o herói fundador do Estado (Hegel), o mais forte, o partido revolucionário que conquista o poder, o povo entendido como a inteira coletividade que se exprime através do voto. A seu modo, Bentham é um escrito democrático, que assim resolve o problema do vigilante não-vigiado: o edifício poderá ser facilmente submetido a inspeções contínuas não só por inspetores designados mas também pelo publico. Esse expediente representa uma fase ulterior dissociação da dupla 'ver-se visto'. O prisioneiro é o não-vidente visível, o vigilante é o vidente visível, o povo completa a escala enquanto vidente não-visto a não ser por si mesmo e que é, portanto, com respeito aos outros, invisível. O vidente invisível é ainda uma vez o soberano".

Poderiam ser listadas como consequência da normatividade do princípio em questão, o fato de poder contribuir para: (a) a redução do campo de atuação política para as hipóteses estritas da Constituição (redução daquilo que se denomina atos políticos); (b) o redimensionamento da atividade discricionária (trazendo-a para o processo e para o controle finalísticos); (c) a melhoria da função administrativa (v.g., sua responsividade, ou seja, capacidade de responder às demandas da Sociedade); (d) melhoria dos órgãos e mecanismos de controle (v.g., ampliações de agentes nos órgãos de controle, tecnologia etc.); (e) a formação e aprimoramento de uma cultura de precedentes; (f) a inspiração e ampliação da consciência social sobre os limites e potencialidades da Sociedade e da Administração Pública; (g) a facilitação do exercício da função jurisdicional e (h) a ampliação da realização constitucional etc.

Enfim, o princípio em estudo tende a promover um ambiente para que o Estado e a Sociedade, em diálogo contínuo, confirmem (ou não!) os objetivos, fundamentos, princípios e direitos consagrados na Constituição, uma tentativa de dar sentido ao Brasil.

Sobre tudo isso ser fruto de criatividade imaginativa, lembrou-me a ilustração de Agustín Gordillo. Este administrativista argentino ${ }^{286}$, ao discorrer sobre o papel do jurista, relata um episódio envolvendo o filho de um colega que havia dito à mãe que quando ele crescesse não pretendia fazer o que seu pai fazia e indagado pela mãe aquele lhe explicara que pretendia fazer coisas, pontes, caminhos, e não hacer papeles como papá. A percepção e a advertência do filho além de indicar o que entendia acerca da

${ }^{286}$ GORDILLO, Agustín. El Metodo em Derecho - Aprender, enseñar, escribir, crear, hacer. Madri: Civitas Ediciones, 1988. p. 24. (tradução nossa). Hacer papeles poderia ser traduzido como escrever; ou ainda, em sentido figurado como exercer um cargo, uma função (DICCIONARIO DE SINÓNIMOS ANTÓNIMOS E IDEAS AFINES - Larousse . Mexico, 2008).. 
função social da atividade do pai, não estava de todo equivocada, como observou logo em seguida o autor: seu pai fundamentalmente escrevia, ou tinha ideia que tomavam corpo ou eram expressas em escritos, assim como os engenheiros e arquitetos têm ideias que primeiro se corporificam em planos e cálculos antes que essas ideias se convertam em pontes e caminhos; seu pai participava do mundo dos matemáticos, dos músicos, poetas, dramaturgos, físicos, cujas criações eram vertidas em trabalhos escritos ${ }^{287}$.

$\mathrm{O}$ desejo de hacer papeles também tem a ver com a imagem assustadora de Lassale e da jocosa, mas realista, frase do protagonista de A carteira de meu tio ${ }^{288}$, no sentido de pressupor que ainda há muita gente estranha às noções constitucionais de Democracia e de República que engrossa a fila daqueles que pensam como ele. Ou seja, de que "a Constituição contém palavras mortas".

Enfim, depois de expedientes imperiais e de regimes não-democráticos, o princípio de impessoalidade é uma aposta democrática na capacidade de o Estado e a Sociedade (re)construírem juntos, em diálogo adequado, o nosso presente, nossa "vida futura". E sabemos que ninguém faz nada sozinho, tampouco da noite para o dia!

${ }^{287}$ GORDILLO, Agustín. El Metodo em Derecho - Aprender, enseñar, escribir, crear, hacer. Madri: Civitas Ediciones, 1988. p. 24. (tradução nossa)..

${ }^{288}$ MACEDO, José Manuel de. A carteira de meu tio. Introdução, posfácio e notas de Fábio Bortolazzo Pinto. Porto Alegre: L\&PM, 2010. 


\section{REFERÊNCIAS}

ABBAGNANO, Nicola. Dicionário de Filosofia. Alfredo Bosi (Trad. e rev. da $1^{\text {a }}$ ed. Brás. Ivone Castilho Benedetti (revisão da tradução e tradução dos novos textos). $6^{a}$ ed. São Paulo: WFM Martins Fontes, 2012.

ALEJANDRO NIETO. Crítica de la Razón Jurídica. Madrid: Editorial Trotta, 2007.

. El Desgobierno de lo público. Madrid: Editorial Ariel, 2008.

ALMEIDA, Fernando Dias Menezes de. Princípios de direito administrativo: legalidade, segurança jurídica, impessoalidade, publicidade, motivação, eficiência, moralidade, razoabilidade, interesse público. In MARRARA, Tiago (org). . São Paulo Atlas, 2012.

ALMEIDA, Napoleão Mendes de. Dicionário de Questões Vernáculas. $4^{a}$ ed. São Paulo: Ática, 1998.

AMARAL, Antonio Carlos Cintra do. Teoria do Ato Administrativo - prefácio de Celso Antônio Bandeira de Mello. Belo Horizonte: Fórum, 2008.

AMARAL, Diogo Freitas do. História do Pensamento Político Ocidental. Coimbra: Almedina, 2011.

ANDRADE, Carlos Drummond de. Poesia completa e prosa. $4^{\mathrm{a}}$ ed. Petrópolis: Nova Aguilar, 1977.

ANDRADE, Flávia Cristina Moura de. Direito Administrativo. $2^{\mathrm{a}}$ ed. São Paulo: Premier Máxima, 2008.

ANTUNES, Luís Filipe Colaço. O Direito Administrativo sem Estado: crise ou fim de um paradigma? Coimbra: Coimbra Editora, 2008.

ARAGÃO, Alexandre Santos. Curso de Direito Administrativo. Rio de Janeiro: Forense, 2012.

ARAÚJO, Edmir Netto de. Curso de Direito Administrativo. $3^{\mathrm{a}}$ ed. revista, ampliada e atualizada. São Paulo: Saraiva, 2007.

ARENDT, Hannah. Responsabilidade e Julgamento. Edição Jerome Kohn, revisão técnica Bethânia Assy e André Duarte, tradução de Rosaura Einchenberg. São Paulo: Companhia das Letras, 2004.

ÁVILA, Ana Paula Oliveira. O princípio da impessoalidade da administração pública: para uma administração imparcial. Rio de Janeiro: Renovar, 2004.

ÁVILA, Humberto. Teoria dos princípios: da definição à aplicação dos princípios jurídicos. $6^{\mathrm{a}}$ edição revista e ampliada. São Paulo: Malheiros, 2006. 
BANDEIRA DE MELLO, Celso Antônio. Curso de Direito Administrativo. $21^{\mathrm{a}}$ ed. revista e atualizada até a Emenda Constitucional 52, de 8.3006. São Paulo: Malheiros, 2006.

BARROS, Gessner P. Pompêo de. Princípios de Administração Pública. $2^{a}$ edição. Rio de Janeiro: Gráfica Editôra Aurora, 1959.

BARROSO, Luís Roberto. Curso de direito constitucional contemporâneo: os conceitos fundamentais e a construção do novo modelo. São Paulo: Saraiva, 2009.

(org.). A reconstrução democrática do direito público no Brasil. Rio de Janeiro: Renovar, 2007.

BATISTA JÚNIOR, Onofre Alves. Transações Administrativas: um contributo ao estudo do contrato administrativo como mecanismo de prevenção e terminação de litígios e como alternativa á atuação administrativa autoritária, no contexto de uma administração pública mais democrática. São Paulo: Quartier Latin, 2007.

BAPTISTA, Patrícia. Invalidação dos atos administrativos e devido processo legal: Limites Constitucionais á autotutela administrativa: o dever de observância do contraditório e da ampla defesa antes da anulação de um ato administrativo ilegal e seus parâmetros. IN BARROSO, Luís Roberto (org.). A reconstrução democrática do direito público no Brasil. Rio de Janeiro: Renovar, 2007.

BAUMAN, Zygmunt. Vida Líquida. Carlos Alberto Medeiros (Trad.). 2a ed. rev. Rio de Janeiro: Zahar, 2009.

BEZERRA FILHO, Aluizio. Lei de improbidade administrativa. Curitiba: Juruá, 2006.

BINENBOJM, Gustavo. Uma Teoria do direitos administrativo: direitos fundamentais, democracia e constitucionalização. $2^{\mathrm{a}}$ ed. rev. e atual. Rio de Janeiro: Renovar, 2008.

.Novos paradigmas do Direto Administrativo - A Constitucionalização do Direito Administrativo no Brasil: um inventário de avanços e retrocessos. IN BARROSO, Luis Roberto. A reconstrução democrática do direito público no Brasil. Rio de Janeiro: Renovar, 2007.

BOBBIO, Norberto. A era dos direitos. Carlos Nelson Coutinho (Trad.) e apresentação de Celso Lafer. Rio de Janeiro: Elsevier, 2004.

BORGES, Jorge Luis. Nuestro Pobre Individualismo. Inquisiciones/Outras Inquisiciones. Buenos Aires: Debolsillo, 2012.

BRAIBANT, Guy; Nicole QUESTIAUX, Nicole; WIENER, Celine. Le controle de l'administration et la protection des citoyens, Étude comparative. Paris: Éditions Cujas, 1973. (tradução nossa).

BUENO, José Antônio Pimenta, Marquês de São Vicente. Direito Público brasileiro e análise da Constituição do Império apud KUGELMAS, Eduardo (organização e introdução). José Antônio Pimenta Bueno, Marquês de São Vicente. São Paulo: Ed. 34, 2002. 
BULOS, Uadi Lammêgo. Curso de Direito Constitucional. $2^{\mathrm{a}}$ ed. revista e atualizada de acordo com a Emenda Constitucional n. 56/2007. São Paulo: Saraiva, 2008.

BURDEAU, Georges. O Estado. Maria Ermantina de Almeida Prado Galvão (Trad.). São Paulo: Martins Fontes, 2005.

CAMPOS, Paulo Mendes. O mais estranho dos países: crônicas e perfis. Seleção e apresentação de Flávio Pinheiro; posfácio de Sérgio Augusto. São Paulo: Companhia das Letras, 2013.

CANOTILHO, J. J. Gomes. Direito Constitucional e Teoria da Constituição. $7^{\mathrm{a}}$ edição. Coimbra: Edições Almedina, 2003.

CARNAP, Rudolf. Fundamentos da lógica e da matemática apud MARCONDES, Danilo. A pragmática na filosofia contemporânea. Rio de Janeiro: Jorge Zahar Ed., 2005.

CARVALHO, Fábio Lins de Lessa. O princípio da impessoalidade nas licitações. Maceió: EDUFAL, 2005.

CARVALHO FILHO, José dos Santos. Manual de Direito Administrativo. $25^{\mathrm{a}}$ ed. ampliada e atualizada até 03.01.2012. Rio de Janeiro: Atlas, 2012.

. Manual de Direito Administrativo. $18^{\mathrm{a}}$ ed. ampliada e atualizada até 30.06.2007. Rio de Janeiro: Lumen Juris, 2007.

CASSAGNE, Juan Carlos. Curso de Derecho Administrativo. $10^{\mathrm{a}}$ edición actualizada y ampliada. Buenos Aires: La Ley, 2011. p. 66-70. T. 1.

El acto administrativo. Buenos Aires: La Ley, 2012.

CASTRO, Carlos Roberto Siqueira. Dignidade da pessoa humana: o princípio dos princípios constitucionais. In Estudos de Direito Público em homenagem a Celso Antônio Bandeira de Melo. In FIGUEIREDO, Marcelo; PONTES FILHO, Valmir (orgs).

São Paulo: Malheiros, 2006.

CASTRO, José Nilo de. Direito Municipal Positivo. $6^{a}$ ed. revisada e atualizada. Belo Horizonte: Del Rey, 2006.

CAVALCANTE, Temístocles Brandão. Tratado de direito administrativo. Volume I. $3^{\mathrm{a}}$ ed. Teoria Geral do Direito Administrativo - Atos e Contratos Administrativos responsabilidade do Estado. Rio de Janeiro: Livraria Freitas Bastos, 1955.

CEGALLA, Domingos Paschoal. Novíssima Gramática da Língua Portuguesa. São Paulo: Companhia Editora Nacional,1992.

CHAUI, Marilena. Convite à Filosofia. 13a edição. São Paulo: Ática, ano??

COMTE-SPONVILlE, André. Dicionário Filosófico. Eduardo Brandão (Trad.). São Paulo: Martins Fontes, 2003. 
COSTA, Cláudio. Filosofia da linguagem. Rio de Janeiro: Zahar, 2002. pp. 38-39. (Filosofia passo a passo, v. 5).

COUTO, Jorge. A Construção do Brasil. Lisboa: Edições Cosmos, 1995.

CRETELLA JÚNIOR, J. Tratado de direito Administrativo: teoria do direito administrativo. $2^{\mathrm{a}}$ ed. atualizada. Rio de Janeiro: Forense, 2002.

Elementos de Direito Constitucional. $4^{\mathrm{a}}$ ed. revista, atualizada e ampliada. São Paulo: Editora Revista dos Tribunais, 2000.

Curso de Direito Administrativo de acordo com a Constituição de 1998. $11^{\mathrm{a}} \mathrm{ed.}$ revista e atualizada, Rio de Janeiro: Forense, 1991.

CUNHA, José Auri. Filosofia - iniciação à investigação filosófica - prefácio de Celso Favaretto. São Paulo: Atual Editora, 1992.

CUNHA JÚNIOR, Dirley da. Curso de Direito Administrativo. $12^{\mathrm{a}}$ ed. revista, ampliada e atualizada. Bahia: JusPODIVM, 2013.

CUNHA, Sérgio Sérvulo da. Princípios constitucionais. São Paulo: Saraiva, 2006.

DALLARI, Dalmo de Abreu. Elementos de teoria geral do Estado. $26^{\mathrm{a}}$ ed. São Paulo: Saraiva, 2007.

DICCIONARIO DE SINÓNIMOS ANTÓNIMOS E IDEAS AFINES - Larousse . Mexico, 2008..

DICIONÁRIO ESCOLAR DA LÍNGUA PORTUGUESA. Academia Brasileira de Letras. $2^{a}$ ed. São Paulo: Companhia Editora Nacional, 2008.

DICIONÁRIO FILOSÓFICO. Eduardo Brandão (Trad.). São Paulo: Martins Fontes, 2003.

DICIONÁRIO HOUAISS DA LÍNGUA PORTUGUESA.Rio de janeiro: Objetiva, 2009.

DINAMARCO, Cândido Rangel. Fundamentos do processo civil moderno. $4^{\mathrm{a}}$ ed. revisão e atualização de Antônio Rulli Neto. São Paulo: Malheiros, 2001. Tomo 1.

DI PIETRO, Maria Sylvia Zanella. Direito Administrativo. 25ª ed. São Paulo: Atlas, 2012. Direito Administrativo. 20ª ed. São Paulo: Atlas, 2007.

Introdução: Existe um novo Direito Administrativo? In DI PIETRO, Maria Sylvia $\overline{\text { Zanella}}$; RIBEIRO, Carlos Vinícius Alves (coords). Supremacia do interesse público e outros temas relevantes do direto administrativo. São Paulo: Atlas, 2010.

DROMI, Roberto. Derecho Administrativo. $12^{\mathrm{a}}$ ed. atualizada. Buenos Aires, Madrid/México: Ciudad Argentina: Hispania Libros, 2009. 
DUARTE, David. Procedimentalização, Participação e Fundamentação: para uma concretização do princípio da imparcialidade administrativa como parâmetro decisório. Coimbra: Livraria Almedina, 1996.

DUROZOI, G; ROUSSEL, A. Dicionário de filosofia. Maria de Fátima de Sá Correia (Trad.). Coimbra: Porto, 2000.

ECO, Humberto. Como se faz uma tese. Gilson Cesar Cardoso de Souza (Trad.). São Paulo: Perspectiva, 2006.

ENTERRÍA, Eduardo Garcia de. As transformações da justiça administrativa: da sindicabilidade restrita à plenitude jurisprudencial. Uma mudança de paradigma? Fábio Medina Osório (Trad.); apresentação de Diogo de Figueiredo Moreira Neto. Belo Horizonte: Fórum, 2010. ), p. 93-94. (Coleção Fórum Brasil-Espanha de Direito Público; 1.

ESTORNINHO, Maria João. Requiem pelo Contrato Administrativo. Coimbra: Almedina, 2003.

FAGUNDES, Miguel Seabra. Controle dos Atos Administrativos pelo Poder Judiciário. $8^{\mathrm{a}}$ edição atualizada até 2010, por Gustavo Binenbojm. Rio de Janeiro:Forense, 2010.

FALLA, Garrido. Tratado de Derecho Administrativo. Vol. 1, Parte Geral. 15ª ed. Madrid: Editorial Tecnos, 2010.

FAORO, Raymundo. Os donos do poder: formação do patronato político brasileiro. $3^{\mathrm{a}}$ ed. rev. São Paulo: Globo, 2001.

FERREIRA, Gabriela Nunes. Um enigma chamado Brasil: 29 intérpretes e um país. In BOTELHO, André; SCHWARCZ, Lilia Moritz (orgs). . São Paulo: Companhia das Letras, 2009.

FIGUEIREDO, Lúcia Valle. Curso de direito administrativo. $8^{\mathrm{a}}$ ed. revista, ampliada e atualizada até a emenda Constitucional 52/2006. São Paulo: Malheiros, 2006.

FREITAS, Juarez de. O Controle dos Atos Administrativos e os princípios fundamentais. $4^{\mathrm{a}}$ ed. refundida e ampliada. São Paulo: Malheiros, 2009. p. 82.

GARCIA, Emerson; ALVES, Rogério Pacheco. Improbidade administrativa. $2^{\mathrm{a}}$ ed. revista e ampliada. Rio de Janeiro: Lumen Juris, 2004.

GASPARINI, Diógenes. Direito Administrativo. $12^{\mathrm{a}}$ edição revista e atualizada. São Paulo: Saraiva, 2007.

GIACOMOZZI, Gilio et al. Dicionário de Gramática. São Paulo: FDT, 2004.

GORDILLO, Agustín. Tratado de Derecho Administrativo. Prólogo de Jorge A. Sáenz Tomo I, Parte Geral. 10ª ed. Buenos Aires: Fundación de Derecho Administrativo, 2009.

La administración paralela. Madrid: Cuadernos Civitas, 2011. 
El Metodo em Derecho - Aprender, enseñar, escribir, crear, hacer. Madri: Civitas Ediciones, 1988.

GRANDE DICIONÁRIO SACCONI DA LÍNGUA PORTUGUESA. comentado, crítico e enciclopédico. São Paulo: Nova Geração, 2010.

GUIMARÃES, Bernardo Strobel. Princípios de direito administrativo: legalidade, segurança jurídica, impessoalidade, publicidade, motivação, eficiência, moralidade, razoabilidade, interesse público. In MARRARA, Tiago (org). __. São Paulo Atlas, 2012.

GRAU, Eros Roberto. Porque tenho medo dos juízes (a interpretação/aplicação do direito e dos princípios). $6^{a}$ edição refundida do ensaio e discurso sobre a interpretação/aplicação do direito. São Paulo: Malheiros, 2013.

$O$ direito posto e o direito pressuposto. $8^{\text {a }}$. ed. revista e ampliada. São Paulo: Malheiros, 2011.

GUEDES, Demian. Processo Administrativo e democracia - prefácio de Leonardo Greco; apresentação de Marcos Juruena Villela Souto. Belo Horizonte: Fórum, 2007.

HARGER, Marcelo. Princípios Constitucionais do Processo Administrativo. $2^{\mathrm{a}}$ ed. revista e atualizada. Rio de Janeiro: Forense, 2008.

HOLANDA, Sério Buarque de. Raízes do Brasil. 26a ed. São Paulo: Companhia das Letras, 1995.

JÈZE, Gaston. Principios generales del derecho administrativo. Carlos García Oviedo (Trad.). Bogotá: Axel Editores, 2010.

JOHNSON, Allan G. Dicionário de Sociologia: guia prática da linguagem sociológica. Ruy Jungmann (Trad); consultoria Renato Lessa. Rio de Janeiro: Zahar, 1997.

JUSTEN FILHO, Marçal. Curso de Direito Administrativo. $8^{\mathrm{a}}$ ed. revista, ampliada e atualizada. Belo Horizonte: FORUM, 2012.

. Direito Administrativo e seus novos paradigmas. In ARAGÃO, Alexandre Santos de; MARQUES NETO, Floriano de Azevedo (coords). Belo Horizonte: Fórum, 2008.

KUGELMAS, Eduardo (organização e introdução). José Antônio Pimenta Bueno, Marquês de São Vicente. São Paulo: Ed. 34, 2002.

LASSALE, Ferdinand. O que é a Constituição? Leme: CL EDIJUR, 2012.

LIMA, Rui Cirne. Princípios de Direito Administrativo. $7^{\mathrm{a}}$ ed. revista e reelaborada por Paulo Alberto Pasqualini. São Paulo: Malheiros, 2007. 
LUHMANN, Niklas. Legitimação pelo procedimento. Maria da Conceição Córte-Real (Trad.). Tércio Sampaio Ferraz Jr. (apresentação).Brasília: Editora Universidade de Brasília, 1980. (Coleção Pensamento Político 15).

MARCONDES, Danilo. A pragmática na filosofia contemporânea. Rio de Janeiro: Jorge Zahar Ed., 2005. (Filosofia passo a passo, v. 59).

MARINELA, Fernanda. Direito Administrativo. $7^{\text {a }}$ ed. Niterói: Impetus, 2013.

MARQUES NETO, Floriano de Azevedo. A superação do ato administrativo autista. In MEDAUAR, Odete; SCHIRATO, Vitor Rhein (orgs). Os caminhos do ato administrativo. São Paulo: Revista dos Tribunais, 2012.

MAZZA, Alexandre. Manual de Direito Administrativo. $3^{\text {a }}$ ed. São Paulo: Saraiva, 2013.

MEDAUAR, Odete. Direito Administrativo Moderno. $15^{\mathrm{a}}$ ed, revista atualizada e ampliada. São Paulo: Revista dos Tribunais, 2011.

. Controle da Administração Pública. $2^{\mathrm{a}}$ ed. rev. atual e ampl. São Paulo: Editora Revista dos Tribunais, 2012.

. Direito Administrativo Moderno. $15^{\mathrm{a}}$ ed. revista, atual.e ampl. São Paulo: Revista dos Tribunais, 2011.

. A processualidade no direito administrativo. $2^{\mathrm{a}}$ ed. revista, atualizada e ampliada. São Paulo: Editora Revista dos Tribunais, 2008. 1992.

. O direito administrativo em evolução. São Paulo: Editora Revista dos Tribunais, . Ato administrativo: origem, concepções, abrangência. In MEDAUAR, Odete; SCHIRATO, Vitor Rhein (coords). Os caminhos do ato administrativo. São Paulo: Revista dos Tribunais, 2012.

MEDAUAR, Odete; SCHIRATO, Vitor Rhein (coords). Os caminhos do ato administrativo. São Paulo: Revista dos Tribunais, 2012.

Tribunais, 2010 .

. (orgs). Atuais Rumos do Processo Administrativo. São Paulo: Revista dos

MEIRELLES, Hely Lopes. Direito Administrativo Brasileiro. $39^{\mathrm{a}}$ ed. Atualizada por Délcio Balestero Aleixo e José Emmanuel Burle Filho. São Paulo: Malheiros, 2013.

. Direito Administrativo Brasileiro. $21^{\mathrm{a}}$ ed. Atualizada por Eurico de Andrade Azevedo, Délcio Balestero Aleixo e José Emmanuel Burle Filho. São Paulo: Malheiros, 1996.

MELO, Cristina Andrade. O princípio da impessoalidade - Audiência pública como contributo à imparcialidade na atuação estatal. In BATISTA JÚNIOR, Onofre Alves; CASTRO, Sérgio Pessoa de Paula. (coords.). Tendências e perspectivas do Direito Administração: uma visão da escola mineira. Belo Horizonte: Fórum, 2012. 
MELLO, Osvaldo Aranha Bandeira de. Princípios Gerais de Direito Administrativo. $3^{\mathrm{a}}$ ed. $2^{a}$ tiragem. São Paulo: Malheiros Editores, 2010, p. 142. Vol I.

MENDES, Gilmar Ferreira; COELHO, Inocêncio Mártires; BRANCO, Paulo Gustavo Gonet. Curso de Direito Constitucional. $2^{\mathrm{a}}$ ed., revisada e atualizada. São Paulo: Saraiva, 2008.

MIRANDA, Jorge. Teoria do Estado e da Constituição. Coimbra: Editora Coimbra, 2002.

MOREIRA, Egon Bockmann. Processo Administrativo - princípios constitucionais e a Lei n. 9.784/1999. São Paulo: Malheiros, 2010.

MOREIRA NETO, Diogo de Figueiredo. Curso de Direito Administrativo: parte introdutória, parte geral e parte especial. Rio de Janeiro: Forense, 2009.

NEVES, Marcelo. A constitucionalização simbólica. $3^{\mathrm{a}}$ ed. São Paulo: WFW Martins Fontes, 2011.

NOGUEIRA, Marco Aurélio. O futuro da democracia. São Paulo: Paz e Terra, 2000.

NOHARA, Irene Patrícia. Direito Administrativo. São Paulo: Atlas, 2011.

NOVO AURÉLIO - O Dicionário da Língua Portuguesa Século XXI. $3^{\mathrm{a}}$ ed. Rio de Janeiro: Nova Fronteira, 1999.

NOVO AURÉLIO SÉCULO XXI - Dicionário da língua Portuguesa. $3^{\text {a }}$ edição, totalmente revista e ampliada. Rio de Janeiro: Nova Fronteira, 1999.

OLIVEIRA, Rafael Carvalho Rezende. Princípios do Direito Administrativo. Rio de Janeiro: Lumen Juris, 2011.

OSÓRIO, Fábio Medina. Teoria da improbidade administrativa: má gestão pública; corrupção; ineficiência - prefácio de Eduardo Garcia de Enterría. $3^{\text {a }}$ ed.São Paulo: Editora Revista dos Tribunais, 2013.

PAZZAGLINI FILHO, Marino. Princípios constitucionais regulares da administração pública: agentes públicos - discricionariedade administrativa, extensão da atuação do Ministério Público e do controle do poder judiciário. $2^{a}$ ed.São Paulo: Atlas, 2003.

PERELMAN, Chaïm. Lógica jurídica: nova retórica. Vergínia K. Pupi (Trad.). Maria Ermantina de Almeida Prado Galvão (rev. trad.). Revista Técnica Gildo Sá Leitão Rios. $2^{\mathrm{a}}$ ed. São Paulo: Martins Fontes, 2004.

PESTANA, Márcio. Direito Administrativo Brasileiro. $3^{\mathrm{a}}$ ed. Rio de Janeiro: Elsevier, 2012.

RAMOS, Dora Maria de Oliveira. Princípios de direito administrativo: legalidade, segurança jurídica, impessoalidade, publicidade, motivação, eficiência, moralidade, razoabilidade, interesse público. In MARRARA, Tiago (org.). São Paulo: Atlas, 2012. 
RAMOS, Alberto Guerreiro. Administração e Contexto Brasileiro: esboço de uma teoria geral da administração. $2^{a}$ ed. Rio de janeiro: Ed. da Fundação Getúlio Vargas, 1983.

REALE, Miguel. Questões de Direito Público. São Paulo: Saraiva, 1997.

RIBEIRO, Maria Teresa de Melo. O Princípio da Imparcialidade da Administração Pública. Coimbra: Livraria Almedina, 1996.

RIVERO, Jean. Curso de Direito Administrativo Comparado. $2^{\mathrm{a}}$ ed. J. Crettela Jr (Trad.). São Paulo: RT, 2004.

Direito Administrativo. Doutor Rogério Ehrhardt Soares (Trad.). Coimbra: Livraria Almedina, 1981.

ROCHA, Cármen Lúcia Antunes. Princípios constitucionais da administração pública. Belo Horizonte: Del Rey, 1994.

ROSA, Renata Porto de Adri. Princípio de Impessoalidade. In et al - prefácio de Lúcia Valle Figueiredo. Princípios Informadores do Direito Administrativo. São Paulo: Editora NDJ, 1997.

SILVA, José Afonso da. Curso de Direito Constitucional Positivo. $22^{\mathrm{a}}$ ed. revista e atualizada nos termos da Reforma Constitucional - até a Emenda Constitucional n. 39, de 19.12.2002. São Paulo: Malheiros, 2003.

2011.

O Constitucionalismo Brasileiro - evolução institucional. São Paulo: Malheiros,

SILVA, Vasco Manuel Pascoal Dias Pereira da. Em Busca do Acto Administrativo Perdido. Coimbra: Coimbra, 2003.

SOUSA, Marcelo Rebelo de; MATOS, André Salgado de. Direito Administrativo Geral Introdução e princípios fundamentais. $3^{\mathrm{a}}$ ed. Portugal: D. Quixote, 2010. p. 64. Tomo 1.

STRECK, Lênio Luiz. Verdade e Consenso: constituição, hermenêutica e teorias discursivas. $4^{\text {a }}$ ed. São Paulo: Saraiva, 2011.

SUNDELD, Carlos Ari. Fundamentos de Direito Público. $4^{\mathrm{a}}$ ed. São Paulo:Malheiros, 2006.

. Direito Administrativo para os céticos. São Paulo: Malheiros, 2012.

SUPIOT, Alain. Homo juridicus: ensaio sobre a função antropológica do Direito. Maria Ermantina de Almeida Prado Galvão (Trad.). São Paulo: WMF Martins fontes, 2007.

VIEIRA, Evelise Pedroso Teixeira Prado. Direito Administrativo. São Paulo: Verbatim, 2011. 
ZAGO, Lívia Maria Armentano Koenigstein. O princípio da impessoalidade. Rio de Janeiro: Renovar, 2001.

URUGUAI, Visconde de. Ensaio sôbre o Direito Administrativo. Themístocles Brandão Cavalcanti (apres.). Rio de Janeiro: Serviço de Documentação do Ministério da Justiça e negócios Interiores, 1960. 